ELISA CAMPOS MACHADO

\title{
BIBLIOTECAS COMUNITÁRIAS COMO PRÁTICA SOCIAL NO BRASIL
}

Tese apresentada ao Programa de PósGraduação em Ciência da Informação, Área de Concentração Cultura e Informação, Linha de Pesquisa: Acesso à Informação, da Escola de Comunicações e Artes da Universidade de São Paulo, como exigência parcial para obtenção do Título de Doutor em Ciência da Informação sob a orientação do Prof. Dr. Waldomiro de Castro Santos Vergueiro

São Paulo

2008 


\section{BIBLIOTECAS COMUNITÁRIAS COMO PRÁTICA SOCIAL NO BRASIL}

Tese defendida em __ de___ de 200_.

Comissão Julgadora

1.

Orientador: Prof. Dr. Waldomiro de Castro Santos Vergueiro

2.

3.

4.

5. 


\section{AGRADECIMENTOS}

Ao professor Waldomiro Vergueiro, pela sua firme, segura e tranqüila orientação, sempre me ajudando a encontrar os melhores caminhos na construção desta pesquisa.

À professora Maria Christina Barbosa de Almeida, pelo carinho e disposição em refletir comigo sobre este tema.

Ao professor Arturo Martin Veja pelo incentivo no início desta pesquisa.

Ao companheiro de pesquisa, professor Geraldo Prado, pelo apoio e colaboração, no desenvolvimento deste trabalho.

Às queridas amigas e companheiras de trabalho, Ruth Negrini e Daniela Greeb, pelas leituras, reflexões e contribuições que sempre me ajudaram a ampliar o meu olhar sobre o tema.

À Cintia Carvalho, da A Cor da Letra, pelo carinho e disposição em colaborar em todas as etapas desta pesquisa.

À Daniela Weiers, Joana Arari e Sylvia Guimarães, da Associação Vaga Lume, que se colocaram sempre abertas e à disposição para colaborar com esta pesquisa.

À Lara Elena Ramos Simielli e Liane Codespoti Muniz, do Instituto Ecofuturo, que me atenderam com prontidão e forneceram ricas informações para esta pesquisa.

Aos professores Marcos Miranda, Maria Teresa Wiltgen Tavares da Costa Fontoura, Simone Weitzel e a todos os professores e funcionários da Escola de Biblioteconomia da UNIRIO, pelo constante apoio e incentivo.

À professora Maria Tereza Reis Mendes, pela colaboração na normalização e na forma deste documento.

À Fernanda Carvalho Reis, pelas leituras e contribuições.

Aos alunos dos cursos que ministrei na UNIRIO, que me acompanharam e torceram por mim durante todo esse tempo.

Ao professor Cláudio Marcondes pelo carinho, amizade e incentivo.

Ao arquiteto Rui Ohtake e ao professor José Castilho Marques Neto, por terem me apresentado o Programa Identidade Cultural de Heliópolis. 
A todos aqueles que participaram de alguma maneira, me inspirando e me ajudando a construir esse trabalho: Adevaldo de Souza; Ana Margareth do Nascimento Amorim; Ana Maria Cabral da Gama; Carlos Magno Faccion Junior; Carlos Magno Martins Farias; Carolina Marques Paula; Célia Barbosa de Sá; Cintia Abreu; Devanir Amâncio; Douglas Mendes; Edson Lima (Dunga); Everaldo da Silva; Fabiana Pitanga da Silva; Fabiana Vilar; Fabio Munhoz; Felipe Garcia; Hilda Márcia Albino Sebastião; Jairzinho Rabelo; Joana Albino da Silva; José Augusto de Oliveira; José Renato Galvão; Joseni Ferreira Amorim; Luiz Amorim; Madalena Moniz Garcia Franzon; Márcia Licá; Maria Alice Setti (Lili); Maria Nilda de Mota Almeida (Dinha); Marinho Soares da Silva; Marli Martins; Paulo Aurélio da Silva; Raimunda Olinda Maciel Brabo; Renata Ferreira Alves; Renato Nunes da Silva (Bisturi); Renato Reis Nunes; Roberta Maria da Conceição; Rômulo Morishita; Sara Sacramento; Sérgio da Silva Pereira Macuxi; Sheila Soares; Sinval Pereira dos Santos; Tânia Maria de Jesus; Terezinha Puppin; Vanessa Pantanni Vannucci; Weber Lopes.

Ao meu querido filho Pedro, pela ajuda no tratamento das fotos, pelas inúmeras leituras críticas que muito me ajudaram e especialmente pelo carinho e incentivo que sempre me deu para realizar este trabalho.

À minha mãe Morena e às minhas queridas amigas Lú e Nadja pelo apoio, paciência e carinho durante todo o tempo em que estive envolvida nesta pesquisa.

Ao meu marido Otávio, pelo seu companheirismo, incentivo e apoio ao longo de toda a pesquisa. 


\section{RESUMO}

A pesquisa aborda a biblioteca comunitária como prática social, no Brasil. Tem por objetivo principal apontar políticas públicas para o fortalecimento e ampliação dessas iniciativas. Para isso, foi necessário proceder à análise da biblioteca comunitária como espaço de articulação local, seus atores, sua organização e o uso da informação nesse contexto. Partindo do conceito de "comunidade", apresentamos uma reflexão sobre as práticas sociais, os processos participativos e a relação do Estado na construção de políticas públicas para apoiar essas experiências. Discutimos o emprego do termo pela sociedade e pela área acadêmica, analisando as semelhanças e diferenças entre a biblioteca comunitária e a biblioteca pública e popular. Optamos pela metodologia qualitativa com objetivos exploratórios e resultados descritivos e analíticos. Levantamos 350 experiências no território nacional e selecionamos 29 para compor o universo da pesquisa. Lançando mão das técnicas de entrevista e observação, pudemos confirmar que o motivo principal para a criação desses projetos é a carência de bibliotecas públicas e escolares no país, o que leva a sociedade a buscar caminhos para enfrentar o problema de acesso à informação, à leitura e ao livro. A partir das experiências analisadas, foi possível perceber que, quanto mais participativa é a sua gestão, maior é a possibilidade da biblioteca transformar-se num espaço estratégico para a implantação de políticas de integração social. Apontamos como princípios básicos para a implantação de políticas para esses espaços o respeito à diversidade e pluralidade cultural, assim como a valorização do espaço público e dos processos participativos. Defendemos a consolidação do Sistema Nacional de Bibliotecas Públicas como agência responsável pela implementação, monitoramento e avaliação das políticas públicas para apoiar as bibliotecas comunitárias.

Palavras-chave: Biblioteca Comunitária. Biblioteca Pública. Políticas Públicas para Bibliotecas. 


\begin{abstract}
The research focuses on the community library as social practice in Brazil. Its main objective is to discuss possible policies to strength and broaden these experiences. To accomplish these objectives performing the analysis of the community library as a space for local commitment, its participants, the organization and the use of information in this context became necessary. Starting from the concept of "community", we deal with the social practice, the participation process and the relationship with the State for the construction of public policies to support these experiences. We discuss the use of the term by the society and academic field, analyzing the similarities and differences among community, public and popular library. We decided for the qualitative methodology with an exploratory objective survey, aiming to descriptive and analytical results. We investigated 350 experiences in Brazil and selected 29 to compose the research universe. By making use of interviews and observation techniques, it was possible to confirm that the main reason for the creation of these projects is the lack of public and school libraries in the country, which leads society to find ways to face the problems of the information, reading and book access. According to the analyzed experiences, we concluded that the more participative is the administration, the more possibility of the library becoming a strategic space, capable of implementing the social integration policies, increases. We point out, the respect to cultural diversity and plurality, as well as the valorization of the public space and participative process, as main principles to establish policies for these spaces. We support the consolidation of the Sistema Nacional de Bibliotecas Públicas, as the responsible agency for implementing, monitoring and evaluating of public policies to give support to the community libraries.
\end{abstract}

Keywords: Community Library. Public Library. Public Polices for Libraries. 


\section{LISTA DE FIGURAS}

Figura 1-2 Cabeçalho de assunto da LC ............................................ 56

Figura 3-4 Cabeçalho de assunto da BN ................................................ 57

Figura $5 \quad$ Luiz Amorim no Açougue T-Bone ........................................ 100

Figura $6 \quad$ Açougue T-Bone ........................................................... 100

Figura 7 Biblioteca Vaga Lume da Comunidade de Santa Tereza ......... 106

Figura 8 Biblioteca Vaga Lume da Comunidade de Bengui .................. 106

Figura 9-11 Biblioteca Comunitária Solano Trindade ............................... 112

Figura 12-13 Biblioteca Comunitária Zumaluma ……................................... 113

Figura 14 Conselho Bibliotecário da Biblioteca Vaga Lume da

Comunidade de Boca da Mata ............................................ 118

Figura 15 Grupo de voluntários da Biblioteca Vaga Lume da

Comunidade de Corre Água do Piririm ................................... 118

Figura 16 Formação de mediadores de leitura na Comunidade de

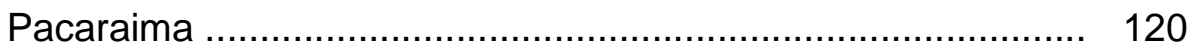

Figura 17 Mediação de leitura na Biblioteca Vaga Lume da Comunidade de Corre Água do Piririm ...................................................... 120

Figura 18-19 Biblioteca Comunitária Ler é Preciso da Coopamare ............... 122

Figura 20-21 Centro Educacional e Cultural Kaffehuset Friele ..................... 125

Figura 22-23 Biblioteca Comunitária de Heliópolis ..................................... 127

Figura 24 Evandro no quarto em que dorme em sua casa-biblioteca ...... 129

Figura 25 Evandro vestido de homem-livro ....................................... 129

Figura 26-28 Biblioteca Comunitária Maria das Neves Prado ..................... 130

Figura 29-31 Parada Cultural T-Bone ................................................... 130

Figura $32 \quad$ Maloca Espaço Cultural .................................................... 139

Figura 33 Biblioteca Comunitária Livro-Pra-Quê-Te-Quero ..................... 139 


\section{LISTA DE QUADROS}

Quadro $1 \quad$ Relação das experiências analisadas …................................ 27

Quadro 2 Quadro comparativo entre Bibliotecas Públicas e Bibliotecas

Comunitárias ….......................................................... 64

Quadro 3 Porcentagem de experiências identificadas por estado

brasileiro .............................................................. 93

Quadro 4 Experiências identificadas em municípios com mais de um milhão de habitantes .................................................... 96

Quadro 5 Relação de experiências com maior nível de participação ....... 116

Quadro $4 \quad$ Universo da pesquisa: 29 experiências analisadas ................. 175 


\section{LISTA DE ABREVIATURAS E SIGLAS}

Abrinq Associação Brasileira dos Fabricantes de Brinquedos

ALA

American Library Association

APB

Associação Paulista de Bibliotecários

AS

See also

$\mathrm{BC}$

Biblioteca comunitária

BNDES Banco Nacional de Desenvolvimento Econômico e Social

$\mathrm{BP}$

Biblioteca pública

BT

Broader Topic

BVL

Biblioteca Vaga Lume

CAESB

Companhia de Saneamento Ambiental do Distrito Federal

CBBD

Congresso Brasileiro de Biblioteconomia e Documentação

CDD

Classificação Decimal de Dewey

$\mathrm{CDHU}$

Companhia de Desenvolvimento Habitacional e Urbano do

Estado de São Paulo

CEASM Centro de Estudos e Ações Solidárias da Maré

CEU Centro Educacional Unificado

CNPC Conselho Nacional de Política Cultural

CNPJ Cadastro Nacional de Pessoa Jurídica

COLE Congresso de Leitura do Brasil

COOPAMARE Cooperativa de Catadores Autônomos de Papel, Papelão, Aparas e Materiais Reaproveitáveis

CPV-Maré Pré-Vestibular Comunitário da Maré

CSLL Câmara Setorial do Livro e da Leitura

EUA Estados Unidos da América

FBN Fundação Biblioteca Nacional

FEBAB Federação Brasileira de Associações de Bibliotecários, Cientistas da Informação e Instituições

FNLIJ Fundação Nacional do Livro Infanto-Juvenil

FUNAP Fundação Prof. Dr. Manoel Pedro Pimentel

FUST Fundo de Universalização de Serviços de Telecomunicações 


\begin{tabular}{ll} 
IBGE & Instituto Brasileiro de Geografia e Estatística \\
IBICT & Instituto Brasileiro de Informação em Ciência e Tecnologia \\
ICE & Instituto de Cidadania Empresarial \\
IDEAC & Instituto Brasileiro de Estudo e Apoio Comunitária \\
IDH & Índice de Desenvolvimento Humano \\
IFLA & International Federation of Library Associations and Institutions \\
INL & Instituto Nacional do Livro \\
LA & Library Association \\
LC & Library of Congress \\
MC & Mestre de cerimônia \\
MID & Mapa da Inclusão Digital \\
Minc & Ministério da Cultura \\
MMA & Ministério do Meio Ambiente \\
MST & Movimento dos Sem Terra \\
MSTC & Movimento dos Sem-Tetos do Centro \\
NT & Narrower Topic \\
OAF & Organização de Auxílio Fraterno \\
ONG & Organização Não Governamental \\
OSCIP & Organizaçães da Sociedade Civil de Interesse Público \\
PMSP & Prefeitura Municipal de São Paulo \\
PNBE & Programa Nacional Bibliotecas nas Escolas \\
PNBEM & Programa Nacional Biblioteca da Escola para o Ensino Médio \\
PNLD & Programa Nacional do Livro Didático \\
PNLL & Plano Nacional do Livro e da Leitura \\
PROLER & Programa Nacional de Incentivo à Leitura \\
PUC-SP & Pontifícia Universidade Católica de São Paulo \\
RT & Related Topic \\
SERPRO/BA & Serviço Federal de Processamento de Dados da Bahia \\
SMC & Secretaria Municipal de Cultura \\
SME & Secretaria Municipal de Educação \\
SNBP & Sistema Nacional de Bibliotecas Públicas \\
SOCINFO & Programa Sociedade da Informação \\
TCC & Trabalho de Conclusão de Curso \\
\hline SNe &
\end{tabular}




$\begin{array}{ll}\text { TE } & \text { Termo Específico } \\ \text { TG } & \text { Termo Genérico } \\ \text { TR } & \text { Termo Relacionado } \\ \text { UERJ } & \text { Universidade do Estado do Rio de Janeiro } \\ \text { UERR } & \text { Universidade Estadual de Roraima } \\ \text { UF } & \text { User For } \\ \text { UFSCar } & \text { Universidade Federal de São Carlos } \\ \text { UNAS } & \text { União de Núcleos, Associações e Sociedades dos Moradores de } \\ & \text { Heliópolis e São João Clímaco } \\ \text { UNESCO } & \text { Organização das Nações Unidades para a Educação, a Ciência e } \\ & \text { a Cultura } \\ \text { UNESP } & \text { Universidade Estadual Paulista } \\ \text { UNIRIO } & \text { Universidade Federal do Estado do Rio de Janeiro } \\ \text { UP } & \text { Usado Por } \\ \text { USP } & \text { Universidade de São Paulo } \\ \text { VAI } & \text { Programa para a Valorização de Iniciativas Culturais } \\ \text { VT } & \text { Ver também }\end{array}$




\section{SUMÁRIO}

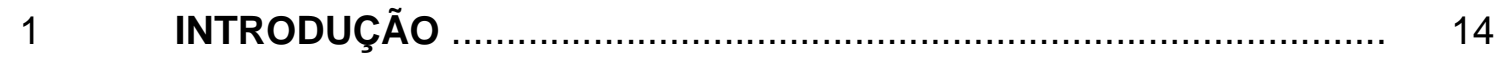

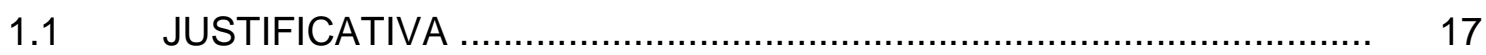

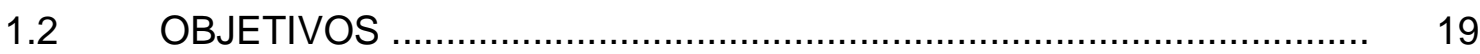

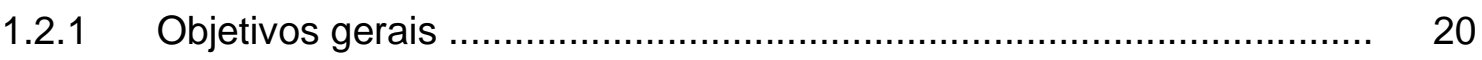

1.2.2 Objetivos específicos ............................................................. 20

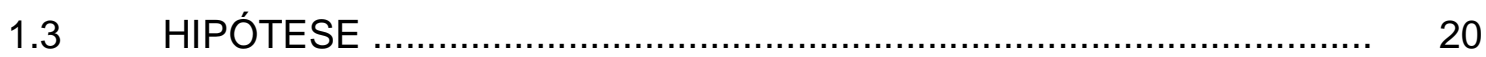

1.4 REFERENCIAL TEÓRICO ….................................................... 21

1.5 PROCEDIMENTOS METODOLÓGICOS ........................................ 23

2 PRÁTICAS SOCIAIS E POLÍTICAS PÚBLICAS NA SOCIEDADE

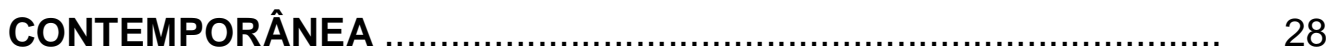

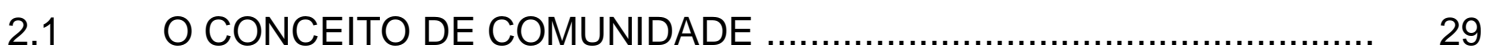

2.2 PRÁTICAS SOCIAIS E PROCESSOS PARTICIPATIVOS .................. 33

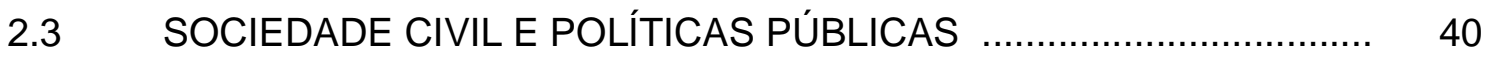

3 BIBLIOTECAS COMUNITÁRIAS ............................................... 49

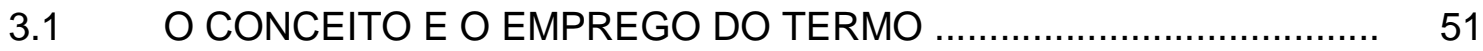

3.2 AS PRÁTICAS SOCIAIS E A BIBLIOTECONOMIA ........................... 65

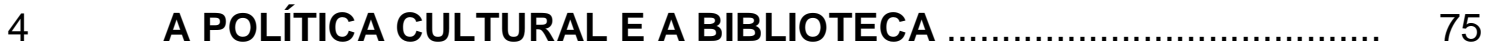

4.1 POLÍTICAS PÚBLICAS NACIONAIS PARA BIBLIOTECAS ................ 78

$4.2 \quad$ POLÍTICAS PÚBLICAS LOCAIS PARA BIBLIOTECAS ..................... 85

5 UM OLHAR PARA A REALIDADE DAS BIBLIOTECAS

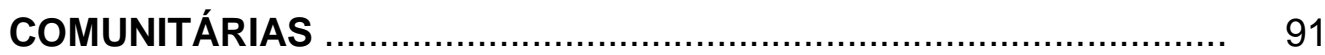

5.1 ANÁLISE DO CONJUNTO DE EXPERIÊNCIAS IDENTIFICADAS ..... 93

5.2 OS MOTIVOS E OS ATORES PRINCIPAIS ................................... 97

5.2.1 Projetos criados a partir de iniciativas individuais ............................ 98

5.2.2 Projetos criados a partir de iniciativas coletivas ................................ 102

5.2.2.1 Projetos criados a partir de iniciativas coletivas externas à comunidade ........................................................................ 102

5.2.2.2 Projetos criados a partir de iniciativas coletivas internas à comunidade ....................................................................... 109

5.3 PARTICIPAÇÃO, ARTICULAÇÃO E SUSTENTABILIDADE ............... 114 
5.3.1 As diferentes formas de entender a participação ................................ 115

5.3.2 As diferentes formas de articulação e sustentabilidade ....................... 124

5.4 ACERVO, INFRA-ESTRUTURA E AÇÕES .................................... 133

5.4.1 Formação, desenvolvimento e tratamento de acervos ....................... 134

5.4.2 Equipamentos e infra-estrutura ................................................... 137

5.4.3 Usuários e atendimento ............................................................... 138

5.4.4 Equipe interna e formação ........................................................ 140

5.4.5 Espaço físico e ambientação ........................................................ 142

5.4.6 Serviços e ação cultural .......................................................... 143

6 BIBLIOTECAS COMUNITÁRIAS: DESAFIO PARA AS POLÍTICAS

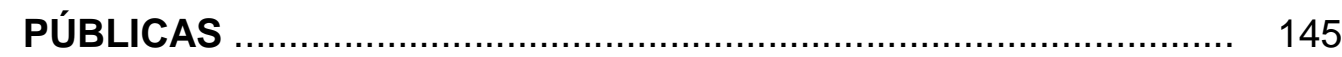

$7 \quad$ CONSIDERAÇÕES FINAIS ....................................................... 158

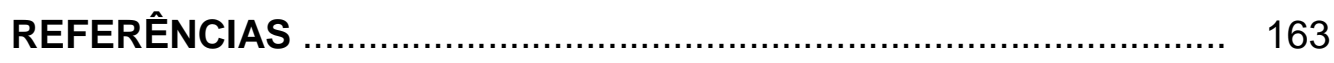

BIBLIOGRAFIA COMPLEMENTAR 173

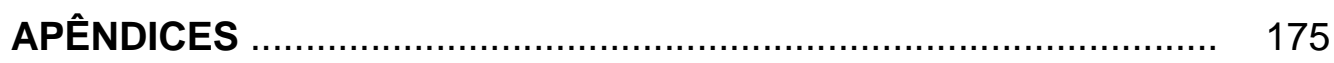

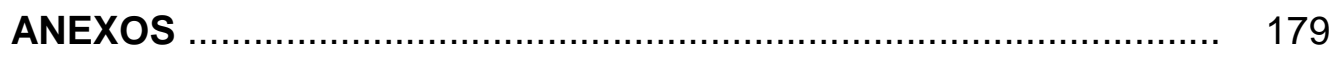




\section{INTRODUÇÃO}

Nos instalamos de maneira segura em nossas teorias e idéias, e estas não têm estrutura para acolher o novo.

Entretanto, o novo brota sem parar.

Edgard Morin

Investigar e refletir sobre a relação entre a biblioteca comunitária e as práticas sociais, só tem sentido se pensarmos esses processos como parte de um contexto. Para tanto, consideramos importante destacar algumas mudanças de valores e comportamento da sociedade contemporânea, pois acreditamos que essas mudanças têm influência significativa na formação de comunidades e de movimentos sociais que levam à criação de projetos que visam atender demandas locais de acesso à leitura, à informação e ao livro. Além disso, essas mesmas mudanças têm impactado sobremaneira as práticas biblioteconômicas.

$\mathrm{Na}$ esfera global, podemos dizer que a sociedade vive uma era de permanente pressão, em que a flexibilidade, a fluidez e a dinamicidade são palavras de ordem, os níveis de segurança são mínimos e os fluxos de informação seguem caminhos de extrema complexidade. É a era denominada por alguns autores como pós-modernidade. (HALL, 2005; COELHO NETO, 2005)

Já na esfera local, essa percepção muda, pois diferentes estados de cultura se sobrepõem, fazendo com que grupos de pessoas e ambientes convivam com as características próprias da pós-modernidade e da modernidade. Segundo Boaventura de Souza Santos (2005, p. 17),

o local é cada vez mais o outro lado do global, e vice-versa, o global é cada vez mais o outro lado do local [...] Nunca foi tão profundo o sentimento de desconexão e de exclusão em relação às transformações que marcam o espaço e o tempo do mundo.

$\mathrm{Na}$ modernidade, os homens e mulheres buscavam o mundo perfeito onde nada deveria estar fora do lugar e os valores e princípios fundamentais estavam pautados na segurança, no equilíbrio, na ordem, na regulamentação e no Estado. A pós-modernidade é marcada pelo desequilíbrio, aceleração, desregulamentação e privatização e também pelo rompimento da linearidade do pensamento e da ação.

No caso da biblioteca, espaço tradicionalmente estático, percebemos conceitos e técnicas seculares caírem por água abaixo em função dessas mudanças. 
O rápido avanço tecnológico no planeta é um forte componente da aceleração nas mudanças pela qual a sociedade e as organizações estão passando. Se, por um lado, a tecnologia apresenta-se como uma ferramenta que minimiza as distâncias, aproxima as pessoas, abrindo novos caminhos, criando oportunidades e gerando qualidade de vida, por outro lado, de forma paradoxal e ambígua, essa mesma tecnologia colabora para ampliar as distâncias entre aquelas pessoas que têm acesso à informação e à tecnologia e aquelas que não o têm, bem como fomenta o individualismo, excluindo aqueles que não participam da sociedade de mercado, num evidente aumento da desigualdade social.

Sem dúvida, a tecnologia é um dos fatores que colaboraram de forma determinante para as mudanças que estamos vivendo; porém, não é só ela. $\mathrm{A}$ informação também muda de posição na pós-modernidade, assumindo um papel estratégico e firmando-se como uma questão política, de modo a interferir de forma determinante nas relações de poder.

Kobashi e Tálamo (2003), trazendo a informação para o plano social, observam que, na sociedade contemporânea, a informação não se apresenta mais como uma questão puramente individual, ela passa a ser considerada um problema social.

No mundo pós-moderno, tanto a informação como o conhecimento passam pelo estabelecimento de valor. Da informação pública à informação científica, percebe-se que a sociedade tende a tratá-las como produto, gerando novas formas de concorrência. E mais: a ausência de políticas públicas de informação colabora para agravar esse problema, fazendo com que a informação fique nas mãos apenas daqueles que têm poder de compra. Com a tecnologia a seu favor, nota-se uma crescente ampliação e diversificação na produção da informação, nas possibilidades de suporte e nas demandas informacionais desses indivíduos e dos grupos que representam. Mark Pôster (apud BAUMAN, 1998, p. 201), ao apresentar as conseqüências culturais da era que teve início com o surgimento da Internet e da realidade virtual, salienta que

as palavras e imagens procriam com indecente rapidez, não arboreamente, [...] como numa fábrica centralizada, mas rizomicamente, em qualquer localização descentrada. A mudança para uma rede de comunicações descentralizada transforma os transmissores em receptores, os produtores em consumidores, os 
governantes em governados [...] perturbando a lógica de entendimento da primeira era dos meios de comunicação.

Todavia, essa mudança de estado do moderno para o pós-moderno não é uma mudança linear, ou seja, os espaços sociais não são homogêneos e, portanto, as pessoas acabam aprendendo a conviver com diferentes estados culturais.

No Brasil, assim como em outros países em situação econômica e social semelhante, caracterizados hierarquicamente como países de Terceiro Mundo ou em desenvolvimento, as desigualdades econômicas e sociais fazem com que esses estados de cultura se sobreponham com maior intensidade, gerando campos de tensão mais evidentes do que em países considerados de Primeiro Mundo ou desenvolvidos.

Nesse sentido, Santos (2005, p. 19), em seus estudos sobre a emancipação social, apresenta suas convicções sobre as influências das novas interdependências criadas pelo capital informacional e comunicacional. Para o autor, esses fatores aprofundaram as hierarquias do mundo. E mais: hoje estas hierarquias não são identificadas apenas entre países, mas também entre setores econômicos, grupos sociais, regiões, saberes, cultura e identidades.

É nesses países em desenvolvimento, e principalmente em regiões periféricas, - onde as populações têm maior dificuldade de acesso à informação, cultura, educação de qualidade e serviços públicos em geral, - que percebemos o surgimento de novos espaços de leitura, comumente denominados de "biblioteca comunitária". São espaços que se formam a partir de ações locais coletivas, baseadas em atitudes criativas e solidárias e lideradas por grupos que tomam para si o desafio de solucionar a carência da leitura e do acesso à informação, numa luta contra a crescente exclusão social.

Mas como surgem esses espaços? Quem são os atores que atuam nesses projetos? Como se estabelecem e se articulam na sociedade? Quais os impactos que geram na coletividade? Qual o papel da Biblioteconomia e da Ciência da Informação nesses processos? E mais, quais políticas públicas estão sendo implementadas para apoiá-las?

$\mathrm{Na}$ Biblioteconomia, o seu caráter ainda fortemente tecnicista colabora para o distanciamento entre a teoria e a prática, fazendo com que os profissionais da área conservem-se amarrados aos seus procedimentos padronizados, gerando um distanciamento da realidade e do que podemos chamar de conhecimento coletivo. 
Essa realidade vem sendo denunciada por inúmeros autores da área (ALMEIDA JUNIOR, 1995; FLUSSER,1980; MARTELETO; RIBEIRO, 2001) e pôde ser confirmada pelo diagnóstico situacional realizado no Departamento de Bibliotecas Públicas da Secretaria Municipal de Cultura (SMC) da Prefeitura do Município de São Paulo (PMSP), no ano de 2001 por Marina Cunali e Cecília Branco, órgão que naquele momento estava sob nossa direção (CUNALI; BRANCO, 2002).

Não podemos deixar de lembrar que foi na modernidade que as teorias e técnicas da Biblioteconomia se estabeleceram, pautada pelo pensamento funcional da época, de ordenar os livros, ordenar a informação para ordenar o conhecimento.

É a partir desse fenômeno que queremos refletir sobre o conceito e as características desses espaços. Se a academia já produziu muitos estudos sobre as bibliotecas universitárias, públicas, escolares e especializadas, pouco se sabe sobre as bibliotecas comunitárias. Seria esse um novo tipo de biblioteca?

\subsection{JUSTIFICATIVA}

A proposta desta pesquisa é fruto de nossa experiência, nos últimos dez anos, em trabalhos e projetos junto às bibliotecas públicas, bibliotecas comunitárias e projetos sociais ligados à informação, educação e cultura. A seguir destacamos alguns desses projetos:

$\checkmark$ "Identidade Cultural de Heliópolis", idealizado pelo arquiteto Ruy Ohtake, que teve como um dos subprojetos a criação da Biblioteca Comunitária de Heliópolis;

$\checkmark$ "Projeto Cidade Cidadã", um diagnóstico social local da cidade de São Caetano do Sul (SP);

$\checkmark$ "Consulado da Mulher", centros de informação para a mulher, criado no entorno das fábricas da Multibrás S/A;

$\checkmark$ "A comunidade se comunica através da escola", projeto de criação de jornal comunitário em escolas públicas do Estado de São Paulo;

$\checkmark$ "Enlaces Mundiais", projeto de formação de professores e alunos no uso pedagógico da internet; 
$\checkmark$ "Estadão na Escola", projeto de incentivo à leitura crítica do jornal, que teve como base uma hemeroteca eletrônica de artigos de jornais.

Durante esse período, final da década de 1990 e início do novo século, percebemos o aumento progressivo de projetos de desenvolvimento social no país nas mais diversas áreas e a conseqüente preocupação e conscientização da sociedade com relação ao acesso à informação como forma de transformação social.

Ao longo do tempo, as práticas e metodologias participativas foram se mostrando eficazes e sua aplicação se ampliando, num processo contínuo de mudança de mentalidade e de atitude, refletindo uma maior conscientização por parte dos grupos envolvidos; por conseguinte, ocorreu um maior engajamento em torno de questões coletivas.

Um fato sempre esteve presente nos projetos de que participamos: a baixa incidência de envolvimento de bibliotecários. É nesse sentido que surgiu a idéia de eleger a biblioteca comunitária como objeto de pesquisa.

Refletir sobre a biblioteca comunitária vai nos auxiliar, por um lado, a entender os fenômenos sociais que surgem de ações coletivas, como resposta a problemas e demandas coletivas informacionais. E, por outro lado, vai contribuir para a identificação de demandas reais desses espaços, de modo a se constituir como subsídio para a construção de políticas públicas efetivas para o fortalecimento desses espaços. Além disso, o direito à informação, garantido pela Constituição de 1988 no Brasil, nos aponta a necessidade de um olhar mais atento às questões sociológicas e antropológicas presentes nas praticas informacionais locais e do cotidiano.

Acreditamos que, para atuar em bibliotecas públicas, populares e comunitárias, exige-se do profissional, além do conhecimento técnico, sensibilidade, atitude pró-ativa, respeito às diferenças, estímulo e valorização ao protagonismo, cooperação, solidariedade e, acima de tudo, consciência do seu papel na sociedade, ou seja, responsabilidade social. Nesse sentido, é importante esclarecer que a nossa experiência na gestão do Departamento de Bibliotecas Públicas foi um fator que contribuiu de forma determinante para a escolha do tema bibliotecas comunitárias e práticas sociais. Durante o período em que estivemos na direção desse órgão, foi realizado um diagnóstico situacional das bibliotecas, com o objetivo 
de obter subsídios para iniciar um processo de elaboração de planejamento participativo, envolvendo o corpo técnico de funcionários vinculados ao Departamento e suas respectivas comunidades. Os resultados desse diagnóstico evidenciaram a falta de prática em ações participativas, a pouca compreensão das equipes das bibliotecas em relação ao seu papel social, cultural e político na sociedade e a falta de sensibilidade para relacionar-se com as comunidades.

A cultura dos espaços públicos e especialmente das bibliotecas, naquele momento, era totalmente impregnada de práticas e valores que não se adequavam às necessidades que a sociedade contemporânea exige. A idéia fixa dos bibliotecários - de segurança, perfeição e ordem - dificultavam a aproximação e o estabelecimento de relações com as suas comunidades, transformando esses espaços em ambientes vazios e sem vida e gerando mais conflitos com a comunidade do que ações que resultassem em respostas às demandas informacionais daqueles grupos.

Nesse contexto, para entender melhor essa problemática, acreditávamos ter dois caminhos a seguir: um seria aprofundar os estudos sobre bibliotecas públicas e, o outro, pesquisar ações espontâneas de criação de bibliotecas comunitárias que vêm surgindo pelo país, que pudessem ser referencial para ampliar as relações com a comunidade. Tendo em vista a quase inexistência de estudos sobre esses novos espaços e ações, decidimos pelo segundo caminho.

\subsection{OBJETIVOS}

A seguir, apresentamos o objetivo geral e os objetivos específicos da pesquisa em questão. 


\subsubsection{Objetivo geral}

Analisar a biblioteca comunitária como espaço de articulação local, seus atores, sua organização e o uso da informação nesse contexto e apontar políticas públicas para o fortalecimento e ampliação dessas iniciativas.

\subsubsection{Objetivos Específicos}

$\checkmark$ Gerar informações que ajudem a dimensionar e compreender a constituição de bibliotecas comunitárias no Brasil, suas características, semelhanças e diferenças em relação à biblioteca pública e popular;

$\checkmark$ Verificar como esse tipo de iniciativa organiza e disponibiliza a informação para a comunidade, seus recursos e potencialidades;

$\checkmark$ Identificar como essas bibliotecas se articulam com a comunidade local;

$\checkmark$ Identificar e examinar as políticas públicas criadas e que estão sendo implementada para esse segmento;

$\checkmark$ Fornecer subsídios para a administração pública fortalecer as políticas públicas, investindo na criação e ampliação de bibliotecas comunitárias.

\subsection{HIPÓTESE}

As bibliotecas que surgem nas comunidades locais, de maneira espontânea ou a partir de um projeto social, individual ou coletivo, são pólos irradiadores de cultura e saber local que, apoiadas pelo poder público, podem se transformar em espaços estratégicos para a implantação de políticas públicas de integração social e cultural. 


\subsection{REFERENCIAL TEÓRICO}

O referencial teórico sobre o tema "bibliotecas comunitárias" tem se apresentado muito escasso na literatura. São poucos autores que dedicam estudos sobre o assunto no Brasil: Todêska Badke (1984), Oswaldo Francisco Almeida Junior (1997), Geraldo Prado (2004), Maria Christina B. Almeida e Elisa Machado (2006), Waldomiro Vergueiro, Elisa Machado e Arturo Martin Vega (2007) e Marisa de Jesus (2007). Por esse motivo tomamos como base autores que vêm construindo um pensamento sobre a prática biblioteconômica e os serviços voltados para as questões da informação pública e da informação como instrumento de formação do cidadão no campo da Biblioteconomia e da Ciência da Informação. As reflexões sob o ponto de vista sociológico no campo da Ciência da Informação também nos ajudaram substancialmente na construção do referencial teórico desta pesquisa.

Dentro dessa perspectiva, apresentamos alguns pesquisadores brasileiros que, por meio de sua produção científica, colaboraram para a construção do referencial teórico desta pesquisa. São eles: Victor Flusser (1980, 1982, 1983), Luiz Milanesi (1985, 2002), Neusa Dias de Macedo e Laila Gebara Spinelli (1987), Waldomiro Vergueiro (1990, 2001), Lídia Freitas (1995), Emir Suaiden (1995), Gilda Verri (1996), Maria Nélida Gonzalez de Gomes (1999; 2000), Jose Teixeira Coelho Neto (2001), Regina Marteleto (2001), Nair Kobashi e Maria de Fátima Tálamo (2003) e Justino Lima (2006). No âmbito internacional citamos: Kevin McGarry (1999), Armand Mattelart (2002), Matthew Battles (2003), Peter Burke (2003), YvesFrançois Le Coadic (2004), Marc Baratin e Christian Jacob (2006), Jack Maness (2007), entre outros.

Considerando o baixo índice de relatos de experiências sobre o tema encontrado na literatura nacional, foi necessário um olhar sobre experiências semelhantes documentadas, em outros países. Desta forma, lançamos mão dos seguintes autores: Gerry Finnegan (1975), John Colson (1975), S. K. Croker (1975), T. Thomas (1975), William Martin (1975), John Crawford (2002) e Antonio Gorosito López (2003).

Comunidades e participação são temas que, para nós, estão estritamente relacionados e que estabeleceram o contexto para refletirmos sobre o nosso objeto de estudo. Portanto, partimos dos estudos teóricos sobre as comunidades e os 
processos de participação na sociedade contemporânea. Nesse sentido, Eric Hobsbawm fez a seguinte observação sobre o uso da palavra comunidade na sociedade contemporânea: "Jamais a palavra comunidade foi usada mais indiscriminadamente e vaziamente do que nas décadas em que as comunidades no sentido sociológico passaram a ser difíceis de encontrar na vida real”. (HOBSBAWM, 1996, p.416) Será que poderíamos dizer que o termo "biblioteca comunitária" também está seguindo o mesmo caminho?

O estudo sobre comunidades foi feito com base nas reflexões que são apresentadas por sociólogos, filósofos e pensadores do século XX e XXI, brasileiros e estrangeiros, tais como: Jürguen Habermas (1980), Marilena Chaui (1990; 1999), Anthony Giddens (1991), Eric Hobsbawm (1996), Pierre Levy (1998), Zygmunt Bauman (1998; 2003), Emir Sader (2000), Franco Berardi (2003), Mark Pôster (2003), Edgar Morin (2002; 2004), Beatriz Sarlo (2004), Hanna Arendt (2004), Stuart Hall (2005), entre outros.

Se no Brasil pouco se fala e escreve sobre bibliotecas comunitárias, menos ainda sobre a ação e gestão participativa na área da Biblioteconomia; por isso, foi necessário partir do referencial teórico das Ciências Sociais aplicadas à Educação Popular, Educação Ambiental, Administração, Economia e Política e da abordagem feita pelos seguintes autores: Outhwaite e Bottomore (1996), Boaventura de Souza Santos ( 2005), Marcos Kisil (2000), Danilo Gandin (2001), Carlos Passos (2003), Leonardo Boff (2003), Oakey e Clayton (2003), Paulo Freire (2003, 2006), Fábio Reis (2004), Archon Fung (2004), Denilson Werle (2004), José Bernardo Toro (2005), Maria da Glória Gohn (2005), Silvio Caccia Bava (2005) e Pierre Bourdieu (2005). Nesse sentido, concordamos com Nascimento e Marteleto (2004), quando insistem na necessidade da Ciência da Informação ampliar seus estudos a partir de uma base conceitual interdisciplinar construída com as Ciências Sociais.

Já a abordagem sobre as políticas públicas foi pautada no pensamento e nos estudos dos seguintes autores: Ladislau Dowbor (1994, 1995, 2006), Milton Santos (2000), Nicolau Sevcenco (2001), Marcos Pochmann (2003), Adauto Novaes (2007), Francis Wolf (2007), Franklin Leopoldo e Silva (2007), Lia Calabre (2007), Marilena Chaui (2007) e, por fim, Greiner Costa e Renato Dagnino (2008).

Não podemos deixar de citar, também, a literatura a cerca das condições e das relações estabelecidas pelos jovens na sociedade atual, que muito contribuiu para a compreensão do contexto em que se encontram as experiências pesquisadas 
nas zonas urbanas. Nesse âmbito, vale citar Márcia Wada (2004), Jailson de Souza e Silva e Jorge Luiz Barbosa (2005), Luiz Eduardo Soares, MV Bill e Celso Athayde (2005) e Michèle Petit (2008).

A partir desse referencial teórico, juntamente com a pesquisa de campo, partimos para uma reflexão aprofundada do nosso objeto de estudo, com o objetivo de criar condições para indicar quais as premissas que regem as ações das bibliotecas comunitárias e quais os desafios que estas organizações enfrentam.

\subsection{PROCEDIMENTOS METODOLÓGICOS}

A pesquisa e a reflexão sobre o processo de participação na formação de biblioteca comunitária estão intimamente relacionadas com a necessidade de comprovar as funções sociais da informação, relacionando-as ao comportamento da sociedade nos seus diversos contextos. É por esse motivo que a proposta em questão é apresentada dentro da linha de pesquisa Acesso à Informação.

Entendemos que:

O conhecimento científico é sempre uma busca de articulação entre uma teoria e a realidade empírica; o método é o fio condutor para se formular esta articulação. O método tem, pois, uma função fundamental: além do seu papel instrumental, é a "própria alma do conteúdo", como dizia Lênin (1965), e significa o próprio "caminho do pensamento", conforme a expressão de Habermas (1987) (MINAYO, 1993, p. 230).

Após a escolha do tema, partimos para a identificação das fontes primárias e secundárias, em busca de um referencial teórico e do estabelecimento do sistema conceitual referente ao objeto e contexto. A identificação das fontes de informação e a seleção dos textos e autores foram realizadas a partir das sugestões do orientador, das bibliografias estudadas nas disciplinas cursadas, das indicações fornecidas por colegas especialistas na área e, principalmente, do levantamento bibliográfico realizado a partir de fontes especializadas na área de Biblioteconomia e Ciência da Informação, assim como da mídia em geral, aqui considerada como fonte geral de informação. 
Esclarecemos que a pesquisa caminhou no sentido de descobrir as causas que levam ao surgimento das bibliotecas comunitárias, ou seja, um estudo da configuração desse fenômeno; portanto, teve como foco os sujeitos desse processo relacionados ao objeto da pesquisa e ao seu contexto. $\mathrm{E}$, por isso, a abordagem metodológica é considerada qualitativa e os resultados descritivos e analíticos.

Ressaltamos, no entanto, que ao apresentar os resultados como descritivos, isso não significa que a pesquisa teve caráter reducionista; afinal, o objetivo de uma pesquisa não é somente ver, mas, também, compreender, apresentar resultados de análise. Para tanto, esta pesquisa não levou em consideração somente o exterior aos sujeitos; pelo contrário. Nesse sentido, segundo Minayo

uma análise qualitativa completa interpreta o conteúdo dos discursos ou a fala cotidiana dentro de um quadro de referência, onde a ação e a ação objetivada nas instituições permitem ultrapassar a mensagem manifesta e atingir os significados latentes (MINAYO,1993, p. 246).

A pesquisa de abordagem antropológica propõe-se a ser de natureza aplicada, qualitativa e com objetivos exploratórios. O grupo de bibliotecas selecionado para se constituir no universo da pesquisa é aqui considerado como uma amostra típica, pois a seleção dos casos foi feita com base em amostragem não-probabilística intencional.

Foram realizados estudos de campo e essa opção se deu por serem esses baseados, fundamentalmente, em dados fornecidos por pessoas e porque "procuram muito mais o aprofundamento das questões propostas do que a distribuição das características da população segundo determinadas variáveis." (GIL, 1999, p. 72).

Para a realização do estudo de campo utilizamos as seguintes técnicas e instrumentos: a observação e a entrevista (APÊNDICE A). Com relação à opção pela observação, esclarecemos ainda que esta se deu pelas características que Florestan Fernandes levanta sobre esse método; segundo esse autor (apud LOPES, 1994, p. 124), a observação possui três características:

1. Transcende a mera constatação dos dados de fato;

2. Envolve a complementação dos sentidos por meios técnicos; 
3. Constitui o processo através do qual as instâncias empíricas, relevantes para a descrição ou a interpretação dos fenômenos sociais, são obtidas, selecionadas e coligadas.

Optamos pela observação direta, não-estruturada e, por conseguinte, participante. A observação se deu em duas dimensões: concreta e simbólica. A dimensão concreta refere-se ao olhar sobre o espaço, os procedimentos e a estrutura; e a dimensão simbólica refere-se ao significado dos sujeitos. A etapa completou-se na identificação da relação entre os sujeitos, atores do processo, com o espaço e os procedimentos adotados na constituição do objeto da pesquisa - a biblioteca comunitária.

Com base nos resultados obtidos nos estudos do grupo de bibliotecas selecionado, realizamos a análise e interpretação dos dados. É uma etapa muito delicada, pois, conforme já foi assinalado no início desta seção, estávamos lidando com a interpretação de ações e dimensionando a subjetividade daqueles que participam das ações.

Acreditamos que a aproximação entre sujeito e objeto foi o que nos apresentou os motivos, as intenções e os projetos dos atores, a partir de suas ações, estruturas e relações. A pesquisa de campo, somada ao referencial teórico e conceitual, indicou quais as premissas que regem as ações das bibliotecas comunitárias e quais os desafios que estas organizações enfrentam hoje, possibilitando, assim, a compreensão e a explicação desse fenômeno.

Considerando esse trabalho uma contribuição para as áreas de Biblioteconomia e Ciência da Informação, pretendemos abranger de forma exaustiva os campos acima delineados, por meio da literatura especializada e de procedimentos metodológicos que atendam de forma satisfatória à pesquisa.

O universo da pesquisa foi definido a partir de um levantamento preliminar de experiências de bibliotecas denominadas comunitárias. Foi realizado por meio da consulta ao banco de projetos do Plano Nacional do Livro e da Leitura (PNLL) e da mídia impressa e digital. Passamos a seguir à busca e organização de endereços e contatos com pessoas envolvidas na implantação dessas bibliotecas e de pesquisadores envolvidos com o tema.

Tivemos acesso também aos resultados parciais da pesquisa em andamento "Bibliotecas comunitárias no semi-árido brasileiro", sob a responsabilidade do 
professor Geraldo Moreira Prado. Somaram-se também, os dados coletados nas pesquisas realizadas pelas alunas Ana Margareth do Nascimento Amorim, Fabiana Vilar e Terezinha Puppim, as quais desenvolveram Trabalhos de Conclusão de Curso na Escola de Biblioteconomia da UNIRIO sobre o tema, sendo que duas delas sob a orientação da autora. O projeto de pesquisa "Biblioteca como prática de responsabilidade social", também sob a coordenação da autora e vinculado à Universidade Federal do Estado do Rio de Janeiro (UNIRIO), foi outra fonte de informação considerada.

A partir do conjunto de dados levantados, iniciamos a consulta direta, via telefone e/ou e-mail, e ainda, quando possível, presencialmente, às pessoas envolvidas nos projetos identificados no levantamento preliminar. Nesse momento, procuramos identificar: como surgiu a proposta de criação da biblioteca; qual o motivo que levou à denominação de biblioteca comunitária; sua localização e as condições sociais, culturais e econômicas da comunidade a que atende; se possui vínculo com órgãos governamentais ou recebe algum tipo de apoio de instituições da sociedade civil; e, se haveria algum impedimento em ser objeto de uma pesquisa acadêmica.

Em junho de 2008, encerramos a etapa de coleta de dados com um total de 350 experiências cadastradas. Esclarecemos que a sistematização dos dados coletados foi realizada por meio da inserção dos mesmos numa planilha Excell, contendo os seguintes campos: nome da biblioteca; unidade da federação; município; bairro; complemento; entidade responsável; endereço completo; telefones; site; endereço eletrônico; responsável pela biblioteca; articulações locais; outros detalhamentos; fonte da informação coletada. Futuramente, pretendemos importar esses dados para um banco passível de ser disponibilizado na WEB. Acreditamos que esse possa ser um dos primeiros passos para fomentar uma rede de informação sobre bibliotecas comunitárias.

Das 350 experiências, 29 foram analisadas com base em visitas e/ou entrevistas, sendo que, nem todos os contatos foram feitos no espaço da biblioteca, tendo em vista as dificuldades de acesso a regiões mais afastadas. No entanto, nesses casos tivemos contato direto com integrantes desses projetos, os quais nos concederam entrevistas e apresentaram registros fotográficos e textuais que documentam as atividades da biblioteca. Esse grupo é considerado o nosso universo da pesquisa e é composto pelas seguintes experiências: 


\begin{tabular}{|c|c|c|c|c|}
\hline & BIBLIOTECA & UF & CIDADE & BAIRRO/REGIÃO \\
\hline 1 & BVL de Macapá & AP & Macapá & Corre Água do Piririm \\
\hline 2 & BC Maria das Neves Prado & $\mathrm{BA}$ & Nova Soure & São José do Paiaiá \\
\hline 3 & BC T Bone & DF & Brasília & Asa Norte \\
\hline 4 & BVL da Comunidade Santa Tereza & MA & Mirinzal & Quilombo Santa Tereza \\
\hline 5 & BC de Poços de Caldas & MG & $\begin{array}{l}\text { Poços de } \\
\text { Caldas }\end{array}$ & Zona rural \\
\hline 6 & BVL da Comunidade Bengui & PA & Belém & Benguí \\
\hline 7 & BC Ler é Preciso de Magé & RJ & Magé & Zona rural \\
\hline 8 & BC Ler é Preciso Diuner Mello & RJ & Paraty & Taquari, zona rural \\
\hline 9 & BC Emmanuel & RJ & Rio de Janeiro & Magalhães Bastos \\
\hline 10 & BC do Espaço Criança Esperança & RJ & Rio de Janeiro & $\begin{array}{l}\text { Ipanema (Morro do } \\
\text { Cantagalo) }\end{array}$ \\
\hline 11 & BC Ler é Preciso de Copacabana & RJ & Rio de Janeiro & Copacabana \\
\hline 12 & BC Paulo Coelho & RJ & Rio de Janeiro & $\begin{array}{l}\text { Copacabana (Morro do } \\
\text { Pavão e Pavãozinho) }\end{array}$ \\
\hline 13 & BC Paulo Freire & RJ & Rio de Janeiro & $\begin{array}{l}\text { Maré (Morro do } \\
\text { Timbaú) }\end{array}$ \\
\hline 14 & BC Tobias Barreto & RJ & Rio de Janeiro & Penha \\
\hline 15 & BVL da Comunidade de Caracaraí & RR & Caracaraí & Vista Alegre \\
\hline 16 & BVL da Comunidade Boca da Mata & RR & Pacaraima & Boca da Mata \\
\hline 17 & BVL da Comunidade Santa Rosa & $\mathrm{RR}$ & Pacaraima & Santa Rosa \\
\hline 18 & BC Zumaluma & SP & $\begin{array}{l}\text { Embu das } \\
\text { Artes }\end{array}$ & Favela do Inferninho \\
\hline 19 & $\begin{array}{l}\text { Biblioteca Confraria dos Parceiros } \\
\text { de Guararema }\end{array}$ & SP & Guararema & Zona rural \\
\hline 20 & BC Prof. Waldir de Souza Lima & SP & Itu & Centro \\
\hline 21 & Biblioteca Solidária & SP & $\begin{array}{l}\text { São José dos } \\
\text { Campos }\end{array}$ & $\begin{array}{l}\text { Distrito de São } \\
\text { Francisco Xavier }\end{array}$ \\
\hline 22 & BC Casulo & SP & São Paulo & Parque Real \\
\hline 23 & BC Cultura Jovem & SP & São Paulo & Jardim Ângela \\
\hline 24 & BC dos Garis & SP & São Paulo & Centro \\
\hline 25 & BC de Heliópolis & SP & São Paulo & Favela de Heliópolis \\
\hline 26 & BC Ler é Preciso da Coopamare & SP & São Paulo & Pinheiros \\
\hline 27 & BC Livro-Pra-Quê-Te-Quero & SP & São Paulo & $\begin{array}{c}\text { Parque Bristol/Vila } \\
\text { Livieiro }\end{array}$ \\
\hline 28 & BC Prestes Maia & SP & São Paulo & Centro \\
\hline 29 & BC Solano Trindade & SP & São Paulo & Cidade Tiradentes \\
\hline
\end{tabular}

Quadro 1 - Relação de experiências analisadas

Fonte: 0 autor (2008) 


\section{PRÁtICAS SOCIAIS E POLÍTICAS PÚBLICAS NA SOCIEDADE CONTEMPORÂNEA}

o que globaliza separa; é o local que permite a união Milton Santos

Retomando ao que foi escrito no início deste trabalho sobre as mudanças que a sociedade contemporânea está vivendo, esclarecemos que, para fazer referência aos tempos atuais, muitas vezes utilizaremos o termo "pós-modernidade", apesar de todas as controvérsias que ele carrega, justamente por acreditar que essa é uma característica interessante desses tempos, ou do estado da cultura em que estamos vivendo.

Pós-modernidade é considerado aquele momento em que os conceitos e princípios estabelecidos pela sociedade moderna estão sendo colocados em xeque. Para explicar o mundo moderno, Freud, no início do século passado, fez o seguinte comentário: "o homem civilizado trocou um quinhão das suas possibilidades de felicidade por um quinhão de segurança” (FREUD apud BAUMAN, 1998, p. 8). Bauman, nos dias atuais, ao fazer um paralelo entre o discurso de Freud sobre "O mal estar da cultura" e a sociedade contemporânea afirma que:

\footnotetext{
os mal-estares da modernidade provinham de uma espécie de segurança que tolerava uma liberdade pequena demais na busca da felicidade individual. Os mal-estares da pós-modernidade provêm de uma espécie de liberdade de procura do prazer que tolera uma segurança individual pequena demais (BAUMAN, 1998, p. 10).
}

Sobre esse estado de cultura e, por conseguinte, novas formas de comportamento do homem, surgem preocupações sobre vários aspectos das relações humanas. Habermas ataca a modernidade técnica e o uso maciço da razão instrumental-analítica, a serviço dos interesses do projeto de tecnociência e da dominação política sobre classes, nações e povos (HABERMAS apud BOFF, 2003, p. 45). Anthony Giddens (1991, p. 29) apresenta a preocupação com o que denomina de "desencaixe" do sistema social e com o fim das relações sociais nos contextos locais de interação. O autor considera "desencaixe [0] deslocamento das relações sociais de contextos locais de interação e sua reestruturação através de extensões indefinidas de tempo-espaço." 
Ao falar das tendências pós-modernas globais, Stuart Hall (2005, p. 76) ressalta a tensão entre o global e o local na transformação das identidades.

As identidades nacionais representam vínculos a lugares, eventos, símbolos, histórias particulares. Elas representam o que algumas vezes é chamado de uma forma particularista de vínculo ou pertencimento.

Nesse contexto, a preocupação com a experiência da comunidade é percebida e vem sendo discutida por muitos autores (ARENDT, 2004; BAUMAN, 2003; HOBSBAWM, 1996). A seguir discutiremos as diversas formas de entendimento do conceito de comunidade na sociedade contemporânea, passando pelas questões que envolvem as práticas sociais e os processos participativos, para, por fim, discutir a questão da mobilização cidadã e as políticas públicas.

\subsection{O CONCEITO DE COMUNIDADE}

O cuidado é o permanente companheiro do ser humano. Horário (65-8 a.C.)

Hillery (apud FUNDAÇÃO GETÚLIO VARGAS, 1986, p. 229) examinou noventa e quatro definições de comunidade e concluiu que não existe consenso entre os cientistas sociais quanto a sua natureza. O termo é normalmente empregado como sinônimo de sociedade, organização social ou sistema social, porém, os autores estudados por Hillery concordam que a comunidade tem um lócus territorial específico e limitado que a diferencia.

Apesar de sua importância na vida das pessoas, nas ciências sociais, como conceito analítico, comunidade tem pouco valor, pois "tornou-se uma palavra de ordem carregada de associações emotivas de inteireza, coesão, comunhão, interesse público e tudo de bom" (OUTHWAITE; BOTTOMORE, 1996, p. 116). Apesar disso,

no mínimo, comunidade geralmente indica um grupo de pessoas dentro de uma área geográfica limitada que interagem dentro de instituições comuns e que possuem um senso comum de interdependência e integração. Não obstante, conjuntos de indivíduos vivendo ou interagindo dentro de um mesmo território não constituem em si mesmo comunidades - particularmente se esses 
indivíduos não se consideram como tal. O que une uma comunidade não é a sua estrutura, mas um estado de espírito - um sentimento de comunidade. Essa divisão subjetiva torna comunidade algo problemático como instrumento de análise sociológica, pois os limites de qualquer grupo com auto-identificação, da perspectiva do que está dentro, são geralmente fluidos e intangíveis, em vez de fixos e finitos (OUTHWAITE; BOTTOMORE, 1996, p. 115).

Marilena Chaui, em sua obra "Convite à filosofia", apresenta o conceito de comunidade como "um grupo ou uma coletividade onde as pessoas se conhecem, tratam-se pelo primeiro nome, possuem contatos cotidianos, cara a cara, compartilham os mesmos sentimentos e idéias e possuem um destino comum" (CHAUI, 1999, p. 296).

A comunidade também é caracterizada por Gohn (2005, p. 53) como "um campo multifacetado, de uma esfera pública", onde uma diversidade de atores sociais, muitos deles ligados ao Terceiro Setor ${ }^{1}$ se articulam. A mesma autora vê a comunidade como uma "força local organizada".

Para entendermos a afirmação acima, consideramos importante recorrer à noção de "campo" apresentada por Pierre Bourdieu (2005). Para o autor, todas as sociedades se apresentam como espaços sociais, constituídos com base no princípio da estrutura da distribuição das formas de poder ou dos tipos de capital, que variam de acordo com os lugares e os momentos. Pierre Bourdieu descreve os espaços sociais globais como um campo de forças e de lutas e esclarece:

como um campo de forças, cuja necessidade se impõe aos agentes que nele se encontram envolvidos, e como um campo de lutas, no interior do qual os agentes se enfrentam, com meios e fins diferenciados conforme sua posição na estrutura do campo de forças, contribuindo assim para a conservação ou a transformação de sua estrutura (BOURDIEU, 2005, p. 50).

Hannah Arendt (2004) traz para o contexto da comunidade a questão da responsabilidade individual e coletiva e, por conseguinte, a questão da participação e da não-participação. Segundo a autora, só podemos escapar da responsabilidade política e estritamente coletiva abandonando a comunidade; porém, segundo ela, nenhum homem pode viver sem pertencer a uma comunidade, o máximo que ele

\footnotetext{
${ }^{1}$ Organizações Não Governamentais (ONGs), Organizações de Assistência Social, Fundações Sociais de empresas privadas, Universidades, Sindicatos, Movimentos Sociais entre outros.
} 
pode fazer é trocar uma comunidade por outra e, assim, um tipo de responsabilidade por outro.

Nos textos sobre responsabilidade, Arendt relaciona as atividades da vida, do espírito à ação e à responsabilidade pessoal, traçando um caminho entre a singularidade de cada indivíduo e a pluralidade do espaço público, alertando para a perceptível desvalorização da atividade de agir conjuntamente.

Ao analisar o pensamento de Arendt de "ser-do-mundo" em oposição ao "estar-no-mundo", Assy afirma que essa fenomenologia arendtiana

visa a uma nova simbologia cultural que leva em conta também uma forma pública de vida. De modo que, ao final, uma parcela considerável da nossa satisfação seria fruto do compromisso com a comunidade na qual vivemos, por meio do reconhecimento da superioridade do cuidado com o mundo e com o bem-estar coletivo sob os caprichos e interesses individuais (ASSY, 2004, p. 45).

Zygmunt Bauman (2003, p. 8) abre seu livro sobre o tema apresentando o termo comunidade como uma dessas palavras que, além de significado, guardam sensações, "sugere uma coisa boa: o que quer que comunidade signifique, é bom ter uma comunidade, estar numa comunidade. O que a palavra evoca é tudo aquilo de que sentimos falta e de que precisamos para viver seguros e confiantes."

Porém, ao longo de seu texto o autor vai questionando e desmistificando essa atração pela comunidade dos sonhos apregoada pelo pensamento único da sociedade de mercado, e apresenta, por meio de uma análise rica e contundente, 0 que acredita serem os valores da comunidade original: "a igualdade de recursos necessários para transformar o destino dos indivíduos de jure em indivíduos de facto, e um seguro coletivo contra incapacidades e infortúnios individuais." (BAUMAN, 2003, p. 133, grifo do autor).

Em tempos de pós-modernidade, deparamo-nos com uma nova forma de convergência social: as chamadas comunidades virtuais, organizadas em espaços invisíveis, que não são mais caracterizados como territórios geográficos, dentro de uma cultura de rede.

A sociedade em geral utiliza o termo comunidade virtual para se referir ao conjunto de pessoas que participam de atividades em espaços virtuais criados na Internet, tais como Orkut e Second Life.

Pierre Levy trata do assunto apresentando três tipos ideais de grupos: 
As famílias, os clãs e as tribos são grupos orgânicos. Os Estados, as instituições, as Igrejas, as grandes empresas, assim como as 'massas' revolucionárias são grupos organizados, molares, que passam por uma transcendência ou exterioridade para se constituir e se manter. Enfim, os grupos auto-organizados, ou grupos moleculares, realizam o ideal da democracia direta nas enormes comunidades em situação de mutação e desterritorialização (LEVY, 1998 , p. 55, grifo do autor).

Ainda segundo o mesmo autor, "o ciberespaço permite conceber formas de organização econômica e social centradas na inteligência coletiva e na valorização do humano em sua variedade [...]" (LEVY, 1998, p. 54, grifo do autor). Para Levy, a inteligência coletiva "é uma inteligência distribuída por toda parte, incessantemente valorizada, coordenada em tempo real, que resulta em uma mobilização efetiva das competências." (1998, p. 28)

Ao se referir à rede Internet, Franco Berardi (2003, p. 290) esclarece que esta "é um modelo de concatenação dos segmentos produtivos e lingüísticos. Trata-se de um paradigma que se embrenha profunda e irreversivelmente nos circuitos de trocas da esfera da informática produtiva."

É verdade que o discurso da atualidade enfatiza o coletivo, o trabalho em grupo, a cooperação, a colaboração e o compartilhamento de conhecimento, porém, em oposição ao otimista Pierre Levy, Berardi (2003) ressalta que, apesar de já termos infra-estrutura para potencializar essas práticas, os estudos vêm demonstrando que a sociedade caminha no sentido do isolamento $\mathrm{e} d a$ individualização se contrapondo às construções coletivas tão idealizadas. Mark Pôster (2003) ressalta, por sua vez, que a Internet contém potencialmente essas novas práticas, porém o processo de concretizar esse potencial é um processo político.

Com base no exposto acima, podemos inferir que uma comunidade é basicamente formada por um número pequeno de indivíduos, os quais estão situados num local comum, onde se percebem vinculados por suas histórias passadas, por suas expectativas futuras e por seus conhecimentos compartilhados. Entendemos, também, que em uma comunidade os seus membros são pessoas livres, porém engajadas, ou melhor, comprometidas com um objetivo comum, e que têm responsabilidades sobre suas decisões. Estão participando de ações na esfera pública, cultivando a sociabilidade e praticando o exercício constante da negociação. As relações e os laços humanos e sociais são determinantes, ou seja, é importante 
pertencer a uma família, a uma vizinhança ou a uma instituição, seja ela a escola, a igreja, a empresa ou qualquer outra instituição.

Esses grupos podem ser comunidades moradoras de um mesmo local, uma vila, um bairro, uma favela. Estudantes, funcionários e professores de uma determinada instituição que se conhecem, convivem, trocam dia-a-dia informação construindo histórias comuns e criando novos caminhos. Grupos de pessoas que se unem por afinidade e por objetivos comuns e elegem um espaço comum para se encontrar, seja real ou virtual.

\subsection{PRÁTICAS SOCIAIS E PROCESSOS PARTICIPATIVOS}

As questões que envolvem a prática e o homem como agente da ação datam da antiguidade e Marilena Chaui faz uma bela explanação desses pensamentos no seu livro "Introdução a história da filosofia". Chaui (2002) esclarece que é Aristóteles quem apresenta a práxis como uma das finalidades da ação e, a partir da natureza das coisas investigadas, diferencia e classifica as ciências em três grupos: as teóricas que incluem a física, a matemática e a filosofia; as práticas, com a ética e a política; e, por fim, as produtivas, onde se enquadram a agricultura, a metalurgia, a tecelagem, a marcenaria, a engenharia entre outras.

As ciências práticas se referem à práxis como algo propriamente humano. Uma ciência não contemplativa, onde a ação não é necessária e sim possível e não é universal e sim particular. Para Aristóteles a práxis:

é aquilo que pode acontecer ou deixar de acontecer, uma possibilidade que depende da vontade racional do agente. Particular, porque acontece de uma maneira determinada, pois uma ação ou um acontecimento dependem das características pessoais do agente, das circunstâncias em que ele age e da finalidade da ação no momento em que foi realizada (CHAUI, 2002, p. 349).

Naquele momento o pensador estava preocupado em conhecer, por meio das ciências práticas, as causas e os princípios das ações humanas em relação a sua finalidade, que para ele era objetivamente alcançar o Bem. Para Aristóteles, "o Bem é a medida da independência e da auto-suficiência de alguém." (CHAUI, 2002, p. 349). 
Saltando da Antiguidade para os dias de hoje, encontramos Edgar Morin (2002) discutindo a noção de ecologia da ação, que leva em consideração a complexidade, ou seja, a ação envolvendo mais do que escolha e decisão, envolvendo também o risco e a incerteza. Para o autor,

tão logo um indivíduo empreende uma ação, qualquer que seja, esta começa a escapar de suas intenções. Esta ação entra num universo de interações e é finalmente o meio ambiente que se apossa dela, em sentido que pode contrariar a intenção inicial (MORIN, 2002, p. 86).

Pierre Bourdieu, por sua vez, ao discutir a "prática", apresenta-nos a filosofia da ação, a qual é baseada nos fundamentos do habitus, do campo e do capital, tendo como ponto central a relação entre as estruturas objetivas e as estruturas incorporadas. Para o autor as estruturas objetivas referem-se aos campos sociais e as estruturas incorporadas são definidas pelo habitus e esses, por sua vez, "são os princípios geradores de práticas distintas e distintivas." (BOURDIEU, 2005, p. 22).

Estas práticas se apresentam num espaço social, o qual é constituído por uma estrutura de diferentes tipos de capital - capital econômico, social, cultural, escolar ou político. E, nesse sentido, afirma que

Se o mundo social, com suas divisões é algo que os agentes sociais têm a fazer, a construir, individual e sobretudo coletivamente, na cooperação e no conflito, resta que essas construções não se dão no vazio social [...] a posição ocupada no espaço social, isto é, na estrutura de distribuição de diferentes tipos de capital, que também são armas, comanda as representações desse espaço e as tomadas de posição nas lutas para conservá-lo ou transformá-lo (BOURDIEU, 2005, p. 27).

De acordo com a filosofia da ação, podemos inferir que a sociedade cria mecanismos que asseguram a reprodução do espaço social como ele é e dificulta a implementação de ações transformadoras.

O processo comunicativo é apontado por Jürguen Habermas (FREITAG; ROUANET, 1980) como um desses mecanismos, visto que, para o autor, todas as sociedades que se constituíram ao longo da história, caracterizam-se pela deformação sistemática do processo de comunicação, ou seja, a problematização discursiva é negada, obstruindo assim a comunicação.

Já o sociólogo português Boaventura de Souza Santos acredita que é possível inverter esse processo e apresenta em seu livro "Democratizar a 
democracia: os caminhos da democracia participativa" algumas experiências de práticas transformadoras. Para o autor, apesar da globalização neoliberal ter um peso muito grande sobre a sociedade e ser hegemônica, em reação a ela, está surgindo uma outra globalização, a globalização alternativa,

constituída pelas redes e alianças transfronteiriças entre movimentos para lutar contra a exclusão social, a precarização do trabalho, o declínio das políticas públicas, a destruição do meio ambiente e a biodiversidade, o desemprego, as violações dos direitos humanos, as pandemias, os ódios interétnicos produzidos direta ou indiretamente pela globalização neoliberal (SANTOS, 2005, p. 13).

Paulo Freire, por meio da educação, prova que é possível inverter a ordem e implantar ações transformadoras. Para isso, desenvolve suas teorias pedagógicas, baseando-se no principio de que a educação é uma prática de liberdade e que aprender a ler e escrever só tem valor à medida que desenvolve capacidades nas pessoas de participar de maneira ativa na sociedade. É nesse contexto que afirma que a "práxis é a reflexão e a ação dos homens sobre o mundo para transformá-lo." (FREIRE, 2003, p. 38). Para o autor é a reflexão que conduz à prática, e estas se dão simultaneamente, do contrário a ação não passa de mero ativismo, porém, ressalta também a importância entre o equilíbrio nesse processo, ou seja, nem só reflexão, nem só ação.

As teorias de Paulo Freire nos dão uma chave para enfrentar os obstáculos apontados na teoria da competência comunicativa desenvolvida por Habermas. Alguns autores (REIS, 2004; FUNG, 2004; WERLE, 2004) apresentam a teoria da ação comunicativa de Habermas como um forte componente para o processo participativo, visto que essa teoria defende a participação de todos os interessados nos contextos discursivos, sem obstrução da problematização discursiva. A ação comunicativa "remete de antemão a possibilidade de que os participantes da interação distingam com mais ou menos clareza a influência de uns sobre os outros e o entendimento de uns com os outros." (HABERMAS, 1988, p. 108, tradução nossa).

Cabe esclarecer que quando Habermas apresenta os princípios do agir comunicativo ele está se referindo à interação social e à compreensão mútua e consensual entre os indivíduos dentro de uma situação lingüística ideal. Para Habermas (apud FREITAG; ROUANET, 1980, p. 18), a situação lingüística ideal é 
aquela na qual "a comunicação não é perturbada nem por efeitos externos contingentes, nem por coações resultantes da própria estrutura da comunicação. A situação lingüística ideal exclui deformações sistemáticas da comunicação."

Paulo Freire (2003) estabelece também uma relação entre a prática e a participação ao defender a ação conjunta, na qual a transformação da realidade só será possível se estiverem envolvidos não apenas um, mas vários atores dialogando de maneira solidária - são os indivíduos como sujeitos do processo. Esses princípios permeiam as teorias da ação cultural dialógica, que só é possível ser gerada a partir de um pensamento crítico.

A importância da participação como princípio é consenso, porém o processo de participação e os métodos utilizados são apresentados sob diversos pontos de vista. Freire levanta a questão da manipulação e defende que o antídoto para ela é a organização criticamente consciente. Para o autor, a manipulação está na teoria da ação antidialógica, a qual "tem que anestesiar as massas populares para que não pensem." (FREIRE, 2003, p. 146).

Outro educador que discute de maneira contundente a questão da manipulação nos processos participativos é Danilo Gandin. O autor, ao apresentar o planejamento participativo na educação, alerta para três desastres graves em relação ao conceito de participação:

a manipulação das pessoas pelas 'autoridades', através de um simulacro de participação; a utilização de metodologias inadequadas, com o conseqüente desgaste da idéia; a falta de compreensão abrangente da idéia de participação (GANDIN, 2001, p. 88).

Estas particularidades são evidenciadas também por Marcos Kisil (2000), ao categorizar as formas de participação: a participação como um meio e a participação como um fim. Para melhor esclarecer a diferença entre as categorias, o autor toma como base três interpretações do termo "participação", que transcrevemos a seguir:

Participação significa [...] no seu sentido mais amplo, sensibilizar as pessoas e assim aumentar a receptividade e habilidade delas com relação aos programas de desenvolvimento, assim como encorajar as iniciativas locais (LELE, apud KISIL, 2000, p. 149).

Nesse caso, segundo Kisil, a participação é um meio de se atingir um objetivo, um modo de usar a comunidade a favor de um projeto. Aqui, os resultados 
são mais importantes que o processo. É um modo de ver a participação como uma técnica gerencial, pautada no cooptação de pessoas ou comunidades. Para nós, esta forma de participação, facilmente, poderá se transformar em manipulação.

As duas outras definições, apresentadas pelo mesmo autor, referem-se a interpretações diferentes, que vêem a participação como um fim.

Com referência a [...] participação, ela inclui o envolvimento das pessoas no processo de tomada de decisão, na implementação de programas [...], na repartição dos benefícios dos programas desenvolvidos e seu envolvimento nos esforços para avaliar tais programas (LISK apud KISIL, 2000, p. 149).

Participação envolve [...] esforços organizados para aumentar o controle sobre os recursos e instituições reguladoras em situações sociais dos grupos ou movimentos excluídos daquele controle (PEARSE, apud KISIL, 2000, p. 149)

Nesses casos, segundo Kisil (2000, p. 149), "a ênfase é colocada na participação como processo no qual a confiança e a solidariedade entre as pessoas são estabelecidas". Deixa de ser uma técnica de gestão e passa a ser um meio de formação de pessoas.

Entendemos que nesta segunda forma de participação, que valoriza o processo e permite ao indivíduo participar da tomada de decisão, está intrínseco o diálogo e a negociação, ou seja, segue a linha da teoria da ação cultural dialógica formulada por Paulo Freire. A partir dessa idéia de participação como processo de formação, acreditamos que, partindo de um saber muitas vezes prático, os protagonistas de processos participativos colaboram para a emancipação social.

Por outro lado, um dos grandes argumentos contrários a práticas participativas refere-se à condição dos grupos para agir como membros participantes de um projeto. Esse tipo de argumento segue a mesma linha de pensamento daqueles que questionam a democracia. Nesse sentido, Amartya Sem (apud SOUZA, 2005, p. 41) afirma que "a questão não é a de saber se um dado país está preparado para a democracia, mas, antes, de partir da idéia de que qualquer país se prepara através da democracia". Fazendo um paralelo, podemos dizer que, em relação à implantação de processos participativos em projetos, a questão não é saber se um determinado grupo ou comunidade está preparado para a pratica participativa, mas, sim, partir da idéia de que qualquer grupo ou comunidade se prepara por meio da participação. 
Segundo Marilena Chaui (2006, p. 140),

a democracia exige a ampliação da representação pela participação, - que leva ao surgimento de novas práticas que garantam a participação como ato político efetivo [...] em outras palavras, só há democracia com a ampliação contínua da cidadania.

Essa referência é feita pela autora para explicar a idéia de cidadania cultural que permeou a política cultural implementada por ela, durante sua gestão na Secretaria Municipal de Cultura da cidade de São Paulo, no período de 1988 a 1992. A autora define cidadania cultural como:

a idéia em que a cultura não se reduz ao supérfluo, ao entretenimento, aos padrões do mercado, à oficialidade doutrinária (que é ideologia), mas que se realiza como direito de todo cidadão [...] (CHAUI, 2006, p. 138).

Ainda segundo a autora, "no Brasil, conhecemos duas apropriações nãorevolucionárias da participação: a socialdemocrata e liberal, de um lado, e a da democracia-cristã, de outro." (CHAUI, 2006, p. 146). A socialdemocrata e liberal é vista como pressão sobre os órgãos públicos de poder e tornou-se para a classe dominante sinônimo de lobby e, para a classe trabalhadora, reivindicação ou demanda. A democracia-cristã refere-se à realização de uma ação com vistas a suprir uma carência, tal como o mutirão. Dessa forma, temos "duas apropriações do conceito de participação e da sua prática: ou fica reduzida a formas variadas de pressão ou se reduz ao trabalho popular coletivo e voluntário." (CHAUI, 2006, p. 146).

A complexidade da sociedade nos dias de hoje, cria também inúmeros obstáculos para a participação direta dos cidadãos na vida pública. Idealmente buscamos a combinação da participação representativa com a direta, porém, na realidade o que percebemos é que a participação representativa prevalece sobre a participação direta.

O Brasil tem se destacado como um país que vem, ao longo dos últimos anos, ampliando esses canais de participação. A Constituição de 1988 foi um dos grandes avanços nesse sentido, ela prevê a participação da comunidade na saúde, na assistência social, na educação, cultura, assim como nas questões relativas à criança e do adolescente. O problema é que esses canais, muitas vezes, são 
subutilizados pelo cidadão. Muitos são os motivos que levam a isso, da falta de informação ao descrédito no poder público.

$\mathrm{Na}$ esfera pública, existem vários canais de participação: conselhos, conferências, assembléias, audiências públicas, orçamentos participativos, mecanismos deliberativos das agências reguladoras. Em sua maioria, esses canais são destinados à participação representativa.

A forte atuação das organizações da sociedade civil durante o período de transição para o regime democrático foi um dos grandes motivos que colaboraram para o avanço do processo participativo e democrático no país. Essas instituições surgiram para lidar com questões voltadas à proteção ambiental, aos direitos humanos, e a demandas locais, como é o caso das inúmeras associações de moradores que proliferaram a partir do final dos anos 70. Essas organizações atuaram de forma pedagógica e instigaram, por meio de suas ações locais e mobilizações comunitárias, o desenvolvimento de novos valores democráticos na sociedade civil brasileira, ultrapassando assim o ideal democrático normativo que vê a participação relacionada unicamente com a possibilidade do cidadão exercer seu poder de voto.

A capacidade de ação e de participação de um cidadão é bem diferente da capacidade de ação de uma organização da sociedade civil, de uma empresa, ou do Estado. "Saber organizar-se e associar-se é a ciência-mestra de uma sociedade porque assim se produz auto-regulação e assegura-se a proteção aos direitos" (TORO, 2005, p. 22). Não obstante a existência dos espaços de participação, conforme já identificamos acima, o simples fato deles existirem não garante resultados.

Baseando-se no que os autores acima citados nos apontam sobre a questão da participação, fica evidente que estamos diante de uma ação que depende não só da vontade do homem como agente da ação, mas também de acesso à informação, da autonomia, do espaço e da posição desse agente nesse espaço social, da reflexão e, por conseguinte, de postura crítica, ou seja, existem condições para que o processo participativo se instale. Certamente não é qualquer ação que promove a participação ativa e crítica de um agente individual ou coletivo.

Além disso, não podemos nos esquecer de que os espaços participativos nos remetem à idéia do espaço de conflito, já que além dos campos de força e luta, e dos processos de comunicação inerentes aos espaços sociais, temos aqui também a 
prática da ação conjunta, que é decorrente de relações entre indivíduos que geram praticas sociais, as quais podem ser articuladas, desarticuladas e rearticuladas de diferentes maneiras e que, por conseguinte, tendem a gerar conflito. Para nós, esse conjunto de fatores é visto pela sociedade como forte inibidor dos processos participativos e é amplamente utilizado pela elite dominante para desarticular as práticas sociais participativas.

\subsection{SOCIEDADE CIVIL E POLÍTICAS PÚBLICAS}

O homem é um deus para o homem [...] com a ajuda mutua, podem conseguir muito mais facilmente aquilo de que têm necessidade e somente unindo suas forças podem evitar os perigos que os ameaçam de todos os lados.

Espinosa

Retomando ao nosso contexto, onde a pós-modernidade é caracterizada como a era da desregulamentação e a modernidade a era da segurança, é importante lembrar que foi na modernidade que se criou o "Estado de bem-estar social", em que os Estados Nacionais controlavam a economia e as corporações, porém, foi também na modernidade que o pensamento liberal começou a se estabelecer.

$\mathrm{Na}$ pós-modernidade, o contraste entre liberalismo e democracia, e o pensamento e os valores neoliberais, se sobrepõem. Cai por terra o princípio do "Estado de bem-estar social" e surgem impasses éticos provocados pela globalização dos mercados e da informação.

Nesse contexto, como ficam as ações individuais e as ações coletivas oriundas de organizações da sociedade civil, de movimentos e redes sociais, de empresas privadas ou do Estado? Podemos considerá-las ações políticas? Hanna Arendt (apud SILVA, 2007, p. 130) nos dá essa resposta a partir da seguinte afirmação: "política não é uma qualidade dos indivíduos, essencial ou acidental, mas algo que ocorre entre os indivíduos, no espaço comum da vida pública".

A noção que temos de política no ocidente nos dias de hoje, parte do pensamento dos filósofos gregos da antiguidade. Platão deixou-nos algumas idéias marcantes sobre o assunto, como por exemplo a idéia de que política não é arte ou técnica e sim uma ciência que orienta e dirige as práticas políticas. Já Aristóteles 
dizia que a política é a arte de igualar os desiguais e que "O homem é um animal naturalmente político". Os pensadores antigos partiam de pontos de vista diferentes para definir políticas, porém ambos a consideravam uma forma superior de vida (CHAUI, 2007).

Da antiguidade até os tempos atuais, muita coisa foi escrita sobre política. Neste trabalho vamos pensar a política como propõem Hannah Arendt, Foucault e Claude Lefort:

política é a criação de instituições sociais múltiplas nas quais uma sociedade se representa a si mesma, se reconhece e se oculta de si mesma, se efetua e trabalha sobre si mesma, transformando-se temporariamente. Ou seja, política não é só instituição do social mas também ação histórica (CHAUI, 2007, p. 33-34).

Na pós-modernidade estamos sofrendo o que alguns autores (CHAUI, 2007; NOVAES, 2007; SILVA, 2007; WOLF, 2007) chamam de "esquecimento da política", advindo principalmente do esquecimento da coisa pública em proveito do particular, ou ainda, da preocupação consigo próprio contra a preocupação com a pólis. É nesse contexto que Francis Woof (2007, p. 79) afirma que "o maior perigo para a democracia é o esquecimento pelo povo de que a política depende dele, que ela depende de todos nós". Ou seja, estamos lidando com uma concepção de política que se opõe à noção da política emanada unicamente a partir do Estado ou do governo.

Aspectos políticos vêm sendo estudados na área de Gestão Estratégica Pública e na busca de melhorias para o processo de elaboração e desenvolvimento de metodologias para análise de políticas públicas. Segundo Dagnino (2008, p. 89) esta análise leva em conta que "os aspectos políticos são inerentes ao processo de elaboração de políticas" e "a política envolve uma teia de decisões e o desenvolvimento de ações no tempo", ou seja, não pode ser considerada uma decisão isolada. Dentro dessa abordagem, são evidenciadas as distinções entre política e decisão e política e administração.

Ainda segundo o mesmo autor (DAGNINO, 2008), os estudos sobre os processos de elaboração de políticas públicas costumam ser divididos em 3 fases sucessivas: formulação, implementação e avaliação. A fase de formulação pode ser participativa ou autoritária, dependendo do âmbito do processo decisório em que é concebida. A implementação é feita mediante os órgão e mecanismos existentes ou 
criados na administração para esse fim. E a avaliação, por sua vez, é feita a partir da comparação do que foi planejado com os resultados e impactos decorrentes da implantação da política em questão.

Como vimos, é no momento de formulação que se estabelece a forma de participação. Quanto mais participativo, menos racional é o processo e quanto mais desequilibrada for a correlação de forças entre os atores, menor será a possibilidade de implementar uma política pública formulada de maneira participativa. Dagnino (2008, p. 135) alerta para o fato de estarmos num país em "que as políticas são geradas e implantadas em um ambiente marcado por uma grande desigualdade de poder, de capacidade de influência e de controle de recursos entre os diversos atores sociais."

Já vimos que há diferenças entre as possibilidades de participação individual e coletiva, que a primeira tem o cidadão como agente da ação individual e a segunda tem a organização como agente de ações coletivas. E mais: em função do agente, individual ou coletivo, as formas de participação e os resultados destas ações são bem distintas.

Vimos também que a partir da filosofia da ação proposta por Pierre Bourdieu, individualmente, a ação de um cidadão é baseada nas suas estruturas objetivas (campos) e nas suas estruturas incorporadas (habitus). Esta ação individual, em alguns casos, é caracterizada como uma ação empreendedora.

Cabe esclarecer que o termo empreendedor vem sendo amplamente empregado pela sociedade nos dias de hoje, porém, segundo Peter Drucker, foi o economista Jean-Baptiste Say quem introduziu o termo para caracterizar aquele indivíduo que, por meio de suas ações, muda os recursos econômicos de uma área de baixa produtividade para uma área de maior produtividade e maiores lucros. Drucker transporta esse conceito para a área social ao identificar o agente individual que modifica a capacidade de atuação da sociedade como um empreendedor social. (DRUCKER apud BORNSTEIN, 2006).

Buford ressalta que os empreendedores sociais possuem uma orientação para os resultados, tendendo a "operar fora da linha filantrópica e sob o radar da mídia". Identifica o empreendedor social como àquele agente que

transforma processos no setor social, também com a perspectiva de extrair um rendimento maior. Aqui, no entanto, o 'produto' não é nem uma mercadoria nem um serviço (como nos negócios), nem uma 
regulamentação (como no governo), mas um ser humano transformado (BUFORD, 1998, p. 52)

Já as ações coletivas estão no campo das organizações, sejam elas movimentos sociais, redes sociais, organizações civis, empresas privadas ou o Estado.

Os movimentos sociais caracterizam-se por serem orientados no sentido de defender direitos, muitas vezes mediados por partidos políticos e combinam lutas sociais com as práticas institucionais de participação. No Brasil e no mundo temos vários exemplos de movimentos sociais: movimento sindical, operário, indígena, feminista, em defesa dos sem terra, entre tantos outros. Silvio Caccia Bava esclarece que, apesar das diferenças entre esses movimentos, todos expressam "a incapacidade do sistema político absorver as demandas da população, que passa de uma posição de resistência passiva para a mobilização", exigindo rupturas, desafiando os governantes, criando novos arranjos organizacionais e, acima de tudo, "politizando o social e socializando a política." (CACCIA BAVA, 2005, p. 13).

Ao discutir o papel dos movimentos sociais, Giddens (1991, p. 158) afirma que apesar da importância difusa na vida social moderna, essa modalidade de engajamento radical "fornece pautas para potenciais transformações futuras."

As redes sociais, conforme o próprio nome indica, são entrelaçamentos de pessoas e organizações, por onde circula um fluxo contínuo de informações. A Rede de Informação para o Terceiro Setor (RITS) as caracteriza como "estruturas flexíveis e cadenciadas" que

se estabelecem por relações horizontais, interconexas e em dinâmicas que supõem o trabalho colaborativo e participativo. As redes se sustentam pela vontade e afinidade de seus integrantes, caracterizando-se como um significativo recurso organizacional, tanto para as relações pessoais quanto para a estruturação social (REDE DE INFORMAÇÃO O TERCEIRO SETOR, [2007?]).

As organizações da sociedade civil diferenciam-se dos movimentos e das redes por terem uma estrutura organizacional formal. Diferenciam-se também do Estado e das empresas por se caracterizarem como instituições não governamentais sem fins lucrativos. O chamado Terceiro Setor é constituído por esse grupo de organizações. Existe hoje uma infinidade de organizações da sociedade civil, as quais poderíamos dividir em duas grandes categorias segundo o enfoque de suas 
ações: 1) aquelas com enfoque participativo que privilegiam o pensamento crítico e o engajamento do indivíduo num projeto social coletivo, e 2) aquelas com enfoque assistencialista e filantrópico, que tende a criar uma cultura de dependência ou de pura adesão.

As empresas, por sua vez, são organizações que visam lucro e, nos tempos de pós-modernidade, têm colaborado sobremaneira para ampliar o que Giddens (1991), denominou como "desalojamento do sistema social". Sevcenko, ao explicar as mudanças ocorridas em função da globalização, evidência esta questão da seguinte forma:

As grandes empresas adquiriram tal poder de mobilidade, redução de mão-de-obra e capacidade de negociação - podendo deslocar suas plantas para qualquer lugar onde paguem os menores salários, os menores impostos e recebam os maiores incentivos -, que tanto a sociedade como o Estado se tornaram reféns. O tripé que sustentava a sociedade democrática moderna foi quebrado (SEVCENKO, 2001, p. 31).

Tendo em vista a necessidade dessas organizações se adaptarem às suas realidades e até mesmo sobreviverem, surge a chamada "empresa-cidadã", onde a responsabilidade social passa a ter um peso cada vez maior para o conjunto de agentes individuais e coletivos que se relacionam com ela, seja este agente interno ou externo à empresa.

Nos dias de hoje vemos as empresas ultrapassando o pensamento do lucro a qualquer custo e começando a se reconhecer dentro de um sistema social formado por grupos de interesses interdependentes representados pelos clientes, funcionários, fornecedores, Estado, sociedade civil e pelos próprios investidores. É a empresa vista não mais somente como um negócio, mas também como parte da sociedade e como instrumento de desenvolvimento social. Essas empresas querem também ser reconhecidas como instituições socialmente responsáveis, comprometendo-se com o desenvolvimento da comunidade em que atuam e indo além do pensamento filantrópico, pois, afinal, trazem a postura empreendedora para o ambiente social.

Diferentemente da empresa, o Estado é a organização pública que deve ser capaz de regular as relações entre os agentes individuais e os agentes coletivos, de forma a representar os interesses da sociedade. O conceito de Estado vem das idéias de Platão sobre a pólis ou comunidade política. Segundo Platão, a 
comunidade política se distingue da família ou da vida social pelo tipo de poder. $\mathrm{Na}$ pólis estamos tratando do poder político que é público, definido por leis e exercido entre os iguais (CHAUI, 2002).

Teoricamente, os Estados Nacionais são soberanos, distinguem-se pela sua Constituição e pelo território que ocupam; porém, como bem alerta Ladislau Dowbor, está ocorrendo

uma nova hierarquização dos espaços, segundo as diferentes atividades, envolvendo tanto globalização como formação de blocos, fragilização do Estado-nação, surgimento de espaços sub-nacionais fracionados de diversas formas, transformação do papel das metrópoles, reforço do papel das cidades, e uma gradual reconstituição dos espaços comunitários desarticulados por um século e meio de capitalismo (DOWBOR, 1995, p. 1, grifo do autor).

O mesmo autor defende a idéia de se repensar o papel do Estado-Nação na hierarquia dos espaços sociais, tendo em vista que "situações complexas e diferenciadas, e que se modificam rapidamente, exigem muito mais participação dos atores sociais afetados pelas políticas." (DOWBOR, 1995, p. 4).

No período pós Revolução Científico-Tecnológica, até os anos de 1970, as análises sociais sobre o contexto mundial nos mostram que os Estados Nacionais exerciam maior controle sobre a economia e sobre as grandes corporações responsabilizando-se pela redistribuição de recursos para os setores carentes da sociedade. Esse sistema é o chamado "Estado de bem-estar social", que, apoiado por organizações da sociedade civil, exercia um controle mais equilibrado do processo de desenvolvimento social.

No Brasil, assim como em outros países do Terceiro Mundo, a história desse mesmo período é um pouco diferente: enquanto o mundo caminhava no sentido de unir forças para diminuir as desigualdades sociais, o Estado brasileiro não fez a sua parte, ou seja, as "reformas civilizatórias do capitalismo na terra, no tributo e no social." (POCHMANN, 2003, p. 17). Para agravar ainda mais essa situação, o Estado agiu como repressor dos movimentos e organizações da sociedade civil que atuavam na defesa dos direitos do povo. As conseqüências desta prática política foi o esgarçamento do tecido social, identificado na pobreza generalizada da população, decorrente da carência de oportunidades de trabalho e de acesso à saúde, à justiça, à educação, à cultura e a tantos outros direitos sociais básicos. 
Segundo Pochmann (2003), essa situação piora ainda mais a partir dos anos de 1980 quando o país para de crescer em função dos impactos gerados pelas políticas de corte neoliberal, ou seja, o Estado consegue ampliar ainda mais a exclusão no país. É nesse contexto que Milton Santos (2000, p. 30) diz que "há países mais permissivos e países menos permissivos. O Brasil é um país permissivo." Santos afirma ainda que

A retirada do Estado do processo de regulação da economia, dada como sendo um benefício para a sociedade, está, de fato, relacionada com a possibilidade de a empresa comandar a sociedade, porque é ela que acaba comandando a vida social, com o apoio das instituições internacionais e, em certos casos, como no Brasil, também com o apoio do Estado [...] O mercado é que regula e faz política, por meio de terceiros setores, ONGs subordinadas, empresas pseudo-sociais curiosamente elogiadas pelo Estado e até por certas igrejas (SANTOS, 2000, p. 30).

Sob o ponto de vista do comunitarismo, Myrthes Macedo apresenta uma contribuição que complementa a discussão sobre as políticas sociais públicas no Brasil. A autora inicia seu artigo lembrando que, se nos países desenvolvidos as reflexões que se fazem sobre a comunidade estão associadas à questão do risco social, no Brasil, o debate

sobre comunidade, no campo da intervenção prática, está associado ao crescimento do chamado Terceiro Setor que tem determinado o esvaziamento do conteúdo político no entendimento do conceito de sociedade civil (MACEDO, 2005).

Macedo recorda a importância que teve a ação comunitária a partir de 1964 para a harmonia do sistema político imposto à época. Naquele momento, a comunidade era vista como um todo regido pelo consenso. Mais tarde, já nos anos de 1970 e 1980, deu-se o crescimento das Comunidades Eclesiais de Base da Igreja Católica, onde ganharam espaços as ações locais por meio de intervenções religiosas e governamentais. Ressalta também o impacto do processo de reordenamento das políticas sociais brasileiras, sob o marco neoliberal, a partir da década de 1990, com a negação do papel do Estado no projeto de proteção social. Somando-se a isso o crescimento acentuado das desigualdades sociais, chega-se à constituição 
de uma lógica de intervenção estatal norteada por uma estratégia de ação social despolitizada e consubstanciada por uma noção moral de responsabilidade, ditada como dever de solidariedade em relação ao mais pobres (MACEDO, 2005).

Apesar da força significativa das intervenções religiosas naquele momento, cabe lembrar que é também a partir dos anos 1990 que governos locais, apoiados por movimentos sociais, criaram experiências de sucesso, como, por exemplo, o orçamento participativo e as conferências das cidades. Essas formas de governo marcaram a retomada do processo democrático no país e serviu de exemplo para demonstrar a importância da contribuição da sociedade no processo político democrático.

A ampliação da participação é defendida por todos aqueles que acreditam na possibilidade de criação de um Estado de Direito e, hoje, a necessidade de articular os movimentos sociais, as organizações da sociedade civil e os governos locais é vista como o caminho para a reconstrução de um Estado regulador.

A complexidade que se apresenta nos leva a crer que a melhor forma de potencializar as práticas sociais de interesse coletivo ou público é por meio da articulação inteligente dos diversos agentes individuais e coletivos, dentro de uma visão horizontal e inter-relacionada. Porém, isso só é possível a partir da ação reguladora do Estado e da participação da sociedade na construção das políticas públicas. Nesse sentido, Ladislau Dowbor (1995, p. 9) ressalta a necessidade da redefinição da cidadania e das instituições "para que espaços participativos coincidam com as instancias de decisões significativas."

$\mathrm{O}$ autor, que escreveu vários estudos sobre as questões que envolvem o desenvolvimento local, apresenta o conceito de impotência institucional para caracterizar a perda de governabilidade na administração pública e esclarece que isto se dá principalmente pelo fato de que os diversos agentes sociais que definem as políticas públicas, em geral estão desarticulados e a solução para está questão é a criação de espaços de elaboração de consenso (DOWBOR, 1994).

Para o autor, no entanto, as políticas públicas nacionais são muito importantes. Dentro da perspectiva de ampliar a participação da sociedade na construção das mesmas e tendo em vista a dimensão continental e a diversidade econômica, social e cultural que caracteriza o Brasil, as políticas públicas locais 
devem ser valorizadas. Lembra, ainda, que a descentralização dos recursos amplia as possibilidades de participação direta da população local:

O Brasil acumulou nas últimas décadas uma base muito significativa de experiência de organização participativa. A fragilidade não está nas iniciativas, mas na sua dispersão, pouco apoio e mau aproveitamento [...] Estamos na era das parcerias, da responsabilidade social das empresas, das articulações entre as diferentes esferas da administração pública. As novas tecnologias da informação permitem que estas iniciativas sejam coordenadas de maneira flexível e dinâmica. Mas precisa haver esta visão de conjunto capaz de transformar dispersão em sinergia (DOWBOR, 2006, p. 17).

É nesse sentido que a sociedade civil organizada, preocupada e ávida por participar, desenvolveu uma proposta de Política nacional de apoio ao desenvolvimento local, baseada em experiências reais e entregue ao Presidente da República como uma agenda complementar aos esforços que já vêm sendo desenvolvidos na dinamização da base da sociedade. O diferencial, nesse caso, apresenta-se no reconhecimento da capacidade de auto-organização local, da riqueza do capital social, das dinâmicas participativas e do sentimento de apropriação do conjunto do processo pela comunidade (PROJETO, 2006).

A partir dos conceitos e estudos apresentados sobre a sociedade civil e as políticas públicas, entendemos que as praticas sociais e políticas, individualizadas e isoladas, colaboram para a desarticulação e fragmentação da sociedade, ampliando o processo de exclusão social. Fica também evidente que as políticas públicas de qualidade, criadas com base no interesse público e não no interesse privado, geram um sistema de apoio às iniciativas dos diversos agentes sociais, fomentando a apropriação local dos processos de desenvolvimento. Portanto, estas mesmas políticas não podem ser construídas somente de cima para baixo, por pessoas ou instituições que não conhecem efetivamente as realidades que enfrentam, ou, ainda, somente de baixo para cima, por pessoas desprovidas de apoio institucional. Não podem, tampouco, ser criadas com o foco no lucro da empresa privada. 


\section{BIBLIOTECAS COMUNITÁRIAS}

Uma verdadeira viagem de descobrimento não é encontrar novas terras, mas ter um olhar novo. Marcel Proust

Hoje, no Brasil, as bibliotecas, de modo geral, enfrentam uma situação adversa. Por um lado, podem atuar como um espaço estratégico para a implantação de políticas públicas de inclusão social e cultural. E, por esse motivo, as bibliotecas públicas, especialmente, têm a grande oportunidade de se fortalecer e, agregando as novas tecnologias, constituir efetivamente ambientes públicos colaborativos, transformadores e fundamentalmente culturais, caminhando no sentido de incorporar os conceitos inovadores propostos por Jack Maness (2007) para a Biblioteca 2.0.

É a partir da WEB 2.0 que surge o conceito da "Biblioteca 2.0", uma biblioteca que "pode parecer muito mais com uma interface de rede social". Esta mudança é paradigmática na Biblioteconomia, pois propõe que as bibliotecas abram "não somente acesso aos seus catálogos e coleções, mas acesso ao seu controle [...] e que foquem menos em estoques de sistemas seguros e mais em sistemas de descobertas colaborativas." (MANESS, 2007, p. 49).

Por outro lado, acreditamos que, em função das formas de ação dos profissionais que atuam em bibliotecas públicas, somada à imagem distante, rígida $\mathrm{e}$ sóbria que se criou para esse tipo de biblioteca, esse espaço ficou à margem da sociedade, se enfraquecendo e se isolando nos seus limites físicos e burocráticos. Segundo Milanesi (2002, p. 47) as bibliotecas públicas perderam

a idéia da informação pública [e seguiram] o trajeto rumo aos currículos escolares e, por isso, entre outros motivos, deixaram de lado a população. [...] Com isso, o que seria público transformou-se em escolar. O público ficou com o rádio e a televisão como fontes de informação.

Paralelamente a essa situação, acompanhamos diariamente na mídia a divulgação da criação de inúmeras bibliotecas comunitárias pelo país. Bibliotecas que surgem como práticas espontâneas, idealizadas e implementadas por agentes individuais ou coletivos; cidadãos comuns, com ou sem instrução formal, com ou sem apoio institucional. Surgem normalmente em lugares periféricos, em função da dificuldade de acesso aos bens culturais e da total ausência do Estado. 
Esses novos espaços de leitura e informação, em sua maioria, são criados por pessoas que não estão vinculadas à área de Biblioteconomia e Ciência da Informação e objetivam a reunião de uma coleção de livros que possibilite, principalmente às crianças e aos jovens, o acesso ao livro e à leitura.

A antropóloga Michèle Petit, em sua pesquisa sobre os jovens e a leitura, nos dá referencial para entendermos melhor esse processo. Segundo a autora, a leitura de livros dá aos jovens

algumas vantagens específicas que a distingue de outras formas de lazer. Compreendemos que por meio da leitura, mesmo esporádica, podem estar mais preparados para resistir aos processos de marginalização. Compreendemos que ela os ajuda a se construir, a imaginar outras possibilidades, a sonhar. A encontrar um sentido. A encontrar mobilidade no tabuleiro social. A encontrar a distância que dá sentido ao humor. $E$ a pensar, nesses tempos em que 0 pensamento se faz raro (PETIT, 2008, p. 19).

De modo geral, percebemos a disposição dos idealizadores desses projetos em apresentar a biblioteca comunitária como algo diferente da biblioteca pública, vinculada à esfera governamental, almejando constituir bibliotecas que tenham a cara de suas comunidades, que sejam espaços de acolhimento e de convivência e que tenham suas ações e serviços organizados com base na realidade $e$ conhecimento locais. A proposta dessas bibliotecas se assemelha muito às de Victor Flusser sobre aquilo que o autor (1980, p. 137) considera ser a "biblioteca verdadeiramente pública": aquela que não é implantada, mas que "surge de um processo de emergência cultural".

Se considerarmos que aqueles que lideram a constituição desses espaços são membros da própria comunidade, podemos inferir que eles têm a exata dimensão do valor do conhecimento e o quanto este pode definir a sua posição na sociedade; porém, talvez não tenham instrumentos suficientes e um sistema de apoio para agir de forma transformadora. Nesses casos, assim como suas comunidades, essas bibliotecas estão à margem da sociedade; porém, diferentemente das bibliotecas públicas, são legitimadas pela comunidade, pois nesses espaços as pessoas que fazem parte da comunidade se reconhecem e se identificam. Exemplo disso são as duas bibliotecas, pública e comunitária, localizadas no bairro de Pinheiros, na cidade de São Paulo. A Biblioteca Pública Alceu Amoroso Lima, legalmente criada pelo governo municipal vem ao longo dos 
últimos anos perdendo seus usuários, enquanto a Biblioteca Comunitária Ler é Preciso da Coopamare, criada pelos membros de uma cooperativa de catadores de lixo e legitimada por seus integrantes, tem sua utilização continuamente ampliada.

É interessante perceber que a biblioteca comunitária surge como um poder subversivo de um coletivo, uma forma de resistência contra-hegemônica, de quase enfrentamento social, numa nova realidade, que escapa das medidas e das categorias descritivas existentes, passando praticamente despercebida pela academia. Para nós, esse fato confirma a idéia de Milton Santos, de que a base da ação reativa é o espaço compartilhado no cotidiano (SANTOS apud DOWBOR, 1995, p. 8).

De forma empírica e criativa estão trabalhando no empoderamento da sua comunidade. E, nesse sentido, o grande desafio desses espaços é trabalhar com a informação pública, que é um dos campos mais complexos, pois o público é tão heterogêneo quanto a informação (MILANESI, 2002, p. 76). Vale esclarecer que o termo "empoderamento" é utilizado aqui como um neologismo que serve para exprimir a idéia de poder como força para a obtenção de meios para mudar fatos e costumes que causam as desigualdades.

Objetivamente, essas bibliotecas devem criar mecanismos para colaborar no desenvolvimento da sua comunidade, potencializando os próprios talentos dos indivíduos e das comunidades, constituindo-se como espaços públicos voltados para a emancipação, onde a prática cidadã possa aflorar de forma inovadora, criativa e propositiva.

\subsection{O CONCEITO E O EMPREGO DO TERMO}

A linguagem, como uma das formas de expressão da humanidade, é considerada um sistema de comunicação criado pelo homem e que tem como princípio a sua constante reconstrução. À medida que a sociedade se transforma, percebemos na linguagem o surgimento de novos termos e expressões. Algumas áreas do conhecimento, como a Lingüística e a Semiótica, dedicam seus estudos a acompanhar de forma rigorosa esse fenômeno. Se, por um lado, podemos dizer que essa flexibilidade e reconstrução permanente são ricas, pois estão sempre criando 
novos sentidos para a vida e para as relações, por outro lado, esse fato muitas vezes causa problemas sérios de sentido e compreensão do mundo.

Só para se ter uma noção das dificuldades que encontramos, podemos citar o caso da própria Ciência da Informação, em que nossos problemas em relação à linguagem se iniciam na definição do termo "informação", o que passa a ser um grande obstáculo até mesmo para a área se firmar no mundo científico. Esclarecemos que neste trabalho o termo é entendido como uma unidade de comunicação que representa o conceito.

Com relação ao termo "biblioteca comunitária", percebemos a dificuldade na sua definição, pois ele vem sendo empregado, pela sociedade em geral, como sinônimo de biblioteca pública e biblioteca popular, sendo que o mesmo ocorre no contexto acadêmico. Partindo do princípio de que é importante a utilização de termos claros e significativos dentro de uma área de pesquisa, acreditamos ser importante fazer uma reflexão sobre suas formas de emprego e sua relação com os tipos de bibliotecas caracterizados pela Biblioteconomia.

Apesar da escassez de literatura sobre o assunto, não podemos dizer que o emprego do termo biblioteca comunitária seja recente. Na literatura estrangeira, identificamos autores utilizando essa denominação para se referir àquelas bibliotecas que têm um trabalho ativo junto a sua comunidade. $\mathrm{Na}$ maioria dos casos, essas bibliotecas poderiam ser caracterizadas, segundo a tipologia biblioteconômica, como bibliotecas públicas, pois possuem o mesmo objetivo, ou seja, democratizar o acesso ao livro e à informação para a comunidade local. $\mathrm{O}$ mesmo acontece com o uso do termo biblioteca popular.

$\mathrm{Na}$ literatura nacional, encontramos poucos trabalhos que tratam do assunto. Aparentemente, o fato dessas bibliotecas surgirem de modo espontâneo na comunidade não colabora para ampliar o registro sobre essas ações.

Segundo Almeida Junior (1997), o termo biblioteca comunitária é citado pela primeira vez na literatura brasileira da área em 1978, por Carminda Nogueira de Castro Ferreira, ao se referir à experiência americana do início do século passado, que tratava da integração da biblioteca pública com a escolar.

Todêska Badke apresenta um dos primeiros relatos na literatura nacional sobre constituição de bibliotecas comunitárias, o caso da biblioteca do Parque Residencial Laranjeiras, localizado no município da Serra, ao Norte da Grande Vitória, no Espírito Santo. Apesar de afirmar que é uma biblioteca comunitária, essa 
experiência é denominada pela autora como uma biblioteca popular, pois considera popular "o que é feito pelo povo e para o povo, compreendendo por isso sua efetiva participação" (BADKE, 1984, p. 18).

Ainda segundo Badke,

A biblioteca popular caracteriza-se por surgir da vontade, necessidade e trabalho de uma comunidade; ela emerge do esforço de pessoas que lutam juntas, tendo como principal objetivo realizar um trabalho baseado na proposta de transformar a realidade vigente. Estas bibliotecas, normalmente, aparecem em bairros onde vivem pessoas de uma classe social menos favorecida, com experiências de lutas sociais (BADKE, 1984, p. 18).

Diferentemente, Gorosito López (2003) apresenta-nos a experiência da instalação de uma biblioteca comunitária no povoado "18 de Septiembre", da cidade de San Fernando, Chile, cuja idéia nasceu da luta do povo contra a exclusão social e como reivindicação do direito à informação. O uso do termo biblioteca comunitária pelo autor e pelo grupo idealizador do projeto é empregado com o mesmo significado que Todeska Badke dá ao termo biblioteca popular - do povo e para o povo.

O mesmo se dá no trabalho de Geraldo Prado (2004), ao apresentar uma análise e avaliação dos impactos gerados a partir da experiência de criação da Biblioteca Comunitária Maria das Neves Prado, no pequeno povoado de São José do Paiaiá, no município de Nova Soure, região do semi-árido baiano. Nesse caso, a biblioteca foi criada pelo autor, porém a partir de ações pedagógicas, foi sendo incorporada pela comunidade. É importante destacar que a população desta cidade, em sua grande maioria, nunca tinha tido acesso a um livro.

Marisa S. de Jesus (2007), em seu texto Implantação de bibliotecas comunitárias nos municípios do Estado da Bahia, faz uma distinção entre a biblioteca pública e a comunitária, apontando-as como um "fenômeno em construção" e defende a parceria com o poder público como uma alternativa para a consolidação desses projetos. Ao final, apresenta uma relação com dados para contato de 11 experiências naquela região.

Em 2005, o professor Aziz Ab'Sáber publicou uma série de 3 textos sobre o tema bibliotecas comunitárias na revista Scientific American Brasil. O autor, que há anos colabora com a criação de bibliotecas comunitárias na cidade de São Paulo, vê 
esses projetos como espaços complementares à formação escolar. Segundo Ab’Sáber (2005c, p. 98),

no momento em que muitas bibliotecas de bairros de grandes cidades fracassaram nesses objetivos (apesar dos edifícios bonitos que as asilam), os pequenos estoques de livros reunidos em situações comunitárias, acrescidas por telecentros, podem constituir exemplos de estratégias culturais para menores e adolescentes ávidos por atenção e atividades laboratoriais (computação e internet).

Almeida e Machado (2006), ao apresentar um relato sobre o encontro "Bibliotecas comunitárias e populares: diálogos com a universidade", iniciam seu texto contextualizando e evidenciando as dificuldades no emprego do termo. Todas as experiências apresentadas naquele evento são identificadas como bibliotecas comunitárias e são evidenciadas como resultado de iniciativas autônomas, quando muito apoiadas por agentes sociais que não são da comunidade local e sim de organizações do Terceiro Setor. Fazem parte desse relato as seguintes experiências: Biblioteca Comunitária do Projeto Casulo, Biblioteca Comunitária "Livro-Pra-Quê-Te-Quero", Biblioteca Comunitária de Heliópolis, Biblioteca Comunitária Solano Trindade e Biblioteca Comunitária Zumaluma.

As autoras destacam os fatores de sucesso identificados nas iniciativas estudadas:

O comprometimento com o projeto, a ponto de transformarem em uma causa o objetivo de incentivar a leitura e dar acesso à informação; em decorrência desse comprometimento, a consciência crítica e política de seu papel por parte das lideranças que se formam; o conhecimento do potencial transformador do projeto e a importância da participação e do envolvimento da comunidade; a importância da negociação seja ela com os moradores, com o poder público (escolas, órgãos de segurança pública etc) ou com parceiros da iniciativa privada ou do terceiro setor (ALMEIDA; MACHADO, 2006, grifo do autor).

Cabe destacar o trabalho sobre a história das bibliotecas comunitárias na Escócia, apresentado por John Crawford, no 68th IFLA Council and General Conference de 2002. O autor esclarece que esses espaços eram também conhecidos como "library society" pelo fato dos membros ou associados se inscreverem e pagarem taxas como num clube. Segundo Crawford a origem das bibliotecas comunitárias na Escócia data do século 17 e sua concepção ficou enraizada na cultura e valores intelectuais do país, de maneira que até hoje as 
bibliotecas públicas conservam um forte cunho democrático, visto que são administradas a partir de comitês compostos por membros da comunidade local. $O$ autor finaliza seu trabalho afirmando que foi o legado das bibliotecas comunitárias que deu à Escócia condição de ser o primeiro país no mundo a ter políticas públicas nacionais para as bibliotecas públicas. Nesse caso, fica evidente que o termo é empregado para identificar um tipo específico de bibliotecas que tinham características diferentes das atuais bibliotecas públicas.

No entanto, na maioria dos relatos de experiências em países desenvolvidos, tais como Estados Unidos da América (COLSON, 1975; SUAIDEN, 1995), Irlanda (MARTIN, 1975), Inglaterra (FINNEGAN, 1975), Austrália (THOMAS, 1975) e mesmo Suécia, (SUAIDEN, 1995) de modo geral os autores utilizam o termo bibliotecas comunitárias (Community Library) para qualificar uma biblioteca pública, ou seja, vinculada a órgãos públicos e localizada em bairro periférico de grandes centros urbanos ou na zona rural. É o caso das experiências descritas por William Martin (1975) acerca das bibliotecas nas regiões periféricas da cidade de Belfast, na Irlanda. As abordagens desses relatos são, em sua maioria, referentes ao trabalho, organização e implantação de serviços informacionais e de leitura para comunidades específicas, caracterizadas como excluídas ou em situação de risco, tais como comunidades de presidiários, formadas por pessoas com necessidades especiais, de desempregados, de moradores de rua, de iletrados e de imigrantes.

Fazendo uma comparação entre relatos atuais e históricos, podemos concluir que o conceito de biblioteca comunitária utilizado nos dias de hoje nos países chamados de primeiro mundo é diferente daquele usado por Crawford sobre o surgimento das bibliotecas na Escócia. Temos notícias da existência de bibliotecas comunitárias na Europa em geral, advindas de ações de grupos de imigrantes que, em função das dificuldades lingüísticas e da necessidade de preservar suas culturas, criam suas bibliotecas comunitárias, porém, não encontramos relatos técnicos que pudessem validar cientificamente esta questão.

Retomando para a esfera nacional, recentemente percebemos que a Universidade vem estimulando a produção de Trabalhos de Conclusão de Curso (TCCs) sobre o assunto, o que demonstra uma crescente curiosidade por parte de jovens alunos de cursos de Biblioteconomia em entender qual o papel das bibliotecas comunitárias na democratização da informação, nos processos de desenvolvimento local e de transformação social. Vale destacar o trabalho de Célia 
Barbosa de Sá, que faz um estudo de caso das bibliotecas comunitárias da Associação Comunitária Monte Azul, na cidade de São Paulo. Nos TCCs analisados (FACCION JUNIOR, 2005; AMORIM, 2006; PUPPIN, 2008; SÁ, 2007; SILVA, 2008), ficou evidente a dificuldade dos alunos em relação à conceituação da biblioteca comunitária.

Até aqui tratamos o termo biblioteca comunitária no âmbito da linguagem natural, onde é comum as palavras apresentarem polissemia, homonímia e sinonímia. No âmbito da terminologia ou da linguagem artificial, fomos consultar os cabeçalhos de assunto ${ }^{2}$ da Library of Congress (LC) e da Biblioteca Nacional do Brasil (BN), com o objetivo de identificar qual a terminologia utilizada para classificar e recuperar estudos e casos que tratem do assunto bibliotecas comunitárias. Obtivemos o seguinte resultado:

$\checkmark$ no Subject Heading da Library of Congress:

\begin{tabular}{|c|}
\hline \multicolumn{1}{|c|}{ Community development libraries } \\
UF $\quad$ Libraries, Community development \\
BT $\quad$ Social science libraries \\
\hline Libraries and Community \\
UF $\quad$ Community and library \\
BT $\quad$ Community life \\
NT $\quad$ Libraries - Cultural programs - Libraries \\
\\
and adult education - National libraries \\
- Cultural programs \\
Public libraries - Administration - \\
Citizen participation \\
Public libraries - Cultural programs \\
Public relations - Libraries
\end{tabular}

Figura 1-2 - Cabeçalho de assunto LC Fonte: Subject Heading (LC)

\footnotetext{
${ }^{2}$ Símbolos usados para indicar as relações entre cabeçalhos de assunto:

UF-Used For = UP - Usado Por

BT - Broader Topic = TG - Termo Genérico

NT - Narrower Topic $=$ TE - Termo Específico

RT - Related Topc $=\quad$ TR - Termo Relacionado

AS - See also $\quad=\quad$ VT - Ver também
} 
$\checkmark$ A Biblioteca Nacional determina os seguintes termos para recuperar 0 assunto:

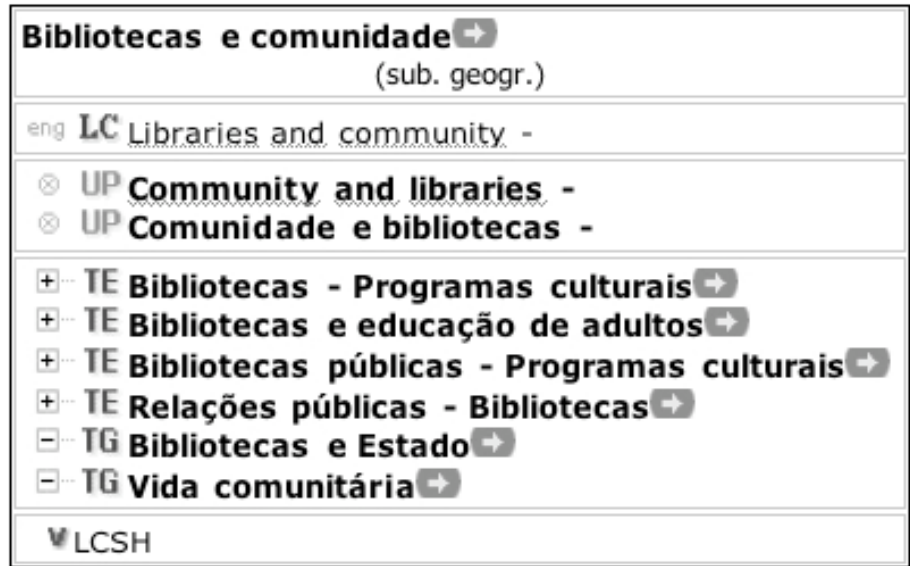

\begin{tabular}{|c|}
\hline $\begin{array}{c}\text { Bibliotecas e sociedade } \Rightarrow \\
\text { (sub. geogr.) }\end{array}$ \\
\hline eng LC Libraries and society - \\
\hline UP Sociedade e bibliotecas - \\
UP Society and libraries - \\
\hline+ TE Bibliotecas - Programas culturais $\Rightarrow$ ) \\
\hline$V_{\text {LCSH }}$ \\
\hline
\end{tabular}

Figura 3-4 - Cabeçalho de assunto da BN Fonte: catálogo online $(\mathrm{BN})$

Para a recuperação de estudos e relatos de casos sobre experiências de bibliotecas comunitárias, tanto na Library of Congress como na Biblioteca Nacional é utilizado o termo "bibliotecas e comunidades" o que nos faz concluir que o termo "biblioteca comunitária" não é endossado pela comunidade de especialistas na área terminológica.

Nos países desenvolvidos, é compreensível a adoção dessa terminologia, pois, como já vimos, os trabalhos publicados sobre o assunto tratam de ações implementadas por bibliotecas públicas para atender demandas da comunidade. No entanto, no Brasil o termo "biblioteca comunitária" seria mais adequado, tendo em vista o conceito que este carrega na cultura local. Porém, aparentemente, a Biblioteca Nacional, ao definir a terminologia nesse caso, optou, mais uma vez, por seguir o referencial Norte-Americano, ou seja, apenas traduziu os termos utilizados pela Library of Congress, desconsiderando as diferenças culturais.

Entendemos que o conceito de biblioteca comunitária, no Brasil remete a uma categoria de entidades que possui o mesmo significado, ou seja, espaços físicos 
abertos ao público local, de acesso à informação e às diversas formas de leitura, onde a ação cultural é fortemente implementada.

De modo geral, as bibliotecas atendem as demandas de suas comunidades e são caracterizadas por elas, ou seja, pelo seu público. A biblioteca universitária é criada por lei federal, independente de ser vinculada a uma instituição de ensino superior pública ou privada, atende prioritariamente a comunidade de docentes, estudantes e funcionários que a integram, enquanto que a biblioteca especializada está necessariamente atrelada a uma instituição e atende às demandas informacionais do grupo de técnicos e especialistas vinculados formalmente a essa instituição.

Esses dois tipos de bibliotecas estão ligados a comunidades discursivas que, segundo Swales (1990 apud NASCIMENTO; MARTELETO 2004), possuem metas comuns, mecanismos participativos, trocas de informação, estilos específicos, terminologia especializada e alto nível de especialização.

As bibliotecas públicas são espaços públicos. No Brasil são criadas por lei estaduais e municipais e possuem vínculo direto com um órgão governamental, Estado, Município ou Federação, os quais respondem por sua manutenção por meio de recursos humanos, financeiros e materiais. Atendem às demandas da população que reside ou freqüenta a região em que está localizada. São criadas para atender as necessidades informacionais de uma ou mais comunidades, ou seja, seu público é heterogêneo, o que significa que pode trabalhar com várias comunidades discursivas, as quais nem sempre possuem todas as características apresentadas por Swales, tais como alto nível de especialização, terminologia especializada, ou mecanismos participativos.

Nesse sentido, Milanesi ressalta a complexidade que envolve a questão do público:

Quanto maior for a homogeneidade, tanto de público quanto de informação, menos complexas são as ações para informar. Se ambos forem homogêneos, há um grau maior de facilidade para encontrar a informação certa para o usuário certo. No entanto, num outro extremo, se os dois forem heterogêneos, chega-se ao máximo de dificuldade (MILANESI, 2002, p. 76).

Dentro desse contexto, cabe destacar o fato da Biblioteca da Universidade Federal de São Carlos (UFSCar) utilizar por denominação o termo biblioteca 
comunitária. Segundo eles, esta opção se deu pelo fato de ser uma biblioteca aberta à comunidade local, ou seja, além de atender alunos, professores e funcionários, atende também a comunidade externa. Para nós isso é um exemplo de uso indevido do termo, visto que está se caracteriza prioritariamente como uma biblioteca universitária e tem, como todas as demais bibliotecas desse tipo, a função de oferecer serviços de extensão à comunidade. Nesse caso consideramos que houve uma inversão de valores, o que só colabora para vulgarizar o termo, desviar o foco e enfraquecer as ações da instituição.

Alguns estados e municípios brasileiros, com o objetivo de aproximar as bibliotecas públicas de suas comunidades, passaram a denominá-las como bibliotecas populares. É o caso, por exemplo, dos municípios do Rio de Janeiro e de Niterói.

Nesses casos, ao substituir pública por popular, parece-nos que o Estado espera, com isso, fazer com que o imaginário da sociedade capture esse termo e o incorpore ao espaço público da biblioteca, como uma qualidade de experiências sociais, políticas e culturais. No entanto, essas bibliotecas continuaram as mesmas, ou seja, as mudanças ficaram apenas no campo semântico e não foram suficientes para garantir a sua incorporação no campo da prática ou da ação. Nesse sentido, poderíamos concluir que essas mudanças são resultado de uma ação populista e não genuinamente popular. Para Marilena Chaui

a tradição populista, mais forte no final dos anos de 1950 e início de 1960, pretende que o órgão público de cultura tenha um papel pedagógico sobre as massas populares para, depois de transformála, devolvê-la em sua 'verdade verdadeira' ao 'povo' (CHAUI, 2006, p. 67).

Já a escolha do termo popular pela sociedade em geral provavelmente surja a partir de uma associação com o pensamento de Antonio Gramsci. O popular na cultura, segundo a perspectiva gramsciana, significa

[...] a transfiguração expressiva de realidades vividas, conhecidas, reconhecidas e identificáveis, cuja interpretação pelo intelectual, pelo artista e pelo povo coincide. Essa transfiguração pode ser realizada tanto pelos intelectuais 'que se identificam com o povo' como por aqueles que saem do próprio povo, na qualidade de seus intelectuais orgânicos (CHAUI, 2006, p. 20). 
Ao associar o popular à biblioteca, acreditamos que os autores e os atores responsáveis por esse tipo de projeto esperam elaborar uma outra idéia da biblioteca pública.

Almeida Junior (1997), em seu livro Bibliotecas Públicas e Bibliotecas Alternativas, resultado de sua dissertação de mestrado, apresenta um estudo caracterizando e identificando as diferenças entre a biblioteca pública, a biblioteca popular e a biblioteca comunitária. Nesse estudo, o autor parte do histórico do surgimento das bibliotecas públicas para fazer o paralelo com as novas iniciativas, por ele denominadas bibliotecas alternativas. No terceiro capítulo de seu livro, Almeida Junior extrai e discute as tentativas de definição do termo biblioteca comunitária apresentadas por alguns autores, tais como Ida Stumpf, Sarti, Guiraldelli e Vicentin, Todeska Badke e por fim, conclui que, em relação ao uso do termo na literatura, esse é usado como forma de amenizar as idéias que acompanhavam as propostas de bibliotecas populares. Quanto à tipologia, conclui que a biblioteca comunitária não pode ser caracterizada como um tipo diferente de biblioteca, pois, de modo geral, possui os mesmos objetivos e normalmente oferece os mesmos serviços que a biblioteca pública.

O adjetivo comunitário estaria sendo empregado com o intuito de destacar essa proposta de outras tantas existentes, tornando-a mais atraente, inclusive para a sociedade, que, em função dessa nova designação, pode imaginá-la tratando-se de uma instituição diferente da biblioteca pública sobre a qual já possui um estereótipo formado. Assim a biblioteca comunitária passaria para a sociedade, por uma nova entidade, não carregando preconceitos e idéias preconcebidas que prejudicariam sua atuação (ALMEIDA JUNIOR, 1997, p.107).

Desse modo, a partir da tipologia da área, entendemos os argumentos de Almeida Junior em relação à semelhança entre a proposta da biblioteca pública e da biblioteca comunitária, pois o autor estabelece sua reflexão a partir do espaço, do acervo, do público e dos serviços que a unidade informacional oferece. No entanto, se considerarmos outros aspectos, podemos identificar particularidades que as distinguem, tais como:

1. a forma de constituição: são bibliotecas criadas efetivamente pela e não para a comunidade, como resultado de uma ação cultural. 
2. a perspectiva comum do grupo em torno do combate à exclusão informacional como forma de luta pela igualdade e justiça social.

3. o processo de articulação local e o forte vínculo com a comunidade.

4. a referência espacial: estão, em geral, localizadas em regiões periféricas.

5. o fato de não serem instituições governamentais, ou com vinculação direta aos Municípios, Estados ou Federação.

Por essas particularidades, de forma complementar ao pensamento de Almeida Junior, consideramos que a biblioteca comunitária, como se apresenta hoje na sociedade brasileira, pode ser considerada um outro tipo de biblioteca, pois vem sendo criada seguindo os princípios da autonomia, da flexibilidade e da articulação local, o que amplia as possibilidades de atuação e de inserção na sociedade. Outro fator que nos leva a considerá-la diferente é pela forma de atuação estar muito mais ligada à ação cultural do que aos serviços de organização e tratamento da informação. Esses princípios podem ser considerados qualidades essenciais destas bibliotecas, os quais as diferenciam das demais, tornando-as únicas. Se retirados, destroem sua essência.

Em relação às bibliotecas populares, não podemos deixar de citar o estudo sociológico realizado por Gilda Verri (1996) sobre as bibliotecas populares da cidade de Recife, no período de 1930 a 1964. Segundo a autora, a idéia e criação de bibliotecas populares foi um projeto político das elites brasileiras, fortemente vinculado à concepção da Educação Popular da década de 1920. A autora destaca que Recife seguiu as experiências de bibliotecas populares defendidas pelo Rio de Janeiro, São Paulo e Belo Horizonte, que tinham como padrão o modelo americano.

Outra contribuição importante sobre o assunto é a pesquisa histórica realizada por Patrícia Raffaini (2001) sobre o Departamento de Cultura de São Paulo, suas políticas culturais e as ações dos intelectuais na época. A pesquisa restringe-se ao período entre 1935 a 1938, em que Mário de Andrade foi diretor do Departamento e nos apresenta o forte papel educativo implementado por ele com o objetivo de conscientizar e criar cidadãos transformadores da vida pública. Em relação às bibliotecas,

o projeto que deveria ser desenvolvido compreendia uma rede de bibliotecas: uma biblioteca central, voltada à pesquisa e não circulante; bibliotecas infantis; bibliotecas populares de bairro, em 
que a população poderia emprestar as mais diversas obras e uma biblioteca circulante montada em uma caminhonete adaptada (RAFFAINI, 2001, p. 67).

Nos dois trabalhos, fica claro que a biblioteca popular proposta na época referia-se às bibliotecas de bairro ou distritais. Hoje a cidade de São Paulo, possui um total de 81 bibliotecas públicas, incluindo as localizadas na região central da cidade - Mário de Andrade, Monteiro Lobato e Sérgio Milliet - e as de bairro, que incluem as bibliotecas dos Centros Educacionais Unificados (CEUs).

Parece-nos que o que Bauman (2003) diz sobre o significado e os sentimentos que o termo comunidade carrega são potencializados pelo termo biblioteca, já que este também opera no imaginário da sociedade como um espaço carregado de cultura. O termo comunidade é usado, nesse caso, como um qualificador para identificar espaços informacionais ou serviços de informação fortemente vinculados ou direcionados a grupos específicos dentro de um contexto de necessidades socioculturais.

Chaui (2006, p. 62), ao refletir sobre a expressão "nacional-popular", alerta para o fato de que "justamente porque os termos não cessam de ser definidos e articulados de maneiras diferentes em diferentes condições históricas, a imaginação ideológica procura fixá-la como se fossem entidades positivas". Acreditamos que, o mesmo se dá na opção pelo uso da denominação bibliotecas comunitárias: nesse caso, ele não carrega apenas significados e sentimentos, carrega também ideologias. O mesmo ocorre com "popular", também um termo qualificador para a biblioteca e usado para afirmar o desejo de trabalhar, ou seja, oferecer serviços, para várias camadas da população. Porém, em função do tempo, espaço e das ideologias, os grupos tendem a utilizar um ou outro termo qualificador.

Para nós, o emprego do termo biblioteca comunitária é mais apropriado para identificar o que consideramos ser empreendimentos sociais que surgem do desejo e da necessidade de um determinado grupo de pessoas em ter acesso ao livro, à informação e à prática da leitura, num real exercício de cidadania. Em outras palavras, podemos identificar as bibliotecas comunitárias como projetos vinculados a um grupo particular de pessoas, que têm como objetivo atender esse mesmo grupo, os quais possuem os mesmos problemas, os mesmos interesses e a sua própria cultura, seja esse um grupo de especialistas em paleontologia ou um grupo de moradores de uma comunidade considerada de risco. Estas pessoas ou grupos são 
agentes individuais ou coletivos que, por meio de práticas sociais, interferem numa realidade agindo de maneira transformadora.

Se encontramos pouca literatura sobre a biblioteca comunitária, o contrário se dá em relação à biblioteca pública. Esta é tema de estudo e análise por parte de pesquisadores há muitos anos. Muitos autores reconhecem o forte cunho ideológico que essas instituições transmitem. Vergueiro, por exemplo, em sua tese de doutorado, para discutir o desenvolvimento de coleções, apresenta a biblioteca pública como "instrumento a serviço da manutenção do status quo dominante na sociedade." (VERGUEIRO, 1990, p. 8).

Nesse sentido, Almeida Junior afirma que

[...] faz parte da essência da biblioteca pública a ambigüidade, a contradição. Mantida pelo Estado, preserva e reproduz as condições sociais que mantêm determinadas classes no poder [...] a biblioteca pública, historicamente, manteve-se, com maior intensidade, ao lado dos interesses das classes dominantes, tomando para si - talvez sem consciência clara dessa atitude - a responsabilidade de reproduzir aqueles interesses, em detrimento da população e colocando em risco sua imagem e função social junto a esse segmento da sociedade (ALMEIDA JUNIOR, 1997, p. 23).

Sarlo (2004) esclarece que as sociedades têm se caracterizado pela reprodução de desejos, mitos e condutas e o faz com a idéia de que a reprodução é um exercício de autonomia dos sujeitos.

No entanto, não podemos desconsiderar que a biblioteca pública, assim como a biblioteca comunitária, vêm cumprir uma função educadora e formadora e pretendem ser um instrumento de transformação social. Tanto uma como a outra, ao dar acesso à informação e à leitura, esperam contribuir e fomentar o desenvolvimento do pensamento crítico e a construção de novos conhecimentos, numa luta contra a crescente homogeneização cultural impregnada no clima da pósmodernidade, porém, algumas diferenças entre elas são aqui consideradas substanciais e, com base nos pressupostos e reflexões apresentados, somando-se a estes os resultados de pesquisas e estudos realizados por Macedo e Spinelli (1987), Cunali e Branco (2002) e Almeida e Machado (2006), elaboramos um quadro para melhor visualização dessas diferenças. 


\begin{tabular}{|c|c|c|}
\hline CARACTERÍSTICAS & BIBLIOTECAS PÚBLICAS & $\begin{array}{l}\text { BIBLIOTECAS } \\
\text { COMUNITÁRIAS }\end{array}$ \\
\hline Fundamentação & Projeto técnico ${ }^{3}$ & 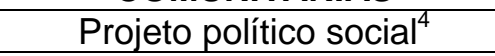 \\
\hline Legitimidade & Dada pelas leis & Dada pelo grupo \\
\hline Estrutura & $\begin{array}{l}\text { Vinculada a órgão } \\
\text { governamental }\end{array}$ & $\begin{array}{c}\text { Vinculada a um grupo de } \\
\text { pessoas, podendo ou não ser } \\
\text { parceira ou ter apoio de órgão } \\
\text { públicos e privados. }\end{array}$ \\
\hline Hierarquia & Rígida - altamente hierarquizada & Mínima - Flexível \\
\hline $\begin{array}{l}\text { Equipe Interna - } \\
\text { Constituição }\end{array}$ & $\begin{array}{l}\text { Funcionários da Administração } \\
\text { Pública, alocados no } \\
\text { equipamento } \\
\text { independentemente do seu } \\
\text { vínculo local. }\end{array}$ & Membros da comunidade \\
\hline $\begin{array}{l}\text { Equipe interna - } \\
\text { Postura }\end{array}$ & Dependência & Autonomia \\
\hline
\end{tabular}

Quadro 2 - Quadro comparativo entre Bibliotecas Públicas e Bibliotecas Comunitárias. Fonte: o autor (2008)

Nesse contexto, é importante que fique claro que a concepção adotada nesta pesquisa para o trabalho com bibliotecas comunitárias, leva em consideração os cinco aspectos acima apresentados e as define como sendo

um projeto social que tem por objetivo estabelecer-se como uma entidade autônoma, sem vínculo direto com instituições governamentais, articuladas com as instâncias públicas e privadas locais, lideradas por um grupo organizado de pessoas, com o objetivo comum de ampliar o acesso da comunidade à informação, à leitura e ao livro, com vistas a sua emancipação social.

\footnotetext{
${ }^{3} \mathrm{O}$ termo projeto técnico é aqui empregado levando em conta as considerações feitas por Francis Woff (2007, p. 73) onde o técnico refere-se a ações puramente administrativas e burocráticas que buscam soluções racionais e simples para problemas sociais. Por exemplo, as bibliotecas públicas no Brasil, definem seus horários utilizando um método puramente técnico - das 8 hs às $17 \mathrm{hs}$ de $2^{\mathrm{a}}$. a $6^{\mathrm{a}}$. feira.

${ }^{4} \mathrm{O}$ projeto político social é aqui usado no sentido de um projeto que prioriza as necessidades sociais na sua concepção. Neste caso, o exemplo acima teria que encontrar outras possibilidades de horário para atender a população que no horário comercial não pode freqüentar a biblioteca.
} 


\subsection{AS PRATICAS SOCIAIS E A BIBLIOTECONOMIA}

Não há palavra verdadeira que não seja práxis. Paulo Freire.

No início do século XIX, Antonio Panizzi, revolucionário italiano no exílio, que atuou como bibliotecário no Museu Britânico, na Inglaterra, já demonstrava sua preocupação social ao dedicar esforços no desenvolvimento de catálogos desse museu; segundo Battles (2003), para Panizzi o catálogo era considerado um instrumento de transformação social. Ele deixa isso claro ao afirmar, no seu relatório de 1836:

Eu quero que o estudante pobre tenha os mesmos recursos que 0 homem mais rico deste reino para satisfazer sua vontade de aprender, desenvolver atividades racionais, consultar autoridades nos diversos assuntos e aprofundar-se nas investigações mais intricadas. Acho que o governo tem a obrigação de dar a esse estudante a assistência mais generosa e desprendida possível. (PANIZZI apud BATTLES, 2003, p. 133).

Melvin Dewey, Paul Otlet e La Fountaine são referências, na Biblioteconomia moderna, de profissionais que atuaram e desenvolveram instrumentos de controle da informação com vistas a ampliar seu acesso dentro de um pensamos humanista e com uma função social, porém, não podemos esquecer que aquele era o momento da ciência moderna, totalmente baseada na estrutura do conhecimento, e mais, com o foco no controle e não na transferência da informação. O pensamento complexo e a concepção sistêmica do conhecimento não eram ainda considerados.

Ao discutir a concepção sistêmica do conhecimento e sua importância para a educação e o ensino, Morin (2004, p. 88) ressalta que esta demanda um pensamento:

$\checkmark$ que compreenda que o conhecimento das partes depende do conhecimento do todo e que o conhecimento do todo depende do conhecimento das partes;

$\checkmark$ que reconhece e examina os fenômenos multidimensionais, em vez de isolar, de maneira mutiladora, cada uma de suas dimensões;

$\checkmark$ que reconhece e trate as realidades, que são, concomitantemente solidárias e conflituosas (como a própria democracia, sistema que se alimenta de antagonismos e ao mesmo tempo os regula);

$\checkmark$ que respeite a diferença, enquanto reconhece a unicidade. 
A nosso ver, falta ao bibliotecário reflexão crítica sobre sua prática e isso se dá pelo fato do mesmo ser formado dentro de um conceito que Paulo Freire (2006, p.25) denominou de educação bancária. Nesta concepção, os educandos são considerados depósitos e tem a única obrigação de guardar e arquivar os comunicados feitos pelos professores, "não há criatividade, não há transfomação, não há saber [...] o 'saber' é uma doação dos que se julgam sábios aos que julgam nada saber".

Tecnicamente os alunos dos cursos de Biblioteconomia são orientados a criar e aperfeiçoar sistemas de organização, controle, conservação e disseminação de informação, de modo a garantir a preservação de documentos pelo maior tempo possível. No entanto, na maioria das escolas do país, descarta-se, nesta formação, o lado humanista, minimizando-se e às vezes até anulando o poder criador e crítico do educando.

Apesar do incentivo à leitura ser um dos objetivos mais importantes tanto da biblioteca pública como da escolar, a relação com os conteúdos escritos e os processos de leitura não são questões abordadas nos conteúdos programáticos dos cursos de Biblioteconomia. Esse fato afasta o bibliotecário de estudos aprofundados sobre o tema, inibindo o desenvolvimento de competências para enfrentar o desafio do incentivo à leitura em suas práticas cotidianas.

Entretanto, a formação acadêmica dá ao bibliotecário total condição para trabalhar exclusivamente para "uma seleta e elitizada classe social, que se utiliza da biblioteca e do bibliotecário, com seu consentimento e apoio, para manter seus privilégios e sua condição de dominante" (ALMEIDA JUNIOR, 1989), como sempre ocorreu na história da área. Ou seja; em sua maioria, os profissionais que vão atuar no mercado de trabalho não estão preparados para mediar a leitura, assim como, não estão preparados para interpretar e usar a informação como meio para se relacionar com o seu grupo ou para reconhecer a importância da relação do grupo com o seu passado, ou, ainda, para compreender a realidade presente da sua comunidade. Nesse sentido, cabe resgatar, mais uma vez Paulo Freire (2003, p. 38), ao afirmar que o mero reconhecimento de uma realidade "não conduz a nenhuma transformação da realidade objetiva, precisamente porque não é reconhecimento verdadeiro."

De modo geral, o bibliotecário é orientado a se relacionar com a comunidade de maneira muito superficial, normalmente utilizando técnicas de pesquisa junto aos 
usuários e à comunidade como ferramentas administrativas descoladas dos conceitos básicos da sociologia e da antropologia que permeiam essas técnicas. São os conhecidos estudos de usuários e de comunidades que, infelizmente, até hoje não passaram, em sua maioria, de coleta de dados estatísticos para fins de relatório, justamente pela falta da análise crítica dos resultados.

Quando muito, para inovar, o bibliotecário lança mão da aplicação de técnicas de marketing e, normalmente, acaba se restringindo apenas à "divulgação de serviços pré-concebidos para 'usuários genéricos', com intenção de promover o uso de acervo também pré-constituído." (FREITAS, 1995, p. 45).

Há mais de 20 anos Victor Flusser (1982) propôs a animação cultural como prática política para a profissão. O autor defendia uma formação que fosse dialógica e que permitisse a síntese contínua entre a teoria social, o conhecimento técnico e a prática profissional. Assim como ele, outros autores da área (ALMEIDA JUNIOR, 1989) vêm defendendo uma revisão dos conteúdos programáticos dos cursos de Biblioteconomia com vistas à incorporação de conteúdos humanistas.

Consideramos que os bibliotecários vêm, ao longo dos tempos, atuando de forma determinista, de maneira que a ordem e a organização superam o sujeito/cidadão. Entendemos, também, que a relação entre grupos seja fundamental para minimizar o processo crescente de exclusão e que a instituição biblioteca, para sobreviver e cumprir a sua missão, precisa de profissionais que valorizem 0 pensamento que distingue e que une, substituindo assim o pensamento redutor pelo pensamento complexo, ou seja, pelo pensamento construído em conjunto. Esse pensamento é resultado da proposta do teórico da complexidade, Edgar Morin (2004).

O resultado desse comportamento é que, apesar dos teóricos da área alardearem a mudança de paradigma da biblioteca vista como um espaço de armazenamento e conservação para um ambiente interativo e de disseminação da informação, na realidade, quando entramos em uma biblioteca pública, poucas mudanças percebemos - o caráter estático e conservado impera nesses espaços. Edgar Morin (2004, p. 81), ao discutir a evolução científica esclarece que o caráter conservador pode ser vital ou estéril num processo de desenvolvimento:

A conservação é vital quando significa salvaguarda e preservação, pois só se pode preparar um futuro salvando um passado, e estamos em um século onde múltiplas e poderosas forças de desintegração 
cultural estão em atividade. Mas a conservação é estéril quando é dogmática, cristalizada e rígida. Assim, a Sorbonne do século XVII condenou todos os avanços científicos de sua época, e, até o século seguinte, grande parte da ciência moderna foi formada fora das universidades.

Sem dúvida, a situação das bibliotecas é decorrente de inúmeros problemas, advindos não só da cultura e prática dos profissionais que atuam na área, mas também da histórica carência de políticas públicas para esses espaços. Porém, é fora de dúvida que mudanças significativas podem ocorrem a partir do momento em que esses espaços passem a fazer parte realmente da comunidade local, ou seja, quando, por um lado, os cidadãos e cidadãs se apropriarem desses espaços e, por outro, os bibliotecários que atuam na biblioteca estiverem dispostos a se integrar à comunidade com um novo olhar sobre esse grupo. Afinal, o bibliotecário, apesar de nesse momento estar desempenhando o papel de servidor público, não deve perder a dimensão do seu papel social, o de cidadão. Cabe aqui resgatar o alerta feito por Victor Flusser (1980, p.137): "ser bibliotecário em uma biblioteca verdadeiramente pública é desenvolver de uma maneira política a sua profissão.

É curioso constatar que a proposta feita há mais de 20 anos por Flusser, que caracterizava a biblioteca pública como uma organização passível de ser construída junto com a população, não foi incorporada as práticas biblioteconômicas. No entanto, o que Maness propõe hoje com a Biblioteca 2.0, utilizando a tecnologia de ponta, está totalmente impregnado do pensamento de Flusser.

Com base nos relatos de experiência e também da história da Biblioteconomia, tanto nos Estados Unidos da América (EUA) como na Inglaterra, percebemos que a preocupação dos bibliotecários com as questões sociais são antigas. Nesses países, os governos, ou as organizações da sociedade civil, criaram movimentos nacionais de luta contra a pobreza, o analfabetismo e a exclusão, e, os bibliotecários, bem ou mal, se organizaram e se envolveram nesses movimentos, na maioria das vezes apoiados por políticas públicas que garantiram sua participação. Apesar das guerras e das grandes recessões por que passaram muitos dos países do Norte, de modo geral, sempre houve uma reversão impulsionada pelos órgãos governamentais e as bibliotecas públicas, nesses momentos, somavam seus esforços criando serviços específicos para públicos considerados em situação de desvantagem - pobres, desempregados, pessoas com necessidades especiais, 
mulheres, crianças, homossexuais, enfim, grupos minoritários ou em condições de risco.

Os estudos sobre leitura feitos por Michèle Petit com jovens marginalizados na França indicam a importância que as bibliotecas públicas têm para esses grupos naquele país. Segundo a autora (PETIT, 2008, p. 11), "são nesses espaços que os jovens encontram um lugar estruturante, um profissional pronto para aconselhá-los e formas de sociabilidade" que os protegem das ruas. Petit identificou, também, que os rapazes são os que mais têm bloqueios em relação à leitura. "Os que conseguem ultrapassá-los o fazem graças a um encontro feliz" com um professor, com uma garota ou com uma bibliotecária.

É nesse sentido que muitas bibliotecas públicas dos países desenvolvidos vêm se instrumentalizando para se aproximar e atender suas comunidades e seus públicos específicos por meio da implantação de ações planejadas e viabilizadas com recursos públicos.

As práticas sociais desencadeadas por coletivos nesses países datam da criação de suas associações de classe, tais como a American Library Association (ALA), nos EUA, em 1876, e a Library Association (LA), na Inglaterra, em 1877.

A obra "Libraries and democracy: the cornestones of liberty", editada pela ALA, apresenta-nos a história e o pensamento anglo-saxão das práticas biblioteconômicas voltadas para a sociedade. Nele, a biblioteca é vista como um espaço cultural, ativo e representativo para o exercício da cidadania e de defesa da democracia. $E$ as associações são importantes agentes na defesa desse pensamento. Um exemplo disso é o relato de Joneta Belfrage (2001) sobre a articulação feita pela Swedish Library Association, quando percebem que o governo sueco, ao lançar uma discussão aberta sobre os problemas e o potencial democrático para o século XXI naquele país, se esqueceu de incluir as bibliotecas públicas como espaço de diálogo. A Associação imediatamente montou um comitê com a tarefa de reverter essa situação e demonstrar ao governo a importância da biblioteca para um Estado democrático: um espaço de debate permanente e atemporal, espaço de aprendizagem, participação e acesso aos caminhos do conhecimento em busca do empoderamento de toda a população (BELFRAGE, 2001). Nesse momento, a Swedish Library Association percebeu que sua ação teria que ir além do diálogo com políticos e que precisava também preparar os bibliotecários para enfrentar situações semelhantes. Nesse sentido, foram abertos 
espaços de discussão interno com os próprios bibliotecários, além de seminários e debates com o governo e com a sociedade.

No que tange a movimentos de criação de bibliotecas comunitárias, o histórico apresentado por Crawford (2002) esclarece que foi a partir da ação estratégica da igreja que surgiu o movimento de bibliotecas comunitárias na Escócia no século XVII, sendo esse o responsável pela circulação de livros pelo país naquela época, tendo em vista que essas pequenas bibliotecas estavam muito mais próximas da população do que as bibliotecas das universidades. Segundo o autor, no século seguinte surgem dois novos movimentos de criação de bibliotecas comunitárias naquele país, um para a classe média e outro para a classe de trabalhadores. Esses movimentos alteram-se no seu formato ao longo do tempo em função do surgimento de novos tipos de bibliotecas até que, no século $X X$, são praticamente extintos. Porém, como já dito anteriormente, tiveram uma influência muito significativa na história da vida intelectual escocesa e suas práticas democráticas foram incorporadas e são identificadas até hoje na administração das bibliotecas públicas.

$\mathrm{Na}$ Europa em geral, os movimentos cooperativistas, que datam do século XIX, também registram a criação de bibliotecas comunitárias para atender as demandas das famílias cooperadas. No Brasil, por sua vez, identificamos que nas décadas de 1920 e 1930, os movimentos operários anarquistas preocupavam-se em organizar centros culturais e pequenas bibliotecas. Os movimentos revolucionários do período da ditadura e pós-ditadura também se esforçaram para criar suas bibliotecas e centros de documentação. Hoje vemos o Movimento dos Sem Terra (MST) unindo esforços no sentido de reunir intelectuais, técnicos e a comunidade para criar uma biblioteca que dê apoio pedagógico para a formação dos seus integrantes. O MST tem ainda em seus planos a meta de expandir a criação de bibliotecas comunitárias nos assentamentos espalhados por todo o território nacional.

Curiosamente, a primeira biblioteca pública brasileira, criada em Salvador em 1811, é fruto de uma iniciativa pessoal de um senhor de engenho, Pedro Gomes Ferrão Castelo Branco. Rubem Borba de Moraes (2006) em sua pesquisa sobre as bibliotecas no Brasil Colonial, aponta para o grande número de iniciativas particulares na Bahia, que não partiam do governo, e sim da elite letrada, que, consciente da miséria cultural do povo e da sua responsabilidade coletiva, toma para si a iniciativa pela instrução popular. O Plano de criação dessa primeira biblioteca 
previa a cooperação de todos os cidadãos que desejassem fazer parte dela. Dentro da idéia de participação esse exemplo caracteriza-se como uma atitude democratacristã, pois a biblioteca em questão foi idealizada para suprir uma carência social.

A mobilização de intelectuais nos anos 1930, a exemplo do grupo liderado por Mário de Andrade em São Paulo e por Cecília Meireles no Rio de Janeiro, sem dúvida foi um fator determinante na história da Biblioteconomia no Brasil. Esse movimento desencadeou um processo de envolvimento de bibliotecários na idealização de novos modelos biblioteconômicos, na formação de novos profissionais, suportado por uma idéia de criação de uma política pública de cultura que fosse nacional. A cultura naquela época teve um papel educativo e, assim, os projetos na área de Biblioteconomia seguiram o mesmo trajeto. Almeida Junior (1997), Emir Suaiden (1995), Gilda Verri (1996) e Patrícia Raffaini (2001) apresentam-nos um panorama bem amplo sobre o processo histórico desse momento.

Cabe destacar o relato sobre a história da criação de serviços de informação às comunidades, no mundo, no âmbito dos serviços bibliotecários apresentado por Emir Suaiden no seu livro: "Bibliotecas Públicas e informação à comunidade".

A partir da década de 1980, período de redemocratização do país, ampliaramse os debates acerca dos conceitos de participação, emancipação social, ética e cidadania, mas não na literatura biblioteconômica. É como se a biblioteca, seus profissionais e seus serviços não exercessem influência nas relações de poder, ou não sofressem mudança em função do estado de cultura em que a sociedade se encontra.

O único projeto que encontramos voltado para a mobilização da sociedade, com o intuito de criar bibliotecas comunitárias, liderado por entidade vinculada à área de Biblioteconomia, é o do Conselho Regional de Biblioteconomia de Tocantins, o qual está registrado no banco de ações do Programa Nacional do Livro e Leitura $(\mathrm{PNLL})^{5}$.

As associações de bibliotecários passaram por momentos áureos de organização e luta, respectivamente nas décadas de 1970 e 1980, mas foram se desestruturando e perdendo sua força e, assim, a possibilidade de atuar de forma coletiva no sentido de colaborar no desenvolvimento de novas práticas

\footnotetext{
${ }^{5}$ Endereço eletrônico: http://www.vivaleitura.com.br/calendario_detalhe.asp?id_projeto=279
} 
biblioteconômicas pautada em pensamentos e ações sociais que tivessem impacto no processo de desenvolvimento social.

A Federação Brasileira de Associações de Bibliotecários, Cientistas da Informação e Instituições (FEBAB) registra no seu sítio eletrônico apenas 17 associações filiadas, sendo uma em cada um dos seguintes estados: Amazonas, Ceará, Distrito Federal, Goiás, Maranhão, Mato Grosso do Sul, Minas Gerais, Pará, Paraíba, Paraná, Pernambuco, Piauí, Rio Grande do Norte, Rio Grande do Sul, Santa Catarina e Sergipe. E duas em São Paulo, sendo que uma delas é a Associação Paulista de Bibliotecários (APB), a mais antiga do país, fundada em 1938 sob a presidência de Rubens Borba de Moraes, que se encontra praticamente desativada.

Temos que reconhecer que foi a partir de 1975, que a FEBAB abriu espaço para divulgação e debate de pensamentos e experiências com foco na Biblioteconomia como prática social nos Congressos Brasileiros de Biblioteconomia e Documentação (CBBD). No entanto, não se tem notícia de nenhuma articulação, ou apoio da instituição no sentido de fomentar os trabalhos apresentados nesses congressos. A seguir destacamos os temas eleitos, que sugerem a preocupação da entidade com o assunto.

$\checkmark$ Responsabilidade social das bibliotecas no plano setorial da educação 80. CBBD de 1975.

$\checkmark$ Informação em uma sociedade democrática - 13o. CBBD de 1985.

$\checkmark$ Biblioteca e democratização da informação - 140. CBBD de 1987.

$\checkmark$ Informação para a cidadania e o profissional da informação no novo milênio - 19o. CBBD de 2000.

$\checkmark$ Livro, leitura e bibliotecas: exercício da cidadania - 210. CBBD de 2004.

$\checkmark$ Igualdade e diversidade no acesso à informação: da biblioteca tradicional à biblioteca digital - 220. CBBD de 2007.

A International Federation of Library Associations and Institutions (IFLA), por sua vez, no nível mundial, vem fomentando o debate e criando comitês permanentes para atuar no sentido de articular e ampliar as práticas sociais na área. Cabe destacar que a IFLA, desde sua criação em 1927, tem se dedicado não só a representar os interesses das bibliotecas e dos serviços de informação, mas também 
dos usuários da informação. Ou seja, a instituição sai do âmbito corporativista quando desloca seu olhar para o usuário da informação.

Retomando o fato identificado anteriormente sobre a ampliação de interesse dos alunos dos cursos de Biblioteconomia pelo tema, esclarecemos que na justificativa de seus trabalhos pudemos identificar 0 interesse desses jovens em atuar em projetos desse tipo e nos parece que o TCC passa a ser a primeira iniciativa nessa linha.

Alguns projetos de pesquisa se iniciam nas universidades sobre o tema. É o caso da pesquisa "Bibliotecas comunitárias em regiões de exclusão social na cidade de São Paulo", do curso de Biblioteconomia da Universidade Estadual Paulista (Unesp) de Marília, realizada no período de 2002 a 2003, que resultou no TCC da aluna Charlene Lemos. E também, do projeto de pesquisa "Bibliotecas como prática de responsabilidade social" que vem sendo realizado por esta pesquisadora na Universidade Federal do Estado do Rio de Janeiro (UNIRIO).

Amplia-se também o número de alunos estagiários e bibliotecários atuando em bibliotecas especializadas de ONGs responsáveis por uma significativa atuação em projetos sociais. Provavelmente em função da cultura dessas organizações, esses profissionais, passam a atuar e a produzir cientificamente na área de maneira a valorizar a prática social. Podemos citar o Instituto Pólis, a Ação Educativa e a Pastoral da Criança como exemplos de ONGs que contam com bibliotecários atuando na gestão de seus acervos e na criação de serviços de informação.

Numa tendência característica dos tempos da pós-modernidade, as práticas sociais estão sendo incorporadas pela sociedade civil como um fator de responsabilidade social, seguindo muitas vezes o modelo do mercado. Nesse contexto, encontramos inúmeros Institutos, Fundações e Organizações da Sociedade Civil de Interesse Público (OSCIP), envolvidas em projetos orientados para a comunidade que visam o envolvimento da sociedade em ações de criação de bibliotecas, projetos de leitura e formação de mediadores de leitura. Esse fato pode ser conferido em uma breve consulta ao Banco de Ações do Programa Nacional do Livro e da Leitura (PNLL).

Entre os inúmeros programas e projetos desse tipo podemos dar como exemplo, a título de ilustração, o Programa Biblioteca Viva e o Programa Mudando a História, da Fundação Abrinq, e o Programa Ler é Preciso, do Instituto Ecofuturo. São apenas alguns exemplos de praticas sociais que têm se desenvolvido a partir da 
articulação de vários agentes, individuais e coletivos, da sociedade civil, das empresas e do governo.

Tratando-se de responsabilidade social, não podemos deixar de lembrar o alerta feito por Boaventura de Souza Santos a partir de pesquisas realizadas no Brasil sobre a forma como esses projetos tratam a questão da participação. Para o autor, muitos desses projetos podem fazer parte de um processo de cooptação, porém, ainda assim, eles representam "uma inovação capaz de gerar modelos contra-hegemônicos de democracia" (SANTOS, 2005, p. 65).

Quando falamos em prática social na Biblioteconomia e Ciência da Informação, não podemos deixar de citar o movimento de acesso livre, que vem sendo liderado, no Brasil, pelo Instituto Brasileiro de Informação em Ciência e Tecnologia (IBICT), órgão vinculado ao Ministério da Ciência e Tecnologia, uma referência importante na história da área. Assim como, o Mapa da Inclusão Digital no Brasil (MID) que vem identificando os telecentros, infocentros, salas de informática, centros de inclusão digital, lan house e cibercafé. 


\section{A POLÍTICA CULTURAL E A BIBLIOTECA}

Muitos costumam relacionar as bibliotecas públicas à área de Educação. No entanto, elas estão inseridas institucionalmente na área de Cultura. Portanto, são as políticas culturais que, por meio de sua administração pública e do conjunto de leis e regulamentações, buscam caminhos para o fortalecimento dessas bibliotecas e o estabelecimento de ações de longo alcance, com caráter permanente. Referimo-nos aqui somente às bibliotecas públicas, pois até 2007 , quando se falava em políticas públicas para bibliotecas não se incluíam as bibliotecas comunitárias.

Para nós, a relação estabelecida entre a biblioteca pública e a Educação, se dá por três motivos: primeiro, pelo forte caráter educacional que essa biblioteca desempenha; segundo, pela carência de bibliotecas escolares no Brasil; e, terceiro, pelo fato da cultura ser a base de toda a sociedade e suas ações terem por princípio a transversalidade e a multiplicidade. Nesse sentido, pensar a cultura e políticas públicas culturais é reconhecer a complexidade que envolve vários elementos, esferas, níveis e atores, ou seja, como afirma Edgar Morin (2002, p. 38), confrontamo-nos "cada vez mais e de maneira cada vez mais inelutável com os desafios da complexidade."

Nos tempos de pós-modernidade, a estrutura organizacional do Estado, centralizada, rígida, hierarquizada e fragmentada, não colabora e muitas vezes, inviabiliza ações transversais que são características das ações culturais. O Estado precisa inverter essa lógica, de forma a descentralizar, flexibilizar e criar estruturas abertas e horizontais, que possibilitem a criação de políticas culturais no nível nacional e local, e principalmente, com a participação da sociedade.

Segundo Lia Calabre (2007, p. 1), "a institucionalização da política cultural é uma característica dos tempos atuais." No Brasil, segundo a autora, foi no governo de Getúlio Vargas (1930-1945) que foram implantadas o que se pode chamar de primeiras políticas culturais, naquele momento com o objetivo de institucionalizar o setor cultural.

No ano de 1937 foi criado o Instituto Nacional do Livro (INL), o que pode ser considerado uma das primeiras iniciativas organizadas de âmbito federal que tinha a expansão das bibliotecas públicas como uma das principais metas. Apesar disso, mais de 70 anos depois do estabelecimento dessa meta, e de outros projetos 
similares criados durante esse período, ainda encontramos, no território nacional, municípios que não possuem uma única biblioteca pública. Infelizmente, não sabemos exatamente quantas bibliotecas públicas temos no país e onde estas se localizam, que dirá bibliotecas comunitárias.

Cabe lembrar que o Brasil sempre teve uma grande dificuldade em coletar, organizar e sistematizar informações sobre suas ações, acervos e equipamentos culturais. Esse fato é evidenciado pela UNESCO (2006) em seu texto sobre as estratégias de atuação no Brasil. A partir da afirmação de que pouco se fez para avaliar o verdadeiro valor da cultura no país, o órgão sugere a criação de bancos de dados e de um sistema permanente de avaliação.

Ladislau Dowbor vai além, ao colocar a interoperabilidade dos bancos de dados como um eixo fundamental em sua proposta estratégica para a criação de redes de apoio ao desenvolvimento local. Segundo o autor (DOWBOR, 2006, p. 11):

a informação bem organizada e disponibilizada constitui um poderoso instrumento de auto-regulação na base da sociedade, pois todos os atores sociais, empresários, secretários municipais, organizações comunitárias etc., passam a tomar decisões mais bem informadas.

Nos últimos anos, algumas ações vêm sendo implementadas pelo Ministério da Cultura (Minc) para suprir o déficit da informação pública organizada na área de cultura. No âmbito geral, em 2004 foi firmado um convênio com o Instituto Brasileiro de Geografia e Estatística (IBGE) com o objetivo de criar o Sistema de Informação e Indicadores Culturais.

Especificamente no que se refere às informações sobre bibliotecas, o Sistema Nacional de Bibliotecas Públicas (SNBP) disponibiliza um cadastro ${ }^{6}$ das bibliotecas públicas conveniadas ao órgão. Paralelamente, no ano de 2003, o Minc deu início à constituição de um banco de experiências ${ }^{7}$ com vistas a mapear as ações em prol do livro e da leitura. Essas iniciativas são dignas de aplauso, mas, foram criadas de forma desarticulada e não prevêem a interoperabilidade entre os bancos de dados 0 que limita seu acesso.

Hoje, com as novas tecnologias, a biblioteca pública deveria ser o ponto de apoio local para a sociedade ter acesso à informação. No entanto, essas bibliotecas,

\footnotetext{
${ }^{6}$ Endereço eletrônico: http://catalogos.bn.br/scripts/odwp012k.dII?INDEXLIST=snbp_pr:snbp

${ }^{7}$ Endereço eletrônico: http://www.pnll.gov.br/
} 
ainda são vistas pelo poder público como um espaço unicamente físico, de organização de documentos no suporte papel e que, quando muito, têm condições de oferecer aos seus usuários atividades presenciais de incentivo à leitura na forma de ações culturais.

Conforme vimos nas discussões anteriores, a herança histórica brasileira de desigualdades favorece o processo de desmonte do Estado, do serviço público e das instituições ligadas a ele, tais como as bibliotecas públicas. Em sua maioria, as bibliotecas públicas brasileiras não possuem recursos suficientes para se manter, para atualizar seus acervos, investir em tecnologia e muito menos na formação e qualificação de suas equipes, prescindindo muitas vezes do próprio profissional formado. Em 1999, segundo dados da Fundação Biblioteca Nacional, as bibliotecas públicas, eram em sua maioria, dirigidas por leigos " $52 \%$ dos dirigentes possuem apenas o $2^{\circ}$. Grau e 13\% apenas o 1‥ Grau” (BIBLIOTECA NACIONAL, 2000, p. 23). Acreditamos que esse quadro não tenha se alterado substancialmente nos últimos anos.

O discurso político sempre defendeu e ressaltou a importância das bibliotecas públicas, mas na prática, pouco foi feito para apoiar efetivamente estas instituições. No que se refere ao acesso à informação, Prado (2004) considera que as ações decorrentes desses discursos podem ser muito mais caracterizadas como estratégias de marketing do que apoio ou articulações no sentido de fortalecer essas instituições. Em seu trabalho sobre a biblioteca comunitária do semi-árido brasileiro, o autor afirma que "uma das tradições do Estado brasileiro é estar constantemente formulando políticas salvacionistas para o país."

Foi a partir de 2003, com Gilberto Gil na liderança do Ministério da Cultura, que o Estado passou a dialogar com seus interlocutores e assim identificar e valorizar manifestações até então ignoradas. Ampliaram-se os debates e as possibilidades de participação da sociedade na construção de políticas públicas para a área, redefinindo assim os rumos em relação à gestão pública de cultura. Nesse contexto, em 2005 foi criado o Sistema Federal de Cultura, com o objetivo de caminhar no sentido de integrar os órgãos, programas e ações do governo federal. Com esse caráter é lançado, em 2006, o Programa Nacional do Livro e da Leitura (PNLL), um programa que surge com o objetivo de reunir e organizar as ações relacionadas ao livro, à leitura, à literatura e à biblioteca que vinham sendo implementadas no país de maneira dispersa e desarticulada. 
Dando continuidade ao processo de articulação e estabelecimento de políticas públicas o governo lançou, em outubro de 2007, por meio do Decreto No. 6.226, o Programa Mais Cultura, que, com conceitos inovadores e de maneira aberta à participação da sociedade, se apresenta como uma ação que vem preencher o vazio da política cultural de Estado que parecia perpetuada no país. Com a previsão de investir $R \$ 4,7$ bilhões na área até 2010 propõe-se a agir de forma ampla, contundente e transversal no mapa das prioridades que o momento atual impõe para a sociedade no que se refere à Cultura.

Historicamente, o Ministério da Cultura se apresenta como uma instituição pobre, com parcos recursos e uma diminuta estrutura organizacional, incompatível com as demandas atuais e de um país permeado pela diversidade como é o Brasil. Hoje, o Ministério conta com apenas $0,6 \%$ do Orçamento da União, sendo que a ONU recomenda 1\% (MEDEIROS, 2008).

Essa condição justificou a criação de leis de renuncia fiscal, transferindo para a iniciativa privada o poder de definir os investimentos na área. Nesse cenário, o Programa Mais Cultura traz a esperança de, finalmente, caminharmos no sentido de restabelecer o papel do Estado como responsável por criar e articular as diretrizes que garantam o fomento e o apoio contínuo para as ações culturais no nível nacional e local.

A partir desse contexto, podemos iniciar uma discussão específica sobre como estão sendo formuladas e implementadas as políticas públicas nos dias de hoje, especificamente para bibliotecas, no âmbito da Federação e dos municípios.

\subsection{POLÍTICAS PÚBLICAS NACIONAIS PARA BIBLIOTECAS}

Desde a criação do INL, em 1937, os governos se esforçavam na criação de bibliotecas públicas, criadas como ações governamentais sem a participação da sociedade. É nesse último governo, a partir de 2003, que percebemos algumas mudanças no sentido de ampliar o diálogo e a participação da sociedade.

Apesar de nem sempre terem obtido sucesso e, em alguns casos, não estarem articuladas de maneira a serem potencializadas, algumas ações do Estado anteriores a 2003 merecem atenção 
Em 1992, no âmbito Federal, vinculado ao Ministério da Cultura, foi criado o Sistema Nacional de Bibliotecas Públicas (SNBP) com o principal objetivo de fortalecimento das bibliotecas públicas por meio da "implantação de um processo sistêmico baseado em ações voltadas para a interação e integração dessas bibliotecas em âmbito nacional" (BIBLIOTECA NACIONAL, 2006). Para tanto, criouse em cada estado brasileiro um Sistema Estadual de Bibliotecas Públicas, o qual, por sua vez, tem por meta articular as ações das diversas Bibliotecas Públicas Municipais. Atualmente, é de responsabilidade do SNBP o desenvolvimento das seguintes ações: programa Livro Aberto, que propõe implantar bibliotecas em municípios que não as possuem e a revitalizar as já existentes; cadastro de bibliotecas públicas; capacitação e seminários; e assessoria técnica para as bibliotecas que fazem parte do sistema.

A nosso ver, a concepção do SNBP foi inovadora, no sentido de propor um sistema que pudesse agir de forma ramificada nesse país de dimensões continentais. Por meio da organização sistemática de programas de apoio poderia, também incluir em suas metas a criação de uma rede de sustentação para as inúmeras iniciativas locais de bibliotecas comunitárias. Porém, infelizmente, desde sua criação o SNBP nunca teve abertura suficiente para o estabelecimento de articulações locais. Sua subordinação à Fundação Biblioteca Nacional (FBN) amarrou sua estrutura, eliminando a possibilidade de agir de maneira autônoma e, conseqüentemente, minando sua capacidade e força para atuar efetivamente e de maneira contínua na dinamização e no fortalecimento desses espaços.

Esse fato nos faz lembrar o que diz Ladislau Dowbor (1995, p. 4): "o Estado tradicional faz figura de dinossauro, amplamente ultrapassado por uma dinâmica que exige respostas rápidas e flexíveis a situações diversificadas e complexas."

Ainda em 1992, o governo federal lança o Programa Nacional de Incentivo à Leitura (PROLER), também vinculado à FBN. O PROLER, por meio de seus comitês regionais, desenvolve ações em parceria com as secretaria estaduais e municipais de cultura e educação pelo país. Em sua sede, no Rio de Janeiro, denominada como Casa da Leitura, são oferecidos cursos de formação, palestra, entre outras atividades de incentivo à leitura para professores, bibliotecários e agentes de leitura da rede pública.

Em 1993 surge o programa Uma Biblioteca em Cada Município que tinha o objetivo de implantar bibliotecas pelo país. O compromisso era de distribuir estantes, 
livros e oferecer capacitação para o gerenciamento dessas bibliotecas. Durante o período de 1993 até 2003, acompanhamos esses programas se sobrepondo e agindo pontualmente e fragmentadamente. Não foram oficializados os resultados nem mesmo os impactos gerados durante esse período para que pudessem ser analisados de forma consistente.

O Ministério da Educação, por sua vez, no que diz respeito ao acesso ao livro e estimulo à leitura para alunos do ensino fundamental e médio, vem ao longo dos anos traçando suas políticas com foco na aquisição, distribuição de livros e fomento às bibliotecas escolares e salas de leitura. É o caso do Programa Nacional do Livro Didático (PNLD), do Programa Nacional Bibliotecas da Escola (PNBE), da Política de Formação de Leitores e do Programa Nacional Biblioteca da Escola para o Ensino Médio (PNBEM) lançado recentemente em 2007.

Luiz Percival Leme Britto, presidente da Associação de Leitura do Brasil (ALB) e organizador de um dos mais importantes eventos da área, o Congresso de Leitura do Brasil (COLE), ao se referir aos programas de governo de promoção da leitura, tais como o PNBE e o PROLER esclarece que, apesar de nos últimos anos esses programas terem colaborado para que muitas obras de literatura passassem a circular por lugares que antes quase não tinham acesso a qualquer tipo de leitura, eles não passaram de ações isoladas. Segundo o educador, "além da insuficiência de recurso, falta uma política de Estado sistemática e orgânica que viabilize ações mais integradas." (AÇÃO EDUCATIVA, 2003, p. 71).

No que tange ao acesso à informação no mundo digital, o Programa Sociedade da Informação (SOCINFO), lançado em 1996 pelo Ministério da Ciência e Tecnologia, considerou, em suas metas, as bibliotecas públicas como pontos focais naturais para difusão, captação e processamento de conteúdos de interesse público. Dentre as inúmeras ações previstas estava a conexão de todas as bibliotecas públicas do país (TAKAHASI, 2000).

Tendo em vista as precárias condições de comunicação do país em 2000, foi criado o Fundo de Universalização de Serviços de Telecomunicações (FUST), pelo Ministério das Comunicações, com o objetivo de gerar recursos para cobrir os custos da infra-estrutura necessária para a universalização dos serviços de telecomunicações, essenciais para que se pudessem cumprir metas como a de 
conexão das bibliotecas públicas ${ }^{8}$. No entanto, até hoje nenhum recurso foi destinado a esse fim.

Segundo Prado (2004, p. 17),

a proposta da Socinfo era utilizar os recursos dos FUST correspondente a $1 \%$ do valor dos serviços da telefonia no Brasil para instalar em todo o país aproximadamente 12 mil telecentros em pequenas comunidades. Esses telecentros seriam conectados à Internet e acoplados a mini-bibliotecas com kits de mais ou menos 400 livros, cujo objetivo era facilitar a divulgação e a democratização da informação, da comunicação, da educação e da cultura.

Ainda segundo o mesmo autor, se isso realmente tivesse acontecido, teríamos conseguido reduzir drasticamente o analfabetismo digital no Brasil.

O Ministério da Reforma Agrária, por sua vez, por meio da Secretaria do Desenvolvimento Agrário, lançou em 2003 o projeto Arca das Letras com o objetivo de criar bibliotecas rurais e formar agentes de leitura locais para atuar nesses espaços. O projeto prevê o envio de uma caixa-estante, fabricada por sentenciados de penitenciárias estaduais, com uma coleção de 230 livros. Em 2006, criou complementarmente o projeto Bibliotecas Famílias Agrícolas, focando na distribuição de livros para as Escolas Famílias Agrícolas e Casas Familiares Rurais.

Segundo os coordenadores do projeto Arca das Letras, até julho de 2008, foram criadas mais de 6.000 bibliotecas comunitárias em zonas rurais do país, especificamente em assentamentos da reforma agrária, em comunidades de agricultura familiar, comunidades de remanescentes de quilombolas, indígenas, ribeirinhas e em colônias de pescadores (informação verbal) ${ }^{9}$. O projeto inicia o contato com a comunidade por meio das organizações comunitárias locais, tais como sindicatos e movimentos sociais e prevê, em sua metodologia de implantação, a participação das comunidades na definição do espaço a ser ocupado pela biblioteca, na formação do acervo, na definição do funcionamento e na sua gestão.

A coordenação do projeto é de responsabilidade de uma bibliotecária e, dentre as ações governamentais que estão sendo desenvolvidas na área, a metodologia proposta é um diferencial. Tendo em vista a características específicas dessas bibliotecas e o grande número de unidades que conseguiram implementar, a

\footnotetext{
${ }^{8}$ Artigo 5․ Parágrafo IV, VI, VII, VII da Lei no. 9.998 de 17 de agosto de 2000.

${ }^{9}$ Informação fornecida por Cleide Soares, bibliotecária coordenadora do Programa Arca das Letras, durante $2^{\circ}$. Fórum do Plano Nacional do Livro e Leitura, em agosto de 2008.
} 
coordenação planeja a criação de um Sistema Nacional de Bibliotecas Rurais para acompanhar as experiências e criar mecanismos de troca de informação entre elas.

Com esses exemplos estamos tentando demonstrar que as ações governamentais voltadas para a área de bibliotecas não se restringiram apenas ao Minc, outros órgãos e ministérios incluíram em seus programas ações, que de alguma forma potencializavam esses espaços, o que consideramos de imenso valor. No entanto, o problema, a nosso ver, é que o Sistema Nacional de Bibliotecas Públicas não assume sua função de articulador, o que, conforme já vimos, pode ocorrer pelo fato de estar dentro de uma estrutura muito complexa, como é o caso da Fundação Biblioteca Nacional.

O Programa Fome de Livro, instituído no início de 2005, surge como uma estratégia para articular o conjunto de ações realizadas pelo Estado, pelas empresas e pela sociedade civil organizada. Paralelamente, com o objetivo de iniciar um grande movimento nacional e em sintonia com o Plan Ibero-americano de Lectura, o governo federal estabeleceu o ano de 2005 como o ano do livro e da leitura e instituiu a marca VIVALEITURA. Em decorrência dessa ação surgiu, capitaneada pelo Ministério da Cultura, o Programa Nacional do Livro e da Leitura (PNLL) com a intenção de se constituir numa política de Estado para a área. A partir desse momento, inicia-se um processo de articulação dos inúmeros projetos, programas, ações e atividades em geral ligadas ao livro, à leitura a literatura e a biblioteca.

Nos objetivos do PNLL podemos constatar a disposição do Estado em reorganizar a situação atual, no sentido de articular ações até então dispersas e fragmentadas.

[...] criar condições e apontar diretrizes para a execução de políticas, programas, projetos e ações continuadas por parte de diferentes esferas de governo e também por parte das múltiplas organizações da sociedade civil [...] (PLANO NACIONAL DO LIVRO E DA LEITURA, 2006).

Sem dúvida, não podemos deixar de reconhecer o forte cunho participativo pelo qual o processo foi permeado: foram realizadas inúmeras reuniões regionais e nacionais para discussão e formulação dessa nova política nacional para o livro e a leitura, além das constituições dos representantes e conselhos regionais. Nunca no país tinha ocorrido um processo semelhante.

A proposta foi de reunir governo (federal, estadual e municipal), universidades, professores, bibliotecários, escritores, ONGs e empresas privadas 
que tivessem envolvimento com o assunto. Na área biblioteconômica, temos a participação da Federação de Associações de Bibliotecários (FEBAB), dos Conselhos de Biblioteconomia, das Universidades e representantes de bibliotecas dos estados e do município; porém, o bibliotecário que está na biblioteca, ou mesmo os alunos que estão se formando para desenvolver atividades voltadas ao acesso à informação, à leitura e ao livro, pouco se envolveram no processo. No entanto, é curioso constatar como é ampla e significativa a participação de editores e livreiros.

Abrimos aqui um parêntese para evidenciar o fato de que para nós é significativo que a palavra "livro" seja sempre colocada a frente da palavra "leitura" na concepção desses programas e, mais, da palavra "biblioteca" ser excluída. Entendemos que a valorização do livro como objeto está relacionada à valorização do mercado editorial que, de forma organizada, exerce uma forte pressão sobre o Estado: um exemplo da forma inapropriada de participação que Marilena Chaui designa como socialdemocrata e liberal. Como, até o momento, as políticas públicas de Estado sempre pararam na fase da compra de grandes quantidades de livros para distribuição entre bibliotecas, sejam elas públicas ou escolares, acreditamos que esse grupo tenha, ao longo de décadas de experiência, aperfeiçoado sua prática de participação.

Para Marisa Lajolo, a indústria editorial precisa ter mais responsabilidade social e sugere que o governo exija uma contrapartida na compra de grandes quantidades de livros de uma editora. Por exemplo, "o governo compra uma certa quantidade de livros, desde que as editoras desenvolvam uma forma melhor de distribuição". Ainda segundo a autora, "a grande quantidade comprada pelo governo barateia muito o livro, cada unidade custa cerca de 34 centavos; ou seja, esses livros poderiam ser vendidos a poucos reais em banca de jornal, em açougue, em feira livre." (AÇÃO EDUCATIVA, 2003, p. 55).

No dia 4 de outubro de 2007, por meio do Decreto Federal No. 6.2260 Presidente da República instituiu o Programa Mais Cultura, com o objetivo de:

I- ampliar o acesso aos bens e serviços culturais e meios necessários para a expressão simbólica, promovendo a auto-estima, o sentimento de pertencimento, a cidadania, o protagonismo social e a diversidade cultural;

II - qualificar o ambiente social das cidades e do meio rural, ampliando a oferta de equipamentos e dos meios de acesso à produção e à expressão cultural; e 
III-gerar oportunidades de trabalho, emprego e renda para trabalhadores, micro, pequenas e médias empresas e empreendimentos da economia solidária do mercado cultural brasileiro.

(BRASIL, 2007a, p. 1)

Pela primeira vez, na história desse país, um programa de governo na área de cultura inclui em suas ações e diretrizes as bibliotecas comunitárias (BRASIL, 2007b, p. 15).

O avanço se dá também na criação de uma Câmara Técnica com a tarefa de "articular ações intersetoriais para o desenvolvimento do Programa" com a participação de vários Ministérios, Secretarias, da Casa Civil, assim como de representantes de outras instituições públicas, da sociedade civil e de especialistas. O monitoramento do programa, por sua vez, ficou a cargo do Conselho Nacional de Política Cultural (CNPC) (BRASIL, 2007a).

O Programa prevê três linhas de ações, sendo que a rede de bibliotecas públicas faz parte da primeira linha de ação, "Cultura e cidadania", que tem por diretriz "garantir o acesso dos brasileiros aos bens e serviços culturais." As bibliotecas comunitárias fazem parte da segunda linha de ação, "Cidade Cultural", que tem por diretriz "qualificar o ambiente social das cidades, ampliando a oferta de equipamentos e os meios de acesso à produção e à expressão cultural." A terceira linha do Programa refere-se a "Cultura e renda" e tem por diretriz "gerar oportunidades de trabalho, emprego e renda para trabalhadores, micro, pequenas e médias empresas." (BRASIL, 2007b).

Segundo a apresentação do Programa Mais Cultura, com a ampliação do conceito dos Pontos de Cultura, serão criados os Pontos de Leitura que incorporarão as bibliotecas comunitárias. O Ponto de Cultura é uma ação do Programa Cultura Viva e articula todas as demais ações desse Programa (BRASIL, [2007?]). Ele se realiza por meio do estabelecimento de convênio entre o Minc e lideranças locais responsáveis por iniciativas culturais em comunidades espalhadas por todo o país. O Ponto de Cultura passa a ser o pólo de articulação da cultura local, organizado de maneira a impulsionar as ações que já existem nas comunidades. Segundo o Ministério, atualmente, existem mais de 650 Pontos espalhados pelo país e o Programa Mais Cultura prevê a criação de mecanismos de articulação entre os diversos Pontos, com o objetivo de criar as Redes de Pontos de Cultura e os Pontões de Cultura. 
O Programa Mais Cultura conta com um orçamento de 4,7 milhões, sendo 2,2 bilhões do orçamento da União e 2,5 de parcerias e patrocínios. Com esse orçamento o Minc prevê a construção ou reforma de 100 bibliotecas comunitárias em favelas e periferia. No documento de apresentação do programa estas iniciativas são identificadas de diferentes formas, tais como "espaços comunitários e culturais de multiuso", "bibliotecas espaços multiuso", "pontos de leitura", "bibliotecas públicas" ou "bibliotecas comunitárias". Até o momento parece-nos que os investimentos serão restritos à aquisição de acervo e infra-estrutura.

\subsection{POLÍTICAS PÚBLICAS LOCAIS PARA BIBLIOTECAS}

Quando pensamos na esfera local estamos nos referindo às políticas públicas criadas para bibliotecas pelos governos municipais e estaduais. Cabe esclarecer que a iniciativa de âmbito municipal, normalmente, tem menor visibilidade e, portanto, são mais difíceis de serem identificadas.

Infelizmente, quando chegamos mais próximos da população percebemos que os grandes projetos idealizados na esfera federal, na maioria das vezes, não chegam até ela. A maioria dos municípios, tradicionalmente, se comporta como cliente das políticas idealizadas no nível central e, o Ministério da Cultura, por sua vez, por meio de seus projetos de doação de acervos e equipamentos para bibliotecas, estimulou durante anos essa forma de relação. De maneira geral, o Minc sempre exerceu pouca influência sobre os estados e municípios brasileiros, diferentemente do Ministério da Educação. Sem consciência do potencial que têm esses espaços, os governos locais se contentam em receber kits padronizados de bibliotecas, sem nenhuma identificação com as necessidades locais, o que leva à criação de espaços sem atrativos e sem condições de atendimento adequado.

A partir de 2005, a forte divulgação feita pelo VIVALEITURA e o banco de experiências do PNLL, aliados ao momento atual em que a internet colabora para ampliar o acesso à informação, foram importantes no sentido de dar visibilidade para ações e experiências desenvolvidas no nível municipal e estimular a aproximação entre as esferas. Além disso, outro forte componente articulador foi a construção do Programa Nacional do Livro e da Leitura, com a participação, na Câmara Setorial do 
Livro e da Leitura (CSLL), de representantes de entidades de classe ou de bibliotecas públicas dos diversos estados e regiões.

De modo geral, a maioria dos municípios do país não possui políticas publicas especificas para a área de bibliotecas. A biblioteca pública é um organismo que sempre ficou vulnerável aos mandos e desmandos de seus governantes locais. São as grandes cidades que tradicionalmente se destacam nessa área, em sua maioria na região Sul e Sudeste. A seguir comentaremos algumas políticas públicas de bibliotecas desencadeadas por governos estaduais ou municipais a título de ilustração.

O governo do Estado de São Paulo, no ano de 2003, criou o "Programa São Paulo: Um Estado de Leitores" 10 que teve como principal objetivo zerar o número de municípios sem bibliotecas públicas. A ação foi articulada entre a Secretaria Estadual de Cultura, as prefeituras e a iniciativa privada. Além dessa grande meta, o Programa estimulou o desenvolvimento de outras ações, como por exemplo a realização do evento "Corredor Literário na Paulista", que se baseia no modelo de feiras de livro ao ar livre e prevê, também, a premiação "Prefeito Amigo da Leitura" e o "Selo Iniciativa Amiga da Leitura".

A Fundação Prof. Dr. Manoel Pedro Pimentel (FUNAP) ${ }^{11}$ vinculada à Secretaria de Estado da Administração Penitenciária de São Paulo incluiu em sua política cultural a criação de bibliotecas para a população prisional. Nesse caso, as bibliotecas são administradas pelos próprios detentos e são constituídas a partir de doação de livros.

$\mathrm{Na}$ cidade de São Paulo, nas últimas duas gestões de governo, foi criado o Sistema Municipal de Bibliotecas Públicas, que unificou os Departamentos de Bibliotecas Públicas e o de Bibliotecas Infanto-Juvenis, possibilitando maior sintonia entre as bibliotecas públicas de bairro, além da racionalização de recursos e serviços. Foram também criadas as bibliotecas dos Centros Educacionais Unificados (CEUs) as quais foram concebidas para atender tanto o público escolar como a comunidade local, ou seja, agem como biblioteca escolar e pública paralelamente. Outra intervenção importante nesse município foi o redirecionamento das ações de algumas bibliotecas de bairro, como é o caso daquelas que passaram a atuar como

\footnotetext{
10 Endereço eletrônico:

www.cultura.sp.gov.br/portal/site/SEC/menuitem.6eb44e481fba6c0ff828f049c19714a0/?vgnextoid=9a812993f4 4c8010VgnVCM1000001c01a8c0RCRD

${ }^{11}$ Endereço eletrônico: www.funap.sp.gov.br/news_107.html
} 
bibliotecas temáticas. Além disso, a Secretaria Municipal de Cultura criou, em 2006, três Pontos de Leitura, em espaços públicos, na região de Cidade Tiradentes, uma das áreas com menor ${ }^{12}$ Índice de Desenvolvimento Humano (IDH) da cidade.

Desde 2004, a cidade de São Paulo conta também com o Programa para a Valorização de Iniciativas Culturais (VAI), da Secretaria Municipal de Cultura que apóia, por meio da distribuição de recursos financeiros, projetos culturais liderados por jovens de baixa rende de regiões da cidade desprovidas de recursos e equipamentos culturais. O programa age como um mecanismo de financiamento para esses jovens que por meio de projetos concorrem a partir de editais lançados anualmente. Em 2007, dos 777 projetos inscritos foram selecionados 102, sendo que 3 projetos de bibliotecas comunitárias.

No interior do Estado de São Paulo, a cidade de Ribeirão Preto criou, em 2001, o "Programa Ribeirão das Letras" a partir da articulação com o governo federal e com a sociedade civil organizada, que resultou na constituição de uma rede de 80 bibliotecas públicas. As parcerias foram estabelecidas com escolas, associações de moradores, sindicatos e outros órgãos municipais. Além da criação de bibliotecas o programa inclui também atividades de incentivo à leitura, como o "Projeto Contadores de História" e a "Feira Nacional do Livro de Ribeirão Preto". Nesse caso, vemos um trabalho de articulação entre o município, a federação e a sociedade civil organizada que deram resultados concretos. Seria interessante a divulgação e o acesso público aos dados de avaliação e impacto dessa política para que pudéssemos considerá-la valida e quiçá uma referência para outros municípios.

Em 1996 foi implementado o projeto Faróis da Leitura na cidade de Curitiba, no Estado do Paraná, que se configuram como pequenas bibliotecas espalhadas pela cidade, vinculadas a Secretaria de Educação do município. Esse é um exemplo de política pública local definida a partir da necessidade de ampliar o acesso a informação e a leitura aos cidadãos daquele município.

É interessante perceber, que alguns governos locais vêem como um diferencial em sua gestão a construção de um prédio para abrigar a biblioteca pública. Em muitos desses casos, a inauguração é usada como fins eleitoreiros e a biblioteca como espaço de ação fica relegada, tendo os governos subseqüentes de lidar com o déficit deixado. É o que aconteceu, por exemplo, no município de Duque

${ }^{12} \mathrm{O}$ IDH de Cidade Tiradentes é de 0,446 enquanto que o de Pinheiros é 0,833. 
de Caxias, cidade da baixada fluminense, com a construção de uma grande biblioteca pública no centro da cidade, com a marca do arquiteto Oscar Niemayer, porém sem nenhuma relação com a identidade local.

Na mesma linha está a Secretaria de Estado de Cultura do governo do Distrito Federal quando lançou em 2002 o Projeto Conjunto Cultural da República, que previa a criação da nova Biblioteca Nacional Leonel de Moura Brizola, idealizada, sem nenhuma articulação com a Fundação Biblioteca Nacional com sede na cidade do Rio de Janeiro (DISTRITO FEDERAL, [2006?]). O prédio, inaugurado em 31 de março de 2006, permanece até a presente data fechado.

Mesmo sem os recursos do FUST, a necessidade de ampliar o acesso à informação e a preocupação com a alfabetização digital levou os governos, estaduais e municipais, assim como inúmeras organizações da sociedade civil, a desencadearem, nos últimos anos, um processo de criação de telecentros, infocentros, e outros centros com nomes semelhantes, com a função de dar acesso à informação para a população. Por incrível que pareça, as bibliotecas públicas municipais, que tem por princípio esta missão, foram praticamente esquecidas. Aos poucos, depois de muita luta por parte de seus responsáveis, algumas delas abrem espaços com as características de telecentros dentro de suas instalações. São os casos das Bibliotecas Públicas da Cidade de São Paulo, da Biblioteca Publica do Estado do Rio de Janeiro e da Biblioteca Pública do Paraná.

Cabe destacar algumas cidades que conseguiram, por meio de investimento em tecnologias e gestão da informação, criar mecanismos que, por um lado melhoram as condições de trabalho e as possibilidades de atuação da biblioteca pública e, por outro, colaboram para ampliar as formas de participação do cidadão. Um exemplo é a cidade de Américo Brasiliense ${ }^{13}$, que implantou o "Cartão do Cidadão" oferecendo à população a possibilidade de acesso à informação e ao livro como um serviço público, ou seja, por meio desse cartão ele pode tanto ir ao posto de saúde para um atendimento individual, como a uma biblioteca pública para fazer um empréstimo de um livro.

A cidade de Piraí, no Estado do Rio de Janeiro, tem se destacado por ter criado um projeto de desenvolvimento local que prevê o acesso a internet para todos os cidadãos. No entanto, no que se referem à biblioteca, não houve grande avanço.

${ }^{13}$ Endereço eletrônico: www.americobrasiliense.sp.gov.br/index2.htm 
Apesar da biblioteca pública ser muito bem localizada e do governo local ter se empenhado em criar mais três bibliotecas de bairro, chamadas de "Bibliotecas Comunitárias Celeiro das Letras", as mesmas não passam de lugares sombrios e sem atrativo algum para o estímulo a leitura e ao acesso à informação.

Como sabemos o acesso à internet é fundamental e determinante para o crescimento e melhoria da qualidade de vida de qualquer lugar e de qualquer cidadão. Porém, nesse caso, as bibliotecas ficaram aquém das possibilidades criadas na região, parece-nos que o avanço tecnológico que permeia a cidade não chegou até esta instituição.

Cabe esclarecer que apesar das bibliotecas de bairro terem em seu nome o termo qualificador "comunitárias" são bibliotecas públicas, criadas e mantidas pelo município local em parceria com o governo do Estado do Rio de Janeiro, o Banco do Brasil e a Universidade do Estado do Rio de Janeiro (UERJ).

Como podemos perceber, existem políticas públicas que são significativas no nível local, como em Curitiba, Ribeirão Preto e Américo Brasiliense, porém, ainda acreditamos que estamos caminhando a passos lentos, de maneira dispersiva e fragmentada no sentido de criar políticas para ampliar e fortalecer os espaços de acesso à informação e à leitura. Afinal, a maioria dos municípios não possuem uma política para a área de bibliotecas, ou da leitura e acesso à informação e, em alguns casos, é evidente o caráter impositivo e populista das propostas, a exemplo de Duque de Caxias, no Estado do Rio de Janeiro, e até mesmo do Distrito Federal.

Apesar de algumas das políticas acima citadas serem bem divulgadas, nenhuma delas conta efetivamente com a participação popular. Além disso, são pouquíssimas as associações de amigos de biblioteca que existem e são ativas. Esses são canais de participação que, de maneira organizada, poderiam atuar no sentido de ampliar, valorizar e potencializar a biblioteca pública.

No que se refere a políticas específicas de apoio às bibliotecas comunitárias o que identificamos foi ações advindas de bibliotecas públicas no sentido de fortalecer ou mesmo criar mecanismos para o estabelecimento de relações entre esses organismos e as bibliotecas comunitárias que surgem na região. É o caso do município de Guarulhos, Estado de São Paulo, onde a direção da Biblioteca Pública Central "Monteiro Lobato" criou um programa de capacitação para pessoas que atuam em bibliotecas comunitárias. Mensalmente são oferecidos cursos que tratam da formação, organização e preservação de acervos para esse tipo de biblioteca. 
Esta iniciativa faz parte da política criada pelo Sistema de Bibliotecas da cidade de Guarulhos, apoiada pela Secretaria Municipal de Cultura.

Outra ação semelhante acontece na cidade de Diadema, também localizada no Estado de São Paulo, por meio do Projeto Ação Compartilhada, que tem por objetivo a formação de multiplicadores comunitários voluntários. Nesse caso, a ação faz parte do programa de governo da Prefeitura, está dentro de uma proposta de apoio a iniciativas locais e sua implementação fica sob a responsabilidade da Secretaria Municipal de Educação. 


\section{UM OLHAR PARA A REALIDADE DAS BIBLIOTECAS COMUNITÁRIAS}

Todos nós estamos sentados na lama, mas alguns sabem ver as estrelas.

Oscar Wilde

Antes de iniciarmos a apresentação dos resultados e análises decorrentes desta pesquisa, consideramos importante esclarecer que, tendo em vista a grande quantidade de experiências identificadas durante o processo, totalizando 350 iniciativas, foi necessário criar um cadastro para organizar e controlar os dados coletados.

O critério básico para a inclusão de experiências nesse cadastro foi o nome da biblioteca que deveria conter o termo "comunitária". Porém, foram cadastradas também aquelas que são assim consideradas por seus idealizadores, mesmo não tendo o termo "comunitária" vinculado ao seu nome. É o caso, por exemplo, da Biblioteca Êxodos, na favela Sabin, no bairro do Capão Redondo, zona sul da cidade de São Paulo. Precisávamos, em primeira instância, reunir os dados de localização e contato para depois analisar se a experiência estava de acordo com o referencial teórico proposto.

Casos como o da Biblioteca Comunitária da Universidade Federal de São Carlos, ou da rede de bibliotecas públicas de São José dos Campos, que aplica o termo comunitária no nome de cada uma de suas unidades, não foram considerados no cadastramento, tendo em vista a vinculação direta com uma instituição universitária, ou órgão governamental. Estas iniciativas não se enquadram no conceito proposto neste trabalho.

Há casos em que, por trás do discurso de acesso à informação, à leitura e ao livro, existem fortes interesses políticos por parte do proponente. São projetos pessoais, em que o idealizador cria o espaço unicamente para divulgar seu nome na comunidade. Um exemplo é a Biblioteca Comunitária Graça Aranha, localizada no município de Santa Inês, no Estado do Maranhão (informação verbal) ${ }^{14}$. Experiências com estas características foram identificadas no projeto "Bibliotecas comunitárias do semi-árido brasileiro" e, pelo fato da sua concepção não se adequar aos conceitos propostos nesta pesquisa, foram também descartadas.

\footnotetext{
${ }^{14}$ Informação fornecida pelo Prof. Geraldo Prado, a partir da pesquisa coordenada por ele sobre o assunto, em abril de 2008.
} 
Cabe esclarecer, que nem sempre é possível identificar casos como os citados acima a partir das primeiras informações obtidas.

Durante todo o processo de levantamento de dados foram identificados, também, muitos projetos de incentivo à leitura, que desenvolvem atividades de mediação de leitura, mas que não se propõem a criar uma biblioteca comunitária. É o caso de projetos de caixas estantes, bibliotecas itinerantes como, por exemplo, o caminhão-biblioteca do Programa de Leitura Petrobrás, biblioteca flutuante como a Projeto Barca de Livros de Florianópolis, em Santa Catarina, ou ainda, o Jegue-livro na comunidade de Auzilândia, Maranhão. Todos esses projetos estimulam de maneira criativa o acesso ao livro e à leitura, mas, por serem itinerantes, não estabelecem um espaço fixo na comunidade e, por isso, não foram aqui considerados.

Alguns desses projetos, que têm como foco principal o estímulo à leitura, incluem em suas propostas a doação de pequenos acervos para uma determinada comunidade, além da formação de mediadores de leitura. Esse fato acaba desencadeando a criação de bibliotecas, como é o caso do Programa Expedição Vaga Lume, que atua na região da Amazônia Legal desde 2001 e que veremos com mais detalhes ao discutir o surgimento de bibliotecas a partir do estímulo de agentes coletivos externos à comunidade.

Outra observação importante é que a cada dia identificamos novas experiências, pois ao longo da pesquisa criamos uma rede de informações sobre o tema, envolvendo pessoas, grupos de jovens, entidades privadas e organizações não governamentais. No entanto, foi necessário fazer um corte no levantamento para que pudéssemos iniciar a análise proposta inicialmente.

Após este esclarecimento, podemos partir para a apresentação dos resultados, os quais são acompanhados de uma análise que procura integrar os dados, relatos e argumentos construídos a partir da relação entre o quadro conceitual e o objeto da pesquisa.

Optamos por organizar esta seção de maneira a responder às questões levantadas no início do trabalho, consideradas por nós o ponto de partida para uma reflexão aprofundada sobre o tema. Para tanto, iniciamos com a análise do conjunto das 350 experiências cadastradas, passando para a análise das 29 experiências que compõem o universo desta pesquisa. 


\subsection{ANÁLISE DO CONJUNTO DE EXPERIÊNCIAS IDENTIFICADAS}

Do total de 350 experiências identificadas, a maior parte, $41,71 \%$, encontra-se na região Sudeste do país, seguida da região Norte com 30,57\%, Nordeste com $23,14 \%$, Centro-Oeste com $2,57 \%$ e Sul com $2 \%$. A seguir apresentamos um quadro com os Estados, o número de experiências identificadas e a respectiva porcentagem em relação ao total levantado.

\begin{tabular}{|c|c|c|}
\hline ESTADO & QUANTIDADE & $\%$ \\
\hline SP & 94 & 26,85 \\
\hline PA & 37 & 10,57 \\
\hline RJ & 32 & 9,14 \\
\hline BA & 31 & 8,85 \\
\hline AM & 30 & 8,57 \\
\hline PE & 24 & 6,85 \\
\hline MG & 19 & 5,42 \\
\hline MA & 17 & 4,85 \\
\hline TO & 10 & 2,85 \\
\hline RR & 9 & 2,57 \\
\hline AP & 8 & 2,28 \\
\hline AC & 7 & 2 \\
\hline RO & 6 & 1,71 \\
\hline MT & 5 & 1,42 \\
\hline AL & 4 & 1,14 \\
\hline RS & 4 & 1,14 \\
\hline DF & 3 & 0,85 \\
\hline CE & 3 & 0,85 \\
\hline SC & 2 & 0,57 \\
\hline GO & 1 & 0,28 \\
\hline RN & 1 & 0,28 \\
\hline SE & 1 & 0,28 \\
\hline ES & 1 & 0,28 \\
\hline PR & 1 & 0,28 \\
\hline MS & 0 & 0 \\
\hline PB & 0 & 0 \\
\hline PI & 0 & 0 \\
\hline Total & 350 & $\mathbf{1 0 0}$ \\
\hline & & \\
\hline & & \\
\hline
\end{tabular}

Quadro 3 - Porcentagem de experiências identificadas por estado brasileiro. Fonte: o autor (2008) 
Não foram registradas experiências nos Estados do Mato Grosso do Sul, Paraíba e Piauí, o que não significa que não existam bibliotecas comunitárias nesses estados. Ficou evidente que a maioria dos grupos responsáveis por esses projetos tem muita dificuldade para divulgar suas ações. As informações sobre as experiências nas regiões norte, nordeste e centro-oeste foram levantadas a partir dos agentes coletivos que apóiam essas práticas, tal como a Associação Vaga Lume e o Instituto Ecofuturo, ou, ainda, em projetos de pesquisa sobre o assunto (PRADO, 2006; JESUS, 2007). Na região sudeste destacamos como fontes de informação para a coleta de dados os projetos de pesquisa da UNESP de Marília (BARROS e LEMOS, 2003), da UNIRIO (MACHADO, 2008) e as pesquisas e TCCs desenvolvidos por alunos da USP (MORISHITA, 2006; SÁ, 2007) e UNIRIO (FACCION JUNIOR, 2005; AMORIM, 2006; PUPPIN, 2008; SILVA, 2008).

No entanto, muitas das informações coletadas foram obtidas por meio da mídia impressa e digital. É fato que, apesar da disseminação da Internet no país, ainda são poucas as experiências que possuem um sítio na WEB; destacam-se, neste universo, a Biblioteca Comunitária Zumaluma ${ }^{15}$ e Biblioteca Solidária ${ }^{16}$ em São Paulo, a Biblioteca Comunitária Solano Trindade ${ }^{17}$, de Duque de Caxias no Rio de Janeiro e a Biblioteca Comunitária Maria das Neves Prado ${ }^{18}$, em São José do Paiaiá, Nova Soure, Bahia.

Dando continuidade à análise do conjunto de experiências, apontamos a preferência de seus idealizadores pelo emprego do termo "biblioteca comunitária" como denominação para esses espaços. Entretanto, cabe destacar a criatividade do nome adotado por um jovem estudante de Letras para identificar a biblioteca comunitária que criou dentro da borracharia da sua família, na cidade de Sabará, Minas Gerais - Borrachalioteca. De maneira criativa, combinando as características inerentes ao espaço, com as novas funções que lhe foi dado, criou uma marca para seu projeto.

As bibliotecas criadas com o apoio de organizações que desenvolvem projetos específicos na área levam o nome do projeto, criando assim uma marca para divulgar a ação, como por exemplo:

\footnotetext{
${ }^{15}$ Endereço eletrônico: www.zumaluma.com.br

${ }^{16}$ Endereço eletrônico: www.bibliotecasolidaria.com.br/

17 Endereço eletrônico: bibliotecasolanotrindade.blogspot.com/

18 Endereço eletrônico: www.geocities.com/mnpbiblio/pg_1.swf
} 
$\checkmark$ Biblioteca Vaga Lume, da Comunidade Boca da Mata - uma das 125 bibliotecas criadas pelo Programa Expedição Vaga Lume. Está localizada na comunidade indígena de Boca da Mata, no município de Pacaraima, Estado de Roraima;

$\checkmark$ Biblioteca Comunitária Ler é Preciso, de Magé - uma das 63 bibliotecas criadas pelo Programa Ler é Preciso do Instituto Ecofuturo. Está localizada na zona rural da cidade de Magé, no Estado do Rio de Janeiro.

Na mesma linha, encontramos a Biblioteca Comunitária T-Bone, em Brasília, que leva o nome do estabelecimento do qual seu idealizador é proprietário: Açougue T-Bone.

Outra denominação para esse tipo de experiência que se diferencia foi criada pelo operador de som, que se auto-intitula um "traficante de livros", a Livroteca Guardiã na comunidade do Bode, uma comunidade que vive em palafitas, no bairro do Pina, vizinho à sofisticada praia de Boa Viagem, na zona sul de Recife, Pernambuco (LINS, 2008). A título de curiosidade, a frase que abre esta seção está exposta em uma das paredes desse espaço. Tendo em vista as condições em que vivem, literalmente estão sentados na lama, resta-nos saber quantos estão olhando as estrelas.

As bibliotecas comunitárias criadas nas salas de velório da cidade de São Paulo também adotaram um nome curioso - Bibliotecas do Além. São espaços de leitura criados para ampliar o acesso ao livro e a leitura de coveiros, jardineiros e garis dos cemitérios paulistanos. Seu idealizador, Devanir Amâncio, explica que inicialmente pretendiam dar o nome de Biblioteca Comunitária dos Coveiros, porém consideraram que poderia assustar a comunidade do entorno e por isso optaram por Bibliotecas do Além.

A homenagem a uma personalidade local, santos e espíritos, ou ainda a escritores consagrados é recorrente, a exemplo da Biblioteca Comunitária Dona Zica, no Morro da Mangueira, Biblioteca Comunitária Emmanuel, no bairro de Magalhães Basto e a Biblioteca Comunitária Paulo Freire, no Complexo da Maré, todas na cidade do Rio de Janeiro.

Muitas optam por identificar a biblioteca exclusivamente pelo nome da comunidade, como o caso da Biblioteca Comunitária de Quixambeirinhas, em Nova 
Soure, Bahia, ou da Biblioteca Comunitária do Lajeado em Belo Horizonte, Minas Gerais.

Percebemos que para alguns grupos o nome dado à biblioteca é muito representativo, tanto no sentido de reforçar suas identidades, como no sentido de declarar seus pensamentos e sua forma de ver o mundo. Nesses casos, os nomes são criados a partir de uma reflexão sobre os objetivos que pretendem atingir com o projeto. Destacamos dois exemplos: a Biblioteca Comunitária Livro-Pra-Quê-TeQuero, na Vila Livieiro, cidade de São Paulo e a Biblioteca Comunitária Zumaluma, na favela do Inferninho na cidade de Embu das Artes, em São Paulo. Zumaluma é o termo criado a partir da conjunção dos nomes Zumbi do Palmares, Malcom X, Marthin Luther King e Nelson Mandela. Uma referência a líderes negros e representantes da luta pela liberdade e contra a discriminação racial.

Das 350 bibliotecas comunitárias encontradas, 33,42\% estão distribuídas nos grandes centros urbanos, considerados aqui como cidades com mais de um milhão de habitantes. Porém, a maioria, $66,57 \%$ do total, está localizada em zonas rurais de pequenos municípios, ou seja, bairros, vilas, fazendas, aldeias indígenas, assentamentos, comunidades ribeirinhas e ilhas.

\begin{tabular}{|c|c|}
\hline CIDADE & QUANTIDADE \\
\hline São Paulo & 63 \\
\hline Rio de Janeiro & 14 \\
\hline Salvador & 16 \\
\hline Fortaleza & 1 \\
\hline Belo Horizonte & 11 \\
\hline Brasília & 3 \\
\hline Curitiba & 1 \\
\hline Recife & 2 \\
\hline Porto Alegre & 2 \\
\hline Belém & 1 \\
\hline Guarulhos & 3 \\
\hline Total & $\mathbf{1 1 7}$ \\
\hline
\end{tabular}

Quadro 4 - Experiências identificadas em municípios com mais de um milhão de habitantes. Fonte: 0 autor (2008)

Com raras exceções, a grande maioria das bibliotecas cadastradas encontrase em áreas consideradas de exclusão, localidades carentes, de difícil acesso, seja pela distância, seja pela relação de vulnerabilidade em que se encontram. 
Evidencia-se que, na maioria dos casos, as localidades não possuem equipamentos culturais, como nas regiões rurais ou nas regiões periféricas dos grandes centros urbanos.

Encontramos também bibliotecas comunitárias localizadas em regiões nobres de grandes centros urbanos; no entanto, sediadas em zonas consideradas excluídas. Exemplos disso são as bibliotecas localizadas em Copacabana e Ipanema, situadas nas favelas Pavão, Pavãozinho e Cantagalo, na cidade do Rio de Janeiro, ou ainda a Biblioteca Comunitária Ler é Preciso da Coopamare, Cooperativa de Catadores Autônomos de Papel, Papelão, Aparas e Materiais Reaproveitáveis, no bairro de Pinheiros, na cidade de São Paulo, situada embaixo de um viaduto. Nesses casos, as regiões são ricas em equipamentos culturais, porém esses equipamentos são orientados para atender um público de poder aquisitivo maior. Retomando ao exemplo da biblioteca da Coopamare, seus usuários, moradores de rua, albergados e catadores de lixo, ao serem questionados por que não freqüentam a Biblioteca Pública "Alceu Amoroso Lima", localizada a duas quadras da biblioteca comunitária, respondem que não se sentem acolhidos naquele espaço. Um carroceiro nos diz "não tenho coragem de entrar lá descalço". Outro colega completa: "Uma vez entrei e um guarda começou a me seguir"

Outros aspectos importantes referem-se às questões que envolvem os motivos que levam ao surgimento desses espaços, o papel desempenhado pelos atores no processo de criação de bibliotecas denominadas como comunitárias e as articulações locais que garantem a sua sustentabilidade.

\subsection{OS MOTIVOS E OS ATORES PRINCIPAIS}

Num lugar em que as mulheres são mortas pelos maridos, agredidas pelos filhos, torturadas pelas mini-saias, saltos altos e outras "burcas" do Ocidente, escolhi casar e ter crias, e trabalhar na comunidade. Preta, pobre, favelada, escolho não estar à venda. Nascida na Rua dos Ossos, escolho formar consciências

(Dinha, Biblioteca Comunitária Livro-Pra-Quê-Te-Quero)

Das 350 bibliotecas cadastradas, 29 experiências foram selecionadas para compor o universo da pesquisa. Para acompanhar esta discussão, apresentamos, no apêndice $B$, o quadro 4 com o nome das bibliotecas selecionadas, sua 
localização, seus idealizadores, os principais atores, as formas de participação, algumas das parcerias estabelecidas e a forma de obtenção dos dados coletados.

Com base nesse universo foi possível identificar com maior clareza que o motivo principal que leva à criação desses espaços é a dificuldade de acesso ao livro e à leitura, ou seja, a carência de espaços públicos para esse fim - bibliotecas públicas e escolares. Isto faz com que cidadãos comuns, grupos de jovens, ou, ainda, organizações coletivas destinem esforços para a criação desses espaços.

Apesar do motivo desencadeador desse processo ser o mesmo, a forma como surge cada uma dessas bibliotecas e o seu estabelecimento na comunidade, seguem caminhos totalmente diferentes.

\subsubsection{Projetos criados a partir de iniciativas individuais}

Identificamos varias experiências que surgiram do simples desejo de uma pessoa, de um cidadão comum, abrir sua casa, ou sua biblioteca particular, para a comunidade. De uma maneira voluntária e seguindo princípios filantrópicos, esse agente individual organiza um espaço com o objetivo de compartilhar seu conhecimento e seu prazer pela leitura e, assim, contribuir para melhorar os níveis de leitura, educação e cultura da sua comunidade.

O professor Aziz Ab'Sáber é um exemplo de cidadão que vem dedicando anos de sua vida ao fomento de bibliotecas comunitárias pela cidade de São Paulo. Assim como ele, encontramos inúmeras pessoas, das mais diversas formações, muitos deles sem nenhuma escolaridade, contribuindo para ampliar o acesso ao livro e à leitura no país. São professores, estudantes, pescadores, pedreiros, borracheiros, açougueiros, catadores de lixo, enfim, cidadãos comuns, solidários, que assumem para si a responsabilidade de compartilhar aquilo que têm ou que aprenderam em suas vidas.

Das 29 experiências, 7 se enquadram nessa condição. São elas:

$\checkmark$ Biblioteca Solidária (SP), criada por um bibliotecário;

$\checkmark$ Biblioteca dos Garis (SP), criada por um ex-seminarista;

$\checkmark$ Biblioteca Comunitária T-Bone (DF), criada por um açougueiro; 
$\checkmark$ Biblioteca Comunitária Tobias Barreto (RJ), criada por um pedreiro;

$\checkmark$ Biblioteca Comunitária Prestes Maia (SP), criada por um catador de lixo;

$\checkmark$ Biblioteca Comunitária Maria das Neves Prado (BA), criada por um professor;

$\checkmark$ Biblioteca Comunitária de Poços de Caldas (MG), criada por um fazendeiro.

A Biblioteca Solidária localizada no Distrito de São Francisco Xavier, em São José dos Campos, no Estado de São Paulo, foi criada por um bibliotecário. Ao retornar a sua cidade natal, após alguns anos de experiência profissional, Sidnei P. Rosa propôs à Secretaria de Cultura daquele município a criação de uma biblioteca pública no seu distrito. Tendo em vista a recusa da proposta, decidiu montar uma biblioteca comunitária em sua casa. Desde 2004, o espaço passou a ser um dos pontos de encontro de crianças, estudantes, profissionais liberais, donas de casa e turistas que freqüentam a cidade.

Devanir Amâncio, ex-seminarista e idealizador da Biblioteca dos Garis, relata que teve uma infância pobre, morava no Paraná, na zona rural e sua família só tinha acesso à leitura porque seus pais, apesar de analfabetos, não deixavam de comprar livros dos mascates que batiam à sua porta. Todos os irmãos estudaram e hoje ele dedica sua vida à criação de campanhas de coleta e distribuição de livros para fomentar bibliotecas comunitárias pela cidade de São Paulo.

O açougueiro Luiz Amorim, de Brasília, criou a Biblioteca Comunitária T-Bone dentro do próprio açougue. Essa situação perdurou até que a vigilância sanitária fechou o açougue por causa da "convivência" indevida entre livros e carnes. Foi a partir desse incidente que a biblioteca foi transferida para uma casa próxima. Segundo ele, um apaixonado por livros, durante 11 anos a biblioteca foi custeada pelo açougue. Para nós, esse caso se aproxima dos conceitos de responsabilidade social e marketing cultural implementado por um pequeno comerciante local. Assim como a biblioteca, todas as outras atividades idealizadas e desenvolvidas por Amorim levam o nome do açougue. 


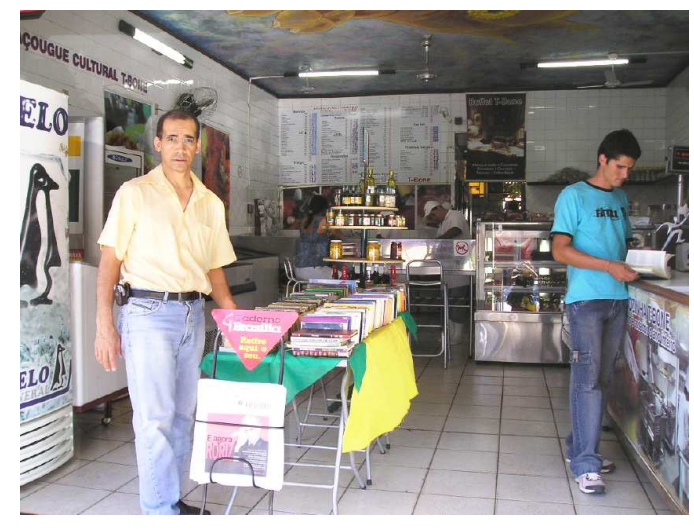

Figura 5 - Luiz Amorim no Açougue T-Bone Fonte: o autor (julho de 2007)

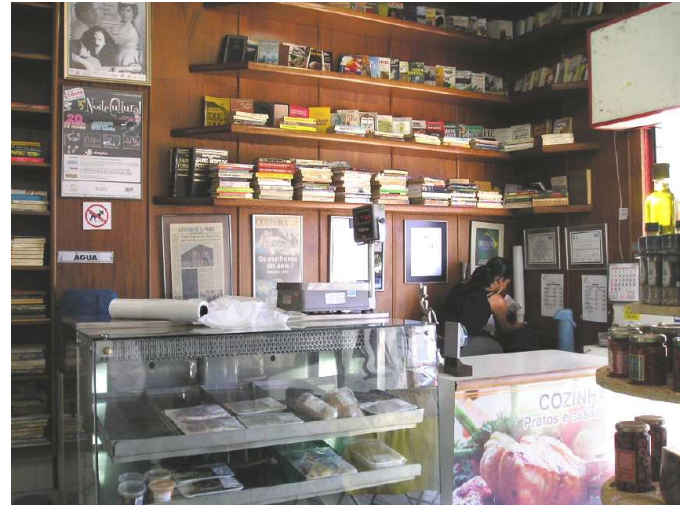

Figura 6 - Açougue T-Bone

Fonte: o autor (julho de 2007)

Em alguns desses casos, é evidente que, a partir dessa iniciativa, o agente individual muda sua posição no grupo e na sociedade e a biblioteca passa a ser o seu passaporte para integrar um novo grupo e, quem sabe um novo mundo. São os espaços sociais e as formas de poder que estão em jogo. Quando este fato passa a ser o motivo da existência da biblioteca, fecham-se as portas para a participação da comunidade e a biblioteca passa a ter um "dono".

No sítio de relacionamentos Orkut, encontrarmos muitos exemplos de pessoas que se identificam como proprietários de uma biblioteca comunitária. É o caso de Carlos Luiz que no seu perfil diz: "sou pedreiro e dono de uma biblioteca comunitária"19

A necessidade de determinados indivíduos de mudarem sua posição no espaço social é evidenciada quando elegem a biblioteca como um projeto individual. Com base no pensamento de Bourdieu (2005), podemos inferir que a biblioteca é vista por esses agentes individuais como um meio de ampliar o seu capital cultural e social, de maneira a torná-los diferentes na estrutura do campo de forças do qual fazem parte.

Evandro da Silva, o pedreiro que criou a Biblioteca Comunitária Tobias Barreto, no bairro da Penha, na cidade do Rio de Janeiro, é um exemplo disso. Transformou sua casa em um depósito de livros e, com a mídia a seu favor, conseguiu projeção nacional (ARRUDA, 2004; BNDES, 2005; VIANNA, 2006). No entanto, o projeto está centrado na sua pessoa, a ponto de não permitir nenhum tipo de organização do acervo. Desta forma, todas as pessoas que procuram sua casa

\footnotetext{
${ }^{19}$ Endereço eletrônico: www.orkut.com.br/Main\#FullProfile.aspx?uid=10930398526124640172
} 
passam a depender da sua presença e memória para encontrar um livro no emaranhado de pilhas que se espalham pelos cômodos de sua casa.

A Biblioteca Comunitária Prestes Maia, idealizada por um casal de catadores de lixo, Severino e Roberta, tem uma história semelhante à da Biblioteca Tobias Barreto. A idéia de recolher os livros do lixo levou o casal a organizar um espaço no porão do prédio invadido pelo Movimento dos Sem Tetos do Centro (MSTC) e oferecer esse acervo para consulta e empréstimo da comunidade moradora no local, na época, formada por 468 famílias, aproximadamente 2.000 pessoas. Cabe esclarecer que a ocupação era formada por trabalhadores formais e informais, desempregados, mães, jovens e crianças, com inúmeras e diferentes histórias e trajetórias pessoais, profissionais e espirituais. A ocupação era comandada por mulheres e estruturada em coordenação geral e coordenação de andares. Apesar da aparente simplicidade da organização, na realidade, o que aquele grupo vivenciava naquele espaço era uma complexa relação de sociabilidade, cheia de contradições, que mobilizava e impulsionava o grupo no sentido de desenvolver uma serie de práticas coletivas. Foi nesse ambiente que Severino e Roberta montaram a biblioteca e obtiveram projeção na mídia (BALAZINA, 2006).

A experiência da Prestes Maia guardava uma grande semelhança com a de Tobias Barreto, pelo fato de ser entendida como um "bem patrimonial" do casal e não do grupo que constituía a ocupação. Ou seja, era um espaço aberto à coletividade, mas não da coletividade. Isso foi evidenciado no momento da negociação para a saída do prédio, encaminhada pela Prefeitura. A desocupação tinha como objetivo remover e realocar essas pessoas para as periferias da cidade $\mathrm{e}$ gerou inúmeros conflitos, inclusive sobre o destino do acervo. O projeto de Severino e Roberta colaborou para que os dois se desligassem do movimento. Hoje o casal continua com seu projeto, que acabou ganhando um novo nome, Biblioteca Machado de Assis, na Chácara Santa Maria, na cidade de Itapecerica da Serra.

Entretanto, é importante ressaltar casos em que a biblioteca foi criada por uma pessoa e esta se coloca na posição de membro da comunidade e, por meio de ações pedagógicas, vai construindo estratégias, com maior ou menor impacto, para que o projeto que começou como uma ação individual, se transforme numa ação coletiva. Essas pessoas conhecem as dificuldades locais e acreditam que sozinha a comunidade não vai criar uma biblioteca, ela precisa de alguém que elabore esta proposta. É o caso das bibliotecas Maria das Neves, na Bahia, criada por um 
professor, e a de Poços de Caldas, em Minas Gerais, criada por um fazendeiro. $\mathrm{Na}$ seção reservada para discutir as formas de participação retornaremos a essas duas experiências.

\subsubsection{Projetos criados a partir de iniciativas coletivas}

Diferentemente das iniciativas individuais, encontramos também experiências em que a motivação para a criação desses projetos parte de agentes coletivos internos e/ou externos à comunidade.

Identificamos que a maioria dos agentes coletivos internos a comunidade são representados por grupos de jovens, organizados em movimentos sociais locais. Já os agentes coletivos externos à comunidade apresentam-se na figura de organizações não governamentais, vinculadas ou não a instituições privadas. As organizações que trabalham nesse sentido são provenientes das mais variadas áreas, institutos e fundações vinculadas a empresas, a instituições educacionais, assim como organizações caracterizadas como cooperativas, associações de bairros, escolas de samba e entidades religiosas, ou, ainda, organizações não governamentais criadas especificamente para esse fim.

5.2.2.1 Projetos criados a partir de iniciativas coletivas externas à comunidade

Das 29 experiências analisadas, 15 foram criadas por agentes coletivos externos à comunidade, ou seja, pouco mais da metade. São elas:

$\checkmark$ Associação Expedição Vaga Lume, 6 experiências;

$\checkmark$ Fundação Fé e Alegria do Brasil e Sociedade Santo Mártires, 1 experiência;

$\checkmark$ Instituto de Cidadania Empresarial (ICE), 1 experiência;

$\checkmark$ Instituto Ecofuturo, 4 experiências;

$\checkmark$ Obra São João Baptista, 1 experiência; 
$\checkmark$ TV Globo, 1 experiência;

$\checkmark$ Solar Meninos de Luz, 1 experiência.

É importante destacar o grande número de bibliotecas criadas por organizações religiosas no Brasil. Nesse grupo encontram-se experiências que têm o caráter solidário e filantrópico, que criam a biblioteca com o objetivo de apoiar as crianças e jovens no desenvolvimento escolar. É o caso das seguintes experiências:

$\checkmark$ Biblioteca Comunitária Paulo Coelho, no morro Pavão e Pavãozinho, no Rio de Janeiro, vinculada ao Solar Meninos de Luz;

$\checkmark$ Biblioteca Comunitária Emmanuel, no Bairro de Magalhães Bastos no Rio de Janeiro, vinculado à Obra São João Baptista;

$\checkmark$ Biblioteca Comunitária Cultura Jovem, do Jardim Ângela, na cidade de São Paulo, criada pela Fundação Fé e Alegria do Brasil e Sociedade Santo Mártires.

O primeiro exemplo refere-se a uma biblioteca que, apesar do nome, caracteriza-se como uma biblioteca escolar, pois atende exclusivamente as demandas advindas da Creche-Escola Meninos de Luz. Já nos dois outros exemplos, por sua forma de gestão, que estimula o envolvimento da comunidade local, os projetos se aproximam mais do conceito de biblioteca comunitária proposto neste trabalho.

No entanto, algumas bibliotecas criadas por instituições religiosas utilizam deliberadamente seu espaço e seu acervo de maneira ideológica. As rodas de leitura, por exemplo, são realizados com base em textos religiosos. Esse fato foi identificado com maior clareza, nos pequenos municípios que fazem parte da pesquisa "Bibliotecas comunitárias no semi-árido brasileiro" (PRADO, 2006).

A Associação Vaga Lume é uma ONG sem qualquer vínculo religioso ou empresarial e foi criada com o objetivo principal de ampliar o acesso ao livro e à leitura em comunidades rurais da região amazônica. Entre seus objetivos específicos, destacamos o estímulo ao exercício de gestão comunitária das bibliotecas implantadas no Programa Expedição Vaga Lume (ASSOCIAÇÃO VAGA LUME, 2005). 
Para atingir esse objetivo, a equipe inicial do programa foi formada na metodologia de mediação de leitura desenvolvida pela A Cor da Letra: Centro de Estudos em Leitura e Literatura e a partir daí desenvolveu um plano de ação que, hoje, prevê a articulação com as prefeituras, as secretarias de educação, os professores e as lideranças locais:

A metodologia está fundada no tripé estrutura-capacitação-gestão, ou seja, na concepção de que a entrega de recursos materiais deve vir acompanhada da capacitação de pessoas para utilizá-los e do estabelecimento de rotinas para a inserção no cotidiano (ASSOCIAÇÃO VAGA LUME, [2006?], p. 6).

Na Amazônia, em sua maioria, o espaço eleito para servir de apoio para o projeto é a escola local, visto que são localidades longínquas, de difícil acesso, onde a praça, a igreja, a escola e o posto de saúde são os pontos centrais da comunidade. Nesses casos, apesar de se denominarem bibliotecas comunitárias na tipologia biblioteconômica, a maioria das Bibliotecas Vaga Lume (BVL) se caracterizariam como bibliotecas escolares. É o caso das bibliotecas Vaga Lume da comunidade ribeirinha de Vista Alegre em Caracaraí e da comunidade Boca da Mata, em Pacaraima, ambas no Estado de Roraima, assim como da comunidade Corre Água de Piririm em Macapá, no Estado do Amapá.

Entretanto, é importante ressaltar que, nos três casos citados acima, apesar da biblioteca estar sediada numa escola, a comunidade se apropriou do espaço graças à ação participativa implementada por seus coordenadores. Marinho Soares da Silva, morador da comunidade e responsável pela Biblioteca Vaga Lume da Comunidade de Vista Alegre, colocou um cartaz na porta da biblioteca com os seguintes dizeres: "Não passe sem entrar; não entre sem olhar; não olhe sem pegar; não saia sem levar." Esse convite declara que a biblioteca não tem como único foco as ações escolares e está aberta a todos os membros da comunidade.

Em entrevista, os coordenadores deixaram bem claro que o fato dessas bibliotecas estarem sediadas na escola é apenas uma questão contingencial. $O$ princípio de participação nas comunidades de Corre Água do Piririm, Boca da Mata e Vista Alegre, faz parte da cultura local, visto que preservam os hábitos e costumes indígenas, que valorizam o processo democrático de tomada de decisão. 
Vivemos em comunidade, com nossas lendas, mitos e pagés. Nossa história real é de luta dos povos indígenas em defesa da terra e da preservação da cultura indígena.

(Sérgio da Silva Pereira Macuxi, membro da comunidade do Barro e da União do Povo Macuxi)

É importante dizer que as escolas naquela região não são iguais àquelas que conhecemos nas outras regiões do país, são construídas no formato de maloca e são bilíngües, pois, a partir da luta dos professores indígenas, conseguiram implementar a língua materna além do ensino da língua portuguesa no currículo escolar. A escola da comunidade Boca da Mata, por exemplo, que fica na reserva Raposa Serra do Sol e é formada pelos povos Macuxi, Wapichana, Ingaricó, Taurepang e Patamona, contemplam em seu currículo o ensino de 4 línguas, o português, o macuxi, o wapichana e o taurepang.

Um caso relatado pelas coordenadoras do programa ilustra bem esta questão. Quando os integrantes da comunidade de Taquari, no município de Ponte Alta do Tocantins, souberam que a escola local seria transferida para outra comunidade, foram para a porta da escola e disseram: "a escola pode ir, mas a biblioteca é da comunidade". E assim preservaram o acervo junto à comunidade e criaram um espaço para ela na casa de um morador local.

Cabe esclarecer que não é regra que as bibliotecas criadas pela Expedição Vaga Lume fiquem sediadas na escola, a escolha faz parte de uma decisão da comunidade. Segundo eles, "cada intervenção é planejada e adaptada às condições da realidade local" (ASSOCIAÇÃO VAGA LUME, 2005). Exemplo disso é a Biblioteca Vaga Lume da Comunidade Santa Tereza, localizada no município de Mirinzal no Estado do Maranhão. O projeto, sob a liderança de um morador local, Carlos Magno Martins Farias, teve seu início num espaço cedido pela escola. Porém, ao longo do tempo, a comunidade Quilombola de Santa Tereza, formada por 35 famílias, com 99 pessoas, se reuniu e decidiu transferir o acervo para a sala da casa de um dos moradores locais, a qual ficou reservada somente para uso da biblioteca. Em visita ao local, uma das coordenadoras do Projeto, Joana Arari, intrigada com a escolha do local, perguntou ao dono da casa se ele não se incomodava com o fato das pessoas entrarem e saírem, dia e noite, da sua casa. Ele respondeu que não e justificou: "eu vivo sozinho e com a biblioteca a casa ficou muito mais alegre". 


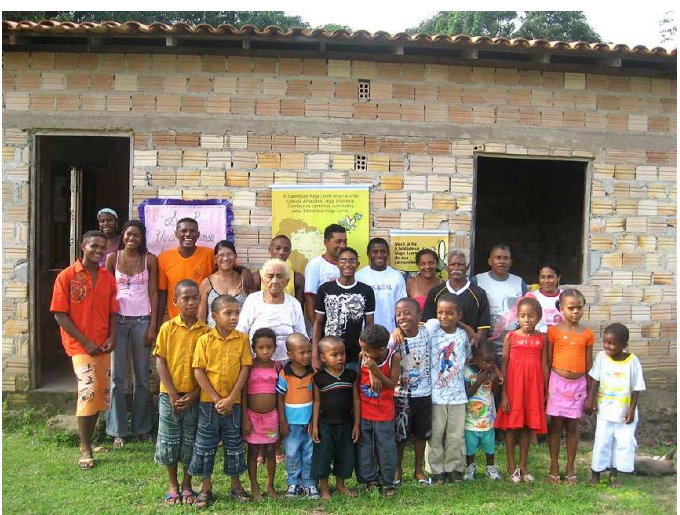

Figura 7 - BVL da Comunidade de Santa Tereza Fonte: Acervo Associação Vaga Lume

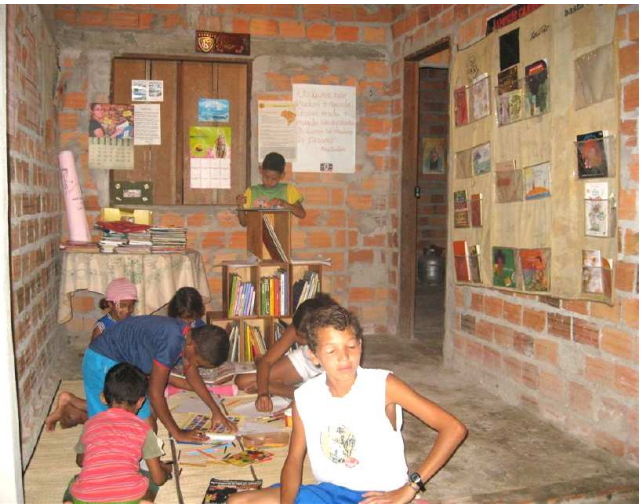

Figura 8 - BVL da Comunidade de Bengui Fonte: Acervo Associação Vaga Lume

A Biblioteca Vaga Lume da Comunidade Bengui, na periferia da cidade de Belém, uma experiência que se diferencia no conjunto de iniciativas do Programa, por estar localizada num grande centro urbano, também conseguiu criar o seu próprio espaço na casa de uma mediadora de leitura formada pelo programa. $\mathrm{O}$ acervo, que inicialmente só podia ser utilizado pelos alunos da escola local, passou a ser disponibilizado para todos os moradores da comunidade. Hoje a biblioteca funciona durante os dias da semana até as $21 \mathrm{hs}$ e passou a ser uma extensão da escola. Segundo relato da professora Ana Maria Cabral da Gama, antes as crianças saiam da escola e ficavam na rua e hoje elas intercalam a brincadeira de rua com a leitura, visto que entram e saem da biblioteca o dia todo. "Se as crianças gostam de ler na escola, porque não levamos a biblioteca para fora da escola?"

O bairro de Bengui é uma das regiões mais pobres da cidade de Belém. Possui apenas 2 ruas pavimentadas. Os poucos serviços públicos estão em situação precária, não conta com espaços culturais, a não ser aqueles criados pela própria comunidade.

A coordenação da Expedição Vaga Lume relata que, após o primeiro ano de trabalho, ficou clara a necessidade de monitoramento das bibliotecas. Antes de iniciar o processo de criação de novas unidades foi preciso investir na formação de multiplicadores locais para acompanhar o desenvolvimento das atividades, identificando problemas, propondo soluções e diagnosticando a possibilidade de implantação de novas unidades no município. Hoje o Programa conta com mais de 1.000 multiplicadores locais. É uma verdadeira rede de mediadores de leitura locais que trabalham no sentido de fomentar a participação das comunidades nas práticas 
desenvolvidas pelas bibliotecas Vaga Lume e colaborar na criação de novas bibliotecas.

O reconhecimento da importância do monitoramento foi um dos motivos que levou a coordenação a restringir a atuação do Programa em 20 cidades dos 9 estados que compõem a região da Amazônia Legal Brasileira. São elas: Capinápolis e Chapada dos Guimarães, no Mato Grosso; Ouro Preto do Oeste, em Rondônia; Cruzeiro do Sul, no Acre; Carauari, Tefé, São Gabriel da Cachoeira e Barcelos, no Amazonas; Pacaraima e Caracaraí, em Roraima; Macapá, no Amapá; Oriximiná, Santarém, Portel, Soure, Castanhal e Belém, no Pará; Mirinzal e Barreirinhas, no Maranhão e Ponte Alta do Tocantins, no Estado do Tocantins.

O Projeto Ler é Preciso, por sua vez, uma ação de responsabilidade social do Instituto Ecofuturo, vinculado as empresas Suzano Papel e Celulose e Suzano Peroquímica, diferentemente da Associação Vaga Lume, tem por objetivo principal a criação de bibliotecas comunitárias. Das 70 bibliotecas implantadas pelo programa até dezembro de 2007, tivemos contato direto com as quatro bibliotecas abaixo relacionadas:

$\checkmark$ Biblioteca Comunitária Ler é Preciso Diuner Mello de Taquari, Paraty, RJ;

$\checkmark$ Biblioteca Comunitária Ler é Preciso de Magé, RJ;

$\checkmark$ Biblioteca Comunitária Ler é Preciso de Copacabana, Rio de Janeiro, RJ;

$\checkmark$ Biblioteca Comunitária Ler é Preciso da Coopamare, São Paulo, SP.

Para nós, das 4 experiências acima citadas, somente a biblioteca da Coopamare pode ser considerada uma biblioteca comunitária, pois o Instituto Ecofuturo agiu como um estímulo e apoiador para uma iniciativa que fazia parte do desejo da comunidade de catadores de lixo e o grupo, pela experiência de atuação na cooperativa, incorporou os princípios de participação na gestão da biblioteca.

Tanto a biblioteca de Paraty, localizada na zona rural de Taquari, como a biblioteca de Magé, localizada na zona rural de Conceição de Suruí, foram incorporadas pela escola local e ambas assumiram a função exclusiva de biblioteca escolar, diferentemente das experiências na região norte do país, relatados anteriormente.

Já a biblioteca de Copacabana é, na realidade, uma biblioteca pública, hoje com o nome Biblioteca Popular Municipal Infantil Max Feffer de Copacabana em 
homenagem ao ex-presidente do Grupo Suzano e do Instituto Ecofuturo. Por meio de uma parceria junto à Secretaria Municipal das Culturas, da cidade do Rio de Janeiro, o Grupo Suzano e a Associação Cultural e Beneficente Beit Lubavitch, o Instituto Ecofuturo articulou a melhoria de um órgão público, doando livros, mobiliário e formação da equipe. Portanto, apesar de ter sido divulgado e constar da relação de bibliotecas comunitárias criadas pelo Instituto Ecofuturo, trata-se de apoio a uma biblioteca pública.

Outra iniciativa coletiva que colaborou para a criação de uma biblioteca comunitária é o Projeto Casulo. O Projeto foi criado pelo Instituto de Cidadania Empresarial (ICE) com o objetivo de estimular o desenvolvimento comunitário dos moradores do Real Parque e Jardim Panorama, na cidade de São Paulo, e prioriza o trabalho com jovens daquela comunidade. É importante ressaltar que o Parque Real e o Jardim Panorama ficam localizados no Morumbi, o bairro com maior renda média da cidade de São Paulo segundo o IBGE, e que possui uma favela não urbanizada, com mais de 4.000 pessoas vivendo em barracos e conjuntos habitacionais. A ausência de políticas públicas para atuar junto ao grupo levou a sociedade civil, por meio de uma organização não governamental, o ICE, a se organizar e criar meios para agir no lugar do Estado.

O ICE começou seu trabalho fazendo um diagnóstico local para conhecer quem eram as pessoas que viviam no Parque Real e no Jardim Panorama e identificar quais eram as suas maiores necessidades. Ao constatar que $16 \%$ daquela população era analfabeta e que somente $9,5 \%$ buscavam informação na leitura, elegeram o acesso ao livro e à leitura como um dos focos de suas ações. Naquela época, uma criança ou jovem do Parque Real ou do Jardim Panorama que precisasse fazer uma pesquisa escolar tinha que se deslocar, a pé, até Paraisópolis, a 2 km de distância.

O primeiro passo foi a formação de jovens mediadores de leitura e na seqüência a discussão de como deveria ser a biblioteca do Parque Real e do Jardim Panorama. No entanto, como esses jovens poderiam responder essa questão, se suas vivências de leitura na escola e de biblioteca eram tão sofridas ou quase inexistentes? Nesse sentido, decidiram por iniciar uma pesquisa sobre o assunto e visitar bibliotecas públicas e universitárias para criar seus próprios parâmetros. Foi a Biblioteca Pública Monteiro Lobato, localizada na região central da cidade, que despertou o encantamento no grupo. Livros expostos, de fácil acesso, ambiente 
agradável e aconchegante; era o que desejavam. Cabe esclarecer que a formação dos jovens contou também com a consultoria da A Cor da Letra.

As três organizações citadas, Associação Expedição Vaga Lume, Instituto Ecofuturo e o ICE, têm a preocupação em eleger membros da comunidade para atuar no processo de implantação e manutenção das bibliotecas. Para isso, prevêem em seus projetos a formação desses agentes, fazendo com que membros da comunidade sejam os atores do processo. Mais adiante vamos ver como isso se dá efetivamente.

Já a TV Globo, conta com a parceria da ONG Viva Rio, na administração do Espaço Criança Esperança, na cidade do Rio de Janeiro. A biblioteca foi criada com o sentido de complementar uma gama de atividades educacionais e culturais oferecidas aos moradores das favelas do Cantagalo, Pavão e Pavãozinho. As pessoas que atuam nessa biblioteca não fazem parte da comunidade, são funcionários contratados pela ONG Viva Rio.

\subsubsection{Projetos criados a partir de iniciativas coletivas internas à comunidade}

Como já vimos anteriormente, os movimentos sociais são outro tipo de agente coletivo que trabalha no sentido de criar bibliotecas comunitárias. Sete experiências com estas características fazem parte deste universo. São elas:

$\checkmark$ Biblioteca Confraria dos Parceiros de Guararema, criada pelo MST na cidade de Guararema, SP;

$\checkmark$ Biblioteca Comunitária Paulo Freire, criada por um grupo de moradores da Maré, na cidade do Rio de Janeiro, RJ;

$\checkmark$ Biblioteca Comunitária Livro-Pra-Quê-Te-Quero, criada pela Posse Poder e Revolução, movimento juvenil da Vila Livieiro, Jardim Savério, no Parque Bristol, na cidade de São Paulo, SP;

$\checkmark$ Biblioteca Comunitária Solano Trindade, criada pelo grupo de jovens integrantes do Núcleo Cultural Força Ativa, no bairro de Cidade Tiradentes, na cidade de São Paulo, SP; 
$\checkmark$ Biblioteca Comunitária Zumaluma, criada por um grupo de jovens moradores da favela Inferninho, na cidade de Embu das Artes, SP;

$\checkmark$ Biblioteca Comunitária de Heliópolis, criada como parte do Projeto Identidade Cultural de Heliópolis, na cidade de São Paulo, SP;

$\checkmark$ Biblioteca Comunitária Prof. Waldir de Souza Lima, criada por um grupo de jovens moradores da cidade de Itu, SP.

O perfil da Biblioteca Confraria dos Parceiros de Guararema se diferencia nesse grupo por ter sido criada para apoiar o ensino e a pesquisa da Escola Florestan Fernandes, do MST. Suas características são de uma biblioteca universitária que, assim como muitas do país, atende também a comunidade local.

As outras 6 experiências surgiram do desejo da comunidade. Em um dos casos, o de Heliópolis, estimulada e apoiada por agentes externos, e nos outros casos, criadas de maneira espontânea, a partir da necessidade identificada pelo grupo.

A Biblioteca Comunitária Paulo Freire surgiu dentro do Centro de Estudos e Ações Solidárias da Maré (CEASM), organização sem fins lucrativos, criada em 1997, a partir da iniciativa de um grupo de moradores locais que tinham em comum a formação universitária e a trajetória de militância em movimentos sociais nas comunidades da Maré. O Complexo da Maré é formado por 16 comunidades, com mais de 132 mil habitantes, localizado entre a Av. Brasil e a Linha Vermelha, às margens da Baía de Guanabara. Com o objetivo de enfrentar e superar as condições de pobreza e exclusão do bairro, o CEASM definiu como uma de suas primeiras intervenções a criação do Pré-Vestibular Comunitários Maré (CPV- Maré). Foi nesse contexto que a idéia de criar um espaço de leitura e troca de livros se consolidou, tendo em vista a necessidade de estudo e compartilhamento dos poucos materiais de apoio ao ensino que os jovens possuíam. Ao longo do tempo, alguns desses jovens entraram nos cursos de Biblioteconomia e Arquivologia da UNIRIO e, levando o assunto para a Universidade, conseguiram o apoio da direção da Escola, que desenvolveu um projeto de extensão que previa o envolvimento dos alunos na organização do acervo e manutenção dos serviços da nova biblioteca. Hoje a biblioteca atende não só alunos pré-vestibulandos e universitários, mas também crianças, jovens e adultos moradores locais. 
$\mathrm{Na}$ mesma linha encontramos a Biblioteca Comunitária Livro-Pra-Quê-TeQuero, que surgiu dentro do movimento Posse Poder e Revolução, criado em 1999, no Parque Bristol, cidade de São Paulo. Posse é o movimento que reúne vários grupos de rappers, grafiteiros, MCs (mestre de cerimônia) músicos e simpatizantes do Hip Hop. A Posse Poder e Revolução era formada, na época, por 40 jovens que declararam, na sua carta de princípios, que um dos objetivos do grupo era criar uma biblioteca comunitária. Durante as intervenções culturais que o movimento organizava, eram arrecadados livros para suprir a necessidade de estudos daqueles que estavam se preparando para enfrentar o vestibular. Assim como o Complexo da Maré, na cidade do Rio de Janeiro, o Jardim Savério também é uma região desprovida de equipamentos culturais na cidade de São Paulo. No início, o grupo teve muita dificuldade em encontrar um espaço para abrigar aquele acervo e isso fez com que, por um ano, os livros ficassem no quarto de um dos jovens.

Como o Vander dormia por cima dos livros ele era conhecido como o rapaz mais culto do bairro. E, por osmose, entrou naquele ano na Faculdade de Educação da USP.

(Dinha, Biblioteca Comunitária Livro-Pra-Quê-Te-Quero)

Somente em 2004 inauguraram a Maloca Espaço Cultural, um espaço conquistado por meio da parceria com a Companhia de Desenvolvimento Habitacional e Urbano do Estado de São Paulo (CDHU) e o Instituto Brasileiro de Estudo e Apoio Comunitário (IBEAC). É a Maloca que abriga a Biblioteca Comunitária Livro-Pra-Quê-Te-Quero. Segundo Dinha, "até então, o que tínhamos era uma biblioteca particular, restrita aos integrantes do movimento".

A Biblioteca Comunitária Solano Trindade, por sua vez, também surge como um espaço de apoio ao estudo e à pesquisa de jovens ligados a um movimento do Hip Hop, o Núcleo Cultural Força Ativa. Em 1994, percebendo a necessidade de estimular a leitura e o acesso à informação para melhorar o processo de criação dos jovens envolvidos no movimento Hip Hop, um dos integrantes fez uma música intitulada "Vamos ler um livro" (ANEXO A). No entanto, logo perceberam que era muito difícil incentivar a leitura sem acesso a documentos textuais, ou seja, sem bibliotecas públicas na região. A biblioteca mais próxima ficava em Guaianases. Foi assim que se iniciou a mobilização para a criação da biblioteca comunitária como 
forma de denuncia da ausência desses espaços em Cidade Tiradentes. Somente em 2001, o grupo conseguiu inaugurar a Biblioteca Comunitária Solano Trindade.
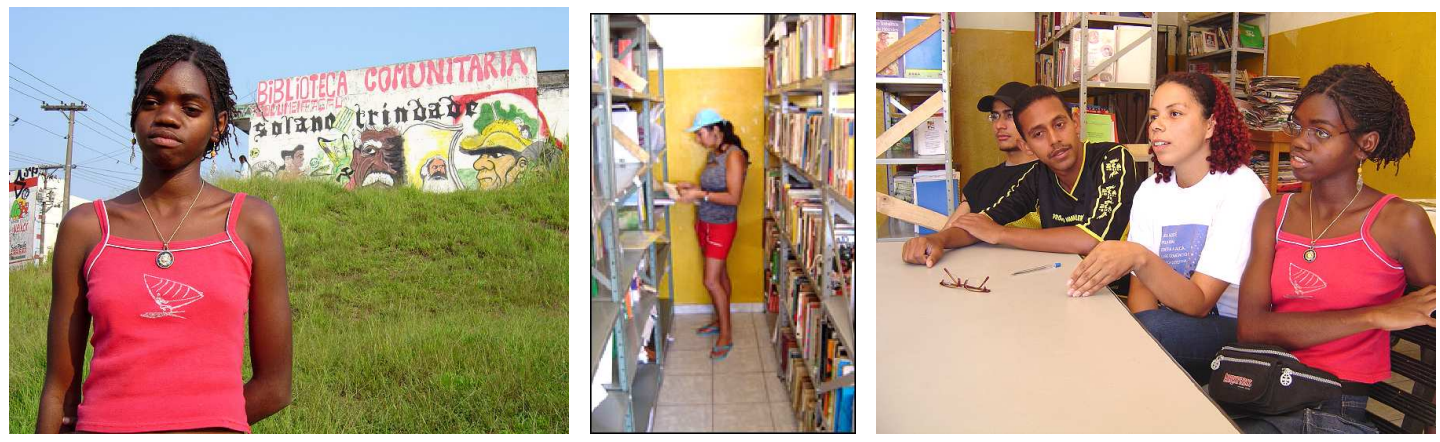

Figura 9-11 - BC Solano Trindade.

Fonte: Acervo Aracati

O movimento Força Ativa, que surgiu em 1989, tem como proposta promover a conscientização cultural, social e política da comunidade local. Assim como o Poder e Revolução, o Força Ativa é formado por jovens, com participação equilibrada de homens e mulheres, em sua maioria negros e estudantes, sendo que muitos são cantores de rap. Em varias falas e letras de músicas eles nos explicam os motivos que os levam a se envolver nesses movimentos (ANEXO B). Fernanda, moradora de Cidade Tiradentes, estudante de História na PUC-SP e integrante do Força Ativa diz o seguinte:

Eu quero que as pessoas se conheçam na própria história, que leiam um livro e se reconheçam naquela que estão lendo, que tenham conhecimento de um fato histórico e se reconheçam naquele fato histórico [...] é isso o que a gente está tentando [...] (FERNANDA apud DUARTE, 2006, p. 56).

Esses dois movimentos lutam pela consciência racial, igualdade de gênero, igualdade de direitos e oportunidades. Para isso, organizaram grupos de estudos e dedicam seus finais de semana para ler, refletir e debater esses temas. Numa manhã de domingo do mês de julho de 2008, tivemos a oportunidade de participar de um encontro do grupo, na Biblioteca Comunitária Solano Trindade, com mais de 16 jovens, onde o tema eleito era "democracia e cidadania" e o ponto de partida um texto de Habermas.

Suas formas de pensar e atitudes são afirmadas em seus cotidianos. Maria Nilda de Mota Almeida, mais conhecida como Dinha, escritora, mestranda da Faculdade de Filosofia Letras e Ciências Humanas da USP, moradora da Vila 
Livieiro e integrante da Posse Poder e Revolução, em artigo sobre a mulher, publicado no Le Monde Diplomatique Brasil declara

Nós vamos mudar o mundo acreditando nas bases, liderando um exército de crianças, nos armando de dentro pra fora, cuidando das nossas crias, negando a acumulação financeira capitalista, suas invenções protecionistas (machismo, racismo etc.) e sua censura [...] (DINHA, 2008, p. 21)

Já os jovens que criaram a Biblioteca Zumaluna declaram que a iniciativa foi tomada por ser esse o único caminho que encontraram, naquele momento, em oposição ao trafico de drogas. A maioria, jovens, homens, negros, moradores da favela Inferninho, desempregados e sem perspectivas, resolveram ocupar uma casa abandonada, utilizada, na época, como espaço para o consumo e trafico de drogas e prostituição. Declaram que a idéia partiu de um dos jovens do grupo, Cesar Mateus Rosalino, mais conhecido como "Vulto". Inicialmente, alguns acharam uma loucura, mas foram se unindo, organizaram um mutirão para a reforma da casa e se agarraram ao sonho de fazer algo diferente e importante.

Nós éramos ingênuos e achávamos que iríamos mudar o mundo

(Bisturi, integrante da Associação Zumaluma)

Um dos maiores problemas enfrentados pelo grupo foi com a polícia. Segundo Renato Nunes da Silva, mais conhecido como "Bisturi', "eles entravam na biblioteca diariamente armados e intimidando a todos". A polícia não acreditava que os jovens estavam ali para outra coisa que não fosse o consumo e trafico de drogas. Foi necessária a ajuda de um advogado, que encaminhou um ofício à polícia explicando o projeto de criação da biblioteca.
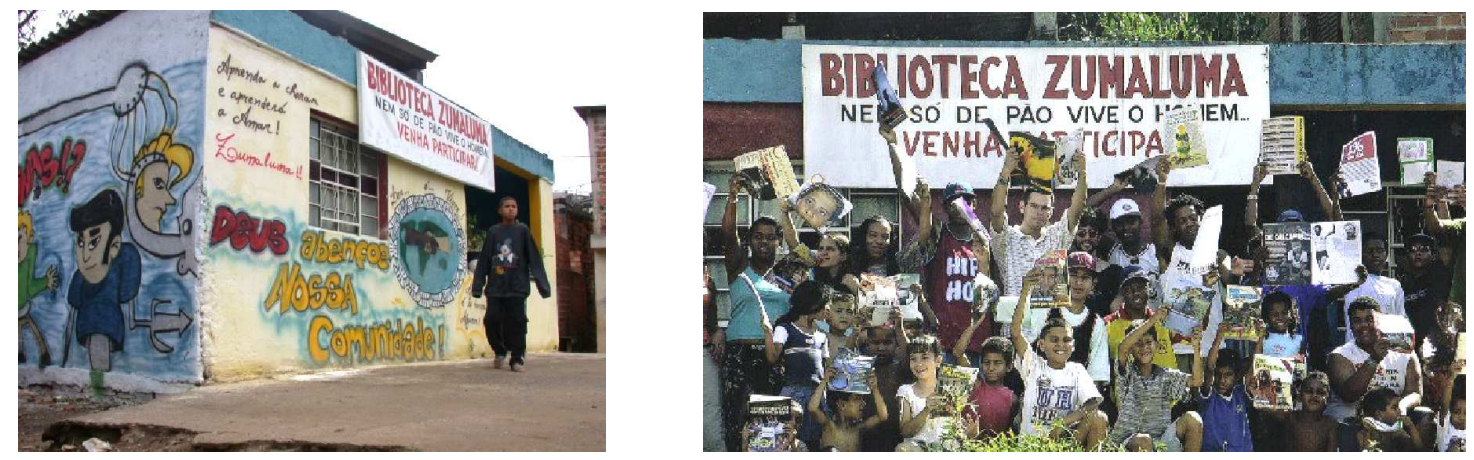

Figura 12-13 - Biblioteca Comunitária Zumaluma Fonte: sítio da biblioteca (www.zumaluma.com.br) 
A história de criação da Biblioteca Comunitária de Heliópolis é um pouco diferente, pois contou com o estímulo e apoio de agentes externos. A biblioteca é parte de um plano de ação denominado "Programa de Identidade Cultural de Heliópolis", concebido pelo arquiteto Ruy Ohtake em conjunto com a comunidade local. Foi a partir de várias reuniões e discussões com moradores, jovens da comunidade e especialistas, realizadas na sede da União de Núcleos, Associações e Sociedades dos Moradores de Heliópolis e São João Clímaco (UNAS), que o grupo elegeu um dos seus muitos sonhos, a biblioteca, como prioridade da comunidade.

Já a idéia de criar a Biblioteca Comunitária Prof. Waldir de Souza Lima surgiu de um grupo de jovens "agitadores culturais" de Itu, inconformados com a falta de opções culturais na cidade. A cidade de Itu, localizada no Estado de São Paulo, conta com cerca de 150 mil habitantes e possui uma única biblioteca pública que funciona de $2^{\mathrm{a}}$. a $6^{\mathrm{a}}$. feira, das $8 \mathrm{hs}$ às $17 \mathrm{hs}$. Segundo José Renato Galvão, o grupo se mobilizou para "montar uma biblioteca que oferecesse uma alternativa de horário, aos finais de semana e dias de semana à noite, e de acervo, além dos clássicos, [queríamos] livros e periódicos de autores e editoras independentes". O movimento que criou a biblioteca de Itu é formado por jovens e adultos que acreditam no potencial transformador da leitura e estão envolvidos em atividades profissionais ou acadêmicas nas áreas de Letras, Fotografia, Cinema, Artes Cênicas e Filosofia.

\subsection{PARTICIPAÇÃO, ARTICULAÇÃO E SUSTENTABILIDADE}

Para você pensar em participação política você tem que ter, no mínimo, condição de pensar, você tem que ter as suas condições objetivas resolvidas.

(Washington Góes, estudante de Letras da PUC e ativista do Força Ativa)

Pudemos perceber que existem formas diferentes de entender a participação, de participar nesses projetos e de articular e gerar recursos para a sustentabilidade das bibliotecas. 
5.3.1 As diferentes formas de entender a participação

De maneira geral pudemos identificar que o nível de participação dos membros das comunidades nos projetos de biblioteca não é alto. Em alguns casos podemos afirmar que não há participação no sentido de envolvimento das pessoas na tomada de decisão e no controle de recursos. São exemplos as bibliotecas Tobias Barreto, Prestes Maia, Paulo Coelho, dos Garis, T-Bone, Solidária e Criança Esperança. Apesar das grandes diferenças entre essas experiências é evidente que, nesses casos, a participação é confundida com a utilização dos serviços e o acesso ao espaço e aos materiais. É confundida também com trabalho voluntário, ou ainda, com o fato de seus coordenadores optarem por contratar pessoas da comunidade para trabalhar no projeto.

Os casos em que a participação é entendida como a doação de tempo para atuar no projeto na condição de voluntário são aqueles em que membros da comunidade são incentivados a desenvolver tarefas pré-determinadas com o intuito de viabilizar o projeto. Esta concepção é muito evidente na Biblioteca Comunitária Cultura Jovem e na Biblioteca Comunitária Emmanuel, as duas criadas por instituições religiosas que baseiam suas ações no princípio da filantropia e do voluntariado. No entanto, percebe-se também que, nos dois casos, como os voluntários assumiram a liderança do projeto, estes acabaram conquistando espaço nas respectivas organizações para a tomada de decisão.

No caso da Biblioteca Comunitária de Heliópolis, apesar da idéia da criação da biblioteca ter partido da comunidade, o nível de participação na sua gestão é muito baixo. Isto se dá, principalmente, pela falta de mecanismos que garantam essa participação, ou seja, os jovens monitores não têm experiência suficiente para administrar processos participativos e acabam agindo como funcionários da UNAS. Esta entidade, por sua vez, não estimula essa prática e age, em determinados momentos, de maneira autoritária e centralizadora. O resultado é que a biblioteca é vista pelos moradores da favela de Heliópolis como mais um serviço oferecido pela UNAS.

O mesmo acontece com a Biblioteca Comunitária Paulo Freire, da Maré, que acabou se constituindo como uma unidade de apoio e serviço do CEASM. As 
decisões são tomadas na esfera central da ONG, ficando para o grupo que coordena a biblioteca, a responsabilidade pela condução da rotina de trabalho.

Os projetos em que pudemos identificar maior participação da comunidade são aqueles que são criados e/ou coordenados por lideranças locais, que trabalham no sentido de resgatar e defender a cultura local, numa crescente valorização do sentimento de comunidade. São eles:

\begin{tabular}{|l|c|c|c|}
\hline \multicolumn{1}{|c|}{ BIBLIOTECA } & UF & CIDADE & BAIRRO/REGIÃO \\
\hline BVL de Macapá & AP & Macapá & Corre Água do Piririm \\
\hline BC Maria das Neves Prado & BA & Nova Soure & São José do Paiaiá \\
\hline $\begin{array}{l}\text { BVL da Comunidade Santa } \\
\text { Tereza }\end{array}$ & MA & Mirinzal & Quilombo Santa Tereza \\
\hline BC de Poços de Caldas & MG & $\begin{array}{c}\text { Poços de } \\
\text { Caldas }\end{array}$ & Zona rural \\
\hline BVL da Comunidade Bengui & PA & Belém & Benguí \\
\hline $\begin{array}{l}\text { BVL da Comunidade de } \\
\text { Caracaraí }\end{array}$ & RR & Caracaraí & Vista Alegre \\
\hline $\begin{array}{l}\text { BVL da Comunidade Boca da } \\
\text { Mata }\end{array}$ & RR & Pacaraima & Boca da Mata \\
\hline $\begin{array}{l}\text { BVL da Comunidade Santa } \\
\text { Rosa }\end{array}$ & RR & Pacaraima & Santa Rosa \\
\hline BC Zumaluma & SP & Embu das Artes & Favela do Inferninho \\
\hline BC Prof. Waldir de Souza Lima & SP & Itu & Centro \\
\hline BC Casulo & SP & São Paulo & Parque Real \\
\hline BC Ler é Preciso da Coopamare & SP & São Paulo & Pinheiros \\
\hline BC Livro-Pra-Quê-Te-Quero & SP & São Paulo & Parque Bristol, Jardim São Savério, Vila \\
\hline BC Solano Trindade & SP & São Paulo & Cidade Tiradentes \\
\hline
\end{tabular}

Quadro 5 - Relação de experiências com maior nível de participação.

Fonte: 0 autor (2008)

Dentre o grupo, a Biblioteca Comunitária Maria das Neves é uma experiência que se coloca aberta à participação da comunidade no processo decisório. Para isso, lança mão do Conselho de Biblioteca, como o espaço de participação. Formado por pessoas eleitas pela comunidade, é no conselho que são tomadas as decisões sobre o dia-a-dia e o futuro da biblioteca. Geraldo Prado, idealizador do projeto, diz que o processo participativo naquela comunidade não é uma prática comum. Lembra que aquela é uma região marcada pelo coronelismo e que a comunidade tem muita dificuldade para assumir o papel de protagonista na história. Mas, por meio de um trabalho que considera pedagógico e de conscientização, acredita que estão avançando muito nesse processo. 
Para nós, quanto mais forte o sentimento de comunidade mais natural e intenso são os processos participativos. Esta característica pode ser identificada com clareza na fala dos entrevistados responsáveis pelas bibliotecas Vaga Lume, na região amazônica. A cultura indígena e a cultura das comunidades de remanescentes quilombolas com suas históricas lutas pela preservação de suas terras e do meio ambiente, somadas às relações de troca e parentesco estabelecidas há séculos, garantem a prática participativa nesses projetos. É natural a criação de conselhos formados por membros da comunidade para participar das decisões da biblioteca e definir os caminhos que seguirá.

É importante esclarecer que a Associação Vaga Lume restringiu seu trabalho às comunidades com população de 10 a 500 famílias da zona rural: ribeirinhas, quilombolas, indígenas, assentamentos rurais, em reservas extrativistas ou em beiras de estradas. E, ao identificar as características dos povos da Amazônia, a coordenadoria do Programa teve a sensibilidade para respeitar suas dinâmicas e incorporá-las ao projeto, oferecendo à comunidade a oportunidade de aprimorar seus próprios mecanismos de organização.

Hoje, faz parte do processo de seleção de uma nova comunidade para implementação de uma biblioteca Vaga Lume o reconhecimento da mesma, como grupo. Um exercício que é feito em reuniões em que participam os membros da comunidade, lideranças locais, multiplicadores e coordenadores do Programa. Em alguns casos as discussões são calorosas, pois algumas pessoas entendem a igreja como uma comunidade e, como alguns povoados possuem mais do que uma igreja, fica a dúvida, afinal será uma biblioteca comunitária de todos os membros do povoado ou uma biblioteca da comunidade da igreja $\mathrm{x}$ ou $\mathrm{y}$ ?

Uma estratégia utilizada pela Associação Vaga Lume para colaborar com o grupo nesse processo é a realização de um teste para identificar o nível de interesse da comunidade pela biblioteca e sua organização comunitária. Esse "teste", na realidade um questionário, age como um instrumento para a realização do diagnóstico inicial. Por meio dele é possível identificar praticas participativas do tipo: mutirão, reuniões para tomada de decisões coletivas, rádios e jornais comunitários, associações, grupos liderados por jovens ou mulheres, assim como a disposição pelo trabalho voluntário e as relações com os agentes externos, seja o poder público, seja as organizações locais. (ANEXO C). 
A Biblioteca Vaga Lume da Comunidade da Boca da Mata ${ }^{20}$, por exemplo, constituiu o Conselho Bibliotecário, composto pelo coordenador da biblioteca, Luiz Madeiro, multiplicador e mediador de leitura, por jovens voluntários e professores da Universidade Estadual de Roraima. As reuniões são mensais e a partir delas são estabelecidos os cronogramas e planos de trabalho diário na biblioteca.

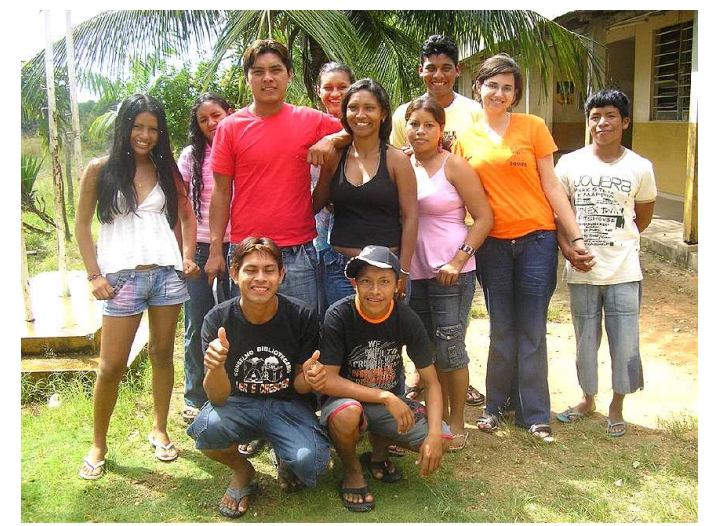

Figura 14 - Conselho Bibliotecário da BVL da Comunidade de Boca da Mata

Fonte: Acervo Associação Vaga Lume

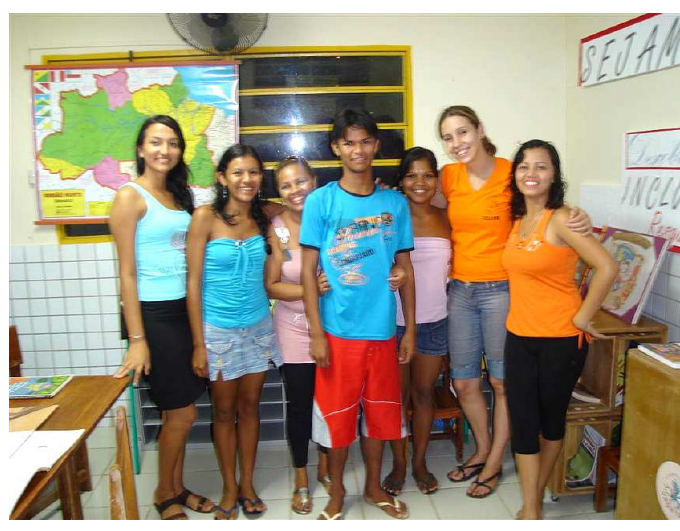

Figura 15 - Grupo de voluntários da BVL da Comunidade de Corre Água do Piririm Fonte: Acervo Associação Vaga Lume

Carlos Magno, coordenador da Biblioteca Vaga Lume da Comunidade de Santa Tereza, ressalta em sua entrevista a importância que teve o envolvimento do pessoal da Pastoral da Terra no projeto da biblioteca. As mulheres envolvidas nos trabalhos de saúde ajudam a divulgar a biblioteca, a levar livros para famílias que moram distante e, em alguns casos, aproveitam suas visitas para ler uma história para as crianças. A idéia é unir esforços e potencializar suas práticas sociais.

Cabe esclarecer que as comunidades de remanescentes quilombolas, como é o caso acima, têm um forte sentimento de apropriação em relação à terra, à água, à casa da farinha ${ }^{21}$, e aquelas que tiveram contato com o Projeto Expedição Vaga Lume incorporaram a causa da leitura a esta tradição. Cada comunidade tem seu presidente ou coordenador, que desempenha o papel de líder local e cada membro da comunidade tem suas responsabilidades definidas. É nas reuniões comunitárias que são tomadas as decisões que irão interferir no cotidiano do grupo.

\footnotetext{
${ }^{20}$ A Boca da Mata é uma comunidade indígena dentre as 63 que existem no município de Pacaraima. A Expedição Vaga Lume está trabalhando atualmente na constituição de bibliotecas comunitárias em 4 comunidades indígenas daquela localidade: Boca da Mata, Bananal, Sorocaima II e Santa Rosa.

${ }^{21}$ Galpão destinado à produção de farinha de mandioca, administrado coletivamente.
} 
No caso da biblioteca de Poços de Caldas, em Minas Gerais, o sentimento de comunidade também é facilmente identificado. A comunidade, formada por 150 pessoas, trabalhadores da Fazenda Lambari, encontram nesse projeto a construção de sentido para a sua vida. Onde antes só havia trabalho duro, na terra, hoje, a partir da biblioteca, que se transformou num espaço coletivo, há cultura, educação e lazer para todos. São lavradores, donas de casas, crianças e jovens que transformam suas vidas a partir da leitura e do acesso à informação, ampliando assim suas oportunidades de trabalho.

Eu nunca pensei que pudesse ser mediadora de leitura. E hoje sou educadora da biblioteca e estudante do $3^{\circ}$. ano do ensino médio.

(Hilda Márcia Albino Sebastião, educadora da Biblioteca Comunitária de Poços de Caldas)

Com a idéia de oferecer aos colonos da fazenda um complemento à educação formal, o dono da Fazenda Lambari contratou a consultoria da A Cor da Letra para desenvolver um projeto de leitura na comunidade. Tendo a mediação de leitura como eixo central de sua proposta de trabalho, A Cor da Letra começou atuando na formação de professores da escola rural que atendia àquela comunidade. Cabe esclarecer que as metodologias empregadas por essa consultoria têm como princípio a formação de cidadãos críticos e autônomos e, para isso, prevê em seus planos de ação o estímulo as práticas participativas. A experiência de Poços de Caldas é o resultado desse trabalho. Hoje a fazenda tem um espaço cultural, onde está sediada a biblioteca, que é gerido pela própria comunidade, a qual foi formada para assumir essa tarefa, de maneira que as decisões sobre os rumos do projeto são tomadas pelo grupo. Cabe esclarecer que a A Cor da Letra continua monitorando o projeto e dando suporte pedagógico para a equipe local.

Márcia Wada (2004, p. 44), uma das coordenadoras da A Cor da Letra, afirma que "ouvir histórias lidas pelo mediador cria um clima de descontração, carinho e imaginação que favorece descobertas para as crianças". E acrescenta,

ser mediador é estar disponível para ler o que as crianças desejam, ouvir o que elas falam, observar o grupo e acompanhar seu desenvolvimento, possibilitando que todas participem dos momentos de leitura. Para ser leitor é preciso desejar (WADA, 2004, p. 44). 


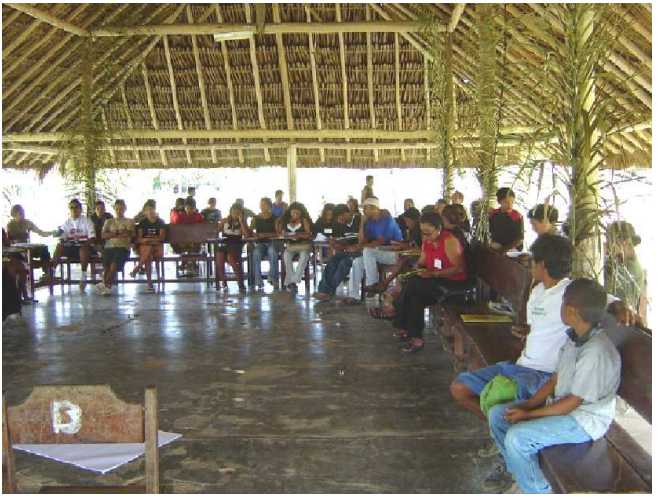

Figura 16 - Formação de mediadores de leitura na Comunidade de Pacaraima Fonte: Acervo Associação Vaga Lume

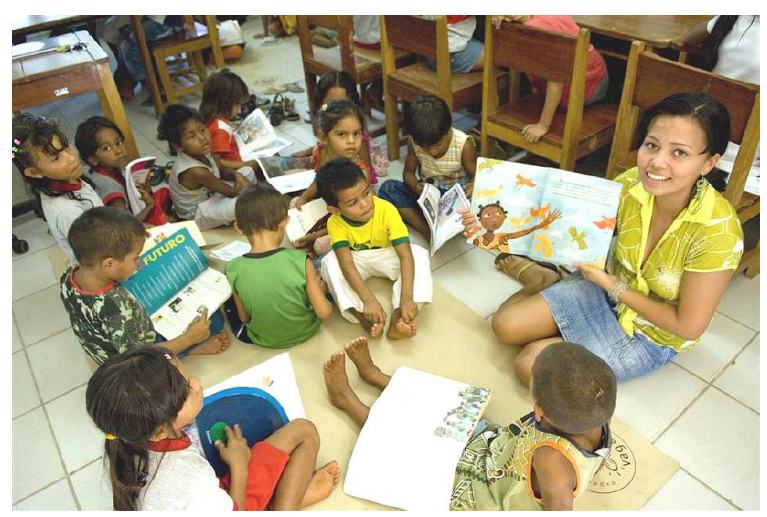

Figura 17 - Mediação de leitura na BVL da Comunidade Corre Água do Piririm

Fonte: Acervo Associação Vaga Lume

É interessante recuperar a pesquisa realizada pelo aluno Rômulo Morishita da ECA/USP, sob a orientação da professora Maria Christina Barbosa de Almeida, a cerca do Projeto Mudando a História na Obra Social da Paróquia São Mateus Apóstolo, coordenado também pela A Cor da Letra. Nessa pesquisa, Morishita (2006) concluiu que as pessoas envolvidas no projeto, formadas na metodologia de mediação de leitura, têm demonstrado uma grande disposição para criar uma biblioteca comunitária.

Os discursos das lideranças das bibliotecas comunitárias localizadas na zona norte do país, assim como das lideranças dos movimentos sociais das periferias das grandes cidades, evidenciam a importância que tem a comunidade em suas vidas e na dinâmica da biblioteca. Nesses casos, o conceito apresentado por Marilena Chaui (1999) se enquadra perfeitamente: a comunidade para eles é formada por aquele grupo de pessoas que se conhece pelo nome, tem contato cotidiano e tem objetivos comuns. Termos como "nossa casa", "nossa família", "nossas crianças" são recorrentes.

A forma de registro de usuários pode ser considerada uma evidência da noção de comunidade, visto que mostra uma atitude de respeito e solidariedade para com seus membros. Na falta de endereço para o empréstimo de um livro, a biblioteca da Coopamare utiliza as informações possíveis, tal como: "Zezinho, amigo do João borracheiro da esquina".

Das experiências em zonas urbanas, as que se destacam com maior participação são as bibliotecas: Casulo, Ler é Preciso Coopamare, Livro-Pra-QuêTe-Quero, Solano Trindade, Zumaluma e Prof. Waldir de Souza Lima. 
A experiência de criação da Biblioteca Comunitária Casulo é marcada pela participação da comunidade. As lideranças jovens locais foram estimuladas e formadas para agir de forma participativa. Como relatado na seção anterior, foram elas que definiram como deveria ser aquela biblioteca e hoje são esses mesmos jovens que coordenam o espaço. De maneira organizada, estão sempre envolvendo novos atores, como, por exemplo, os bolsistas do Projeto de Formação de Jovens Professores. Os jovens bolsistas ganham $50 \%$ de desconto no curso superior de Educação, oferecido pelo Instituto Superior de Educação de São Paulo Singularidades e, em contrapartida, atuam na biblioteca. Participam das reuniões regulares onde são tomadas as decisões que vão gerar o cronograma periódico de atividades da biblioteca. Nesse caso, o grupo não participa da tomada de decisão das questões que envolvem os recursos e parcerias, estas questões ficam na esfera do ICE.

As experiências que mais se assemelham à do Casulo são as de Heliópolis e a da Maré, por terem uma instituição mantenedora para apoiá-las. Em relação a esta característica, pudemos perceber que quanto mais democrática for a instituição mantenedora, mais democrática é a gestão da biblioteca. A participação vai depender das formas de entendimento e condução dos processos pelas entidades às quais estão vinculadas.

Diferentemente do Casulo, a biblioteca da Coopamare é liderada por adultos. A experiência de quase 20 anos de vida cooperada fez com que os integrantes da Coopamare assimilassem a prática da participação e levassem essa forma de atuação para a gestão da biblioteca. Apesar de todas as dificuldades, vulnerabilidade, heterogeneidade, inconstância de seus membros, tendo em vista sua situação econômica e social, a biblioteca possui um conselho ativo, que se reúne quinzenalmente, formado por moradores de rua, albergados, carroceiros, membros do Instituto Ecofuturo, moradores do bairro e representantes da Subprefeitura de Pinheiros. 

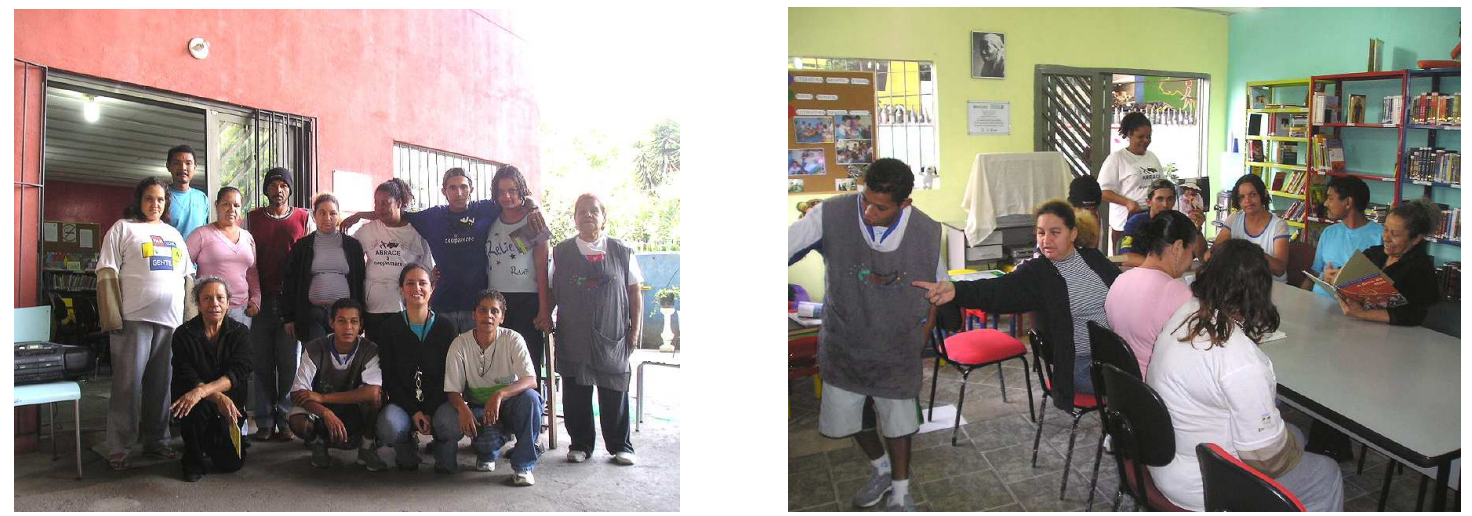

Figura 18-19 - Biblioteca Comunitária Ler é Preciso da Coopamare Fonte: o autor (2008)

Já no caso das bibliotecas Livro-Pra-Quê-Te-Quero e Solano Trindade, é em função do forte trabalho de conscientização que os membros dos movimentos Posse Poder e Revolução e Força Ativa estão envolvido, que torna a gestão dessas bibliotecas referência no processo participativo. Esses jovens têm experiência de participação em varias esferas, como, por exemplo, no Conselho Tutelar e Orçamento Participativo. Assim como na Coopamare, todas as decisões são tomadas em grupo. Por meio de comissões, são organizadas assembléias onde são deliberadas as ações que deverão ser executadas num determinado período e as pessoas que ficarão responsáveis pela sua execução. Não há uma estrutura formalizada, há uma divisão de tarefas.

Pudemos perceber que o grupo de jovens da Zumaluma também tem uma forte consciência da importância da participação nas tomadas de decisões sobre a viabilidade, a efetivação e o desenvolvimento das ações da biblioteca. É durante o trabalho e em reuniões com os integrantes da Associação que são discutidos os caminhos do projeto. A comunidade, por sua vez, é estimulada a participar da maneira que pode, colocando suas habilidades a favor do projeto. Na qualidade de pedreiros, marceneiros ou pintores colaboram na manutenção da casa, na qualidade de professores colaboram na formação de jovens com cursos de informática, capoeira ou línguas.

Diferentemente, em Itu, na Biblioteca Comunitária Prof. Waldir de Souza Lima, os jovens criaram uma estrutura organizacional que segue o modelo de associação. Essa estrutura é formada por uma diretoria, com presidente, secretários, tesoureiros, conselho fiscal e conselho deliberativo. No conselho deliberativo, aprovaram um estatuto e as normas internas de funcionamento da biblioteca. Percebemos por meio 
dessa estrutura a determinação do grupo em se organizar no sentido de caminhar em direção à criação de uma organização formal para apoiar o projeto.

As experiências analisadas no contexto urbano das grandes cidades, que possuem maior grau de participação, confirmam que o sentimento de pertencimento à comunidade é natural e valorizado por seus grupos, conforme apontado por Almeida e Machado (2006), no relato "Bibliotecas comunitárias em pauta". Esse sentimento em relação ao local revela que nos tempos de pós-modernidade é a favela, a vila ou ainda o bairro, o espaço mais importante nas grandes cidades. Beatriz Sarlo (2004, p.14) observa que hoje as pessoas "pertencem mais aos bairros urbanos (e aos 'bairros audiovisuais') do que nos anos 20, quando a ida ao 'centro' prometia um horizonte de desejos e perigos [...]."

Duas grandes preocupações foram apontadas pelos jovens lideres das experiências nas favelas no que diz respeito à perda do foco inicial do projeto em função do processo participativo. Eles tratam esta questão como um perigo e se organizam para que isso não aconteça. Entendemos que esse comportamento reflete a noção de ecologia da ação apontada por Edgar Morin (2002), ou seja, reflete a complexidade que envolve as escolhas e decisões, assim como riscos e incertezas.

Uma preocupação está na necessidade desses espaços e de suas atividades possibilitarem a interação com os diversos grupos locais, de maneira que esses grupos se apoderem da biblioteca como um espaço seu. Na favela, é comum existirem vários movimentos de jovens, por exemplo: aqueles ligados à música, como o pessoal do samba, pagode, rap, hip hop ou funk, outros ligados a arte de rua, como os grafiteiros, assim como o pessoal da capoeira, ou ainda, do grupo ligado à literatura e à poesia. A cultura, com toda sua diversidade, dinamicidade e pluralidade gera a necessidade de administrar as diferenças entre os desejos e saberes dos diferentes grupos sem que se perca a intenção inicial do projeto biblioteca. Para nós é esse um dos grandes fatores que levam esses espaços a lançar mão da ação cultural como foco de suas atividades.

Outra grande preocupação desses mesmos jovens está na necessidade de articulação e no estabelecimento de parcerias que garantam sua sustentabilidade, sem, no entanto, desvirtuar o foco principal da biblioteca. Eles estão atentos para o uso indevido de seus nomes e de suas comunidades e questionam as formas como essas parcerias vêm sendo propostas. Além disso, têm consciência que a parceria 
trará uma burocratização para um ambiente que tem uma proposta oposta e nem sempre está preparado para enfrentar esta nova tarefa.

Esta percepção, postura e atitude do grupo nos fez perceber a questão da problematização discursiva apontada por Habermas (apud FREITAG; ROUANET, 1980). Foi no discurso das lideranças jovens, indígenas e de remanescentes quilombolas que identificamos menor incidência de obstrução da comunicação. Esse fato os coloca numa posição privilegiada em relação à ação participativa e ao mesmo tempo, nos mostra a grande diferença discursiva entre eles e as lideranças das bibliotecas Criança Esperança, Paulo Coelho, Ler é Preciso de Taquari, ou de Magé, assim como das bibliotecas Cultura Jovem e Emmanuel.

\subsubsection{As diferentes formas de articulação e sustentabilidade}

A participação individual e coletiva gera as articulações locais e são estas que garantem a sustentabilidade desses projetos, visto que a maioria deles não conta com recursos para aquisição de acervo, equipamentos e materiais de apoio, manutenção do espaço, ou, ainda, para o pagamento do pessoal envolvido na ação. Como já vimos anteriormente, não há políticas públicas que apóiem estas ações, no entanto, em alguns casos, é a partir das articulações com as prefeituras, as universidades, por meio de seus programas de extensão, ou ainda com uma empresa ou fundação vinculada a uma empresa que se estabelece algum tipo de apoio.

O primeiro exemplo de articulação que apresentamos refere-se à experiência de Poços de Caldas. O dono da Fazenda Lambari, Raymond Rebetez, idealizador daquela biblioteca, articulou uma parceria com o Grupo Astra Café, do qual faz parte, e a empresa norueguesa Kaffehuset Friele, a qual compra o café produzido pelo Grupo. Foi essa parceria que viabilizou a construção do Centro Educacional e Cultural Kaffehuset Friele, que abriga a biblioteca e garantiu assim a sustentabilidade do projeto. Nesse caso, o protagonista lançou mão do conjunto de relações que possui para viabilizar uma ação local. 

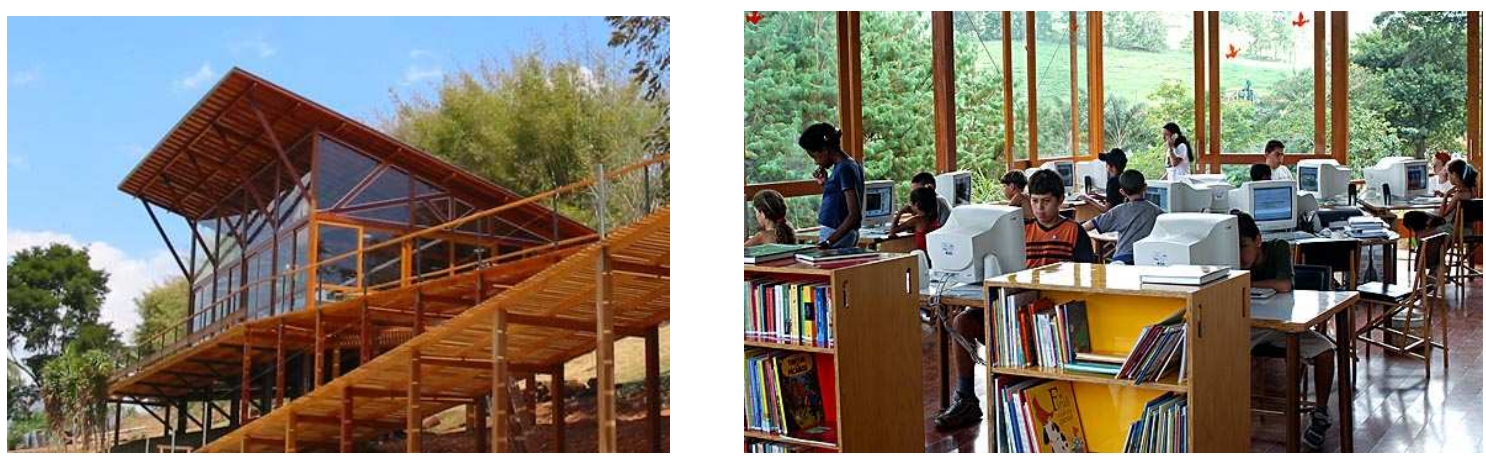

Figura 20-21 - Centro Educacional e Cultural Kaffehuset Friele

Fonte: sítio da Astro Café (www.astrocafe.com.br/acoes.asp?IDConteudo=10\&language=pt\#)

Ao longo da pesquisa, pudemos perceber que a capacidade de ação de um movimento é bem diferente da capacidade de ação e articulação de uma organização da sociedade civil e, por sua vez, da de uma empresa. Ou seja, há grandes diferenças entre as ações e articulações desencadeadas pelo Instituto Ecofuturo e pelo Instituto de Cidadania Empresarial, ambos vinculados a empresas, das desencadeadas pela Associação Vaga Lume, ou ainda pelas ONGs Educa São Paulo e Associação Maria das Neves Prado.

Tanto a Associação Vaga Lume, como o Instituto Ecofuturo se responsabilizam, inicialmente, pelas articulações locais. Os primeiros contatos com a comunidade são feitos por meio dos órgãos governamentais, em sua maioria Secretarias Municipais de Educação. Em seus planos de ação, as duas organizações prevêem o fomento das articulações por meio de reuniões com as lideranças locais, representantes das associações de moradores, associações de professores, entre outras. A continuidade desse trabalho fica a cargo dos responsáveis pela biblioteca, ou seja, depende do grupo a ampliação e o fortalecimentos das articulações locais.

A manutenção e continuidade das ações dos Programas Expedição Vaga Lume e Ler é Preciso é viabilizada por meio da aprovação de seus programas na Lei de Incentivo à Cultura do Ministério da Cultura, o que Ihes possibilita a obtenção de patrocínio.

O Programa Ler é Preciso tem como diretriz o estabelecimento de uma parceira com uma empresa local para viabilizar financeiramente o projeto e, com a prefeitura, estabelece um acordo de contrapartida, ficando a cargo da administração municipal as despesas mensais para manutenção do prédio e dos serviços, assim como a remuneração de 2 funcionários. 
Vale salientar que tanto a Associação Expedição Vaga Lume como o Programa Ler é Preciso, ao iniciar o processo de articulação local, alertam a comunidade para a necessidade de se constituírem legalmente para estabelecer suas próprias parcerias. Com o intuito de preparar os grupos para dar continuidade a seus projetos de maneira autônoma, o Programa Ler é Preciso incorporou a seus conteúdos a oficina de gestão e sustentabilidade, que contempla a elaboração de um plano de captação de recursos e o fortalecimento do conselho gestor da biblioteca.

A Biblioteca Comunitária Paulo Freire, da Maré, é um exemplo de articulação com o meio acadêmico, visto que a parceria estabelecida junto à Escola de Biblioteconomia da UNIRIO desencadeou um processo de qualificação dos serviços oferecidos por ela. Hoje a biblioteca cumpre de maneira exemplar o papel da biblioteca pública ausente na região. Para se ter uma idéia, a biblioteca conta com todo o seu acervo processado e disponibiliza para a consulta local um catálogo informatizado; além disso, abre todos os dias da semana, inclusive sábado e domingo, no horário das $9 \mathrm{~h}$ às $22 \mathrm{hs}$. Esta disposição amplia a possibilidade de uso de seu acervo e dos serviços que oferece e respeita as necessidades específicas daquela comunidade. Cabe ressaltar que esta é a única experiência, do universo das 29 analisadas, que conta com o apoio de uma Escola de Biblioteconomia.

A Biblioteca Comunitária de Heliópolis, por meio da UNAS, estabeleceu uma parceria com o Banco Panamericano desde o início da sua criação e, hoje, o banco é responsável pelos recursos para a manutenção do prédio e pagamento dos monitores, jovens da comunidade, gestores da biblioteca. Cabe esclarecer que o Banco Panamericano tem uma agência dentro da favela e que o arquiteto Rui Ohtake colaborou inicialmente da mesma forma que o fazendeiro de Poços de Caldas, ou seja, colocando suas relações de poder a favor do projeto. 

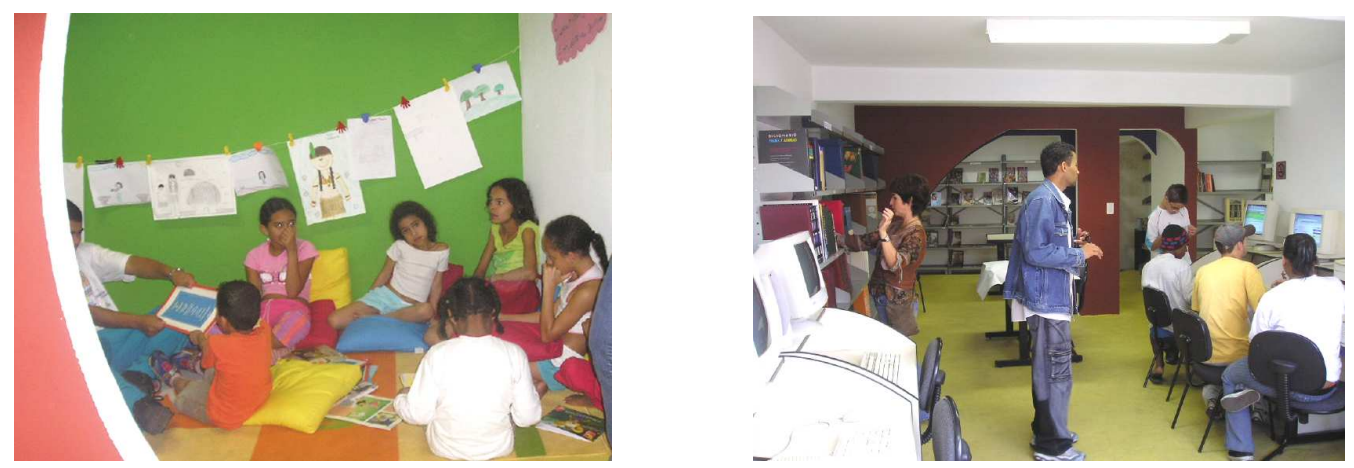

Figura 22-23 - Biblioteca Comunitária de Heliópolis (setembro de 2005) Fonte: 0 autor (2005)

Assim como no caso do Casulo, as parcerias e os recursos das bibliotecas da Maré e de Heliópolis são administrados pela CEASM e pela UNAS, respectivamente. Essas bibliotecas acabam como parte de uma estrutura organizacional maior e seguem a política e os princípios da instituição.

É importante destacar a preocupação e as dificuldades com a avaliação apontada por Márcia Licá, monitora da Biblioteca Comunitária do Projeto Casulo. Os resultados do trabalho da biblioteca, diferentemente de outros projetos do Casulo, são difíceis de serem mensurados, tendo em vista a subjetividade que permeia todas as ações. Em função da necessidade de comprovar mudanças para garantir recursos, os jovens começaram a estudar essa questão e estabeleceram os indicadores abaixo relacionados para fins de medição:

$\checkmark$ Número de filhos que trazem os pais para a biblioteca;

$\checkmark$ Relatos de leitura dentro e fora da biblioteca;

$\checkmark$ Relatos de mudança de comportamento de pessoas que freqüentam a biblioteca;

$\checkmark$ Número de mediação de leituras realizadas;

$\checkmark$ Multiplicação de mediadores de leitura na comunidade;

$\checkmark$ Crescimento pessoal do próprio grupo envolvido no trabalho da biblioteca.

O fato das bibliotecas contarem com membros da comunidade na constituição da equipe de trabalho é determinante para fomentar as articulações locais. Esse é um motivo que leva as experiências que não contemplam a participação direta de membros da comunidade na sua gestão a distanciar-se do conceito de biblioteca comunitária. Consideramos exemplo disso a experiência do Espaço Criança 
Esperança, na cidade do Rio de Janeiro. Cabe esclarecer que isto não significa que projetos como este não se articulem, pelo contrário, possuem uma vasta "carteira" de patrocinadores externos à comunidade atuando na linha da filantropia empresarial.

Outra questão presente nessa esfera é que as bibliotecas que surgem de uma ação individual, ou de um movimento social, ao buscar parceiros e apoiadores esbarram no fator legal, diferentemente daquelas que já nascem vinculadas ou são incorporadas por uma organização. É nesse momento que percebem que precisam se constituir como uma pessoa jurídica, com número no Cadastro Nacional de Pessoa Jurídica (CNPJ). Exemplos disso são as organizações abaixo relacionadas, todas criadas com esse fim:

$\checkmark$ ONG Educa São Paulo;

$\checkmark$ Associação Centro Cultural Biblioteca Comunitária Tobias Barreto;

$\checkmark$ Associação Maria das Neves Prado;

$\checkmark$ ONG Projetos Culturais T-Bone;

$\checkmark$ Associação Biblioteca Zumaluma;

$\checkmark$ Associação Amigos da Biblioteca Solidária.

Ao constituir-se como associação ou organização da sociedade civil de interesse público (OSCIP), passam a ser regidas por estatutos que prevêem uma estrutura organizacional composta por diretorias e/ou conselhos eleitos pelo grupo. Esses canais podem servir como espaços de participação para a comunidade e estimular esse processo. No entanto, podem também ser apenas simulacros de participação, quando vistos como mera formalidade para cumprimento legal.

Individualmente, as "novas" organizações que se constituem são levadas a trabalhar a busca de recursos para a sustentabilidade de seus projetos.

Devanir Amâncio, por meio da ONG Educa São Paulo, estabeleceu uma parceria com uma empresa de limpeza urbana da cidade, para criar a Biblioteca Comunitária dos Garis. Posteriormente, uma nova parceria com Pontifícia Universidade de São Paulo (PUC-SP) garantiu aos garis e lixeiros, que trabalham no entorno da praça em que estão localizados, cursos de alfabetização ministrados por alunos e professores universitários. 
Avesso à participação, Evandro da Silva descarta essa possibilidade na Biblioteca Comunitária Tobias Barreto. Quanto ao conselho constituído na formação da Associação, ficou claro em seu discurso que o mesmo só existe para cumprir a formalidade exigida pelas parcerias que vem estabelecendo. Foi dessa forma que conseguiu o financiamento do Banco Nacional de Desenvolvimento Econômico e Social (BNDES), no valor de $\mathrm{R} \$ 651,000.00$, para a construção de um prédio para a Associação Centro Cultural Biblioteca Tobias Barreto. Nesse caso, é interessante observar como a mídia interfere nas relações, visto que a Biblioteca Comunitária Tobias Barreto é conhecida no país pela repercussão jornalística que teve e, segundo o próprio Evandro, foi a ampla divulgação da sua proposta nos grandes jornais e na internet que garantiu o sucesso de suas parcerias. (BNDES, 2005; VIANNA, 2006)

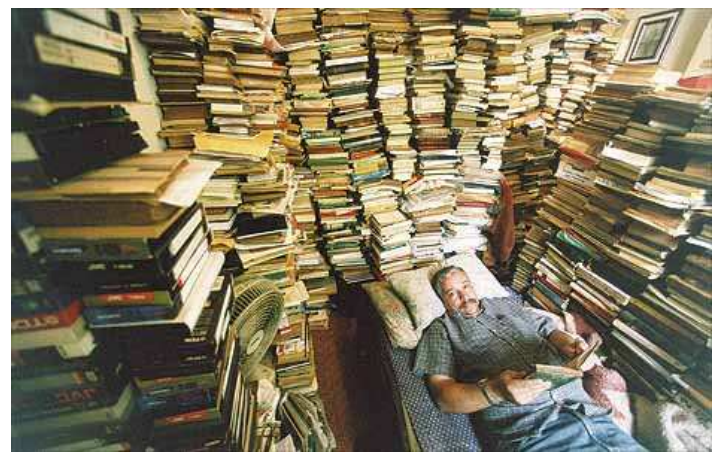

Figura 24 - Evandro, no quarto em que dorme em sua casa-biblioteca.

Fonte: Jefferson Coppola/Folha Imagem

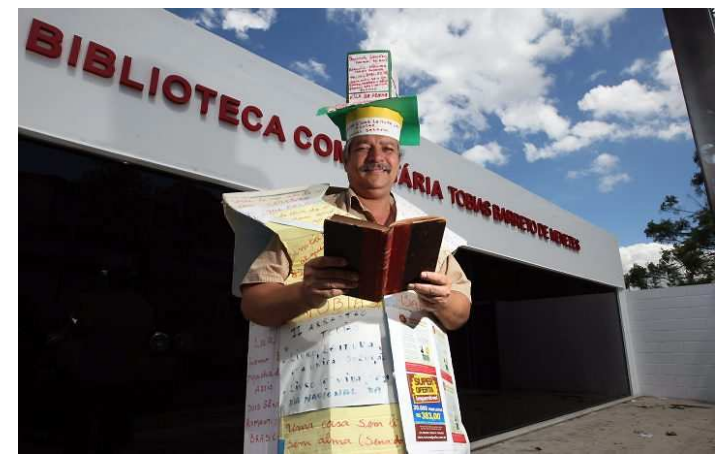

Figura 25 - Evandro vestido de homem-livro Fonte: Foto: Luis Alvarenga/Extra

Diferentemente, como já abordado anteriormente, a Biblioteca Comunitária Maria das Neves é regida pelo grupo que compõe a diretoria da OSCIP, formada por membros da comunidade. Juntos definiram uma contribuição mínima mensal, no valor de $\mathrm{R} \$ 1,00$, para cada membro da Associação Maria das Neves Prado, o que garante a sustentabilidade básica da biblioteca. É este recurso que gera orçamento para custear as despesas com água, luz e material de apoio às atividades. Além disso, a Associação vem pleiteando recursos complementares por meio do estabelecimento de parcerias com a prefeitura, com o governo federal, assim como com instituições financeiras e organizações da sociedade civil em geral. Por meio de uma parceria com o Serviço Federal de Processamento de Dados da Bahia (SERPRO/BA), conseguiu instalar uma bancada para computadores e com o Banco 
do Nordeste a doação de um computador. Com o Ministério do Meio Ambiente (MMA) criou a sala verde "Fulô de Mandacaru" destinada a atividades de divulgação de documentos sobre meio ambiente, produzidos e/ou fornecidos pelo Ministério. E, com o Instituto HSBC, obteve recursos para viabilizar cursos de aperfeiçoamento para professores da rede pública. Uma negociação em curso está sendo feita com o Ministério da Cultura, para que a biblioteca seja contemplada com um Ponto de Cultura.
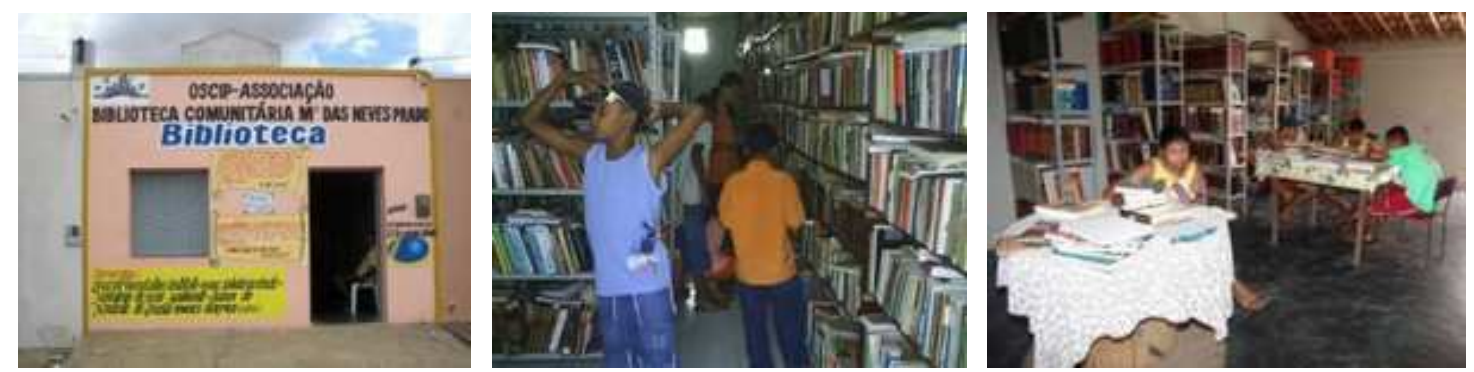

Figura 26-28 - Biblioteca Comunitária Maria das Neves Prado

Fonte: sítio da biblioteca (www.geocities.com/mnpbiblio/pg_1.swf)

Foi por meio da ONG Projetos Culturais T-Bone, de Brasília, que a Biblioteca Comunitária T-Bone conseguiu o patrocínio da Embaixada da Espanha para estender suas ações até os pontos de ônibus da cidade, implantando as chamadas Paradas Culturais. Além da parceria com a Embaixada, o projeto conta também com a parceria do Instituto C\&A e da Companhia de Saneamento Ambiental do Distrito Federal (CAESB), os quais contribuem para o desenvolvimento de ações culturais na biblioteca.
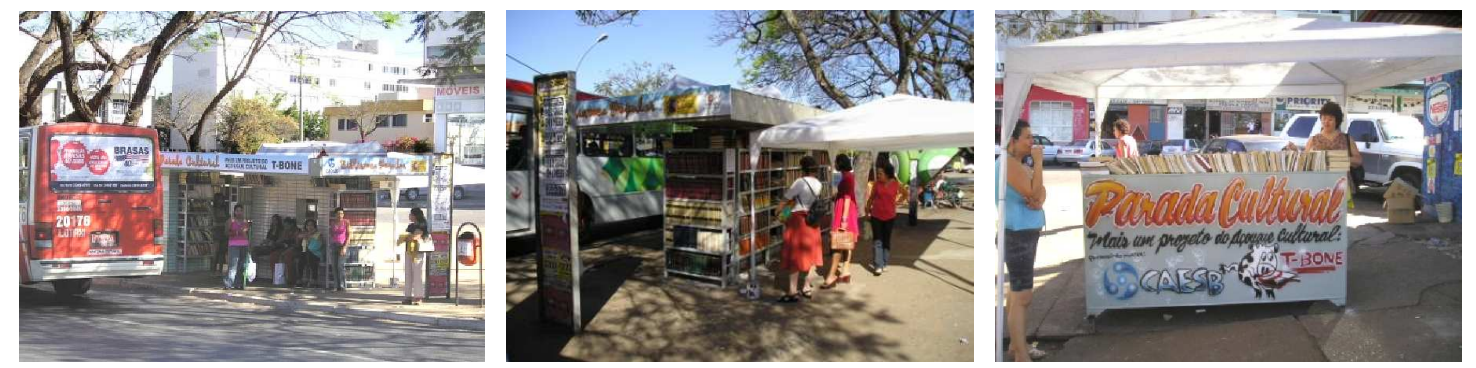

Figura 29-31 - Parada Cultural T-Bone Fonte: o autor (2007)

Segundo Bisturi, se a polícia foi o primeiro problema a ser enfrentado pelo grupo, o segundo problema foi a burocracia gerada pela criação da Associação Biblioteca Zumaluma. Foi por meio da Associação que o grupo conseguiu a parceria 
com a Prefeitura da cidade de Embu das Artes e teve seu apogeu. No entanto, um de seus idealizadores afirma que o grupo de jovens não estava preparado para assumir as responsabilidades demandadas por esta relação e após uma série de problemas decorrentes do não cumprimento de prazos e prestação de contas a parceria foi encerrada. Sinval Pereira dos Santos, um dos responsáveis pelo movimento de criação da biblioteca, acrescenta ainda que a doação de computadores feita pelo Banco do Brasil também não ajudou muito. Afinal, eram computadores velhos, com problemas, que precisavam de recuperação e manutenção. Como o apoio só previu a doação dos equipamentos, a biblioteca ficou com mais um problema para resolver.

Bisturi explica que a articulação estabelecida pela Zumaluma é baseada numa relação de "vizinhança com a comunidade, oferecendo e recebendo o tempo todo. Trocamos saco de cimento por aulas de informática".

Não podemos nos esquecer que a condição dos jovens envolvidos nesses processos é de sobrevivência. Eles não podem dedicar-se exclusivamente a trabalhos voluntários, precisam conciliar suas atividades na biblioteca com a rotina diária de trabalho ou de busca de emprego, o que leva em alguns casos à dispersão do grupo. Esse quadro levou a Biblioteca Comunitária Zumaluma a diminuir suas atividades e desmobilizar suas lideranças. O projeto que surgiu de uma ação coletiva cheia de sonho, esperança e garra está fragilizado pelas inúmeras dificuldades enfrentadas pelo grupo.

É importante ressaltar que o dilema enfrentado pelas lideranças da Associação Zumaluma é vivido por muitos outros grupos. Kcal Gomes, o "traficante de livros" da comunidade do Bode em Recife expressa isso na letra de uma de suas músicas:

Eu sou apenas mais um brasileiro/dividido entre a escola/o sonho e o emprego [...] Se eu estudar serei um sábio com fome/Se eu trabalhar, mais um cidadão sem nome.

(LINS, 2008)

Diferentemente, a Associação dos Amigos da Biblioteca Solidária foi criada em 2004, possui 55 associados considerados parceiros. São apresentados como parceiros também as empresas e pousadas sediadas na região. Segundo seu 
idealizador, Sidnei Rosa, a General Motors do Brasil e a Petrobrás são parceiras graças à Lei de Incentivo à Cultura de São José dos Campos.

O grupo de jovens de Itu, por sua vez, está se organizando para montar uma associação de amigos da biblioteca e, por enquanto, o mecanismo para arrecadar fundos é a contribuição única de $\mathrm{R} \$ 10,00$ para quem quer emprestar livros. Valor que não é cobrado de idosos, aposentados, alunos e professores de escolas públicas.

Com uma postura diferente e desafiando o sistema estão as bibliotecas LivroPra-Quê-Te-Quero e a Solano Trindade. Os dois grupos que são responsáveis pela gestão desses espaços optaram por não se constituir como uma pessoa jurídica e continuam atuando como um movimento social. Isso não significa que não se articulem e estabeleçam parcerias. Por exemplo, nos dois casos, as bibliotecas ficam sediadas num espaço cedido pelo CDHU. A fórmula para o estabelecimento da parceria com o CDHU veio do apoio do IBEAC, uma ONG que apóia e desenvolve projetos ligados a questões da alfabetização e escolarização, com organizações locais. No caso, os movimentos se comprometem com a manutenção e administração do espaço e, o IBEAC, por sua vez, fica responsável junto ao CDHU pelo cumprimento das exigências legais e burocráticas. Diferentemente do Casulo, da CEASM e da UNAS, o IBEAC não é uma instituição mantenedora e as bibliotecas apoiadas por eles continuam autônomas.

Parte dos recursos para a manutenção da Biblioteca Comunitária Solano Trindade vem da contribuição mensal dos próprios integrantes do grupo. Cada integrante do grupo dá uma contribuição mensal de $R \$ 10,00$ e, além disso, cada trabalho individual realizado por influência do grupo reverte em $10 \%$ para o movimento.

Já a Biblioteca Comunitária Livro-Pra-Quê-Te-Quero convida a comunidade a se associar à biblioteca e pede uma contribuição de $R \$ 1,00$ por mês. Dinha relata que como esse pagamento não é regular e nem sempre suficiente para cobrir os gastos de material do dia-a-dia, "quando precisamos de dinheiro, quem pode dá um pouco mais, tipo $R \$ 10,00$ e assim adianta o pagamento de 10 meses". A biblioteca conseguiu também, por meio do IDEAC, participar do programa "Parceiros em Ação" do Banco Santander e ganhar uma bolsa-auxílio para um dos integrantes do movimento fazer o atendimento na biblioteca. Segundo Dinha, isso tem garantido 
que o espaço fique aberto diariamente, o que não ocorria quando contavam exclusivamente com o trabalho voluntário dos jovens.

É importante esclarecer que os jovens relutam em usar o termo voluntariado por compreenderem que suas ações são resultado de um engajamento na luta contra a exclusão e pela ampliação de acesso à leitura. Não querem que suas ações sejam confundidas com práticas filantrópicas.

Em 2005, as duas bibliotecas foram contempladas com o Prêmio Unicsul de Intervenção Social, oferecido pela Universidade Cruzeiro do Sul, que Ihes garantiu recursos financeiros no valor de $R \$ 10.000,00$, divididos entre as 2 bibliotecas comunitárias e uma terceira do bairro de Sapopemba. E, no mesmo ano, a Biblioteca Comunitária Solano Trindade foi contemplada no Programa VAI da Secretaria Municipal de Cultura de São Paulo. Segundo Weber, o grande diferencial desse programa é o fato de não haver necessidade de o grupo ter uma razão social, basta os currículos individuais e o histórico do grupo.

\subsection{ACERVO, INFRA-ESTRUTURA E AÇÕES}

O caminhão de gás passa com seu som de música clássica e toma conta do ambiente da biblioteca.

Neide Duarte

Apesar deste trabalho não estar focado no espaço, acervo, público e serviços, decidimos acrescentar alguns dados sobre esses aspectos, que puderam ser observados durante a pesquisa, pois acreditamos que eles ajudarão o leitor a formar um quadro mais completo das características das bibliotecas comunitárias.

A Biblioteca Solidária, por ter como idealizador e gestor um bibliotecário, segue todos os parâmetros organizacionais da Biblioteconomia e desempenha todas as funções de uma biblioteca pública no distrito de São Francisco Xavier, assim como a Biblioteca Paulo Freire, na Maré. Em relação aos acervos, as duas bibliotecas contam com acervos, ricos, diversificados, tratados e disponibilizados em catálogos informatizados de acesso local.

Destacamos a seguir alguns aspectos das experiências analisadas que nos chamaram a atenção ou por sua peculiaridade ou pelo impacto causado na comunidade. 
5.4.1 Formação, desenvolvimento e tratamento de acervo

Apesar de suas diferenças, a grande predominância das coleções que compõem esses acervos é de documentos textuais impressos, no suporte papel, adquiridos por meio de doações.

A noção de seleção e de qualidade em oposição à quantidade não existe para algumas das experiências analisadas. Nem sempre os idealizadores desses projetos levam em conta que mais do que quantidade são necessários qualidade e objetividade na constituição de um acervo. Esse fato foi evidenciado nas experiências da Penha, no Rio de Janeiro, e da invasão do Prestes Maia, em São Paulo. Constituídos aleatoriamente, têm como premissa que qualquer documento textual deve ser armazenado, independente das necessidades de seus usuários, das condições físicas do material, ou ainda da sua condição de atualidade.

Como já dissemos anteriormente, para nós um amontoado de livros não cumpre a função de uma biblioteca. Nesse sentido recuperamos o comentário do professor Aziz Ab’Saber ao visitar a Biblioteca Comunitária Prestes Maia:

\begin{abstract}
'A biblioteca é uma iniciativa maravilhosa de um grupo de sem-teto. Fiquei positivamente surpreso com o número de obras para o público infantil', conta o professor. A ocupação tem 315 crianças e 380 adolescentes. 'O problema ali é criar estratégias para incentivar a leitura, principalmente entre os jovens. Apesar da idéia louvável, eles não parecem ter noção de que para se pensar uma biblioteca comunitária há três elementos essenciais: objetivo, acervo e estratégias de estímulo à leitura' (AB'SABER apud CASTRO, 2006).
\end{abstract}

Cabe lembrar que o Prof. Aziz Ab'Saber (2005a; b; c) em função da sua larga experiência no estímulo à criação de bibliotecas comunitárias escreveu 3 textos sobre o assunto com 0 intuito de orientar o desenvolvimento desse tipo de experiência.

A Biblioteca Comunitária Tobias Barreto, tão referendada pela mídia como um exemplo a ser seguido, não passa de um depósito obscuro de livros. O espaço não possui nenhuma prerrogativa que lhe confira as características básicas de uma biblioteca, ou seja, seu acervo não apresenta uma mínima organização com vistas à recuperação, não está disposto de maneira que seja possível o seu acesso e mais, o 
espaço e os materiais não se apresentam em condições mínimas de higiene para o manuseio e uso.

Com exceção das bibliotecas Vaga Lume, que são formadas por pequenos acervos, que vão de 300 a 500 itens, nas outras experiências os números giram em torno de 5.000 itens, sendo que alguns acervos chegam a números superiores a 10.000 itens, como é o caso da Biblioteca Comunitária Maria das Neves, com aproximadamente 50.000 itens.

A Expedição Vaga Lume prevê a doação inicial de 300 itens e o Programa Ler é Preciso 1.000 itens para cada nova biblioteca. Ao longo do tempo as comunidades vão ampliando seu acervo com as doações que recebem sistematicamente. É importante ressaltar que as doações na região norte do país são muito escassas, diferentemente da grande quantidade de doações que são oferecidas nas grandes metrópoles, um fato que indica as diferenças de poder aquisitivo nas diversas regiões brasileiras.

A aquisição por doação é praticamente a única forma de ampliação desses acervos. Nos centros urbanos, diariamente são oferecidos lotes de livros para as bibliotecas, porém, desses lotes, muito pouco pode ser aproveitado. Em sua maioria são obras com informações desatualizadas, enciclopédias antigas, livros didáticos, livros do professor, apostilas de cursinho com seus exercícios preenchidos, ou ainda, obras clássicas da literatura, porém em estado inadequado ao uso: sujos, rasgados, riscados e, em alguns casos, infectados por insetos e roedores. É como se o usuário destas bibliotecas, por serem pobres, não precisassem de livros atraentes para se deliciar numa prazerosa leitura, ou ainda, de informação atualizada para suprir suas necessidades diárias. A beleza, estética, atualidade e qualidade, nesses casos, são aspectos ignorados pelos doadores.

Cabe aqui também um comentário acerca da falta de condições desses grupos para deslocar-se para recolher material doado. As pessoas que doam, em sua maioria residentes em zonas centrais, não têm a dimensão da dificuldade que essas comunidades enfrentam para se locomover nas grandes cidades e em muitos casos, por esse motivo, as doações não são efetivadas.

As bibliotecas Vaga Lume são formadas por uma coleção de livros de primeiras leituras infantis e juvenis. Já quanto ao acervo de todas as outras experiências analisadas, podemos dizer que são compostos por obras de literatura em geral, infanto-juvenil, livros didáticos e paradidáticos, livros de cunho religioso, 
obras gerais, enciclopédias, dicionários e histórias em quadrinho. Periódicos, guias e mapas são materiais pouco encontrados nesses espaços.

Ainda em relação ao conteúdo desses acervos, destacamos as coleções de literatura infanto-juvenil das bibliotecas Vaga Lume, Ler é Preciso, Casulo, Poços de Caldas e Heliópolis, assim como a coleção de histórias em quadrinho de Heliópolis. Essas coleções são resultantes da colaboração de especialistas no processo de seleção das obras.

Já o acervo da biblioteca do Espaço Criança Esperança é basicamente formado pela doação de uma coleção de obras de literatura da Academia Brasileira de Letras. Pudemos perceber que essa é a única biblioteca em que o livro, no suporte papel, não é a maior fonte de informação e pesquisa e sim a internet.

Outro destaque deve ser dado para os acervos das bibliotecas Livro-Pra-QuêTe-Quero e Solano Trindade, ambos formados com o cuidado de privilegiar assuntos de importância para os movimentos aos quais estão vinculados: política e ciências sociais. Tanto para o Força Ativa como para o Poder e Revolução, a biblioteca é o espaço de encontro, estudo e reflexão dos integrantes desses movimentos e isso se reflete no ambiente e no acervo que compõe estas duas bibliotecas. Isso não quer dizer que não sejam considerados também outros assuntos de interesse da coletividade. As duas bibliotecas possuem materiais para atender demandas de todas as faixas etárias. Vale destacar a coleção de vídeos nacionais, cuidadosamente selecionados, da Biblioteca Comunitária Solano Trindade.

Quanto às formas de organização na estante, pudemos verificar que de modo geral eles seguem a idéia clássica da divisão das grandes áreas do conhecimento pautadas nas disciplinas escolares.

Cabe comentar a orientação dada pela Fundação Nacional do Livro InfantoJuvenil (FNLIJ) ao pessoal da Coopamare. Seguindo o padrão do projeto, Joana, a catadora de lixo, que passou pelo curso de Auxiliar de Bibliotecas e hoje é responsável pelo espaço, se esforça para classificar as obras de acordo com o Código de Classificação Decimal de Dewey (CDD), numa versão simplificada. Lembramos que estamos tratando com uma comunidade em que a maioria é analfabeta e vê na biblioteca a possibilidade de mudar essa situação. Acreditamos que, nesse contexto, o uso de sistemas complexos de classificação pode mais inibir do que aproximar. Por exemplo, mesmo a CDD simplificada prevê a separação das obras de literatura inglesa, das obras de literatura americana. Joana é uma mulher 
determinada e muito inteligente, porém não tem referencial cultural para identificar diferenças desse tipo, o que Ihe trás angústia e preocupação com a possibilidade de errar em seu trabalho. Por outro lado, nesse momento, será que faz diferença a origem do texto escolhido? Para nós, esse exemplo evidência a necessidade de adequação do modelo proposto pelo Programa Ler é Preciso.

\subsubsection{Equipamentos e infra-estrutura}

Como já dissemos acima, o livro, no suporte papel, é ainda o meio mais utilizado nesses espaços, visto que, nem todas as bibliotecas possuem computador e, em alguns casos, os mesmos não estão conectados à Internet, ou, ainda, o número de equipamentos é reduzido, dificultando o acesso à informação, ao meio eletrônico.

As bibliotecas Zumaluma e de Heliópolis receberam seus computadores por meio de doação de instituições financeiras. A primeira recebeu 7 computadores do Banco do Brasil e a segunda, 5 computadores do Banco Panamericano. No entanto, os computadores são velhos, não possuem ferramentas e softwares adequados para as necessidades de trabalho e o mais importante, as bibliotecas não têm recursos para contratar um serviço de manutenção para os mesmos. O resultado é que os computadores ficam mais tempo quebrados do que em funcionamento. Assim como no caso da doação de livros, o mesmo acontece em relação à doação de computadores.

$\mathrm{Na}$ linha tecnológica, cabe destaque para o software de edição de vídeo que a Biblioteca Comunitária Maria das Neves adquiriu por meio de doação. Essa ferramenta é uma atração para os jovens da comunidade que estão trabalhando na produção de documentários locais.

As bibliotecas criadas pelo Programa Ler é Preciso recebem, além do acervo, um computador e uma impressora, assim como recursos no valor de $\mathrm{R} \$ 2.000,00$ para aquisição de mobiliário.

Em relação às dificuldades de comunicação, destacamos que muitas dessas bibliotecas não possuem nem mesmo telefone; são os casos das bibliotecas Vaga Lume, da região norte do país, Maria das Neves, na Bahia, Emmanuel, no Rio de 
Janeiro, Cultura Jovem, Livro-pra-Quê-Te-Quero, Solano Trindade e Zumaluma, em São Paulo.

A Biblioteca Comunitária Criança Esperança se diferencia nesse contexto pelo forte apelo tecnológico que impera no ambiente. Seus computadores, conectados à internet, assim como a televisão estão instalados no saguão principal, transformando todo o espaço num ambiente multimídia. O problema nesse caso é o forte estímulo ao acesso às mídias vinculadas pela Rede Globo, idealizadora do projeto.

\subsubsection{Usuários e atendimento}

No tocante aos usuários, de modo geral essas bibliotecas destinam seus esforços para atender às necessidades educacionais e culturais de toda a comunidade, crianças, jovens, adultos e idosos, exatamente como a biblioteca pública.

A Biblioteca Comunitária dos Garis, por estar localizada no centro da cidade de São Paulo, próximo a um dos maiores terminais de ônibus, é a única do grupo pesquisado que trabalhar com o foco na população adulta, formada por garis, lixeiros e carroceiros catadores de lixo que freqüentam ou trabalham na região.

Aqueles que transformaram a biblioteca no seu espaço de luta por uma sociedade melhor, tem uma maneira especial para lidar com a comunidade. Nesses espaços impera o respeito, a solidariedade, o afeto e a colaboração. As bibliotecas comunitárias são marcadas pelo que chamamos aqui de ação afirmativa. $\mathrm{Na}$ Biblioteca Comunitária Livro-Pra-Quê-Te-Quero um dos projetos se chama "PodeLevar". A frase que define a forma de relação da Biblioteca Comunitária de Vista Alegre, já citada anteriormente, também representa claramente essa postura: "Não passe sem entrar; não entre sem olhar; não olhe sem pegar; não saia sem levar."

Weber Lopes, explica como é que o grupo se relaciona com os usuários na Biblioteca Comunitária Solano Trindade, 
Quando as pessoas se cadastram, contamos a história da biblioteca, nossas dificuldades, conscientizando a população sobre o caráter comunitário do equipamento e sobre a importância da contribuição de todos para a manutenção do acervo e do espaço. Procuramos mostrar que os materiais retirados são únicos, e outros usuários também precisam deles. Em geral, não há problemas quanto ao descumprimento dos prazos de entrega nem quanto a não-devolução dos materiais (LOPES, 2003, p. 29).

Mais de uma vez a biblioteca foi citada pelos entrevistados como sendo a sua segunda casa. Na Vila Livieiro, Dinha faz questão de reforçar que a biblioteca fica no lugar mais bonito da comunidade: "a Maloca é cercada por grama e lá as crianças podem se reunir para brincar, jogar bola e empinar pipa". São essas crianças que são convidadas a participar de atividades na biblioteca "pelo que elas gostam."

Se você gosta de Axé, venha aqui com o seu grupo oferecer uma oficina de Axé.

Eu não preciso gostar, mas se você gosta e precisa de um espaço, venha!

Vamos conversar.

(Dinha, Biblioteca Comunitária Livro-Pra-Quê-Te-Quero)

Ainda segundo Dinha, as meninas gostam de dançar e os meninos de cantar. A tarefa do pessoal da biblioteca é colocar na mão deles um poema. "Quando eles percebem estão dançando, cantando e lendo."

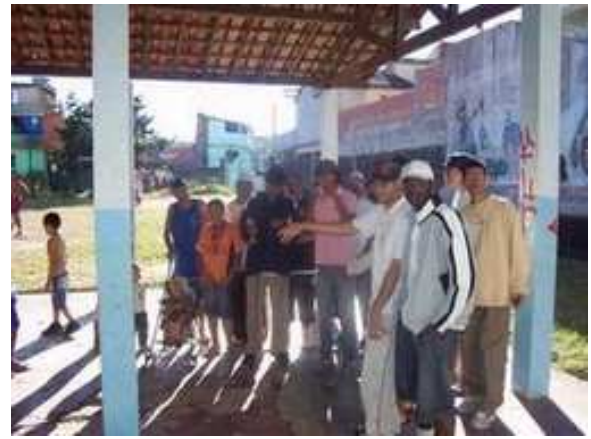

Figura 32 - Maloca Espaço Cultural Fonte: blog da Maloca Cultural ${ }^{22}$

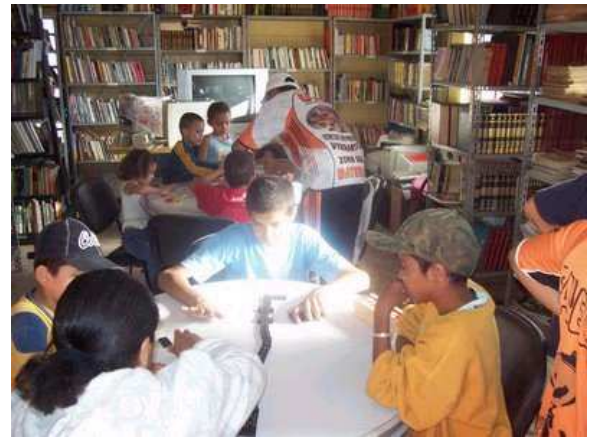

Figura 33 - BC Livro-Pra-Quê-Te-Quero Fonte: blog da Maloca Cultural

A dificuldade em atrair novos leitores, assim como nas bibliotecas públicas, é sentida pelas lideranças desses projetos. Varias pessoas entrevistadas mencionaram a baixa escolaridade e o alto índice de analfabetismo na comunidade

\footnotetext{
${ }^{22}$ Endereço eletrônico: http://malocapraquetequero.blogspot.com/2007/08/maloca-e-suas-estrias.html
} 
como um fator inibidor para ampliar o uso da biblioteca. Esse é um grande problema para as lideranças, pois nem todas conseguem desenvolver estratégias para enfrentá-lo.

A forma encontrada pela Biblioteca dos Garis de estimular a leitura foi por meio dos cursos de alfabetização, já mencionados acima. Já aquelas bibliotecas que contam com jovens rappers em seus grupos, lançam mão da rima e da música para atrair novos usuários. O pessoal do Força Ativa de Cidade Tiradentes, assim como o pessoal da Zumaluma, começa esse trabalho nas escolas da região. Organizam palestras que terminam sempre com um rap que valoriza a leitura e o acesso à informação. Em Heliópolis, veiculava na radio comunitária a seguinte musica feita por um dos monitores da biblioteca:

Heliópolis agora tem uma biblioteca

Ela é comunitária, para todos é aberta

Tem um acervo muito bom, com um objetivo

Pra você ter uma noção, tem cerca de uns 3 mil livros

Se você é um daqueles que não quer acreditar

Pode vir comparecer

Garanto que vai gostar

Termino por aqui, com todo o respeito

Venha para a biblioteca adquirir conhecimento

(Augusto, monitor da biblioteca e morador de Heliópolis)

As necessidades informacionais são imensas e claramente identificadas pelas lideranças jovens entrevistadas. Com essa preocupação o Força Ativa gravou um CD intitulado "Rimar para a prevenção" com 17 musicas que discutem sexo, drogas, AIDS, machismo, racismo, valorização da mulher, entre outros temas que envolvem o cotidiano de crianças, jovens e adultos da periferia. É um exemplo de transmissão de informação pública. No anexo $\mathrm{D}$, recortamos trechos de algumas músicas.

\subsubsection{Equipe interna e formação}

As bibliotecas Vaga Lume, Casulo e de Poços de Caldas diferenciam-se das demais pelo forte trabalho de mediação de leitura que é feito pelos integrantes dos projetos. Duas experiências, a Biblioteca Comunitária Casulo e a de Poços de Caldas têm uma equipe de monitores formada por jovens da comunidade altamente 
capacitados para trabalhar na rotina de atendimento e desenvolvimento de atividades para os usuários.

O Programa Ler é Preciso também prevê a formação dos membros da comunidade que irão atuar nas bibliotecas criadas por eles. Nesse caso é a FNLIJ a instituição responsável por esta formação, sendo que o foco é a organização do acervo e a promoção da leitura por meio dos cursos Promotores de Leitura e Auxiliares de Biblioteca. Os cursos possuem carga horária de 32 horas cada, sendo que o público alvo divide-se em $80 \%$ professores e $20 \%$ membros da comunidade. Apesar de terem feito o curso de promotores de leitura, as pessoas envolvidas nas bibliotecas Ler é Preciso visitadas não desencadearam ações de mediação de leitura nos espaços. Esse fato nos leva a crer que há a necessidade de rever o foco dos cursos oferecidos, seja em relação ao público, seja em relação aos conteúdos, ou ainda, ao monitoramento dos resultados.

Uma demanda do pessoal envolvido na organização dessas bibliotecas refere-se à formação técnica que envolve a seleção e tratamento das coleções com vistas à recuperação da informação. Como já abordado anteriormente, no início eles organizam seus acervos separando pelas grandes áreas do conhecimento de acordo com as disciplinas escolares, porém, conforme o acervo e as demandas dos usuários vão aumentando, começam a aparecer as dificuldades para encontrar a informação desejada ou até mesmo o livro solicitado. Com exceção daquelas bibliotecas citadas inicialmente nesta subseção, que contam com o trabalho de bibliotecários, as demais, não fazem registro bibliográfico e, portanto, não possuem um catálogo para facilitar o acesso e controle do acervo.

Um dos jovens que atua na Biblioteca Comunitária Maria das Neves Prado fez um curso de auxiliar de biblioteca por correspondência e a partir do conhecimento obtido no curso, somado a sua experiência de trabalho na organização dos livros esta formando novos jovens para ajudá-lo nesta tarefa.

Weber Lopes (2003, p.30), integrante do movimento Força Ativa, afirma que obteve o material do curso de "Bibliotecário a Distância", voltado para a formação de gestores de bibliotecas, oferecido pelo Instituto Brasil Leitor e após estudar sozinho, ministrou o curso para vários membros do movimento, formando assim uma equipe de trabalho.

Em muitos depoimentos, os responsáveis pelas bibliotecas declaram que cursos técnicos os ajudariam a atuar melhor na recuperação de informação para a 
comunidade e se colocam abertos para aprender. $\mathrm{O}$ que não querem e deixam bem claro é que "pessoas com ar de soberba venham apontar erros", ou ainda, "se coloquem de maneira impositiva perante o grupo" é o que diz Bisturi da Biblioteca Zumaluma.

\subsubsection{Espaço físico e ambientação}

No tocante ao espaço físico, destacam-se as bibliotecas de Heliópolis e a de Poços de Caldas, as quais contaram com a colaboração de arquitetos para a reforma e construção do espaço. Nos dois projetos foram contemplados espaços diferenciados para os acervos e públicos, nichos de computadores, mesas individuais e em grupo para estudo. Os ambientes são bem iluminados, foram pensados de modo a se constituírem como espaços agradáveis e aconchegantes.

Pouco há para se falar sobre os espaços das outras bibliotecas, visto que estão sediadas em salas ou casas adaptadas, com uma infra-estrutura mínima, adquirida por meio de contribuições locais. Alguns espaços apesar de não serem ideais para acomodar o acervo e as ações desenvolvidas por uma biblioteca, são significativos para a comunidade e representam de maneira objetiva à luta pela transformação local. São os casos das bibliotecas Zumaluma e Livro-Pra-Quê-TeQuero, que ocupam espaços na favela que antes eram usados para o tráfico de droga, violência ou, ainda, prostituição e representavam para aquela comunidade a sua exclusão.

Por meio de mutirões, os grupos reúnem esforços para melhorar o espaço possível. Limpam, pintam e consertam as áreas internas e externas de lugares que antes, não se poderia imaginar transformados num espaço de leitura. Para isso, contam com as habilidades dos próprios membros da comunidade, pedreiros, marceneiros e pintores. E de maneira criativa organizam os espaços para atender às necessidades de armazenamento do acervo e de estudo. Em alguns casos, reservam ainda um pequeno espaço para a administração. 


\subsubsection{Serviços e ação cultural}

De modo geral, as experiências analisadas procuram abrir seus espaços e desenvolver atividades culturais em horário alternativos. A maioria abre nos finais de semana e, sempre que possível, abre também em horários noturnos.

Os serviços oferecidos e as ações desencadeadas por essas bibliotecas que mais vem impactando as comunidades são as mediações de leitura para crianças e jovens e as oficinas voltadas ao interesse específico da comunidade. Podemos dizer que o caráter das iniciativas é cultural e educacional.

A seguir relacionamos algumas das ações desenvolvidas nas bibliotecas analisadas:

$\checkmark$ Curso de aperfeiçoamento para professores - oferecido pela Biblioteca Comunitária Maria das Neves;

$\checkmark$ Seminário de Popularização da Ciência e Tecnologia no Semi-árido Baiano, com enfoque na educação ambiental - oferecido pela Biblioteca Comunitária Maria das Neves;

$\checkmark$ Mediação de leitura, utilizando a metodologia de leitura para o outro, com os livros espalhados pelo chão - atividade permanente nas bibliotecas Vaga Lume, Casulo e de Poços de Caldas;

$\checkmark$ Encontro com escritores, seguido de debate - ação desenvolvida com maior freqüência pelas bibliotecas das zonas urbanas;

$\checkmark$ Roda de histórias e produção de livros artesanais - ação estimulada pela Associação Vaga Lume nas bibliotecas da Amazônia, com o objetivo de resgatar e valorizar a tradição oral, seu passado e seus contadores de história;

$\checkmark$ Concurso de poesia - criado pela Biblioteca Comunitária Tobias Barreto.

$\checkmark$ Apoio e formação de grupos para a constituição de bibliotecas comunitárias - Biblioteca Comunitária Solano Trindade;

$\checkmark$ PodeLevar - Atividade desenvolvida pela Biblioteca Comunitária Livro-PraQuê-Te-Quero, que convida o leitor a fazer uma copia de um trecho de um livro ou um poema, anotar a localização do livro na estante e o endereço da biblioteca e pregar o pedaço de papel em postes, em diversos pontos 
do bairro, convidando outros leitores a conhecer as coleções que compõem a biblioteca;

$\checkmark$ Saraus de leitura - atividades que misturam música e literatura na Biblioteca Comunitária Livro-Pra-Quê-Te-Quero;

$\checkmark$ Seção de vídeo nacional - na Biblioteca Comunitária Solano Trindade

$\checkmark$ Curso de alfabetização, de informática, línguas e de direitos humanos;

$\checkmark$ Oficinas de rima, escrita, leitura, fanzine, artesanato, higiene para meninas, capoeira, grafite, axé, break e samba-rock;

$\checkmark$ Palestras e debates sobre temas de interesse da comunidade. 


\section{BIBLIOTECAS COMUNITÁRAS: DESAFIO PARA AS POLÍTICAS PÚBLICAS}

Uma nova política cultural precisa começar como cultura política nova, cuja viga mestra é a idéia e a prática da participação.

Marilena Chaui

Pensar em políticas públicas para bibliotecas comunitárias é pensar em política também para as bibliotecas públicas e escolares. Se reconhecermos a complexidade que permeia o momento contemporâneo, a relação entre a biblioteca escolar, pública e comunitária é inevitável. Para nós, foi importante isolar a biblioteca comunitária para entendê-la no contexto nacional, porém, não é possível pensar em propostas compartimentadas nessa esfera. Faz-se necessário ampliar o olhar de forma multidimensional, ressaltando fatores considerados relevantes na análise das bibliotecas comunitárias, de maneira a que esses fatores possam contribuir para a construção de uma nova política pública para a área.

Os resultados desta pesquisa demonstram em primeira instância que, conforme já apontado por Barbosa e Machado (2006), "é nos vazios resultantes da omissão do poder público, [que] surgem, cheias de energia, iniciativas" de constituição de espaços de leitura e acesso ao livro, denominados por seus idealizadores como bibliotecas comunitárias, "ligadas ou não a organizações comunitárias, articuladas ou não a outras instâncias, respondendo a uma necessidade percebida por um grupo e alavancada pelo esforço coletivo da própria comunidade".

A herança histórica de carência de políticas para as bibliotecas públicas e escolares levou a sociedade a buscar caminhos para solucionar seus problemas de acesso à informação, à leitura e ao livro. Um dos caminhos é considerado por nós como um processo natural da pratica social cidadã, visto que é pautado na ação individual ou na ação coletiva de um grupo local organizado. O outro, artificial, pois são impulsionadas por agentes coletivos externos a comunidade, os agentes do Terceiro Setor, que por meio de programas e projetos dirige suas ações à melhoria da situação de grupos vulneráveis da sociedade.

Para nós, as bibliotecas comunitárias que surgem no processo que chamamos natural é resultado da forma sócio-política de reivindicação e luta da

sociedade pelo direito à informação, à leitura e ao livro. É a prática social resultante da carência educacional e cultural vivenciadas por grande parte da população 
brasileira. Cabe lembrar que os grupos com maior poder aquisitivo têm outras formas de cobrir esse déficit, seu poder de compra lhe dá acesso à leitura e aos "bens" informacionais ofertados pelo mercado. Suas crianças e jovens freqüentam instituições de ensino privado que possuem bibliotecas escolares ricas em acervo e conduzidas por profissionais que desenvolvem serviços direcionados às necessidades de seus usuários. O fato de termos grupos com disparidades tão grandes em relação ao acesso à informação, à leitura e ao livro evidencia que o princípio da isonomia, no qual todos têm direitos iguais perante a lei, previsto na Constituição Brasileira, não está sendo respeitado.

Apesar de reconhecermos o mérito de muitas das experiências capitaneadas pelo Terceiro Setor, conforme apontamos na seção anterior, ao analisar aquelas criadas a partir dos Programas Expedição Vaga Lume, Programa Ler é Preciso, Projeto Casulo e Espaço Criança Esperança, não podemos ignorar os riscos que esse modelo carrega. Para nós, o maior deles é a valorização do "discurso neoliberal que preconiza a iniciativa individual e privada contra a ineficiência burocrática do Estado e a politização dos conflitos", apontado primeiramente por Paoli (2005, p. 386) em sua análise sobre empresas e responsabilidade social.

Da forma como se apresentam, a partir das experiências analisadas, os dois caminhos não nos parecem suficientemente firmes para que estas bibliotecas tenham condições de superar as adversidades do dia-a-dia e criar raízes fortes para se estabelecer como entidades autônomas no processo de emancipação social e democratização da informação e da leitura.

Considerando os resultados obtidos nesta pesquisa, podemos afirmar que a hipótese inicial, de que estas bibliotecas são pólos irradiadores de cultural e saber local é verdadeira, especialmente naqueles casos em que um grupo local, formado por cidadãos críticos e conscientes de sua situação econômica, social e cultural, torna o projeto de criação desses espaços efetivamente públicos. O projeto biblioteca passa a ser um desafio para enfrentar a carência de serviço público na área de educação e cultura na sua comunidade. Somente nesses casos, se apoiadas pelo poder público local, poderão transformar-se em espaços estratégicos para a implantação de políticas de integração social e cultural.

É preciso valorizar e aproveitar as iniciativas que contam com a participação ativa dos cidadãos, melhorando as suas condições, articulando-as com as instâncias 
públicas já existentes, tais como as bibliotecas públicas e, potecializando desta forma o acesso à informação, à leitura e ao livro no país.

Esses projetos dependem de recursos mínimos para se sustentar e tornar efetivas as suas ações. Sozinhas, sem apoio do Estado, essas experiências não se sustentam a longo prazo e, por conseguinte, não tornam efetivas suas ações. Por outro lado, se apoiadas somente pela iniciativa privada, correm o risco de se tornarem espaços propícios à filantropia e ao assistencialismo empresarial e distanciar-se de qualquer discussão politizadora, pois, segundo Yazbeck, a responsabilização privada do social

parte em princípio da desqualificação do poder público e portanto desconhece a possibilidade aberta pelo conflito interno no terreno das próprias políticas públicas para criar compromisso e qualidade diante dos cidadãos (YAZBECK 2001; 2005 apud PAOLI, 2005, p. 409)

Os atores envolvidos no processo de criação e manutenção de bibliotecas comunitárias precisam de mais tempo e espaço para o exercício participativo. Como Paulo Freire (2003) já nos dizia, o ato de participar não pode ser confundido com o mero ativismo. É uma prática que demanda ação e reflexão, permeada por um diálogo solidário, que, por sua vez, está baseado em um pensamento crítico. É a partir desta forma de pensar e olhar suas práticas que os atores terão condições de agir em conjunto, discutir os pontos fortes e fracos do projeto, avaliando-o e reformulando-o continuamente.

A necessidade de apoio contínuo a esses projetos, principalmente nos primeiros anos de vida da biblioteca, ficou evidenciada na pesquisa. As ações pontuais são bem vindas, mas só colaboram a partir do momento em que o projeto já tem sua sustentabilidade garantida. Do contrário, podem agir no sentido oposto, desestabilizando o grupo, como pudemos ver na experiência da parceria firmada entre a Prefeitura de Embu das Artes e a Associação Biblioteca Comunitária Zumaluma. A falta de experiência de negociação e administração dos recursos por parte dos jovens inviabilizou a parceria e gerou grande frustração ao grupo, a ponto de desarticular as relações estabelecidas inicialmente.

As diferenças estruturais e conceituais das experiências analisadas demonstram também a necessidade de pensar a biblioteca comunitária individualmente, respeitando as características locais, suas diferenças regionais, 
sociais, econômicas e principalmente culturais. Num país com as dimensões territoriais, populacionais e a diversidade cultural como o Brasil, não cabe pensar em diretrizes únicas para apoiar e fortalecer as bibliotecas comunitárias existentes, ou ainda, para ampliar o seu número. São necessárias respostas rápidas e processos flexíveis que atendam situações diversificadas e complexas.

Apesar das grandes diferenças encontradas, um ponto em comum, a ser destacado, refere-se à forte atuação dos jovens nesses projetos. Nas periferias urbanas, os jovens aparecem como os protagonistas centrais. Por meio de seu engajamento nas questões culturais e educacionais, os jovens demonstraram que têm muito a ensinar com suas redes sociais, práticas inovadoras e regras de convivência. Ao contrario do que prega o discurso que move a sociedade atual em relação aos jovens pobres da periferia, que carrega a idéia de que os jovens, principalmente os pobres, são um problema social e, portanto, objeto de ação do Estado e das instituições sociais (SILVA; BARBOSA, 2005).

Muitos autores (LOPES, 2003; SILVA; BARBOSA, 2005; SOARES; BILL; ATHAYDE, 2005; DUARTE, 2006) têm realizado estudos e apresentado relatos que demonstram a importância dos movimentos juvenis nas intervenções sociais.

As experiências analisadas em regiões urbanas, criadas e idealizadas por jovens, são evidentemente mais abertas à ação participativa do que as experiências capitaneadas por ações individuais ou por entidades do Terceiro Setor. São exemplos marcantes as bibliotecas comunitárias Livro-Pra-Quê-Te-Quero e Solano Trindade.

A pesquisa nos mostrou também que, apesar de algumas bibliotecas comunitárias apresentarem um bom desempenho no que se refere ao estímulo à leitura, como é o caso das bibliotecas da região norte do país, elas não conseguem chegar ao nível de especialização a ponto de trabalhar a informação pública. Este dado nos faz concluir que, apesar do forte trabalho com a leitura, são poucas as bibliotecas comunitárias, que conseguem avançar na gestão e transferência da informação pública, sendo que a maioria deixa a cargo da mídia comercial esse serviço. É o rádio, a televisão e a internet que cumprem essa função. É fato também que o mesmo acontece em relação às bibliotecas públicas, como já identificado por outros autores em pesquisa sobre o assunto (ALMEIDA JUNIOR, 1995; MILANESI, 2002; LIMA, 2006). 
No entanto, acreditamos que ao somar os esforços da biblioteca pública e comunitária poderíamos trabalhar no sentido de mudar esse cenário e minimizar os problemas informacionais do país. Afinal, não podemos nos eximir desta tarefa, deixando que os veículos midiáticos sejam os únicos a cumprir a função de dar acesso à informação à população brasileira. Gonzalez de Gomes (1999, p. 7) apresenta com propriedade os diferenciais da informação, ou seja, "a singularidade que especifica o que é informação para cada agente (individual ou coletivo)". E esclarece que,

é o ator social que indica em que caso a informação é o caso, ao mesmo tempo que, para construir um valor informacional, busca elementos em sua experiência, suas redes de integrações e em sistemas armazenados de artefatos informacionais que, nas sociedades contemporâneas, se desenvolvem de modo hegemônico ou monopolista (GONZALES DE GOMES, 1999, p. 7).

Aprendemos nas Escolas de Biblioteconomia e Ciência da Informação que é a partir do diálogo que o bibliotecário tem condições de criar serviços de informação pública que atendam as demandas locais existentes. Nesse sentido, é preciso estar atento para identificar quais informações são importantes para o cidadão comum, o trabalhador, o desempregado, a dona-de-casa, as crianças e jovens que não freqüentam a escola, os idosos, as pessoas com necessidades especiais, entre tantos outros.

É a partir desse contato e aproximação que é possível identificar necessidades e construir sistemas de informação pública local. Com o avanço das tecnologias, esses sistemas podem e devem ser gerenciados pelas bibliotecas públicas e, a partir de um trabalho colaborativo, ser potencializados pelas bibliotecas comunitárias. Segundo o documento Projeto Político de Apoio Local (2006, p. 17), "organizar um bom sistema local de informação constitui provavelmente uma das ações de melhor relação custo-benefício". O mesmo relatório ressalta ainda que "não há participação cidadã sem informação organizada".

A Biblioteconomia e a Ciência da Informação dedicam seus estudos ao processo de geração e circulação da informação e têm condições de desenvolver metodologias para a criação de sistemas eficazes de informação que possam ser gerenciados localmente. Cabe ao Estado investir na formação de profissionais aptos a implementar e gerenciar esse processo. 
Como constatamos, as bibliotecas comunitárias estão dispersas pelo país e surgem no lugar da biblioteca pública e escolar. Ocupam um espaço vazio e determinam princípios e métodos para se estabelecer. Muitas delas são o resultado de programas idealizados por organizações do Terceiro Setor, que contam com a aprovação da Lei de Incentivo à Cultura do Ministério da Cultura, ou seja, são espaços criados com dinheiro obtido por meio de isenção fiscal. Os recursos financeiros, que viabilizam a doação de acervos e equipamentos e a formação de pessoal, constituem dinheiro público administrado com autorização, porém sem participação, do Estado.

Lembramos que esta pesquisa foi baseada na análise da experiência da biblioteca comunitária e não no projeto de responsabilidade social de empresas. No entanto, ao nos depararmos com esta formula de obtenção de recursos num projeto de pesquisa que se propõe a pensar políticas públicas para bibliotecas, passa a ser imperativo refletir sobre a forma como o Estado se omite nesse processo.

Para nós, é importante a participação da empresa nesse contexto, porém a falta de regulamentação para a aplicação de recursos públicos na área de bibliotecas pode piorar ainda mais o acesso da população à informação, à leitura e ao livro. Se considerarmos que esses são direitos dos cidadãos, firmados pela Constituição Brasileira, podemos dizer que o Estado está transferindo para a esfera privada sua responsabilidade em relação a esse serviço. Desta forma, resgatando o pensamento de Milton Santos (2000), podemos dizer que, mais do que omisso, o Estado está agindo de modo permissivo.

Parece-nos que a situação das poucas bibliotecas públicas e escolares no país geram o que Oliveira (1999, p. 57) chama de "desnecessidade do público". Faz com que a elite empresarial, que se vê politicamente auto-suficiente em relação a um Estado burocrático e ineficaz, apresente seus projetos de responsabilidade social voltados para a criação de bibliotecas comunitárias como respostas ao problema.

Autores como Francisco de Oliveira (1999), Milton Santos (2000), Maria Célia Paoli (2005) e Myrthes Macedo (2005) vêm discutindo e apontando a ambigüidade entre os interesses privados e a ação pública que se estabelece nesse campo. No Brasil, como já vimos anteriormente, é a partir da década de 1990 que esta forma de gestão social se estabelece, envolvendo novos atores sociais como parceiros do Estado na provisão e gestão de bens e serviços sociais públicos. 
Esse movimento vem se somar às práticas sociais que estão sendo incorporadas pela sociedade civil como um fator de responsabilidade social, seguindo, no entanto, o modelo do mercado. Segundo Paoli (2005, p. 414),

[...] essas iniciativas marcam o lado positivo da presença empresarial mobilizadora de energias de doação que se remetem discursivamente à cidadania, e nada se poderia dizer contra elas se funcionassem dentro de uma sociedade apoiada em garantias reais de direitos universalizados.

Para nós, apesar de estarmos na era marcada pela desregulamentação, a cultura e, especificamente as bibliotecas, assim como outras áreas, precisam de marcos regulatórios, marcos constituídos por um conjunto de leis, adequadas às nossas diferentes realidades, passiveis de serem aplicadas e acompanhadas de mecanismos que garantam o seu cumprimento. Marcos que impõem restrições à ação desordenada dos atores públicos e privados e que possam ser configurados como fatores de qualidade para a área.

Esses marcos regulatórios deveriam permear todas as ações governamentais referentes às bibliotecas que estão sendo implementadas pelos órgãos públicos em todos os níveis, federal, estadual e municipal. Do Programa Federal Mais Cultura ao Programa São Paulo um Estado de Leitores. Sem deixar de lado os recursos concedidos pelo BNDES e outras agencias de fomento governamental. A partir deles é que seriam idealizadas e administradas as relações entre as diversas intervenções que partem do próprio Estado, capitaneadas pelos diversos ministérios, tais como o SNBP, o PROLER e o PNLL vinculados ao Ministério da Cultura, o Projeto Arca da Letras do Ministério da Agricultura, assim como os programas de leitura vinculados ao Ministério da Educação, PNLD, PNBE e PNBEM. Como vimos anteriormente, apesar do atual governo caminhar no sentido de melhorar esta situação, efetivamente esses programas continuam atuando isoladamente.

Além de regular as relações internas do Estado, esses marcos serviriam também para regular as relações do Estado com a sociedade civil organizada, os movimentos sociais e as empresas no que tange a ações e projetos de acesso à informação, à leitura e ao livro.

Nesse sentido, concordamos com Marilena Chaui, quando propõe que a política cultural deva ser definida 
pela idéia da cidadania cultural, em que a cultura não se reduz ao supérfluo, entretenimento, aos padrões do mercado, à oficialidade doutrinária (que é a ideologia), mas se realiza como direito de todos os cidadãos, direito a partir do qual a divisão social das classes ou a luta de classes possa manifestar-se e ser trabalhada porque no exercício do direito à cultura, os cidadãos, como sujeitos sociais e políticos, se diferenciam, entram em conflito, comunicam e trocam suas experiências, recusam formas de cultura, criam outras e movem todo o processo cultural (CHAUI, 2008, p. 4).

Há de se pensar em maneiras criativas de intervenção, norteadas por estratégias de ação social, fomentadas pela noção de espaço público e da participação individual e coletiva. Intervenções não impositivas ou invasivas, mas, sim, construídas coletivamente e negociadas politicamente, entre os diversos interlocutores: a comunidade, a sociedade civil organizada e o Estado.

Recorrendo ao referencial teórico que subsidiou esta pesquisa e ao que aprendemos com as pessoas e as experiências que analisamos, ficou clara a necessidade de, em primeiro lugar, definir alguns princípios básicos que devem permear as estratégias para a implantação dessas políticas. São eles:

$\checkmark \quad$ o respeito à diversidade, à pluralidade cultural e às redes de sociabilidade locais;

$\checkmark$ o respeito e valorização das estratégias criativas, complexas e heterogêneas das comunidades;

$\checkmark$ o respeito e a valorização do espaço público;

$\checkmark$ o estímulo à participação como processo, ou seja, aquela que permite ao indivíduo participar da tomada de decisões tanto em relação às diretrizes culturais como aos orçamentos públicos;

$\checkmark$ a construção de sinergia entre ações e projetos;

$\checkmark$ a valorização às políticas locais.

A partir desses princípios, o Estado, juntamente com a sociedade civil, teria condições de desenhar um plano para desencadear esse processo; nesse sentido, a título de contribuição, poderíamos iniciar pensando em dois caminhos a serem seguidos concomitantemente: 
1- Políticas para apoiar e ampliar as bibliotecas públicas e escolares;

2- Políticas para que as bibliotecas públicas e escolares apóiem as bibliotecas que surgem na comunidade.

Desta forma, a partir da consolidação da biblioteca pública e escolar no país, - Estado estaria criando condições de estas instituições apoiarem as iniciativas locais, criando, assim, uma rede colaborativa de sustentação entre as diversas iniciativas e a administração pública.

A Câmara Setorial do Livro, Literatura e Leitura é o mecanismo criado pelo atual governo para a participação da sociedade civil na formulação de políticas públicas para a área. No entanto, como vimos anteriormente, a formulação é somente a primeira da etapa do processo de elaboração de políticas públicas. As outras duas etapas referem-se à implementação e à avaliação. Ou seja, ao pensarmos em políticas públicas estamos pensando em algo que envolve não só uma decisão localizada no tempo, mas uma teia de decisões e o desenvolvimento de uma série de ações ao longo de um determinado tempo.

$\mathrm{Na}$ atual conjuntura, para nós, o caminho mais sensato e promissor para viabilizar as etapas de implementação e avaliação é o de reposicionamento, requalificação e fortalecimento do Sistema Nacional de Bibliotecas Públicas, criado em 1992. Segundo Dagnino (2008, p. 123), é imprescindível que haja uma única agência de implementação de políticas públicas num determinado setor, "que não dependa de outras ou, se outras agências estiverem envolvidas, que as relações de dependência sejam pequenas em número e importância."

Entendemos que, desta forma, ao SNPB ficará a responsabilidade pela implementação dos marcos regulatórios que efetivarão a proposta de trabalho sistêmico, transformando-o no grande elo entre as bibliotecas públicas e comunitárias existentes no país. Para isso é necessário rever as formas de negociação local, envolvendo as diversas instâncias da federação e os diversos agentes, individuais e coletivos, vinculados ou não a empresas privadas.

A partir de dados cuidadosamente coletados e sistematizados sobre a situação das bibliotecas públicas e comunitárias do país, o SNBP terá o conhecimento especializado para oferecer informação e desenvolver projetos eficazes para expandir a cooperação, ampliando e diversificando os pontos de acesso à informação, à leitura e ao livro no país. Além disso, poderá assumir o papel 
do órgão vinculado à área de Biblioteconomia e Ciência da Informação que detém maior influencia sobre os governos estaduais e municipais, no que se refere ao estímulo e orientação a governadores e prefeitos para a ampliação do número de bibliotecas nas cidades brasileiras.

Para isso, é necessário, em primeiro lugar, garantir que os princípios apontados acima, que se referem ao respeito à diversidade e pluralidade cultural, assim como a valorização do espaço público e dos processos participativos, pautem a atuação desse órgão. Em segundo lugar, é necessário providenciar o reposicionamento do SNBP no Ministério da Cultura, visto que, subordinado à Fundação Biblioteca Nacional, ele está reduzido a um órgão sem autonomia e sem poder de negociação. E, em terceiro lugar, é preciso aparelhá-lo de maneira a conferir capacidade técnica a esse órgão para o desenvolvimento de um trabalho efetivo e de qualidade junto aos núcleos regionais em que atua.

É importante ressaltar que nenhum investimento será suficiente para que haja uma mudança na condução do Sistema se não houver o que Marilena Chaui (2008, p. 5) chama de uma "cultura política nova" pautada na idéia e na prática participativa.

A partir do exposto acima, apontamos algumas propostas que acreditamos passíveis de serem articuladas pelo Estado, como estratégias para a construção de políticas públicas que atendam esse segmento:

$\checkmark$ Estabelecer um plano de investimento contínuo e crescente para as bibliotecas públicas e comunitárias de maneira a cobrir as demandas nacionais;

$\checkmark$ Ampliar a descentralização de recursos financeiros para os municípios, condicionando os repasses à criação e manutenção de bibliotecas;

$\checkmark$ Articular os diversos projetos governamentais já existentes (PNLD, PNBE, PNLEM, PROLER, Arcas das Letras, Pontos de Cultura, entre outros) estabelecendo mecanismos de comunicação e cooperação;

$\checkmark$ Fomentar os núcleos regionais, que se configurariam como subsistemas, para dar suporte às bibliotecas locais, ampliando sua atuação para incorporar também as bibliotecas comunitárias;

$\checkmark$ Criar uma rede efetiva de bibliotecas públicas e comunitárias, articulando os profissionais envolvidos, organizando as informações sobre sua localização, acervo, público, atividades e relações com a comunidade; 
$\checkmark$ Desenvolver mecanismos de monitoramento e avaliação dos serviços oferecidos pelas bibliotecas públicas e comunitárias com vista a sua constante melhoria;

$\checkmark$ Estimular as Escolas de Biblioteconomia do país a desenvolver projetos de extensão voltados para a formação de agentes locais para atuar de maneira criativa e consciente nas comunidades, no sentido de estimular e orientar a criação de bibliotecas comunitárias, assim como agentes locais para atuar na organização e administração de acervos e coleções, na construção de bancos de dados de informação pública, e na mediação de leitura;

$\checkmark$ Incentivar os estudos sobre biblioteca pública e comunitária, nas Escolas de Biblioteconomia, tanto no nível de graduação como de pós-graduação;

$\checkmark$ Estimular a criação de programas de fomento à cultura, no nível municipal, dirigidos a jovens, a exemplo do VAl, na cidade de São Paulo;

$\checkmark$ Incentivar as instituições de fomento à pesquisa a apoiarem o desenvolvimento de projetos que tenham como foco a constituição de redes de informações públicas;

$\checkmark$ Implantar metodologias de coleta de dados para construção de bancos de dados de informações públicas locais, assegurando que tanto as bibliotecas públicas como as comunitárias possam oferecer serviços que garantam a todos os cidadãos informação de qualidade.

$\checkmark$ Criar instrumentos para o estabelecimento de parcerias entre os diversos setores, fáceis de serem implantados, administrados e controlados.

$\checkmark$ Manter o estímulo a renuncia fiscal, modificando, porém, a forma de aplicação das leis que regem esse mecanismo, de maneira a ampliar o controle social e conseqüentemente a responsabilidade pública do financiamento da cultura.

$\checkmark$ Incentivar e privilegiar projetos patrocinados por empresas que tenham a biblioteca pública e comunitária como foco, de maneira a colaborar para o fortalecimento dessa instituição.

Finalizando, não podemos deixar de ressaltar três pontos que consideramos prerrogativas na elaboração de políticas públicas para bibliotecas. 
O primeiro refere-se à crença de que se quisermos reposicionar as bibliotecas nesse país temos que trabalhar no sentido de ampliar a participação da sociedade na construção de políticas públicas para elas. Sem dúvida, a criação da Câmara Setorial do Livro, Literatura e Leitura é o primeiro passo no sentido de democratizar o processo, porém, ainda pouco significativo em termos de participação, tendo em vista a sua composição representativa muito restrita. Nesse sentido, poderíamos nos pautar na experiência do Ministério do Meio Ambiente responsável pela criação de uma série de mecanismos de consulta popular: a Conferência Nacional do Meio Ambiente, a Conferência Nacional Infanto-Juvenil pelo Meio Ambiente e a Conferência do Meio Ambiente nas Escolas. Nesse caso, as Conferências mais do que espaço de participação, são espaços de mobilização e educação para a participação.

A segunda questão refere-se à necessidade de pensarmos as políticas olhando o nosso passado, o nosso presente e o nosso futuro, considerando as experiências existentes no país, que estão colocando em prática metodologias participativas, ou que, de alguma forma, estão nos mostrando novos caminhos para enfrentarmos o problema de acesso à informação, à leitura e ao livro. Na seção anterior destacamos varias experiências exemplares que poderiam servir de referência ou pelas metodologias utilizadas em sua implantação e no desenvolvimento das suas ações, ou pelo impacto que tem gerado nas suas comunidades. Nesse sentido destacamos as seguintes bibliotecas analisadas nessa pesquisa: Biblioteca Comunitária de Poços de Caldas; Biblioteca Comunitária Casulo, Biblioteca Comunitária Ler é Preciso da Coopamare, Biblioteca Comunitária Livro-Pra-Quê-Te-Quero, Biblioteca Comunitária Maria da Neves Prado, Biblioteca Comunitária Solano Trindade e as bibliotecas Vaga-Lume da região norte do país.

E a terceira questão trata da avaliação. É comum encontrarmos processos que são exemplares na sua formulação e até implementação; porém, ao considerarem o sucesso inicial, desprezam a avaliação. Identificar o impacto que as políticas têm sobre a população é primordial para que seja possível viabilizar melhorias. Muitos autores indicam a ausência de parâmetros como um dos maiores obstáculos à avaliação (ALMEIDA, 2000; OAKLEY; CLAYTON, 2003). Nesse sentido, caberia ao SNBP a construção de indicadores para acompanhar os resultados, identificar problemas e analisar se os pressupostos iniciais das políticas públicas em questão são válidos e estão sendo contemplados. As informações que 
uma agência desse porte pode oferecer e deve colocar a disposição da Câmara Setorial responsável pela formulação das políticas públicas para a área, em grande parte vem do monitoramento e avaliação dos projetos implementados por ela. Entendemos que tudo isto faz parte de um processo cíclico que é realimentado continuamente, é a "rede de informação sobre a informação", como afirma Gonzales de Gomes (1999, p. 26). 


\section{CONSIDERAÇÕES FINAIS}

Para nós, os resultados desta pesquisa constituem-se em um conjunto de saberes sobre as bibliotecas comunitárias e os processos participativos no país, construído a partir de questionamentos, olhares, análises e reflexões pautadas em teorias biblioteconômicas, sociológicas e antropológicas.

As discussões e reflexões feitas sobre as práticas sociais e os processos de participação nos dias de hoje, envolvem contextos econômicos, sociais, políticos e culturais. Entendemos que as mesmas estão vinculadas a questões democráticas, a iniciativas locais. de mobilização e lutas e são protagonizadas por grupos de pessoas ativistas e/ou indivíduos que assumem a liderança de movimentos populares.

As observações foram pautadas nos aspectos humanos, nos movimentos e dinâmicas locais. Cada uma das visitas e cada um dos entrevistados nos ensinaram alguma coisa muito importante. As pessoas envolvidas nesses projetos são lideranças sensíveis que estão acostumadas a passar por situações de extrema necessidade e, no entanto, conseguem fazer a diferença num mundo tão adverso. De forma ativa e contrastante enfrentam o cotidiano da exclusão de acordo com suas histórias coletivas, trajetórias individuais e características socioculturais e geográficas das localidades em que se encontram.

A diversidade cultural do país ficou evidenciada nas experiências analisadas, assim como os campos de tensão que afloram nesses projetos. Levantamos e analisamos dados a respeito de bibliotecas comunitárias localizadas nos extremos do país, da comunidade rural do Estado de Roraima, na região Norte à comunidade urbana, liderada por grupos de jovens nas favelas da maior metrópole da América Latina, a cidade de São Paulo. Apesar das grandes diferenças entre as experiências, pudemos identificar a importância que as bibliotecas comunitárias têm nesses espaços de conflito. Acreditamos que isso se dá em função da crença que esses grupos têm na sua comunidade.

Essa biblioteca age como um espaço de negociação, de apropriação e de resgate da identidade. E a atividade que permeia todo esse processo é a leitura, seja a leitura individual, coletiva ou mediada. Sobre esse aspecto, cabe lembrar que temos um déficit imenso de leitura e de leitores no país. Se o ensino formal não dá 
conta desta demanda, por meio das escolas e de suas bibliotecas, e se não existem bibliotecas públicas suficientes para atender a necessidade de auto-formação da população, a criação da biblioteca comunitária passa a ser o caminho natural encontrado pelas comunidades locais para apoiar uma das mais importantes ferramentas de emancipação do homem, a leitura.

Não podemos dizer que as experiências analisadas trabalham com a informação de acordo com os conceitos biblioteconômicos. Elas cumprem muito mais a função de sala de leitura do que de biblioteca propriamente dita. O próprio Devanir Amâncio, um defensor da biblioteca comunitária, reconhece isso. No entanto, o estudo demonstra que elas têm impactado de maneira profunda determinados grupos e comunidades, mudando hábitos, comportamentos e agindo como um espaço transformador, inclusive perturbando a lógica de entendimento da tradicional tipologia das biblioteca na área da Biblioteconomia. Portanto, cabe a pergunta aos pesquisadores, professores e alunos dos cursos de Biblioteconomia será que não está na hora de reformularmos o paradigma da biblioteca pública?

A partir dos resultados obtidos podemos afirmar que há um espaço aberto na área de Biblioteconomia que está sendo ocupado pelo protagonismo social.

As bibliotecas públicas de nosso país não contam com recursos apropriados para desenvolverem suas ações e também não contam com a efetiva participação da população. Essas instituições públicas, apesar de idealmente serem criadas para atender a uma comunidade local, agem como espaços de prestação de serviço, sem nenhum vínculo com as lideranças e agentes locais. Também não estimulam a articulação com outros agentes públicos de áreas que poderiam ser consideradas complementares, tais como educadores, agentes sociais ou de saúde. Não trabalham no sentido de criar mecanismos que garantam o estabelecimento de processos participativos. São pouquíssimas as associações de amigos da biblioteca que existem e das poucas existentes, muitas estão desativadas.

Os resultados da pesquisa demonstraram que é principalmente por meio das Leis de Incentivo que as empresas e o Terceiro Setor estão apoiando os projetos analisados, ou seja, as ações nesta área estão sendo financiadas com dinheiro público, porém, sem a participação do Estado. Se esses recursos estivessem sendo destinados à criação e manutenção de bibliotecas públicas e escolares talvez tivéssemos outra realidade nacional a ser analisada. As relações entre Estado e as organizações da sociedade civil, nesses casos, são regidas unicamente por esta lei. 
Já as relações do Estado com grupos de jovens ou movimentos sociais dependem das relações políticas estabelecidas localmente, deixando os grupos vulneráveis a pressões e trocas de favores partidários. Não podemos esquecer que a nossa sociedade, ainda hoje, é permeada pelo autoritarismo, paternalismo e clientelismo.

Acreditamos que conseguimos responder às perguntas iniciais, desencadeadoras desta pesquisa: por que e como surgem as bibliotecas comunitárias? Quem são os atores que atuam nesses projetos? Como se estabelecem e se articulam na sociedade? Quais os impactos que geram na coletividade? Qual o papel da Biblioteconomia e da Ciência da Informação nesses processos? E por fim, quais políticas públicas estão sendo implementadas para apoiá-las?

Entretanto, ao longo do processo de pesquisa e reflexão, novas e importantes questões foram sendo formuladas. Por exemplo, até que ponto as organizações do Terceiro Setor, que estão envolvidas na implementação de bibliotecas comunitárias, estão contribuindo para a conservação, ou para a transformação da estrutura do campo de forças e lutas nos espaços sociais em que atuam? Afinal, há o risco da negação dos conflitos, legítimos e próprios do ambiente participativo e da busca da eficácia destas ações que tendem a seguir os padrões de mercado e operam segundo os princípios do consumo da informação, da leitura e do livro.

Os resultados evidenciaram também a não-participação de profissionais da área de Biblioteconomia e Ciência da Informação nesses projetos. São poucas as bibliotecas comunitárias que contam com a colaboração ou o trabalho desse profissional. Isto nos remete a uma outra questão: será a não-participação dos bibliotecários uma forma de negação dessas experiências? E mais, qual o compromisso e qual a responsabilidade do bibliotecário, como indivíduo, com a pluralidade da biblioteca comunitária?

Outra questão importante a se destacar é a necessidade de colocarmos em prática o efetivo acesso à informação assegurado a todos os cidadãos na Constituição de 1988. Apesar da ampliação de estudos e pesquisas sobre as relações entre a informação e o conhecimento, na área da Biblioteconomia e da Ciência da Informação, com suas diversas abordagens, cognitivas, comunicacionais, ou ainda tecnológicas, parece-nos que as mesmas não conseguiram sair do campo acadêmico. Enquanto isso, por meio da pratica social, as comunidades periféricas 
estão tentando ultrapassar a primeira e enorme barreira que os separa do mundo digital - 0 acesso à leitura.

A partir dos resultados e da proposta apresentada nesta pesquisa consideramos importante levantar ainda alguns pontos críticos no Programa Mais Cultura lançado recentemente pelo governo Federal e abordado nas seções anteriores. O primeiro refere-se a incorporação das bibliotecas comunitárias como Pontos de Leitura, atrelados aos Pontos de Cultura, dentro do eixo "Cidade Cultural". Para nós, o mais adequado deveria ser incorporá-las às Bibliotecas Públicas dentro do eixo "Cultura e Cidadania". O segundo refere-se ao não estabelecimento de uma agencia responsável pela implementação e avaliação dos impactos dos investimentos previstos pelo Programa e, em terceiro lugar, a valorização da construção de novos prédios e compra de acervo em detrimento da formação e qualificação de pessoal para atuar nesses espaços.

Acreditamos que esse poderia ser o momento apropriado para o Estado garantir o fortalecimento e a ampliação das bibliotecas públicas no país, incorporando as iniciativas locais de acesso à informação, à leitura e ao livro. No entanto, mais uma vez, o governo corre o risco de transformar esse programa numa ação pontual criando uma nova "marca" para as bibliotecas comunitárias. Nesse caso, consideramos que o Estado opta pela redução e esvaziamento do sentido da instituição biblioteca.

É importante esclarecer que reconhecer a importância das experiências locais não significa reduzir a Biblioteconomia ao nível de uma única escala geográfica ou, ainda, a uma escala mínima de seu potencial. Pelo contrário, afirma a importância dessas experiências como práticas solidárias, que apoiadas pelo Estado, pelas universidades e seus especialistas e associadas aos serviços oferecidos pela biblioteca pública, poderiam ser potencializados de maneira exponencial.

Acreditamos que quanto mais informação organizada e reflexões sobre essas experiências, maior será a possibilidade de conscientização e formação de pessoal para defender a instituição biblioteca e atuar em uma área de fundamental importância para o contexto brasileiro. As especificidades que as caracterizam, ao serem refletidas, praticadas e assimiladas, darão aos profissionais uma nova dimensão sociocultural, necessária para a compreensão de sua atuação no âmbito da Biblioteconomia e Ciência da Informação. 
O que identificamos nesta pesquisa é que a sociedade está fazendo história, fazendo política e, principalmente, está democratizando o acesso à informação, à leitura e ao livro por meio desses projetos. Resta ao Estado fazer a sua parte de maneira a regular os investimentos, traçar diretrizes para a qualificação destas iniciativas, apoiar aquelas que comprovadamente estão impactando suas comunidades e estimular a ampliação do número de bibliotecas comunitárias pelo país. 


\section{REFERÊNCIAS}

AB'SÁBER, Aziz Nacib. Bibliotecas comunitárias: parte 1. Scientific American Brasil, São Paulo, n. 40, p. 98, set. 2005a.

AB'SÁBER, Aziz Nacib. Bibliotecas comunitárias: acervos. Scientific American Brasil, São Paulo, n. 41, p. 114, out. 2005b.

AB'SÁBER, Aziz Nacib. Bibliotecas comunitárias: estratégia. Scientific American Brasil, São Paulo, n. 42, p. 98, nov. 2005c.

AÇÃO EDUCATIVA. Políticas e práticas de leitura no Brasil. São Paulo: Ação Educativa, 2003.

ALMEIDA, Maria Christina Barblosa. Planejamento de bibliotecas e serviços de informação. Brasília: Briquet de Lemos, 2000.

ALMEIDA, Maria Christina Barbosa; MACHADO, Elisa Campos. Biblioteca comunitária em pauta. In: ENCONTROS COM A BIBLIOTECA, 2006, São Paulo. Bibliotecas comunitárias e populares: diálogo com a universidade, São Paulo: Itaú Cultural, 2006. Disponível em:

$<$ http://www.itaucultural.org.br/index.cfm?cd_pagina=2405> Acesso em: 04 jan. 2007.

ALMEIDA JUNIOR, Oswaldo Francisco de. Biblioteca pública: ambigüidade, conformismo e ação guerrilheira do bibliotecário. São Paulo: APB, 1995. (Ensaios APB, 15)

ALMEIDA JUNIOR, Oswaldo Francisco de. Bibliotecas públicas e bibliotecas alternativas. Londrina: Editora UEL, 1997.

ALMEIDA JUNIOR, Oswaldo Francisco de. A AIDS e a Biblioteconomia. Boletim IN:FORMA, São Paulo, v. 2, n. 3, p. 3, jul./set. 1989

AMORIM, Ana Margareth do Nascimento. Bibliotecas comunitárias e 0 processamento do seu acervo. 2006. Trabalho de Conclusão de Curso-Escola de Biblioteconomia, Universidade Federal do Estado do Rio de Janeiro, Rio de Janeiro, 2007.

ARENDT, Hanna Responsabilidade e julgamento. São Paulo: Companhia das Letras, 2004.

ARRUDA, Antonio. Para construir leitores. Folha Online, São Paulo, 29 set. 2004. Disponível em: http://www1.folha.uol.com.br/folha/sinapse/ult1063u931.shtml Acesso em: 27 ago. 2007.

ASSY, Bethânia. "Faces privadas em espaços públicos": por uma ética da responsabilidade. In: ARENDT, Hanna Responsabilidade e julgamento. São Paulo: Companhia das Letras, 2004. p. 31-60.

ASSOCIAÇÃO BRASILEIRA DE NORMAS TÉCNICAS. NBR 16001:

Responsabilidade social: sistema da gestão: requisitos. Rio de Janeiro, 2004. 
ASSOCIAÇÃO VAGA LUME. Expedição Vaga Lume: nossos programas. São Paulo: Associação Vaga Lume, c2005. Disponível em: <http://www.expedicaovagalume.org.br/site/nosso_expedicao.asp\#> Acesso em: 1 jul. 2008.

ASSOCIAÇÃO VAGA LUME. Iluminando caninhos da Amazônia. São Paulo: Associação Vaga Lume,[2006?].

BADKE, Todêsca. Biblioteca popular: uma experiência no bairro das Laranjeiras. Palavra-Chave, São Paulo, n. 4, p. 18-9, maio, 1984.

BALAZINA, Afra. Sem-teto faz biblioteca em prédio invadido. Folha de S. Paulo, São Paulo, 1 fev. 2006. Cotidiano, Literatura subterrânea, p. C2.

BARATIN, Marc; JACOB, Christian (Dir.). O poder das bibliotecas: a memória dos livros no Ocidente. 2. ed. Rio de Janeiro: UFRJ, 2006.

BARRETO, Aldo de Albuquerque. A questão da informação. São Paulo em Perspectiva, São Paulo, v. 8, n. 4, p. 3-8, 1994.

BARROS, Maria Helena Toledo Costa de; LEMOS, Charlene K. Bibliotecas comunitárias em regiões de exclusão social na cidade de São Paulo. In: ENCONTRO NACIONAL DE ESTUDANTES DE BIBLIOTECONOMIA, DOCUMENTAÇÃO, GESTÃO E CIÊNCIA DA INFORMAÇÃO, 26., Curitiba. Anais eletrônicos ... Curitiba: UFPR, 2003. Disponível em:

$<\mathrm{http}: / /$ www.decigi.ufpr.br/anais_enebd/documentos/oral/artigoenebd.rtf> Acesso em: 20 jun. 2006.

BATTLES, Matthew. A conturbada história das bibliotecas. São Paulo: Planeta, 2003.

BAUMAN, Zygmunt. Comunidade: a busca por segurança no mundo atual. Rio de Janeiro: Zahar, 2003.

BAUMAN, Zygmunt. O mal-estar da pós-modernidade. Rio de Janeiro: Zahar, 1998.

BELFRAGE, Joneta. Advocacy for democracy II. In: KRANICH, Nancy (Ed.).

Libraries \& democracy: the cornerstones of liberty. Chicago: ALA, 2001. p. 208-211.

BERARDI, Franco. O futuro da tecnosfera de rede. In: MORAES, Denis de (Org.) Por uma outra comunicação: mídia, mundialização cultural e poder. Rio de Janeiro: Record, 2003.

BIBLIOTECA NACIONAL (Brasil). Sistema Nacional de Bibliotecas Públicas. Biblioteca pública: princípios e diretrizes. Rio de Janeiro: FBN, 2000.

BIBLIOTECA NACIONAL (Brasil). Sistema Nacional de Bibliotecas Públicas. Histórico. 2006. Disponível em: <http://catalogos.bn.br/snbp/historico.html> Acessado em: 14/01/2008.

BIBLIOTECA NACIONAL (Brasil). Sistema Nacional de Bibliotecas Públicas. Relatório anual. [2006?]. Disponível em: <http://catalogos.bn.br/snbp/> Acessado em: 02/03/2007.

BNDES paga parceria de Niemeyer e pedreiro. Folha de S. Paulo, São Paulo, 28 out. 2005. Cotidiano, Literatura concretista, p. C5.

BOFF, Leonardo. Ethos mundial: um consenso mínimo entre os humanos. Rio de Janeiro: Sextante, 2003. 
BORNSTEIN, David. Como mudar o mundo: empreendedores sociais e o poder das novas idéias. Rio de Janeiro: Record, 2006.

BOURDIEU, Pierre. Razões práticas: sobre a teoria da ação. 7. ed. Campinas: Papirus, 2005.

BRASIL. Decreto no 6.226, de 4 de outubro de 2007. Institui o Programa Mais Cultura. Diário Oficial [da] República Federativa do Brasil, Poder Executivo, Brasília, DF, 5 out. 2007a. Disponível em:

$<$ http://www.cultura.gov.br/legislacao/decretos/index.php?p=30349\&more =1\&c=1\&pb =1> Acesso em: 14 fev. 2007.

BRASIL. Ministério da Cultura. Apresentação do Programa Mais Cultura. Brasília: Ministério da Cultura, 2007. Disponível em:

<http://www.cultura.gov.br/site/2008/05/29/mais-cultura-para-o-brasil-e-o-povobrasileiro-5/>. Acesso em: 14 fev. 2008.

BRASIL. Ministério da Cultura. Pontos de cultura. Brasília: Ministério da Cultura, [2007?]. Disponível em:

<http://www.cultura.gov.br/programas_e_acoes/programa_cultura_viva/pontos_de_c ultura/index.php>. Acesso em: 14 fev. 2008.

BUFORD, Bob. Os baby bomers, as igrejas e os empreendedores podem transformar a sociedade. In: HESSELBEIN, Francis et. al. A comunidade do futuro: idéias para uma nova comunidade. São Paulo: Futura, 1998. p. 44-54.

BURKE, Peter. Uma história do conhecimento: de Gutemberg a Diderot. Rio de Janeiro: Zahar, 2003.

CACCIA BAVA, Silvio. Mobilização social e a crise de governabilidade na América Latina. In: MOBILIZAÇÃO cidadã e inovações democráticas nas cidades. Ed. especial FSM 2005. São Paulo: POLIS, 2005. p. 06-13.

CALABRE, Lia. Políticas culturais no Brasil: balanço e perspectivas. In: Encontro de Estudos Multidisciplinares em Cultura, 3., 2007, Salvador. Anais eletrônicos ...

Disponível em: <http://www.cult.ufba.br/enecult2007/LiaCalabre.pdf.> Acesso em: 16 jan. 2007.

CASTRO, Fabio de. A experiência de Aziz Ab'Saber na maior ocupação de São Paulo. Agência Repórter Social, São Paulo, 17 fev. 2006. Disponível em: $<$ http://www.reportersocial.com.br/noticias.asp?id=1117\&ed=teto> . Acesso em: 29/07/2008.

CHAUI, Marilena de Souza. Cidadania cultural: o direito à cultura. São Paulo: Fundação Perceu Abramo, 2006.

CHAUI, Marilena de Souza. Convite à filosofia. 12. ed. São Paulo: Ática, 1999.

CHAUI, Marilena de Souza. Cultura e democracia. Cadernos de Pensamento Crítico Latino-Americano: encarte CLASCSO, 5, 2008.

CHAUI, Marilena de Souza. Introdução à história da filosofia: dos pré-socráticos a Aristóteles. 2. ed. São Paulo: Companhia das Letras, 2002. v. 1.

CHAUI, Marilena de Souza. O que é ideologia. 31. ed. São Paulo: Brasiliense, 1990.

CHAUI, Marilena de Souza. O que é política? In: NOVAES, Adauto (Org.). $O$ esquecimento da política. Rio de Janeiro: Agir, 2007. p. 27-54. 
COELHO NETO, José Teixeira. O que é ação cultural. São Paulo: Brasiliense, 2001.

COELHO NETO, Jose Teixeira. Moderno e pós-moderno: modos e versões. 5. ed. São Paulo: lluminuras, 2005.

COLSON, John C. The United States: an historical critique. In: MARTIN, William (Ed.) Library services to the disadvantaged. London: Clive Bingley, 1975. p. 32-46.

COSTA, Greiner; DAGNINO, Renato (Org.). Gestão estratégica em políticas públicas. Rio de Janeiro: T. Mais.Oito, 2008.

CRAWFORD, John. The community library in scottish history. In: IFLA Council and General Conference, Glasgow, 68, 2002. Disponível em:

$<$ http://209.85.165.104/search?q=cache:pYKw0HrDd10J:www.ifla.org/IV/ifla68/paper s/063-111e.pdf+community+library+in+scottish+history\&hl=pt-BR\&ct=clnk\&cd=1>. Acesso em: 10 jan. 2008.

CROKER, S. K. Library services to Indian and Pakistani immigrants in Great Britain. . In: MARTIN, William (Ed.) Library services to the disadvantaged. London: Clive Bingley, 1975. p. 119-129.

CUNALI, Marina; BRANCO, Cecília. A dinâmica do cenário das bibliotecas públicas de São Paulo. São Paulo: SMC/DBP, 2002. CD-ROM.

DAGNINO, Renato (Coord.). Metodologia de análise de políticas públicas. In: COSTA, Greiner; DAGNINO, Renato (Org.). Gestão estratégica em políticas públicas. Rio de Janeiro: T. Mais.Oito, 2008. p. 87-140.

DINHA. Eu, mulher. Le monde diplomatique Brasil, São Paulo, ano 1, n. 8, p. 21, 2008.

DISTRITO FEDERAL (Brasil). Secretaria de Estado de Cultura. O Conjunto Cultural da República: uma dívida de mais de 40 anos. Brasília: SEC, [2006?]. Disponível em: < http://www.sc.df.gov.br/paginas/ccr/ccr_01.htm>. Acesso em: 17 jun. 2008.

DOWBOR, Ladislau. Os novos espaços do conhecimento. 1994. Disponível em: $<$ http://dowbor.org/conhec.asp> Acesso em: 19 jun.2007.

DOWBOR, Ladislau. Redes de apoio ao desenvolvimento local: uma estratégia de inclusão produtiva. 2006. Disponível em:

<http://dowbor.org/06redesinclprodutiva.doc> Acesso em: 19 jun. 2007.

DOWBOR, Ladislau. Da globalização ao poder local: a nova hierarquia dos espaços. 1995. Disponível em: <http://dowbor.org/5espaco.asp> Acesso em: 19 jun. 2007.

DUARTE, Neide. Frutos do Brasil: história de mobilização juvenil. São Paulo: Aracati, 2006.

ENCONTROS COM A BIBLIOTECA, 2006, São Paulo. Bibliotecas comunitárias e populares: diálogo com a universidade, São Paulo: Itaú Cultural, 2006. 2 DVDs.

ENCONTRO INTERNACIONAL LITERATURA E AÇÃO CULTURAL, 2008, São Paulo. Grupo de trabalho bibliotecas comunitárias. São Paulo: SESC Pinheiros, 2008.

FACCION JUNIOR, Carlos Magno. Biblioteca comunitária: uma alternativa entre a biblioteca pública e a biblioteca escolar. 2005. Trabalho de Conclusão de Curso- 
Escola de Biblioteconomia, Universidade Federal do Estado do Rio de Janeiro, Rio de Janeiro, 2005.

FINNEGAN, Gerry. Public library and community development. In: MARTIN, William (Ed.) Library services to the disadvantaged. London: Clive Bingley, 1975. p. 32-46. FREITAG, Barbara; ROUANET, Sérgio Paulo (Org.). Habermas: sociologia. São Paulo: Ática, 1980.

FLUSSER, Victor. A biblioteca como instrumento de ação cultural. Revista da Escola de Biblioteconomia da UFMG, Belo Horizonte, v. 12, n. 2, p. 145-169, set., 1983.

FLUSSER, Victor. Uma biblioteca verdadeiramente pública. Revista da Escola de Biblioteconomia da UFMG, Belho Horizonte, v. 9, n. 2, p. 131-8, set., 1980.

FLUSSER, Victor. O bibliotecário animador: considerações sobre sua formação.

Revista da Escola de Biblioteconomia da UFMG, Belho Horizonte, v. 11, n. 2, p. 230236, set., 1982.

FREIRE, Paulo. Pedagogia da autonomia: saberes necessários à prática educativa. 34. ed. São Paulo: Paz e Terra. 2006.

FREIRE, Paulo. Pedagogia do oprimido. 35. ed. São Paulo: Paz e Terra, 2003.

FREITAS, Lídia Silva de. Uma leitura crítica da crise da leitura. In: LÜCK, Esther $\mathrm{H}$. et al. A informação: questões e problemas. Niterói: EDUFF, 1995. p. 39-49. (Estudos e Pesquisas; 1)

FUNDAÇÃo GETÚLIO VARGAS. Dicionário de Ciências Sociais. Rio de Janeiro: Ed. FGV., 1986.

FUNG, Archon. Receitas para esferas públicas: oito desenhos institucionais e suas conseqüências. In: COELHO, Vera Schattan P. ; NOBRE, Marcos (Org.) Participação e deliberação: teoria democrática e experiências institucionais no Brasil contemporâneo. São Paulo: Ed. 34, 2004. p. 107-130.

GANDIN, Danilo. A posição do planejamento participativo entre as ferramentas de intervenção na realidade. Currículo sem Fronteiras, v. 1, n. 1, p. 81-95, jan/jun 2001.

GIDDENS, Anthony. As conseqüências da modernidade. São Paulo: Ed. UNESP, 1991.

GIL, Antonio Carlos. Métodos e técnicas de pesquisa social. São Paulo: Atlas, 1999.

GOHN, Maria da Glória. O protagonismo da sociedade civil: movimentos sociais, ONGs e redes solidárias. São Paulo: Cortez, 2005.

GONZÁLEZ DE GOMEZ, Maria Nélida. O caráter seletivo das ações de informação. Informare: cadernos do Programa de Pós-Graduação em Ciência da Informação.

Rio de Janeiro, v. 5, n. 2, p. 7-30, jul./dez.1999.

GONZÁLEZ DE GOMEZ, Maria Nélida. Metodologia de pesquisa no campo da Ciência da Informação. DataGramaZero: Revista de Ciência da Informação, Rio de Janeiro, v. 1, n. 6, dez. 2000. Disponível em:

<http://www.dgz.org.br/dez00/Art_03.htm> Acesso em: 28 jul. 2007. 
GOROSITO LÓPEZ, Antonio. La biblioteca comunitária: uma experiência de organización social, educativa y cultural. Biblios: revista electrónica de Biblioteconlogía, Arquivología y Museología, ano 4, n. 15, p. 35-40, jun. 2003.

HABERMAS, Jurgen. Teoria de la accion comunicativa. Madrid: Taurus, 1988.

HALL, Stuart. A identidade cultural na pós-modernidade. 10. ed. Rio de Janeiro: DP\&A, 2005.

HOBSBAWM, E. Era dos extremos: o breve século XX: 1914 - 1991. 2. ed. São Paulo: Companhia das Letras, 1996.

JESUS, Marisa S. de. Implantação de bibliotecas comunitárias nos municípios do Estado da Bahia. Salvador: CEPOM, 2007. Disponível em: $<$ http://www.cinform.ufba.br/7cinform/soac/papers/41d630061c75a5256dde4897e52 7.pdf> Acesso em: 28 jul. 2008.

KISIL, Marcos. Organização social e desenvolvimento sustentável: projetos de base comunitária. In: IOSCHPE, Evelyn Berg. 3․ Setor: desenvolvimento nacional sustentado. 2. ed. São Paulo: Paz e Terra, 2000. p. 131-155.

KOBASHI, Nair Yumiko.; TÁLAMO, Maria de Fátima Gonçalves Moreira. Informação: fenômeno e objeto de estudo da sociedade contemporânea. Transinformação, Campinas, v.15 (edição especial), p.7-21, 2003.

KRANICH, Nancy (Ed.). Libraries \& democracy: the cornerstones of liberty. Chicago: ALA, 2001.

LIBRARY OF CONGRESS. Subject heading. 20. ed. Washington, LC, 1997.

LE COADIC, Yves-François. A Ciência da Informação. 2. ed. Brasília: Briquet de Lemos, 2004.

LÉVY, Pierre. A inteligência coletiva: por uma antropologia do ciberespaço. São Paulo: Loyola, 1998.

LIMA, Justino Alves. Comunidades carentes, lugares da não-informação. 2006. 164p. Tese (Doutorado)-Escola de Comunicação e Artes, Universidade de São Paulo, São Paulo, 2006.

LINS, Letícia. O "traficante de livros" de Recife: morador de favela transforma barraco em biblioteca, que recebe por dia 30 crianças e adolescentes. O Globo, Rio de Janeiro, 15 ago. 2008. O País, p. 14.

LOPES, Maria Immacolata Vassalo de. Pesquisa em comunicação: formulação de um modelo metodológico. 2. ed. São Paulo: Loyola, 1994.

LOPES, Weber. Vamos ler um livro: iniciativa de um grupo juvenil. In: AÇÃO EDUCATIVA. Políticas e práticas de leitura no Brasil. São Paulo: Ação Educativa, 2003. p. 26-33.

MACEDO, Myrtes de Aguiar. O comunitárismo na nova configuração das políticas sociais do Brasil. Em Debate. Rio de Janeiro, n. 1, 2005. Disponível em:

$<$ http://www.maxwell.lambda.ele.puc-rio.br/cgi-

bin/PRG_0599.EXE/6595.PDF?NrOcoSis=18410\&CdLinPrg=pt> Acesso em: 28 jul. 2008. 
MACEDO, Neusa Dias de; SPINELLI, Laila Gebara. Subsídios para a caracterização da biblioteca pública. Revista Brasileira de Biblioteconomia e Documentação, São Paulo, v. 20, n. 1/4, p. 71-77, jan./dez. 1987.

MACHADO, Elisa Campos. Biblioteca como prática de responsabilidade social: relatório parcial. Rio de Janeiro, 2008. Não publicado.

MANESS, Jack M. Teoria da biblioteca 2.0: Web 2.0 e suas implicações para as bibliotecas. Informação e Sociedade: Estudos. João Pessoa, v. 17, n. 1, p. 43-51, 2007. Disponível em: <http://www.ies.ufpb.br/ojs2/index.php/ies/article/view/831>. Acesso em: 21 jan. 2007.

MARTELETO, Regina Maria; RIBEIRO, Leila Beabriz. Informação e construção do conhecimento para a cidadania no terceiro setor. Informação e Sociedade: Estudos. João Pessoa, v. 11, n. 1, 2001. Disponível em:

$<$ http://www.informacaoesociedade.ufpb.br/IS1110103.htm>. Acesso em: 3 set. 2005.

MARTIN, William (Ed.) Library services to the disadvantaged. London: Clive Bingley, 1975.

MATTELART, Armand. História da sociedade da informação. São Paulo: Loyola, 2002.

McGARRY, Kevin O contexto dinâmico da informação: uma análise introdutória. Brasília: Briquet de Lemos, 1999.

MEDEIROS, Jotabê. Pacote para encarar "hipocrisia fiscal". O Estado de S. Paulo, São Paulo, 18 jun. 2008. Disponível em:

$<$ http://www.cultura.gov.br/site/2008/06/19/pacote-para-encarar-hipocrisia-fiscal/> Acesso em: 15 jul. 2008.

MILANESI, Luis. Ordenar para desordenar. 1985. Tese (Doutorado)-Escola de Comunicação e Artes, Universidade de São Paulo, São Paulo, 1985.

MILANESI, Luis. Biblioteca. Cotia: Ateliê Editorial, 2002.

MINAYO, Maria Cedília de S.; SANCHES, Odécio. Quantitativo - qualitativo: oposição ou complementaridade? Cadernos de Saúde Pública, Rio de Janeiro, v. 9, n. 3: p. 239-262, jul/set, 1993.

MORAES, Rubens, Borba de. Livros e bibliotecas no Brasil colonial. 2. ed. Brasília: Briquet de Lemos, 2006.

MORIN, Edgar. A cabeça bem-feita: repensar a reforma, reformar o pensamento. 10. ed. Rio de Janeiro: Bertrand Brasil, 2004.

MORIN, Edgar. Os sete saberes necessários à educação do futuro. 6. ed. São Paulo: Cortez, 2002.

MORISHITA, Rômulo. Proposta do diagnóstico: avaliação do Projeto "Mudando a História" na Paróquia de São Matheus. In: ENCONTROS COM A BIBLIOTECA, 2006, São Paulo. Bibliotecas comunitárias e populares: diálogo com a universidade, São Paulo: Itaú Cultural, 2006. 23, ago.2006. 1 DVD.

NASCIMENTO, Denise Morado; MARTELETO, Regina Maria. A "informação construída" nos meandros dos conceitos da teoria social de Pierre Bordieu.

Datagramazero: revista de Ciência da Informação, São Paulo, v. 5, n. 5, out. 2004. 
NOVAES, Adauto. Políticas do esquecimento. In: NOVAES, Adauto (Org.). $O$ esquecimento da política. Rio de Janeiro: Agir, 2007. p. 9-26.

NúCLEO CULTURAL FORÇA ATIVA. Rimar para a prevenção. São Paulo: Força Ativa, c2004. 1 CD.

OAKLEY, Peter; CLAYTON, Andrew. Monitoramento e avaliação do empoderamento. São Paulo: Instituto Polis, 2003.

OLIVEIRA, Francisco de. Privatização do público, destituição da fala e anulação da política: o totalitarismo neoliberal. In: OLIVERIA, Francisco; PAOLI, Maria Célia (Org.). Os sentidos da democracia: políticas do dissenso e hegemonia global. Petrópolis: Vozes, 1999. p. 55-82.

OUTHWAITE, William; BOTTOMORE, Tom (Ed.). Dicionário do pensamento social do século XX. Rio de Janeiro: Zahar, 1996.

PAOLI, Maria Célia. Empresas e responsabilidade social: os enredamentos da cidadania no Brasil. In: SANTOS, B. S. (Org.) Democratizar a democracia: os caminhos da democracia participativa. 3. ed. Rio de Janeiro: Civilização Brasileira, 2005. p. 375-418.

PASSOS, Carlos Artur Kruger (Org.). Indicadores, ONGs e cidadania: contribuições sociopolíticas e metodológicas. Curitiba: Plataforma Contrapartes Novib, 2003.

PETIT, Michèle. Os jovens e a leitura: uma nova perspectiva. São Paulo: Editora 34, 2008.

PLANO NACIONAL DO LIVRO E LEITURA. Objetivos e metas. Brasília: PNLL, 2006. Disponível em: <http://www.pnll.gov.br/> Acesso em: 30 jan. 2007.

POCHMANN, Marcio. Outra cidade é possível: alternativas de inclusão social em São Paulo. São Paulo: Cortez, 2003.

POSTER, Mark. Cidadania, mídia digital e globalização. In: MORAES, Denis de (Org.) Por uma outra comunicação: mídia, mundialização cultural e poder. Rio de Janeiro: Record, 2003. p. 315-336.

PRADO, Geraldo Moreira. Da história latente à história verdadeira: uma experiência piloto com a biblioteca comunitária. In: Foró Social de Información, Documentación y Bibliotecas, 1., 2004, Buenos Aires. Anais eletrônico ... Disponível em: < http://www.inforosocial.net/ponencias/eje04/30.pdf>. Acesso em: 10 jan. 2008.

PRADO, Geraldo Moreira. Bibliotecas comunitárias no semi-árido brasileiro: miniterritório de memória da inclusão sociocultural. 2006. Projeto de pesquisa aprovado pelo CNPq. Edital MCT/CNPq 50/2006 - Ciências Humanas, Sociais e Sociais Aplicadas, 2007. Não publicado.

PROJETO Política Nacional de Apoio ao Desenvolvimento Local: documento de conclusão. São Paulo: Instituto de Cidadania, 2006. Disponível em: <http://dowbor.org/06dlfinal.pdf.>. Acesso em: 31 jan. 2008.

PUPPIN, Terezinha. Biblioteca comunitária: um estudo da aplicação de seu conceito. 2008. Trabalho de Conclusão de Curso-Escola de Biblioteconomia, Universidade Federal do Estado do Rio de Janeiro, Rio de Janeiro, 2008.

RAFFAINI, Patrícia Tavares. Esculpindo a cultura na forma Brasil: o Departamento de Cultura de São Paulo (1935-1938). São Paulo: Humanitas, 2001. 
REDE DE INFORMAÇÃO DO TERCEIRO SETOR. O que são redes? Rio de Janeiro: Rits, [2007?]. Não paginado. Disponível em:

<http://www.rits.org.br/oquee_teste/oq_earits.cfm>. Acesso em: 12 dez. 2007.

REIS, Fábio Wanderley. Deliberação, interesses e "sociedade civil". In: COELHO, Vera Schattan P. ; NOBRE, Marcos (Org.) Participação e deliberação: teoria democrática e experiências institucionais no Brasil contemporâneo. São Paulo: Editora 34, 2004. p. 107-130.

SÁ, Célia Barbosa de. Entre o ideal e o real: as bibliotecas da Associação Comunitária Monte Azul. 2007. Trabalho de Conclusão de Curso-Escola de Comunicação e Artes, Universidade de São Paulo, São Paulo, 2007.

SADER, Emir. Século XX uma biografia não-autorizada: o século do imperialismo. São Paulo: Fundação Perseu Abreu, 2000.

SANTOS, Boaventura de Sousa (Org.) Democratizar a democracia: os caminhos da democracia participativa. 3. ed. Rio de Janeiro: Civilização Brasileira, 2005.

SANTOS, Milton. Território e sociedade: entrevista com Milton Santos. São Paulo: Ed. Fundação Perseu Abramo, 2000.

SARLO, Beatriz. Cenas da vida pós-moderna: intelectuais, arte e vídeocultura na Argentina. 3. ed. Rio de Janeiro: Ed. UFRJ, 2004.

SEVCENKO, Nicolau. A corrida para o século XXI: o loop da montanha-russa. São Paulo: Companhia das Letras, 2001.

SILVA, Fabiana Vilar. Subsídios para elaboração de uma política de seleção em bibliotecas comunitárias. 2008. Trabalho de Conclusão de Curso-Escola de Biblioteconomia, Universidade Federal do Estado do Rio de Janeiro, Rio de Janeiro, 2008.

SILVA, Franklin Leopoldo e. Política como moralidade: a banalidade da ética. In: NOVAES, Adauto (Org.). O esquecimento da política. Rio de Janeiro: Agir, 2007. p. 27-54.

SILVA, Jailson de Souza e; BARBOSA, Jorge Luiz. Favela: alegria e dor na cidade. Rio de Janeiro: Ed. SENAC Rio, 2005.

SOARES, Luiz Eduardo; BILL, MV; ATHAYDE, Celso. Cabeça de porco. Rio de Janeiro: Objetiva, 2005.

SUAIDEN, Emir. Biblioteca pública e a informação à comunidade. São Paulo: Global, 1995.

TAKAHASHI, Tadao (Org.) Sociedade da informação no Brasil: livro verde. Brasília: Ministério da Ciência e Tecnologia, 2000.

THOMAS, T. Library services to immigrants in Austrália. In: MARTIN, William (Ed.) Library services to the disadvantaged. London: Clive Bingley, 1975. p. 161-175.

TORO, José Bernardo. A construção do público: cidadania, democracia e participação. Rio de Janeiro: Ed. Senac Rio, 2005.

UMA biblioteca muitos sonhadores: Biblioteca Comunitária Ler é Preciso Coopamare São Paulo. Prosa, São Paulo, ano 2, n. 3, 2008. p. 4-5. 
UNESCO. Marco estratégico para a UNESCO no Brasil. Brasília, UNESCO, 2006. Disponível em <http://unesdoc.unesco.org/images/0014/001475/147544por.pdf > Acesso em: 31 janeiro 2008.

VERGUEIRO, Waldomiro. Bibliotecas públicas e mudança social: a contribuição do desenvolvimento de coleções. São Paulo: ECA/USP, 1990. Originalmente apresentada como tese de doutorado, Universidade de São Paulo, 1990.

VERGUEIRO, Waldomiro ; CARVALHO, Telma de. Definição de indicadores de qualidade: A visão dos administradores e clientes de bibliotecas universitárias.

Perspectivas em Ciência da Informação, Belo Horizonte, v. 6, n. 1, p. 27-40, 2001.

VERGUEIRO, Waldomiro, MACHADO, Elisa Campos, MARTIN VEGA, Arturo. La creación de bibliotecas comunitarias como herramienta para el acceso a la información y a la educación: experiencia en la favela de Heliópolis, en São Paulo (Brasil). In: Congreso iberoamericano de bibliotecologia, 2. 2007, Buenos Aires.

VERRI, Gilda Maria Whitaker. Templários da ausência em bibliotecas populares. Recife: UFPE, 1996.

VIANNA, Luiz Fernando. Pedreiro cria um dicionário de ilustres desconhecidos. Folha de S. Paulo, São Paulo, 3 dez. 2006. Cotidiano, Educação, p. C3.

WADA, Marcia Miyoko. Juventude e leitura. São Paulo: Annablume Ed., 2004.

WERLE, Denílson Luís. Democracia deliberativa e os limites da razão pública. In: COELHO, Vera Schattan P. ; NOBRE, Marcos (Org.) Participação e deliberação: teoria democrática e experiências institucionais no Brasil contemporâneo. São Paulo: Ed. 34, 2004. p. 107-156.

WOLFF, Francis. Esquecimento da política ou desejo de outras políticas? In: NOVAES, Adauto (Org.). O esquecimento da política. Rio de Janeiro: Agir, 2007. p. 55-82. 


\section{BIBLIOGRAFIA COMPLEMENTAR}

ASSOCIAÇÃO BRASILEIRA DE NORMAS TÉCNICAS. NBR 6023: informação e documentação: referências: elaboração. Rio de Janeiro, 2002.

ASSOCIAÇÃO BRASILEIRA DE NORMAS TÉCNICAS. NBR 10520: informação e documentação: citação em documentos: apresentação. Rio de Janeiro, 2002.

ASSOCIAÇÃO BRASILEIRA DE NORMAS TÉCNICAS. NBR 14724: informação e documentação: trabalhos acadêmicos: apresentação. Rio de Janeiro, 2002.

BOBBIO, Norberto Liberalismo e democracia. 6. ed. São Paulo: Brasiliense, 2005.

BRASIL. Lei o 9.998, de 17 de agosto de 2000. Institui o Fundo de Universalização dos Serviços de Telecomunicações. Diário Oficial [da] República Federativa do Brasil, Poder Executivo, Brasília, DF, 18 ago. 2000. Disponível em:

<http://legislacao.planalto.gov.br/legisla/legislacao.nsf/fraWeb?OpenFrameSet\&Fram $\mathrm{e}=$ frmWeb2\&Src=\%2Flegisla\%2Flegislacao.nsf\%2FViw_Identificacao\%2Flei\%25209. 998-2000\%3FOpenDocument\%26AutoFramed> Acesso em: 14 fev..2008.

BRASIL. Ministério da Educação. Secretaria da Educação Básica. Por uma política de formação de leitores. Brasília: Departamento de Políticas de Educação Infantil e Ensino Fundamental, 2006.

CAMPOS, Maria Luiza de Almeida. Linguagem documentária: teorias que fundamentam sua elaboração. Niterói: EDUFF, 2001.

CARVALHO, Cíntia; WADA, Márcia; LEITE, Patrícia Pereira. Jovem e ação cultural: mediação de leitura. São Paulo: Fundação Abrinq, 2000.

CARVALHO, Isabel Cristina Louzada; Kaniski, Ana Lúcia. A sociedade do conhecimento e o acesso à informação: para que e para quem? Ciência da Informação, v.29, n.3, p.33-39, set./dez. 2000.

DEMO, Pedro. Pesquisa e construção de conhecimento: metodologia científica no caminho de Habermas. 6. ed. Rio de Janeiro: Tempo Brasileiro, 2004.

FARIA, Hamilton; FERRON, Francisco (Coord.) Cartas da Cultura 1996-2003. São Paulo: Instituto Pólis, 2003.

FERREIRA, Sandra Regina Melito. Bibliotecas comunitárias: acesso e paixão pelos livros. In: CONGRESSO DE LEITURA DO BRASIL, 14, 2003, Campinas. Anais ... Campinas, julho de 2003.

FÓRUM DO PLANO NACIONAL DO LIVRO E LEITURA, 2., 2008, São Paulo. Leituras complementares. São Paulo: PNLL, 2008.

INSTITUTO ECOFUTURO. Bibliotecas comunitárias Ler é Preciso: roteiro de implantação. São Paulo: Instituto Ecofuturo, 2007.

LINDOSO, Felipe. O Brasil pode ser um país de leitores?: Política para a cultura/política para o livro. São Paulo: Summus, 2004.

LUCA, Márcia Martins Mendes de. Responsabilidade social: um diferencial competitivo para as empresas. Revista Brasileira de Contabilidade, Brasília, v. 34, n. 152, p. 24-33, mar./abr. 2005. 
MACHADO, Elisa Campos. Identidade cultural de Heliópolis: biblioteca comunitária. Informação e Sociedade: Estudos, João Pessoa, v. 15, n. 2, 2005.

MORAES, Reginaldo. Neoliberalismo: de onde vem, para onde vai? São Paulo: Ed. SENAC, 2001.

NUNES, Débora. Pedagogia da participação: trabalhando com comunidades.

Salvador: UNESCO, 2002.

OHTAKE, Ruy. Heliópolis: projeto de identidade cultural em conjunto com a comunidade. São Paulo, 2006.

ORTIZ, Renato. Cultura brasileira e identidade nacional. São Paulo: Brasiliense, 2005.

POCHMANN, Marcio ; AMORIM, Ricardo (Orgs.). Atlas da exclusão social no Brasil. São Paulo: Cortez, 2003. 2v.

SÃO PAULO (SP). Câmara Municipal. Perguntas e resposta sobre o VAl: saiba como participar do Programa para a Valorização de Iniciativas Culturais. São Paulo: Câmara, 2003.

PROSA. São Paulo: Instituto Ecofuturo, 2007-

SANTOS, Milton. Técnica, espaço, tempo: globalização e meio técnico-científico informacional. São Paulo: Hucitec, 1994.

SÃO PAULO (SP). Decreto No. 49.172 de 31 de janeiro de 2008. Diário Oficial da Cidade de São Paulo, 1 fev. 2008.

SENNETT, Richard. A cultura do novo capitalismo. Rio de Janeiro: Record, 2006.

SILVA, Jailson de Souza e; BARBOSA, Jorge Luiz; SOUZA, Ana Inês (Orgs.). Comunidades populares e universidades: olhares para o outro. Rio de Janeiro: UFRJ, 2006.

SINGER, Paul. Introdução à economia solidária. São Paulo: Fundação Perseu Abramo, 2002.

SINGER, Paul. Oito hipóteses sobre a implantação do socialismo via autogestão. Temporaes, São Paulo, n. esp., p. 23-42, 1992.

SPINK, Peter; CACCIA BAVA, Silvio; PAULICS, Veronika (Orgs.) Novos contornos da gestão local: conceitos em construção. São Paulo: Pólis, 2002.

SZAZI, Eduardo. Terceiro setor: regulação no Brasil. São Paulo: Peirópolis, 2001.

THIOLLENT, Michel. Metodologia para a pesquisa-ação. 10. ed. São Paulo: Cortez, 2000. 


\section{APÊNDICE A}

\section{Bibliotecas comunitárias como prática social no Brasil Roteiro de observação/entrevista}

\section{Identificação}

Nome:

Endereço completo:

Telefone: Contato:

2. Histórico: incluir datas

3. Cenário: dados socioculturais, econômicos e educacionais, identificar lideranças e movimentos locais.

4. Espaço: comentários sobre ambientação, layout e etc.

5. Estrutura organizacional: é legalizada? Identificar tipo e a forma de organização interna.

6. Gestão: forma de atuação (conselho, reuniões, periodicidade e etc).

7. Articulação local: apoios e parcerias. Identificar o objetivo: para envolvimento e/ou busca de recursos?

8. Intra-estrutura: mobiliário e equipamentos.

9. Estratégia de ação: projetos, serviços e metodologias utilizadas para a transmissão da informação.

10. Usuários: perfil.

11. Demanda: necessidades de leitura e informação.

12. Acervo: identificar em números (aproximado)

a. Composição do acervo:

i. Literatura infanto- juvenil;

ii. Literatura em geral: incluindo poesia, contos, crônicas e etc.;

iii. Livros didáticos e paradidáticos;

iv. Livros de cunho religioso;

v. Obras gerais e biografias;

vi. Referência: dicionários, enciclopédias e etc;

vii. Periódicos: jornais e revistas;

viii. História em quadrinhos;

ix. Outros materiais: mapas, recortes, vídeos, jogos e etc.;

b. Suporte: identificar porcentagem aproximada de material em papel e outros meios (digital, objetos reais e etc.)

13. Organização do acervo: descrever.

14. Outras observações:

Data: Pesquisador: 
APÊNDICE B

\section{Universo da pesquisa - 29 experiências analisadas}

\begin{tabular}{|c|c|c|c|c|c|c|}
\hline UF & BIBLIOTECA & IDEALIZADORES & $\begin{array}{c}\text { ATORES } \\
\text { PRINCIPAIS }\end{array}$ & $\begin{array}{c}\text { FORMAS } \\
\text { PARTICIPAÇÃO }\end{array}$ & PARCERIAS & $\begin{array}{l}\text { OBTENÇÃO } \\
\text { DADOS }\end{array}$ \\
\hline AP & $\begin{array}{l}\text { BVL de } \\
\text { Marabá }\end{array}$ & $\begin{array}{c}\text { Associação } \\
\text { Expedição Vaga } \\
\text { Lume }\end{array}$ & $\begin{array}{c}\text { Membros da } \\
\text { comunidade; } \\
\text { professores e } \\
\text { jovens } \\
\text { voluntários }\end{array}$ & $\begin{array}{l}\text { Reuniões. } \\
\text { Decisões são } \\
\text { tomadas em } \\
\text { conjunto. }\end{array}$ & $\begin{array}{l}\text { Prefeitura; } \\
\text { SME }\end{array}$ & $\begin{array}{l}\text { Entrevista } \\
\text { presencial }\end{array}$ \\
\hline $\mathrm{BA}$ & $\begin{array}{l}\text { BC Maria das } \\
\text { Neves Prado }\end{array}$ & $\begin{array}{c}\text { Professor Geraldo } \\
\text { Moreira Prado }\end{array}$ & $\begin{array}{l}\text { Membros da } \\
\text { comunidade; } \\
\text { jovens } \\
\text { contratados e } \\
\text { voluntários }\end{array}$ & $\begin{array}{c}\text { Reuniões. } \\
\text { Decisões são } \\
\text { tomadas em } \\
\text { conjunto. } \\
\text { Conselho de } \\
\text { Biblioteca atuante. }\end{array}$ & $\begin{array}{l}\text { Prefeitura; } \\
\text { Banco do } \\
\text { Nordeste; } \\
\text { Instituto } \\
\text { HSBC; MMA; } \\
\text { SERPRO }\end{array}$ & $\begin{array}{l}\text { Entrevista } \\
\text { presencial }\end{array}$ \\
\hline DF & BC T Bone & $\begin{array}{c}\text { Açougueiro Luiz } \\
\text { Amorim }\end{array}$ & $\begin{array}{l}\text { Membros da } \\
\text { comunidade } \\
\text { são } \\
\text { contratados e } \\
\text { outros } \\
\text { convidados a } \\
\text { trabalhar de } \\
\text { maneira } \\
\text { voluntária. }\end{array}$ & $\begin{array}{c}\text { Não há } \\
\text { participação da } \\
\text { comunidade na } \\
\text { tomada de decisão }\end{array}$ & $\begin{array}{l}\text { Embaixada da } \\
\text { Espanha; } \\
\text { Instituto C\&A; } \\
\text { Petrobrás. }\end{array}$ & $\begin{array}{c}\text { Observação e } \\
\text { entrevista } \\
\text { presencial. }\end{array}$ \\
\hline MA & $\begin{array}{l}\text { BVL da } \\
\text { Comunidade } \\
\text { de Santa } \\
\text { Tereza }\end{array}$ & $\begin{array}{c}\text { Associação } \\
\text { Expedição Vaga } \\
\text { Lume }\end{array}$ & $\begin{array}{l}\text { Membros da } \\
\text { comunidade } \\
\text { em geral } \\
\text { atuando de } \\
\text { forma } \\
\text { voluntária. }\end{array}$ & $\begin{array}{c}\text { Reuniões. } \\
\text { Decisões são } \\
\text { tomadas em } \\
\text { conjunto. }\end{array}$ & $\begin{array}{c}\text { SME; Pastoral } \\
\text { da Terra. }\end{array}$ & $\begin{array}{l}\text { Entrevista } \\
\text { presencial }\end{array}$ \\
\hline MG & $\begin{array}{l}\text { BC de Poços } \\
\text { de Caldas }\end{array}$ & $\begin{array}{c}\text { Fazendeiro } \\
\text { Raymond Rebetez }\end{array}$ & $\begin{array}{l}\text { Membros da } \\
\text { comunidade; } \\
\text { jovens } \\
\text { contratados e } \\
\text { voluntários }\end{array}$ & $\begin{array}{l}\text { Reuniões. } \\
\text { Decisões são } \\
\text { tomadas em } \\
\text { conjunto. }\end{array}$ & $\begin{array}{l}\text { SME; Grupo } \\
\text { Astra Café; } \\
\text { Kaffehuset } \\
\text { Friele. }\end{array}$ & $\begin{array}{l}\text { Entrevista } \\
\text { presencial }\end{array}$ \\
\hline PA & $\begin{array}{l}\text { BVL da } \\
\text { Comunidade } \\
\text { de Bengui }\end{array}$ & $\begin{array}{c}\text { Associação } \\
\text { Expedição Vaga } \\
\text { Lume }\end{array}$ & $\begin{array}{c}\text { Membros da } \\
\text { comunidade; } \\
\text { professores e } \\
\text { jovens } \\
\text { voluntários } \\
\end{array}$ & $\begin{array}{l}\text { Reuniões. } \\
\text { Decisões são } \\
\text { tomadas em } \\
\text { conjunto. }\end{array}$ & SME & $\begin{array}{l}\text { Entrevista } \\
\text { presencial }\end{array}$ \\
\hline RJ & $\begin{array}{l}\text { BC Ler é } \\
\text { Preciso de } \\
\text { Magé }\end{array}$ & Instituto Ecofuturo & $\begin{array}{c}\text { Professores } \\
\text { da escola }\end{array}$ & $\begin{array}{c}\text { Não há } \\
\text { mecanismos de } \\
\text { participação. }\end{array}$ & $\begin{array}{l}\text { SME; Grupo } \\
\text { Suzano; } \\
\text { Instituto } \\
\text { Holcim }\end{array}$ & $\begin{array}{c}\text { Observação e } \\
\text { entrevista } \\
\text { presencial }\end{array}$ \\
\hline RJ & $\begin{array}{l}\text { BC Ler é } \\
\text { Preciso Diuner } \\
\text { Mello }\end{array}$ & Instituto Ecofuturo & $\begin{array}{c}\text { Professores } \\
\text { da escola }\end{array}$ & $\begin{array}{c}\text { Não há } \\
\text { mecanismos de } \\
\text { participação. }\end{array}$ & $\begin{array}{l}\text { SME; Grupo } \\
\text { Suzano; } \\
\text { Associação } \\
\text { Casa Azul }\end{array}$ & $\begin{array}{c}\text { Observação e } \\
\text { entrevista } \\
\text { presencial }\end{array}$ \\
\hline RJ & BC Emmanuel & $\begin{array}{c}\text { Obra Social São } \\
\text { João Batista }\end{array}$ & $\begin{array}{l}\text { Membros da } \\
\text { comunidade } \\
\text { religiosa. }\end{array}$ & $\begin{array}{c}\text { Não há } \\
\text { mecanismos de } \\
\text { participação. }\end{array}$ & $\begin{array}{c}\text { Parcerias não } \\
\text { são } \\
\text { estabelecidas } \\
\text { pela biblioteca }\end{array}$ & $\begin{array}{l}\text { Entrevista } \\
\text { presencial }\end{array}$ \\
\hline RJ & $\begin{array}{l}\text { BC do Espaço } \\
\text { Criança } \\
\text { Esperança }\end{array}$ & TV Globo & $\begin{array}{c}\text { Funcionários } \\
\text { contratados } \\
\text { pelo Viva Rio }\end{array}$ & $\begin{array}{c}\text { Não há } \\
\text { mecanismos de } \\
\text { participação. }\end{array}$ & $\begin{array}{l}\text { TV Globo; } \\
\text { UNESCO; } \\
\text { Viva Rio }\end{array}$ & $\begin{array}{c}\text { Observação e } \\
\text { entrevista } \\
\text { presencial }\end{array}$ \\
\hline RJ & $\begin{array}{l}\text { BC Ler é } \\
\text { Preciso de } \\
\text { Copacabana }\end{array}$ & Instituto Ecofuturo & $\begin{array}{l}\text { Funcionários } \\
\text { da BP } \\
\text { vinculados à } \\
\text { SMC. }\end{array}$ & $\begin{array}{c}\text { Não há } \\
\text { mecanismos de } \\
\text { participação. }\end{array}$ & $\begin{array}{l}\text { SMC; Grupo } \\
\text { Suzano; } \\
\text { Associação } \\
\text { Cultural e } \\
\text { Beneficiente } \\
\text { Beit Lubavitch }\end{array}$ & $\begin{array}{c}\text { Observação e } \\
\text { entrevista } \\
\text { presencial }\end{array}$ \\
\hline
\end{tabular}




\begin{tabular}{|c|c|c|c|c|c|c|}
\hline UF & BIBLIOTECA & IDEALIZADORES & $\begin{array}{c}\text { ATORES } \\
\text { PRINCIPAIS }\end{array}$ & $\begin{array}{c}\text { FORMAS } \\
\text { PARTICIPAÇÃO }\end{array}$ & PARCERIAS & $\begin{array}{l}\text { OBTENÇÃO } \\
\text { DADOS }\end{array}$ \\
\hline RJ & $\begin{array}{l}\text { BC Paulo } \\
\text { Coelho }\end{array}$ & $\begin{array}{l}\text { Solar Meninos de } \\
\text { Luz }\end{array}$ & $\begin{array}{c}\text { Funcionários } \\
\text { contratados } \\
\text { pelo Solar } \\
\text { Meninos de } \\
\text { Luz. }\end{array}$ & $\begin{array}{c}\text { Não há } \\
\text { mecanismos de } \\
\text { participação. }\end{array}$ & $\begin{array}{l}\text { Instituto Paulo } \\
\text { Coelho }\end{array}$ & $\begin{array}{c}\text { Observação e } \\
\text { entrevista } \\
\text { presencial }\end{array}$ \\
\hline RJ & $\begin{array}{l}\text { BC Paulo } \\
\text { Freire }\end{array}$ & CEASM & $\begin{array}{l}\text { Jovens da } \\
\text { comunidade } \\
\text { contratados } \\
\text { pela CEASM. }\end{array}$ & $\begin{array}{c}\text { Não há } \\
\text { mecanismos de } \\
\text { participação. }\end{array}$ & UNIRIO & $\begin{array}{l}\text { Observação e } \\
\text { entrevista } \\
\text { presencial }\end{array}$ \\
\hline RJ & $\begin{array}{l}\text { BC Tobias } \\
\text { Barreto }\end{array}$ & $\begin{array}{l}\text { Pedreiro Evandro } \\
\text { da Silva }\end{array}$ & O idealizador & $\begin{array}{c}\text { Não há } \\
\text { participação da } \\
\text { comunidade na } \\
\text { tomada de decisão }\end{array}$ & $\begin{array}{l}\text { BNDEs; Oscar } \\
\text { Niemeyer }\end{array}$ & $\begin{array}{c}\text { Observação e } \\
\text { entrevista } \\
\text { presencial }\end{array}$ \\
\hline RR & $\begin{array}{l}\text { BVL de } \\
\text { Caracaraí }\end{array}$ & $\begin{array}{l}\text { Associação } \\
\text { Expedição Vaga } \\
\text { Lume }\end{array}$ & $\begin{array}{c}\text { Membros da } \\
\text { comunidade; } \\
\text { professores e } \\
\text { jovens } \\
\text { voluntários }\end{array}$ & $\begin{array}{l}\text { Reuniões. } \\
\text { Decisões são } \\
\text { tomadas em } \\
\text { conjunto. }\end{array}$ & SME & $\begin{array}{l}\text { Entrevista } \\
\text { presencial }\end{array}$ \\
\hline RR & $\begin{array}{l}\text { BVL da } \\
\text { Comunidade } \\
\text { Boca da Mata }\end{array}$ & $\begin{array}{l}\text { Associação } \\
\text { Expedição Vaga } \\
\text { Lume }\end{array}$ & $\begin{array}{c}\text { Membros da } \\
\text { comunidade; } \\
\text { professores e } \\
\text { jovens } \\
\text { voluntários }\end{array}$ & $\begin{array}{l}\text { Reuniões. } \\
\text { Decisões são } \\
\text { tomadas em } \\
\text { conjunto. }\end{array}$ & SME; UERR & $\begin{array}{l}\text { Entrevista } \\
\text { presencial }\end{array}$ \\
\hline $\mathrm{RR}$ & $\begin{array}{l}\text { BVL da } \\
\text { Comunidade } \\
\text { de Santa Rosa }\end{array}$ & $\begin{array}{l}\text { Associação } \\
\text { Expedição Vaga } \\
\text { Lume }\end{array}$ & $\begin{array}{c}\text { Membros da } \\
\text { comunidade; } \\
\text { professores e } \\
\text { jovens } \\
\text { voluntários }\end{array}$ & $\begin{array}{l}\text { Reuniões. } \\
\text { Decisões são } \\
\text { tomadas em } \\
\text { conjunto. }\end{array}$ & SME & $\begin{array}{l}\text { Entrevista } \\
\text { presencial }\end{array}$ \\
\hline SP & BC Zumaluma & $\begin{array}{l}\text { Grupo de jovens da } \\
\text { comunidade }\end{array}$ & $\begin{array}{l}\text { Jovens da } \\
\text { comunidade }\end{array}$ & $\begin{array}{l}\text { Reuniões. } \\
\text { Decisões são } \\
\text { tomadas em } \\
\text { conjunto. }\end{array}$ & $\begin{array}{l}\text { Prefeitura; } \\
\text { SME }\end{array}$ & $\begin{array}{l}\text { Entrevista } \\
\text { presencial }\end{array}$ \\
\hline $\mathrm{SP}$ & $\begin{array}{l}\text { Biblioteca } \\
\text { Confraria dos } \\
\text { Parceiros de } \\
\text { Guararema }\end{array}$ & MST & $\begin{array}{l}\text { Membros da } \\
\text { comunidade } \\
\text { ligados ao } \\
\text { movimento }\end{array}$ & $\begin{array}{l}\text { Reuniões. } \\
\text { Decisões são } \\
\text { tomadas em } \\
\text { conjunto. }\end{array}$ & Universidades & $\begin{array}{c}\text { Observação e } \\
\text { entrevista } \\
\text { presencial }\end{array}$ \\
\hline SP & $\begin{array}{l}\text { BC Prof. } \\
\text { Waldir de } \\
\text { Souza Lima }\end{array}$ & $\begin{array}{l}\text { Grupo de jovens da } \\
\text { comunidade }\end{array}$ & $\begin{array}{l}\text { Jovens da } \\
\text { comunidade }\end{array}$ & $\begin{array}{c}\text { Reuniões. } \\
\text { Decisões são } \\
\text { tomadas em } \\
\text { conjunto. }\end{array}$ & SMC; SME & $\begin{array}{l}\text { Entrevista } \\
\text { presencial }\end{array}$ \\
\hline SP & $\begin{array}{l}\text { Biblioteca } \\
\text { Solidária }\end{array}$ & $\begin{array}{c}\text { Bibliotecário Sidnei } \\
\text { P. Rosa }\end{array}$ & $\begin{array}{l}\text { O idealizador; } \\
\text { Jovens da } \\
\text { comunidade } \\
\text { contratados e } \\
\text { voluntários }\end{array}$ & $\begin{array}{c}\text { Não há } \\
\text { participação da } \\
\text { comunidade na } \\
\text { tomada de decisão }\end{array}$ & $\begin{array}{l}\text { General } \\
\text { Motors do } \\
\text { Brasil e } \\
\text { Petrobras }\end{array}$ & $\begin{array}{l}\text { Entrevista } \\
\text { presencial }\end{array}$ \\
\hline SP & BC Casulo & ICE & $\begin{array}{c}\text { Jovens da } \\
\text { comunidade } \\
\text { contratados } \\
\text { ou bolsistas } \\
\text { do ICE } \\
\end{array}$ & $\begin{array}{l}\text { Reuniões. } \\
\text { Decisões são } \\
\text { tomadas em } \\
\text { conjunto. }\end{array}$ & $\begin{array}{l}\text { Parcerias não } \\
\text { são } \\
\text { estabelecidas } \\
\text { pela biblioteca }\end{array}$ & $\begin{array}{l}\text { Entrevista } \\
\text { presencial }\end{array}$ \\
\hline SP & $\begin{array}{l}\text { BC Cultura } \\
\text { Jovem }\end{array}$ & $\begin{array}{c}\text { Sociedade Santo } \\
\text { Mártires e } \\
\text { Fundação Fé e } \\
\text { Alegria do Brasil }\end{array}$ & $\begin{array}{c}\text { Jovens da } \\
\text { comunidade } \\
\text { atuando de } \\
\text { maneira } \\
\text { voluntária. } \\
\end{array}$ & $\begin{array}{c}\text { Não há } \\
\text { mecanismos de } \\
\text { participação. }\end{array}$ & $\begin{array}{l}\text { Parcerias não } \\
\text { são } \\
\text { estabelecidas } \\
\text { pela biblioteca }\end{array}$ & $\begin{array}{l}\text { Entrevista } \\
\text { presencial }\end{array}$ \\
\hline SP & BC dos Garis & $\begin{array}{l}\text { ONG Educa São } \\
\text { Paulo sob a direção } \\
\text { de Devanir Amâncio }\end{array}$ & $\begin{array}{l}\text { O idealizador } \\
\text { e uma } \\
\text { funcionária } \\
\text { contratada } \\
\text { pela ONG }\end{array}$ & $\begin{array}{c}\text { Não há } \\
\text { mecanismos de } \\
\text { participação. }\end{array}$ & $\begin{array}{l}\text { Construfert } \\
\text { Ambiental e } \\
\text { PUC- SP }\end{array}$ & $\begin{array}{l}\text { Observação e } \\
\text { entrevista } \\
\text { presencial }\end{array}$ \\
\hline
\end{tabular}




\begin{tabular}{|c|c|c|c|c|c|c|}
\hline UF & BIBLIOTECA & IDEALIZADORES & $\begin{array}{c}\text { ATORES } \\
\text { PRINCIPAIS }\end{array}$ & $\begin{array}{c}\text { FORMAS } \\
\text { PARTICIPAÇÃO }\end{array}$ & PARCERIAS & $\begin{array}{l}\text { OBTENÇÃOO } \\
\text { DADOS }\end{array}$ \\
\hline SP & BC Heliópolis & $\begin{array}{c}\text { Projeto Identidade } \\
\text { Cultural - membros } \\
\text { internos e externos } \\
\text { à comunidade }\end{array}$ & $\begin{array}{l}\text { Jovens da } \\
\text { comunidade } \\
\text { contratados } \\
\text { pela UNAS. }\end{array}$ & $\begin{array}{c}\text { Não há } \\
\text { mecanismos de } \\
\text { participação. }\end{array}$ & $\begin{array}{c}\text { Escritório Ruy } \\
\text { Ohtake; } \\
\text { Banco } \\
\text { Panamericano }\end{array}$ & $\begin{array}{c}\text { Observação e } \\
\text { entrevista } \\
\text { presencial }\end{array}$ \\
\hline SP & $\begin{array}{l}\text { BC Ler é } \\
\text { Preciso da } \\
\text { Coopamare }\end{array}$ & Instituto Ecofuturo & $\begin{array}{l}\text { Membros da } \\
\text { comunidade }\end{array}$ & $\begin{array}{l}\text { Reuniões. } \\
\text { Decisões são } \\
\text { tomadas em } \\
\text { conjunto. }\end{array}$ & $\begin{array}{l}\text { Suzano Papel } \\
\text { e Celulose; } \\
\text { OAF }\end{array}$ & $\begin{array}{c}\text { Observação e } \\
\text { entrevista } \\
\text { presencial }\end{array}$ \\
\hline SP & $\begin{array}{l}\text { BC Livro-Pra- } \\
\text { Quê-Te-Quero }\end{array}$ & $\begin{array}{c}\text { Núcleo Cultural } \\
\text { Poder e Revolução }\end{array}$ & $\begin{array}{l}\text { Jovens da } \\
\text { comunidade }\end{array}$ & $\begin{array}{c}\text { Reuniões. } \\
\text { Decisões são } \\
\text { tomadas em } \\
\text { conjunto. }\end{array}$ & $\begin{array}{c}\text { IDEAC; } \\
\text { CDHU; } \\
\text { Santander }\end{array}$ & $\begin{array}{c}\text { Observação e } \\
\text { entrevista } \\
\text { presencial }\end{array}$ \\
\hline SP & $\begin{array}{l}\text { BC Prestes } \\
\text { Maia }\end{array}$ & $\begin{array}{c}\text { Casal de catadores } \\
\text { de lixo Severino e } \\
\text { Roberta }\end{array}$ & O casal & $\begin{array}{c}\text { Não há } \\
\text { mecanismos de } \\
\text { participação }\end{array}$ & $\begin{array}{c}\text { Não } \\
\text { informado }\end{array}$ & $\begin{array}{c}\text { Observação e } \\
\text { entrevista } \\
\text { presencial }\end{array}$ \\
\hline SP & $\begin{array}{l}\text { BC Solano } \\
\text { Trindade }\end{array}$ & $\begin{array}{l}\text { Núcleo Cultural } \\
\text { Força Ativa }\end{array}$ & $\begin{array}{l}\text { Jovens da } \\
\text { comunidade }\end{array}$ & $\begin{array}{c}\text { Reuniões. } \\
\text { Decisões são } \\
\text { tomadas em } \\
\text { conjunto. }\end{array}$ & $\begin{array}{c}\text { IDEAC; } \\
\text { CDHU; } \\
\text { Secretaria } \\
\text { Estadual de } \\
\text { Cultura } \\
\end{array}$ & $\begin{array}{c}\text { Observação e } \\
\text { entrevista } \\
\text { presencial }\end{array}$ \\
\hline
\end{tabular}




\section{ANEXO A \\ Trecho da letra do rap "Vamos ler um livro", de Betinho Biblioteca Comunitária Solano Trindade}

\section{Ei, ei, cara}

Mergulhe na história

Preste atenção no que eu vou dizer agora

Chega de ler besteira

Chega de babaquice

Procure se informar

Não seja o mestre da burrice

São tantos que falam merda

$E$ isso enjoa, é um tormento

Procure ler um livro

Pois é a máquina do tempo

Milhares de livros estão ao seu alcance

Mas você não quer saber

Sua idéia é fraca a todo instante

Você só fala besteira

Não tem auto-estima, meu irmão

Procure ler um livro, a fonte de informação

Mas você não quer saber

Só se liga em leituras pornográficas

Tipo revistas importadas, que vêm com loiras bem grandes na capa

Meu irmão, se esse tipo de coisa pra você é informação

Se Lina nas patricinhas que aparecem na Malhação

A televisão é uma droga que esconde a nossa história

Só tem coisa pra boy, quer ver os pretos pedindo esmola

[...]

Agora eu quero ouvir, todo mundo comigo:

Vamos ler um livro, vamos ler um livro

Povo da periferia, vamos ler um livro

Eu quero ouvir a maioria, vamos ler um livro

Comuna Força Ativa, pois não queremos ser os tais

Pois sabemos que a boa leitura ensina até demais

Portanto, meu amigo, procure se informar

Pois do jeito que está, não, não pode ficar

São tantos sem cultura, sem conhecimento pra trocar

A leitura é importante, o livro é arma fatal

Que acaba com a ignorância, deixa sua mente legal

[...]

Estou cansado de ouvir esses caras falarem besteira

Chega de letra babaca, o hip-hop não é brincadeira

Vamos mostrar a história que a escola não mostra hoje em dia

Em forma de rap, mostrá-la para o povo, aos trabalhadores na periferia

Vamos ler um livro, vamos ler um livro

(LOPES, 2003, p.31) 


\section{ANEXO B \\ Trecho de rap apresentado por Weber Lopes e Fernandinha da Biblioteca Comunitária Solano Trindade}

Entro na biblioteca e começo a observar

Quais são os tipos de leitura que as pessoas vão procurar

A maioria é trabalho escolar

Nas férias vem muito pouco

A maioria não cola

Mas aí

Somos persistentes

Temos a primeira biblioteca comunitária

Montada em Cidade Tiradentes

Com mais de 3.000 consulentes

Além de emprestar livros temos formação

De como entender a sociedade visando a transformação

Como conseguir viver numa sociedade?

Salve, salve, vou me apresentar

Meu nome é Fernanda e sou mediadora de leitura

Faço parte do Núcleo Cultural Força Ativa

Do Arame Farpado e dos Fantasmas Vermelhos

Companheiros e companheiras

Para nos identificar é muito fácil

Pois estamos sempre com um livro embaixo do braço

(ENCONTRO, 2006) 


\section{ANEXO C \\ Teste de interesse comunitário e teste de organização comunitária Associação Vaga Lume}

\section{1- TESTE DE INTERESSE COMUNITÁRIO}

ATENÇÃO: Assinale apenas as afirmações verdadeiras:

Algum morador da comunidade procurou a equipe de multiplicação.

O professor da comunidade que manifestou interesse mora ou trabalha há muito tempo na comunidade.

A comunidade já tentou desenvolver outros projetos de leitura.

A comunidade conhece/tem contato com outra biblioteca comunitária da Expedição Vaga Lume.

$\square$ A mediação de leitura já acontece na comunidade.

$\square$ Moradores da comunidade vêm procurando parcerias para melhorias.

Moradores da comunidade procuram envolver a juventude nas atividades comunitárias.

$\square$ Moradores da comunidade já procuraram ą prefeitura buscando melhorias para a educação.

Os moradores da comunidade estão dispostos a trabalhar voluntariamente na biblioteca Vaga Lume.

$\square$ Os moradores da comunidade estão dispostos a construir ou adaptar um espaço exclusivo para a biblioteca Vaga Lume.

Agora conte o número de respostas assinaladas e confira com os resultados

Obs.: Este teste não é científico nem definitivo. Foi elaborado com base na experiência da Expedição Vaga Lume. 


\section{2- TESTE DE ORGANIZAÇÃO COMUNITÁRIA}

\section{ATENÇÃO: Assinale apenas as afirmações verdadeiras:}

Tem o costume de trabalhar em mutirão.

A comunidade realiza ações em conjunto com outras comunidades próximas.

A comunidade se organiza para resolver problemas coletivamente.

É difícil as pessoas da comunidade se mudarem para outras comunidades, cidades ou para a sede do município.

A comunidade já desenvolveu algum projeto com parceria externa.

Os professores da escola são moradores da comunidade.

$\square$ Os professores trabalham há muito tempo na escola, pois não há muita rotatividade.

$\square$ Na comunidade há parteiras, curandeiros ou pajé.

A comunidade possui uma rádio comunitária.

Há na comunidade um centro comunitário ativo onde acontecem festas, reuniões, bingo, ou outras atividades.

$\square$ A comunidade possui uma ou mais associações comunitárias.

$\square$ Existe algum grupo cultural (dança, música, teatro, etc) na comunidade.

$\square$ os moradores integram algum grupo esportivo (time de futebol, capoeira, etc.).

$\square$ Há na comunidade um grupo coordenado e composto só por jovens.

$\square$ Há uma organização das mulheres.

$\square$ Os trabalhadores estão organizados coletivamente (em alguma cooperativa local, ou outra forma de organização).

$\square$ A comunidade possui bens coletivos (que não têm um só dono), tais como um barco, uma casa de farinha, televisão, carro, aparelho de som ou outros.

$\square$ A comunidade tem uma liderança definida (ex. Tuxaua, cacique, presidente da comunidade, etc.).

A comunidade tem uma liderança atuante jovem.

Educação e Cultura são focos de atuação das atuais lideranças.

$\square$ o relacionamento entre os comunitários é bom, as pessoas se ajudam, se gostam, se protegem.

Agora conte o número de respostas assinaladas e confira com os resultados

Obs.: Este teste não é científico nem definitivo. Foi elaborado com base na experiência da Expedição Vaga Lume. 


\section{CONFIRA OS RESULTADOS:}

\section{1 - TESTE DE INTERESSE COMUNITÁRIO}

0 a 3 pontos - Baixo

Você tem certeza que esta comunidade quer uma biblioteca?

4 a 7 pontos - Médio

Eles parecem querer, lembre-se de verificar a FINALIDADE, ou seja, para quê é que eles querem esta Biblioteca?

8 a 10 pontos - Alto

Eles têm muito interesse, vale a pena investir!

\section{2 - TESTE DE ORGANIZAÇÃO COMUNITÁRIA}

0 a 6 pontos - Baixa

Baixa organização, provavelmente você terá muito trabalho para fazer a biblioteca funcionar com a participação da comunidade

7 a 14 pontos - Média

Parece que esta comunidade está preparada para receber uma Biblioteca Vaga Lume.

Quanto maior o número de pontos, mais facilidade você terá para desenvolver seu trabalho.

15 a 20 pontos - Alta

Esta comunidade terá mais facilidade para cuidar da biblioteca.

Obs.: Este teste não é científico nem definitivo. Foi elaborado com base na experiência da Expedição Vaga Lume. 


\section{ANEXO D \\ Trecho de letra de rap do CD Rimar para a Prevenção Núcleo Cultural Força Ativa}

Faixa 2 - Ego

Vozes: Tito e Akin / Baixo: Renato MC / Programação, Guitarra e Teclado

Refrão

Cada fio do meu cabelo é um livro que já li

Para agir tem que falar

Para falar tem que ouvir

Para ouvir tem que ler

Para ler tem que agir

Faixa 3 - Viagem na idéia

Vozes: Weber e Brehmer / Programação, baixo Synth e Teclado: Fabio Pinc

Viagem na idéia, na nossa batida

Aqui não tem seringa,

A gente compartilha informação politização

Essa é a saída Força Ativa te alerta

Auto se eduque e se previna

Ponha a camisinha na sua vida

Com 16 se empolgou pra 19 transformar

Você não acreditava, confiou, transou preservativo não usou

As propagandas na TV

Não assimilou

Pois bem, então continuou, saiu com várias, deu mó vacilo

Olha o resultado do machismo

[...]

Procure se organizar

Idéias positivas múltiplas, múltiplas, múltiplas

Para os parceiros e as parceiras, uma vida sexual iniciar

Sem susto, seguro, sem medo

Com camisinha Mem o vírus pegará

Se estiver contaminado não transmitirá

Gonorréia, sífilis nem pensar

Sexo seguro, prazeroso em primeiro lugar

Núcleo Cultural Força Ativa

Idéias positivas acabam de passar

Camisinha na gaveta é na bolsa, na carteira

Nem pensar

Qualidade, validade, selo do IMMETRO e o arzinho é só verificar

Os livros sobre $o$ assunto têm de monte

Tem dúvida é só consultar, pesquisar se informar

Tem que se politizar até na hora de transar

[...] 